\title{
The regulation of factor $\mathrm{Xa}$ generation at tissue factor bearing surfaces
}

Citation for published version (APA):

Salemink, I. (1999). The regulation of factor Xa generation at tissue factor bearing surfaces. [Doctoral Thesis, Maastricht University]. Datawyse / Universitaire Pers Maastricht.

https://doi.org/10.26481/dis.20000218is

Document status and date:

Published: 01/01/1999

DOI:

$10.26481 /$ dis.20000218is

Document Version:

Publisher's PDF, also known as Version of record

\section{Please check the document version of this publication:}

- A submitted manuscript is the version of the article upon submission and before peer-review. There can be important differences between the submitted version and the official published version of record.

People interested in the research are advised to contact the author for the final version of the publication, or visit the DOI to the publisher's website.

- The final author version and the galley proof are versions of the publication after peer review.

- The final published version features the final layout of the paper including the volume, issue and page numbers.

Link to publication

\footnotetext{
General rights rights.

- You may freely distribute the URL identifying the publication in the public portal. please follow below link for the End User Agreement:

www.umlib.nl/taverne-license

Take down policy

If you believe that this document breaches copyright please contact us at:

repository@maastrichtuniversity.nl

providing details and we will investigate your claim.
}

Copyright and moral rights for the publications made accessible in the public portal are retained by the authors and/or other copyright owners and it is a condition of accessing publications that users recognise and abide by the legal requirements associated with these

- Users may download and print one copy of any publication from the public portal for the purpose of private study or research.

- You may not further distribute the material or use it for any profit-making activity or commercial gain

If the publication is distributed under the terms of Article $25 \mathrm{fa}$ of the Dutch Copyright Act, indicated by the "Taverne" license above, 
The Regulation of Factor Xa Generation at Tissue Factor Bearing Surfaces 
Cover: Irene Salemink

Printed by: Datawyse I Universitaire Pers Maastricht

ISBN 9052782725

(c) Irene Salemink, Maastricht 1999 


\title{
The Regulation of Factor Xa Generation at Tissue Factor Bearing Surfaces
}

\author{
PROEFSCHRIFT \\ ter verkrijging van de graad van doctor \\ aan de Universiteit Maastricht, \\ op gezag van de Rector Magnificus, \\ Prof. dr. A.C. Nieuwenhujizen Kruseman \\ volgens het besluit van het College van Decamen, \\ in het openbaar te verdedigen op \\ vrijdag 18 februari 2000 om 14.00 uur \\ door \\ Irene Salemink
}

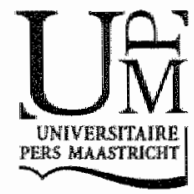


Promotor:

Prof.dr. H.C. Hemker

Co-promotores:

Dr. T. Lindhout

Dr. G.M. Willems

Beoordelingscommissie:

Prof.dr. W.Th. Hermens (voorzitter)

Prof.dr. L.A. Aarden (Universiteit van Amsterdam)

Prof.dr. C.A. Bruggeman

Prof.dr. M.J.A.P. Daemen

Prof.dr. D.A. Lane (Charing Cross College London, United Kingdom)

Financial support by the Netherlands Heart Foundation and by the Netherlands Organization for Scientific Research (NWO) for the publication of this thesis is gratefully acknowledged. 
"Art is a lie that enables us to intuit the truth, or at least as much of the truth as we are allowed to understand"

Pablo Picasso 



\section{Contents}

\section{Chapter 1}

General Introduction

\section{Chapter 2}

Transient High Affinity Binding of Tissue Factor Pathway Inhibitor:Factor Xa

Complexes to Negatively Charged Phospholipid Membranes

\section{Chapter 3}

Factor Xa Cleavage of Tissue Factor Pathway Inhibitor is Associated with Loss

of Anticoagulant Activity

\section{Chapter 4}

Inhibition of Tissue Factor:Factor Vlla Catalyzed Factor X Activation by

Factor Xa:Tissue Factor Pathway Inhibitor: A Rotating Disc Study on the Effect of Phospholipid Membrane Composition

\section{Chapter 5}

Tissue Factor:Factor VIlla Catalyzed Factor X Activation and Its Inhibition by Factor Xa:Tissue Factor Pathway Inhibitor at Human Embryonic Lung Fibroblasts Adhered to a Rotating Disc

\section{Chapter 6}

Antibodies to $\beta_{z}$-Glycoprotein I from Patients with Anti-Phospholipidl

Syndrome Suppress the inhibitory Activity of Tissue Factor Pathway Inhibitor

Chapter 7

General Discussion

Nederlandse Samenvatting

Dankwoord 



\title{
Chapter 1
}

\author{
General Introduction
}

\section{Preface}

Higher organisms are provided with a vascular system that serves to channel the distribution of nutrients and oxygen to tissues and to remove the waste products. Maintenance of the integrity of this vasculature is of vital interest because a vascular injury leading to the loss of significant amounts of blood is incompatible with survival. Therefore the organisms are provided with a haemostatic system that rapidly reacts on vascular damage and arrests bleeding by recruiting the appropriate cells and enzymes. To guarantee such a fast response that at the same time is restricted to the site of damage without propagating through the vascular system, requires a very strict control of the haemostatic system.

To outline the objective of this thesis, the general process of blood coagulation will be considered in the next paragraphs with the emphasis on the tissue factor dependent coagulation pathway and the regulation thereof. 


\section{The Procoagulant Pathways}

The process of blood coagulation, initiated after vessel injury, is composed of wo major events. Firstly, blood platelets adhere to the damaged vessel wall, which results in platelet aggregation and the subsequent formation of a primary haemostatic plug. Secondly, due to the activation of the coagulation cascade (1), a fibrin network is formed that stabilizes the primary haemostatic plug. As discussed later, the presence of the phospholipid surfaces containing phosphatidylserine (PS), an anionic phospholipid, is essential for promoting the enzymatic reactions of the coagulation cascade. These PS containing membrane surfaces are provided by blood platelets, in addition to their participation in plug formation. After adherence to the damaged vessel wall (i.e. collagen), blood platelets become activated and consequently translocate PS from the inner leaflet (2) to the outer leaflet of their plasma membirane.

In addition to response to trauma, caused by injury, surgery or interventions like coronary angioplasty, directional coronary atherectomy, and coronary artery stenting $(3-5)$, the haemostatic process can also become activated by pathological conditions like sepsis $(6,7)$ and atherosclerosis $(8-10)$. For instance plaque rupture in atherosclerotic vessels, is often associated with acute arterial thrombosis whereby a thrombus (blood clot containing platelets and fibrin) causes the complete vascular occlusion of the affected vessel. Accurate antithrombotic therapy is thus essential under these circumstances to prevent organ failure.

In 1964, the haemostatic response was characterized as a cascade (11) or waterfall (12) of enzymatic reactions in which plasma pro-enzymes (like coagulation factors $I I, I X, X$ and $X \mid)$ are converted via limited proteolysis to their active forms (denoted by a small ' $a$ ' added to the roman number). In this classical model these activation reactions are grouped into two pathways, the intrinsic and the extrinsic pathway (Fig. 1), that converge at the activation of factor $X(F X)$, after which the generation of thrombin proceeds through a single, common, pathway. The intrinsic pathway is activated by exogenous negatively charged surfaces in combined action with kallikrein and high molecular weight kininogen (HMWK) and the series of enzymatic reactions starts with the formation of FXIla (13). FXIla activates $\mathrm{FXI}$, which in turn will activate FIX. FIXa then forms with the activated non-enzymatic cofactor FVIIla, in the presence of $\mathrm{Ca}^{2+}$ ions and a negatively charged phospholipid surface, the intrinsic tenase complex that very efficiently activates $F X$. The initiation of the extrinsic pathway, on the other hand, takes place when after vascular injury (14-16) tissue factor (TF), a membrane protein present in the adventitia, becomes exposed to the flowing blood. Circulating FVII binds to TF and consequently is activated. The TF.FVlla complex, also called the extrinsic tenase complex, in tum activates FX. In the common pathway, the generated FXa, together with the non- 
enzymatic cofactor FVa, participates in the formation of the somcalled prothrombinase complex that, like the intrinsic and extrinsic tenase, is assembled at negatively charged phospholipid surfaces. Prothrombinase then converts prothrombin to thrombin, which finally results in the conversion of soluble fibrinogen into insoluble fibrin polymers.

Intrinsic pathway

Extrinsic pathway

negatively charged surface

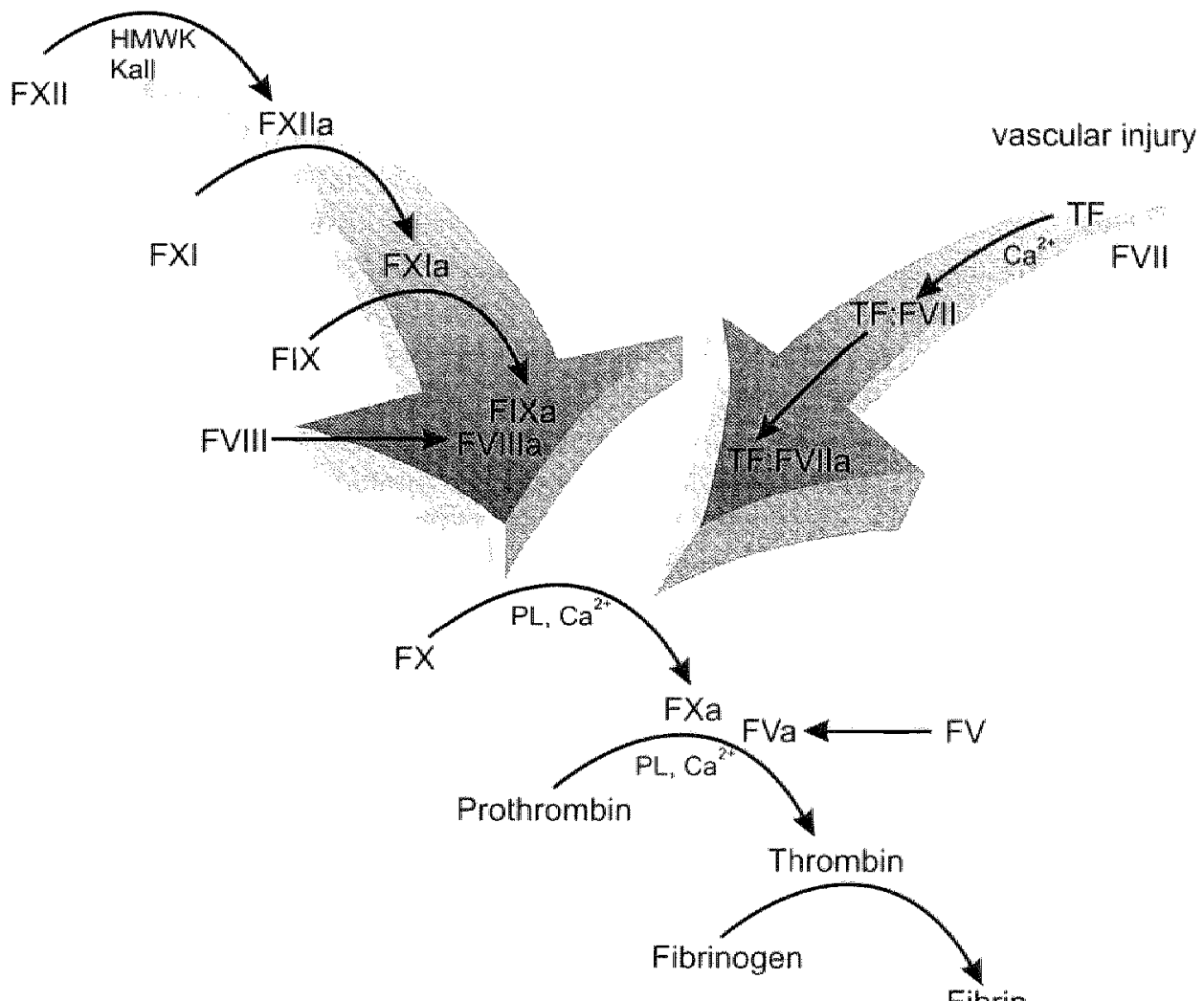

Figure 1. Schematic overview of the classilcal coagulation cascade, divided in the intrinsic and extrinsic pathway. PL, phospholipid; HMWK, high molecular weight kininogen; Kall, kallikrein. 
However, strict separation of the known coagulation factors into the intrinsic and extrinsic pathway does not accurately describe the clinical observations made regarding bleeding disorders. Individuals lacking one of the "contact" factors in the intrinsic pathway (prekallikrein, high molecular weight kininogen and FXII) are asymptomatic (17-19). In contrast, individuals lacking FVIII or FIX (hemophilia A or B respectively) suffer from a severe bleeding diathesis $(20,21)$. Also people with a FXI deficiency do have episodes of abnormal bleeding but these are only significant during surgery (22). These observations seemed rather paradoxical in the light of an intact extrinsic pathway. The notion that FIX activation by TF:FVIla forms a link between the two pathways (23) and the rediscovery and characterization of an endogenous inhibitor of TF-induced coagulation $(24,25)$, tissue factor pathway inhibitor (TFPI), led to a reformulation of the coagulation cascade $(26,27)$.

In the revised model (Fig. 2), binding of FVII to exposed TF is the only trigger in vivo for the initiation of the blood coagulation and the contact factors are not required. The TF:FVIla complex generates FXa and FIXa but the inhibitory effect of TFPI becomes soon manifest and prevents further production of FXa and FIXa via this route. The feedback activation of FVIII and FXI by thrombin, however, results in an ongoing generation of FIXa:FVIlla complex, which in turn activates additional FX, leading to the amplification of the coagulation process that is critical for a normal haemostatic reaction. Accordingly, haemophiliacs lacking FVIII or FIX bleed because the initial FXa generated by TF:FVIla is insufficient to sustain haemostasis. As shown in the revised model, the haemostatic process does not end with the initial generation of FXa and thrombin but thrombin mediated activation of FXI, FVIII and FV results in a positive feedback on the coagulation cascade $(15,28,29)$. Another procoagulant activity of thrombin is platelet activation, ensuring the formation of more procoagulant membrane surface for the reactions to take place.

\section{The Anticoagulant Pathways}

The anticoagulant pathways prevent the haemostatic system from tipping towards excessive blood coagulation and limit the coagulation process to the site of vascular damage. The action of natural anticoagulants can be divided in various distinct mechanisms. Inhibitors like antithrombin (AT), tissue factor pathway inhibitor (TFPI) and heparin cofactor $\|$ ( $\mathrm{HCl}$ ) are constitutively present in plasma and act as pseudo substrates. That is, these inhibitors interact with the active site of procoagulant enzymes to form stable enzyme-inhibitor complexes in which the enzyme has lost its catalytic activity. $\alpha 2-$ Macroglubulin $(\alpha 2 M)$ is also a plasma inhibitor but inactivates the enzyme by covalent binding to the coagulation factor. 
The third mechanism of action involves a protease (activated protein C) that catalyses the proteolytic inactivation of the colactors FVa and FVIIIa.

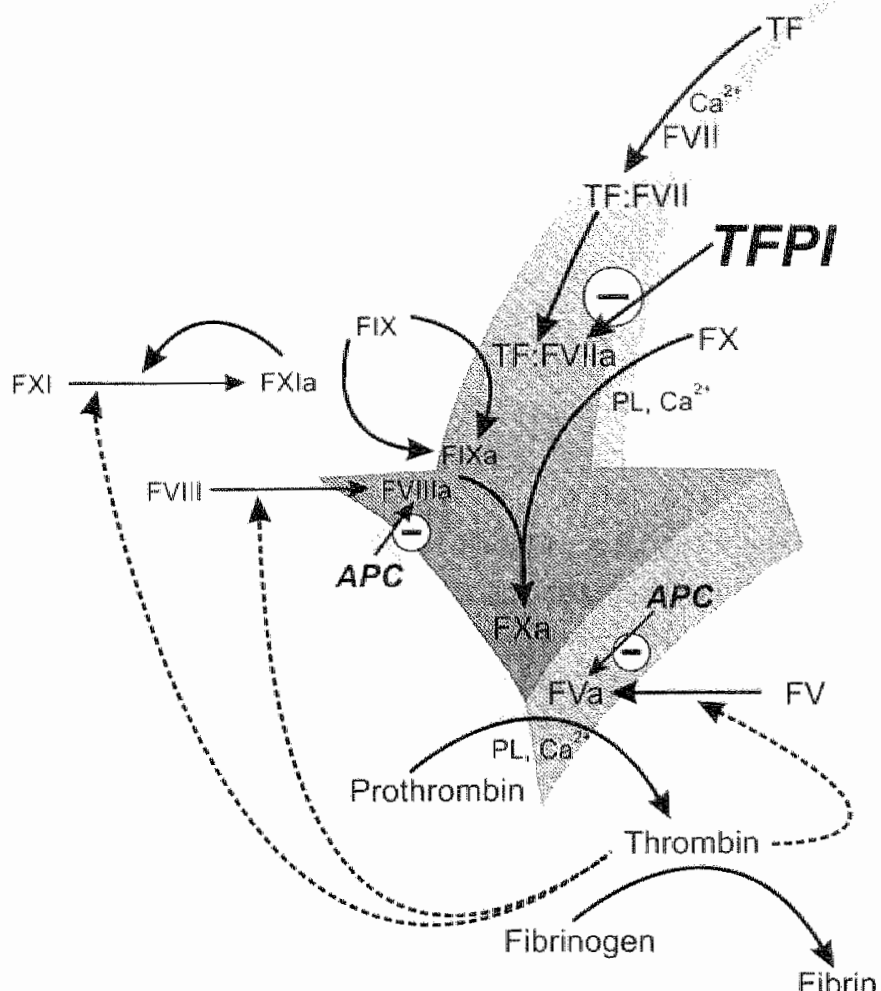

Figure 2. The revised model of coagulation. FVII binds to TF at a site of vascular injury and becomes activated. FXa and FIXa are generated in limited quantities before TF-FVlla is inhibited by TFPI. The generation of FXa is then amplified through the action of FIXa:FVilla whereby FIXa is activated by $\mathbb{F X l a}$ that in turn has been produced by thrombirn or FXIa. The dotted lines indicate the positive feedback by thrombin. $\ominus$ indicates inhibition by activated protein C (APC) and tissue factor pathway inhibitor (TFPI).

\section{Antithrombin and Tissue Factor Pathway Inhibitor}

AT is the major plasma inhibitor of coagulation proteases and inhibits thrombin, FXa, FXla, and FXIla, of which thrombin and FXa are considered to be the relevant targets in vivo $(30,31)$. AT is a member of the protein superfamily of serine protease inhibitors (serpins) and circulates in plasma at a concentration of 5 
$\mu M$. Like all other serpins, AT exerts its inhibitory action by binding irreversibly to the active site of the enzyme (32). The inhibitory activity of AT is potentiated by heparin $(30,31)$. It was found that AT/heparin also inhibits, although slowly, FVlla bound to TF $(33,34)$. The physiological inhibitor of TF:FVlla catalytic activity, however, is tissue factor pathway inhibitor $(25,27)$ whose inhibitory action proceeds as a twostep mechanism. TFPI first binds and inhibits FXa and subsequently forms a quaternary complex with TF.FVlla in which the FVIla enzymatic activity is completely inhibited.

\section{a2 Macroglobulin}

In addition to AT, $\alpha 2 \mathrm{M}$ is the second major inhibitor of thrombin in blood. $\alpha 2 \mathrm{M}$ furthermore inhibits other serine proteases like FV, FIX FX etc. After binding of the protease to $\alpha 2 \mathrm{M}$ and the subsequent hydrolysis of a bond in the bait-region of $\alpha 2 \mathrm{M}$ a conformational change in $\alpha .2 \mathrm{M}$ is induced and the protease is irreversibly entrapped (35). Subsequently, the $\alpha 2 \mathrm{M}$-enzyme complex is cleared from the circulation by a receptor mediated cellular internalization. Although $\alpha 2 \mathrm{M}$ does not bind to the active site of thrombin, the $\alpha 2 \mathrm{M}$-thrombin complex looses its inhibitory activity towards large ( $>30 \mathrm{kDa}$ ) protein substrates (36). $\alpha 2 \mathrm{M}$ is abundantly present in plasma at a concentration of $2.9 \mu \mathrm{M}$.

\section{Protein C Pathway}

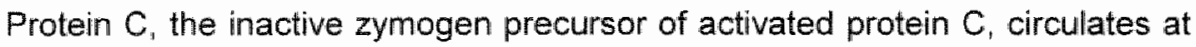
a plasma concentration of $50-80 \mathrm{nM}$. Protein $\mathrm{C}$ is activated by thrombin, a reaction which is dramatically accelerated when thrombin is bound to thrombomodulin ( 37 , 38). Thrombomodulin (TM) is an integral membrane protein present on the vascular surface of endothelial cells (39). Activated protein C (APC) proteolytically inactivates FV(a) and FVIII(a), by cleaving multiple peptide bonds (40). The inhibitory action of APC depends on the presence of $\mathrm{Ca}^{2+}$ and anionic phospholipids and is enhanced by protein $S$, which serves as a cofactor for APC. The cofactor activity of protein S is abolished upon binding to C4b-binding protein (39), while APC is inhibited by protease inhibitors like protein $C$ inhibitor, $\alpha 2 \mathrm{M}$ and $\alpha 1$-antitrypsin (41-43). Whereas deficiencies in procoagulant factors result in bleeding disorders, quantitative and qualitative deficiencies of protein $C$ and protein $S$ result in increased risk of thrombosis (44). A hereditary disorder related to the protein $C$ pathway $(45,46)$ further was found to be caused by that a mutation in the FV gene ( $F V_{\text {Leiden }}$ ) producing a $\mathrm{FV}(\mathrm{a})$ that is resistant to cleavage at amino acid position 506 by protein C $(47-50)$. 


\section{The Tissue Factor Pathway and Its Regulation}

Because the TF-dependent pathway and its regulation are the topics of this thesis, the components and regulatory mechanisms that are involved will be discussed in more detail in this section.

\section{Tissue Factor}

Physiology. Immunohistochemical localization (51) demonstrated that the cellular expression of TF is highly selective, that is. TF is found at tissue bartiers between the body and environment and at boundaries between organs. Cells normally in contact with plasma (blood cells and the endothelium) are devoid of TF although endothelial cells and monocytes can be stimulated to transiently express TF. Among known stimuli are cytokines (TNF $\alpha$ ), Interleukin-1 (52), endotoxin (53), thrombin $(54,55)$ and lipopolysaccharides (56). These agents are released in diseases accompanied with extensive inflammation, local coagulation and/or systemic thrombotic propensity (e.g. disseminated intravascular coagulation, cancer, atherosclerosis and sepsis). In normal arteries. TF is mainly found in the adventitia, at fibroblasts that constitutively express TF. However, TF can be rapidly induced in smooth muscle cells (SMC) of the media by thrombin, epidermal growth factor, angiotensin II and platelet derived growth factor (57). Human atherosclerotic plaques also contain TF-antigen (58-62), which is found within macrophages, SMC, endothelial cells, extracellular matrix and most abundantly in the acellular lipid rich core $(10,63-65)$.

Structural Characteristics of TF. TF is a transmembrane glycoprotein with a molecular weight of 42 to $47 \mathrm{kDa}$ depending on the extent of glycosylation by $\mathrm{N}$ linked oligosaccharides (66). Glycosyllation, however, is not required for its function (67). TF has a three-domain structure (Fig. 3) comprising an extra-cellular domain (residues 1-219), a hydrophobic membrane-spanning domain (residues 220-242) and a cytoplasmic tail (residues $243-263$ ). The Cys ${ }^{245}$ residue in the cytoplasmic tail is coupled to stearate or palmitate. which may help to anchor TF into the plasma membrane (68). Sequence analysis indicated that the TF extra-cellular domain resembles the type of folding common to the cytokine growth factor family $(14,69)$. This domain consists of two fibronectin type III-like modules (TF-1 and TF-2) (70, 71), which form a $V$-shaped trough with an interdomain angle of $120^{\circ}$. The FVIlla binding residues of TF are principally located in this through (71-73). Furthermore. three Trp-Lys-Ser sequences are present, which may provide a particular secondary or tertiary structure required for high affinity binding of FVII (74). Alt the boundary between membrane and cytoplasmic tail a cluster of four basic amino acids is 
present which is suggested to direct the membrane insertion in the $\mathrm{N}$-terminusextra-cellular orientation (75) through electrostatic interactions.

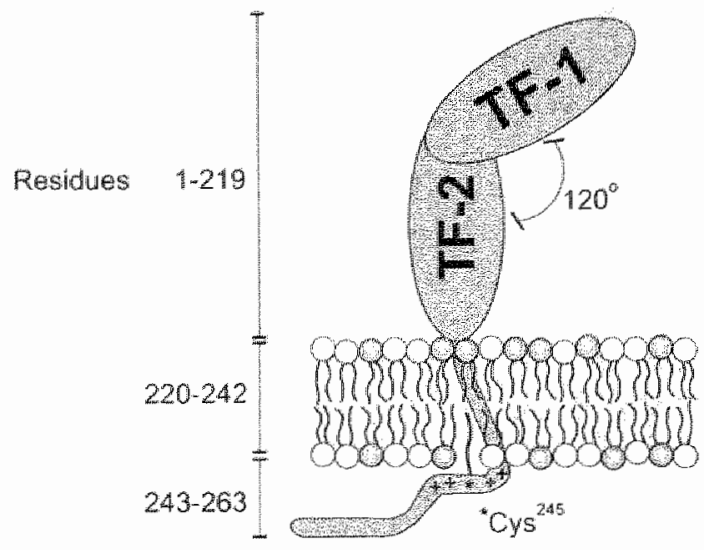

Figure 3. Schematic representation of the TF molecule.

\section{Factor VII}

Physiology. FVII circulates in plasma as a single chain zymogen, in a concentration of $10 \mathrm{nM}(76)$. Human FVII is synthesized predominantly by the liver (76) but stimulated monocytes and macrophages may provide a source of FVIImRNA as well (77). Of all coagulation factors, FVII has the shortest half-life (5 hours) (78). The half-life of 2.5 hours of activated FVII, however, is rather long compared to other activated coagulation factors $(79,80)$. Increased levels of FVII (both antigen and coagulant activity) have been reported in patients with myocardial infarction (81) and in patients with an increased risk of cardiovascullar disease (82). Acquired deficiency of FVII is usually due to liver diseases, oral anticoagulant therapy or vitamin-K deficiency (55).

Structural Characteristics of FVII(a). FVli(a) (Fig. 4) has a molecular weight of $\sim 50 \mathrm{kDa}$ depending on both $\mathrm{N}$ - and O-glycosylation. FVII(a), like FIX, FX, prothrombin and protein $\mathrm{C}$ is a vitamin $\mathrm{K}$ dependent coagulation factor, containing $10 \gamma$-Carboxyglutamic acid (Gla) residues near its $\mathrm{N}$-terminus (Fig. 4). The Gla residues form a highly negatively charged surface and mediate the binding of $\mathrm{Ca}^{24}$. In FVIII(a), $7 \mathrm{Ca}^{2+}$ ions are coordinated by the Gla residues and consequently a conformational change of the Gla domain is induced $(73,83-85)$. Located next to the Gla domain is the aromatic stack, a short hydrophobic stretch, followed by two 
epidermal growth factor (EGF)-like domains (86). The last module is the (Arg specific) serine protease domain, which shows homology with trypsin and chymotrypsin (87).

The zymogen FVII (single chain) becomes activated when the FVII molecule is hydrolyzed at the peptide bond between $\mathrm{Arg}^{152}$ and $11 \mathrm{e}^{153}$. In the resulting two-chain molecule (FVIla) the light chain (Gla and two EGF like domains) and a heavy chain (protease domain) are held together by a single disulfide bond (88) between $\mathrm{Cys}^{135}$ and $\mathrm{Cys}^{262}$. Known activators of FVII in vitro are thrombin (89), FXlla (90), FXa and FIXa, all in the presence of $\mathrm{Ca}^{2+}$ and phospholipids (89). Auto-activation of FVII bound to TF by TF:FVlla has also been described (91). In contrast to the other activation reactions, auto-activation proceeds at the greatest rate when TF is surrounded by neutral phospholipids (92). Of all these candidates, FXa appears to be the most potent activator of FVII in wivo and, in addition. TF accelerates the activation of FVII $(93,94)$.

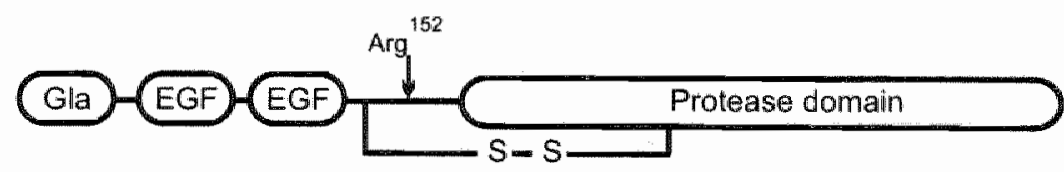

Figure 4. Schematic representation of the FVII(a) molecule.

\section{The Tissue Factor-Factor VII(a) Complex}

FVlla by itself has only little proteolytic activity. Full functional activity requires binding to TF and the presence of $\mathrm{Ca}^{2+}$ and anionic phospholipids $(16,95,96)$. The dramatic increase in intrinsic catalytic activity upon binding to TF $(97)$ is induced by a conformational change in FVlla which reduces its mobility (98) and positions the catalytic domain with respect to the phospholipid surface (99). The most important effect, however, is the restructuring of the active site region that in FVIla, even after proteolytic activation, is still zymogen-like. That is, the salt bridge between the newly formed $\mathrm{N}$-terminus at $11 \mathrm{e}^{453}$ and the carboxyl group of $\mathrm{Asp}^{343}$ is not completely formed unless FVIla binds to TF $(100,101)$. This salt bridge is essential for the catalytic activity of FVila because it stabilizes the active conformational state of the protease domain.

TF binds the pro-enzyme, FVII, and the activated protease, FVIla, with near equal affinity in a $1: 1$ stoïchiometry $(102,103)$. The reported dissociation constants vary enormously, between $10^{-12}$ and $10^{-8} \mathrm{M}$, depending on the conditions and methods used (104). Mutational- (105) and crystal-structure analysis (73) revealed 
that binding of FVlla to TF occurs via an extensive interface between these proteins of approximately $1800 \mathrm{~A}^{2}$. Three major contact sites can be distinguished (73) as schematically shown in Fig. 5. The first contact site is between FVlla-Gla domain and the TF.2 domain. This interaction is mainly hydrophobic and involves mostly residues of the hydrophobic stack. The second contact site is between FVIla-EGF-1 and TF-1TFF-2 and the third is between FVIla-EGF -2/protease domain and the top of the TF-1 domain. The presence of anionic phospholipids enhances the binding of FVlla to TF, which is reflected in the dissociation constant that decreases from $3 \mathrm{nM}$ to $50 \mathrm{pM}$ (106). A plausible explanation for this stimulating effect of PS on FVlla binding to TF could be that $\mathrm{Ca}^{2+}$ mediates the binding of the FVIla-Gla domain to anionic phospholipids. It should, however, be noted that compared to other vitamin $K$ dependent serine proteases IFVIla binds relatively weakly to anionic phospholipid surfaces (107).

The conformation of TF alone $(70,71)$ is almost identical to that of TF in complex with FVlla. Therefore it is plausible that TF provides a rigid scaffold which positions the FVlla catalytic domain, facilitating substrate recognition and proteolytic activation. Furthermore it was shown that when bound to TF, FVIla wraps around its cofactor and adopts an extended conformation $(73,99)$. As a result, the active site of FVlla is positioned $82 \AA$ above the membrane. The active sites of FX and FIX also are located far above the membrane (at least $60 \mathrm{~A}$ ), suggesting that the enzymatic reactions occur at a considerable distance from the phospholipid surface.

\section{Factor $X$ and Its Hydrolysis by TF:FVIla}

FX circulates in plasma at a concentration of $160 \mathrm{nM}$. It is synthesized by hepatocytes and has a molecular weight of $58 \mathrm{kDa}$. This vitamin $\mathrm{K}$ dependent proenzyme contains 12 Gla residues in the $\mathrm{N}$-terminus. Among the coagulation zymogens $F X$ is rather unique in that it is recovered from plasma as a two-chain disulfide-bridged protein (108) (Fig. 6). The conversion of $F X$ to the active serine protease FXa requires cleavage of the single peptide bond at Arg ${ }^{194}$ (109) located at the heavy chain. The attachment of the light and heavy chain via a disulfide bridge ensures that FXa remains bound to the anionic phospholipid surface via the Gladomain.

Although both FIX and FX can be activated by TF:FVlla (110), most studies have found that $F X$ is the preferred substrate $(110,111)$. Efficient TF:FVIla mediated proteolysis of FX not only depends upon changes in the active site (environment) of FVIla but additional interactions between substrate and TF:FVIla appear to be involved. 


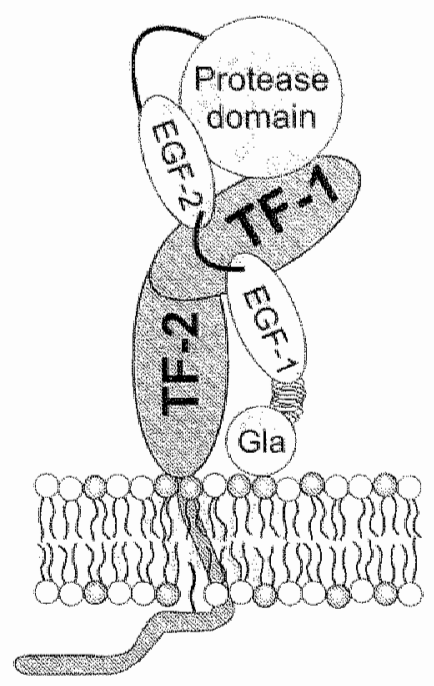

Figure 5. Schematic representation of the TF:FVIla complex. $Q$ indicates anhionic phospholipid.

The TF-2 domain was shown to be an important FX contact site (112-114) in which this region interacts with the Gla-domain of FX. Furthermore it was proposed that also the FVIla-Gla domain participates in the proteolysis of FIX and FX (114-116).

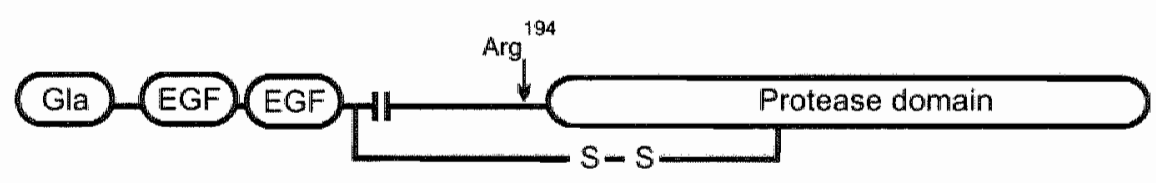

Figure 6 . Schematic representation of the $\mathrm{FX}(\mathrm{a})$ molecule.

Importance of Phospholipids for the Assembly of Macromolecular Substrate

As described, the anionic phospholipid phosphatidylserine (PS) increases FVIla binding to TF $(97,103)$. The presence of PS enhances the activation of FIX and FX (117-119). Based upon kinetic analysis it has been suggested that phospholipid bound FX is the preferred substrate for TF:FVIla (118). Two proposed mechanisms for enhancement by PS of TF:FVlla-mediated FX activation are 1) PS 
promotes membrane binding of the substrate in the vicinity of TF:FVIla, and 2) FVlla bound to TF embedded in a phospholipid membrane optimally aligns the FVlla active site with the scissile bonds of PS bound substrates. Additionally, it was hypothesized $(102,103,120)$ that anionic phospholipid promotes formation of dimeric or multimeric complexes of TF thereby altering the binding of FVIla both qualitatively and quantitatively, i.e. positive cooperativity was observed. Another important feature of anionic phospholipid surfaces is that they potentially allow a two-dimensional transfer of reactants between the various enzymatic complexes. For example, FXa can be transferred from TF:FVIla to the prothrombinase complex $(121,122)$

Thus anionic phospholipids do not serve as an inert platform for the assembly of coagulation proteins but they may be considered as significant modulators of the activity of the TF.FVIla initiation complex, FIXa/FVIIla and prothrombinase. Because anionic phospholipids are primarily localized on the cytoplasmic face of the cell membrane (2), the translocation of PS to the outside of the cell surface provides a physiologically important mechanism by which cells can modulate the extent of the coagulation reaction (123).

\section{Tissue Factor Pathway Inhibitor}

In 1922, it was reported that the in vitro procoagulant activity of tissue extracts was inhibited by incubation with serum $(124,125)$. It was not untill the 1980's, however, that the relevant inhibitor was purified, cloned and characterized (126129). The serum inhibitor has been called various names, antithromboplastin, anticonvertin, lipoprotein-associated coagulation inhibitor (LACl) or extrinsic pathway inhibitor (EPI). In 1991 the currently used term, tissue factor pathway inhibitor (TFPI) was proposed and accepted (55).

Physiology. TFPI circulates in plasma at a concentration of $2.5 \mathrm{nM}(130,131)$ of which more than $90 \%$ is bound to lipoproteins by an as yet unknown mechanism. Most of this bound TFPI is associated with low density lipoprotein (LDL), a smaller fraction is bound to high density lipoprotein (HDL) and only trace amounts are found in complex with very low density lipoprotein (VLDL) (129, 131). TFPI in plasma is heterogeneous in size. The fraction associated with LDL is $34 \mathrm{kDa}$ in size whereas the TFPI associated with HDL is $41 \mathrm{kDa}$. "This HDL associated TFPI was shown to be a mixed disulfide complex of the aforementioned $34 \mathrm{kDa}$ variant with apolipoprotein II. The $34 \mathrm{kDa}$ fragment itself is a truncated form of TFPI lacking a substantial portion of the C-terminus including the last Kunitz domain (see Fig. 7). In fact only a fraction ( 0.2 to $0.4 \mathrm{nM}(132)$ ) of TFPI circulating in plasma is the fulllength molecule with a molecular weight of $43 \mathrm{kDa}$, the rest all being truncated 


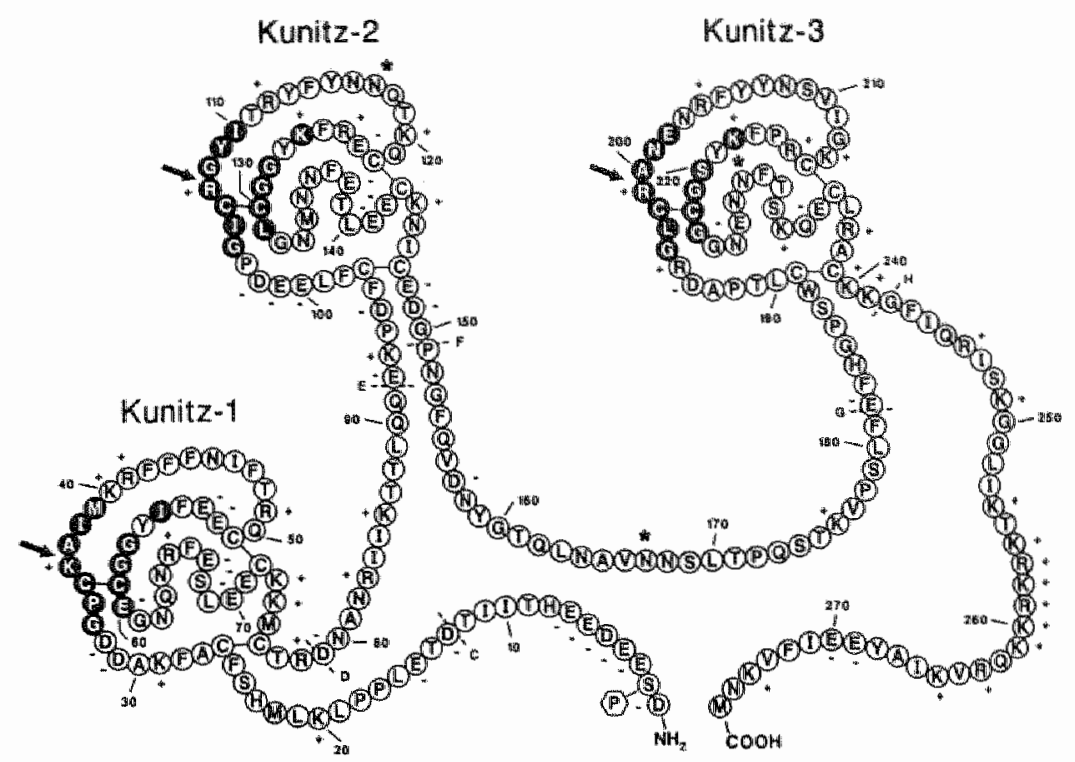

Figure 7. Structure of TFPI. Arrows indicate the $\mathrm{P}_{4}-\mathrm{P}_{4}$ active-site inhibitory clefts. In bold are shown the residues that are predicted to be in close contact with the catalytic domains of target proteinases (Adapted from (55)).

variants (133). Approximately $10 \%$ of the total blood TFPI is carried by platelets (in granules), which release TFPI following stimulation by thrombin (134). Platelet TFPI is most likely synthesized by megakaryocytes (they were shown to contain mRNA for TFPI), rather than originating from the plasma pool (134). It has been suggested that this platelet TFPI might contribute substantially to the TFPI concentration at the site of vessel wall injury, where platelets aggregate (134). Another source of (full length) TFPI is bound to the luminal surface of vascular endothelium, probably via glycosaminoglycans. This fraction of TFPI is heparin releasable, causing a 2- to 4fold increase in both plasma TFPI-antigen levels and TFPI anticoagulant activity $(135,136)$. It is tempting to speculate that not the TFPI circulating in plasma but the TFPI bound to the endothelium and in contact with plasma, is the major contributor to overall TFPI action in vivo because of the distribution throughout the vasculature and its, as explained later, full length appearance. The fact that individuals with abeta-lipoproteinaemia have very low plasma-TFPI levels $(<20 \%$ of normal) which increases to normal levels following heparin infusion and who do not have an increased risk of thrombosis, could be compatible with the suggestion that plasma indeed is not the most important reservoir of TFPI (137). 
As yet, no individuals with severe TFPI deficiency have been identified. probably because this deficiency is not compatible with life. TFPI gene disruption in mice was shown to produce intrauterine lethality. The mice showed signs of yolk sac hemorrhage and none of the TFPI $(-1-)$ fetuses survived to the neonatal period (138). The presence of fibrin in the liver and intra-vascular thrombi suggests that a consumptive coagulopathy underlies the bleeding diathesis in the embryo.

Properties of TFPL. TFPI is a member of the Kunitz family of serine protease inhibitors, which appear to act by a specific mechanism (139). That is, the inhibitor feigns to be a good substrate but after the enzyme has bound, the subsequent cleavage between the $\mathrm{P} 1$ and $\mathrm{P} 1$ ' amino acid residues (Fig. 7 ), of the active site cleft of the inhibitor, occurs only very slowly or not at all. Full length TFPI consists of 276 amino acid residues (140) and contains an acidic $\mathbb{N}$-terminal region followed by three tandemly repeated Kunitz-type inhibitory domains and a basic C-terminal region (Fig. 7). The 18 Cys residues present in TFPI are all involved in disulficle bonds. The predicted molecular weight of TFPI is $32 \mathrm{kDa}$ but on SDS-PAGE, TFPI runs with an apparent molecular weight of $42 \mathrm{kDa}$ (131). This discrepancy might be due to N-linked glycosylation at one or more of the three potential sites $(A s)^{117}$, $A s n^{167}$ and $\mathrm{Asn}^{228}$ ). Other post-translational modifications observed in the TFPI molecule are partial phosphorylation of $\operatorname{Ser}^{2}(141)$ and the presence of sulfated asparagine-linked oligosaccharides (142). These post-translational modifications do not seem to be of major importance since recombinant TFPI expressed in $E_{\text {. coli is }}$ similar to TFPI expressed by mammalian cell lines with respect to their inhibitory activity (143).

Site directed mutagenesis (144) showed that the first Kunitz domain is necessary for inhibition of the TF:FVIla complex, it interacts with the active site of FVlla (144). The second Kunitz domain mediates binding to FXa resulting in direct inhibition of FXa proteolytic activity $(26,145)$. Binding of FXa to TFPl occurs in a $1: 1$ stoichiometry and is $\mathrm{Ca}^{2+}$ independent. A chimeric molecule containing Kunitz-1 domain and the light chain of FXa was shown to inhibit TF:FVIla, whereas Gladomainless FXa failed to support the TFPI inhibitory activity towards TF: FVIIa (26, 146). These data suggest that binding of FXa to TFPI serves to juxtapose the various domains on separate molecules (147). No inhibitory function could be attributed to the third Kunitz domain (148) but it was shown to bind heparin $1149_{1}$ 150). The positively charged C-terminal tail has a high affinity for glycosaminoglycans (heparin, dermatan sulfate and heparan sulfate) $(150,151)$ and it was suggested to play a role in the association of TFPI with lipoproteins (152). Also a possible interaction of this domain with anionic phospholipids has been proposed (153). 


\section{Regulation of the TF-Dependent Coagulation by TFPI}

As outlined previously, the initial burst of FXa generated by TF:FVlla is shut off by TFPI, while the FIXa:FVIIla complex produces the FXa necessary to maintain haemostasis. The presence of FXa proved to be essential for a significant inhibition of TF:FVIla by plasma concentrations of TFPI. Consequently FXa is involved in turning off its own generation $(26,128,154)$. Binding and inhibition of FXa is in fact the first step in the two-step reaction mechanism that has been proposed for TFPI mediated inhibition of TF:FVIla. In the second step the FXa:TFPI complex binds to TF:FVIla resulting in the formation of a quaternary TF:FVlla:FXa:TFPI complex in which FVIla no longer has proteolytic activity.

The data regarding the importance of the TFPI C-terminus in FXa inhibition (155) and in TFPI activity in a one stage clotting assay (156) suggest that the overall TFPI inhibitory activity depends on the rate of association between FXa and TFPI. From studies on the interaction between FXa and mutants of TFPI (157) it followed

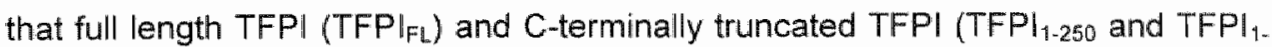
$\left.{ }_{161}\right)$ mainly differed with respect to their rate constant of association $\left(k_{o n}\right)$. Those were 4-fold lower for the truncated variants than for TFPlFL. These data thus suggest that TFPlFL is the favored inhibitor of TF:FVIla mediated FX activation. However, previous studies in a purified system $(155,158)$ showed no differences between initial rates of TF:FVIla inhibition by $\mathrm{TFPl}_{\mathrm{FL}}$ or truncated TFPI. Furthermore, in contradiction to the hypothesis, the authors proposed that the main inhibitory activity of TFPI is the direct inhibition of FXa $(155,158)$ and subsequently of prothrombinase (143). As it turned out these previous experiments were carried out under such conditions that FXa:TFPI complexes could have formed instantaneously. Previous studies by our group showed, by comparing the inhibitory activity of $F X_{a}: T_{F P I}$ and $F X_{2}: T_{F P I_{1-161}}$, that the kinetics of TF:FVIla inhibition were independent of the presence of the C-terminus (157). Only when the FXa production proceeded at low rates, TF:FVIla inhibition strongly depended on the presence of the C-terminus. Since the association of FXa:TFPI with TF:FVIla proceeded two orders of magnitude faster than the association between FXa and TFPI, it was demonstrated that the complex formation between FXa and TFPI is the rate limiting step in the inhibitory reaction during slow rates of FXa generation. Furthermore it was noted that the rate of FXa:TFPI FL $_{\text {, but not FXa:TFPI }}{ }_{1.161}$, complex formation was increased by the presence of anionic phospholipids (159), suggesting that both FXa-lipid and TFPI-lipid interactions are required for full TFPI inhibitory activity. 


\section{The Objective of This Thesis}

The described structure-function relation studies indicated that in the TF dependent pathway of blood coagulation anionic phospholipids may play a dual role. The initiation of blood coagulation by TF:FVlla is strongly stimulated by the presence of anionic phospholipid membranes. FXa:TFPI was thought to interact with anionic phospholipids as well. The aim of the studies described in this thesis was to investigate the contribution of anionic phospholipids to the inhibitory activity of TFPI towards TF:FVlla mediated FXa generation. We hypothesized that the TFPI C-terminus may play a crucial role herein. We used both neutral and negatively charged macroscopic membrane surfaces (with or without embedded TF) to which reactants were supplied under well-defined flow-conditions in order to model the processes taking place at cell membranes. Both TFPI $\left.\right|_{\text {L }}$ and TFPI 1.161 $_{\text {were }}$ wsed to study the potential membrane interaction of the C-terminus and the consequent effect that it may exert on TFPI function. In chapter 2 the measurements of equilibrium binding and residence time of the relevant proteins at planar phospholipid membranes are described resulting in kinetics of adsorption and desorption, used to characterize membrane binding. The observed loss of affinity of FXa:TFPI for anionic phospholipid membranes, apparently caused by FXa and anionic lipid, was studied in depth and is described in chapter 3. The next two chapters deal with the analysis of TF:FVIla inhibition kinetics by TFPI at synthetic phospholipid membranes (chapter 4) and at fibroblasts (chapter 5). From these data stems the hypothesis that entities competing with FXa:TFPI for phospholipid binding sites may cause an imbalance between the pro- and anticoagulant activity of phospholipid membranes, shifting it towards a procoagulant activity. To verify this hypothesis we investigated the TF:FVIla dependent FXa and thrombin generation in patients suffering from Hughes' syndrome, carrying antibodies against lipid-protein complexes with high affinity for anionic phospholipids, the results of which are presented in chapter 6 .

\section{References}

1. Sixma JJ and de Groot PG (1994) Regulation of platelet adhesion to the vessel wall. Amm $N$ Acad Sol 714, 190-9

2. Zwaal RFA, Comfurius $P$ and vam Deenen LLM (1977) Membrane asymmetry and blood coagulation. Nature 268, 358-60.

3. Losordo DW, Rosenfield K, Pieczek A, Baker K. Harding M and Isner JM (1992) How does angloplasty work? Serial analysis of human iliac arteries using intravascular ultrasound. Circulation $86,1845-58$. 
4. Nath FC, Muller DW, Ellis SG, Rosenschein U, Chapekis A, Quain L, Zimmeman $C$ and Topol EJ (1993) Thrombosis of a flexible coil coronary stent: frequency, predictors and dinical outcome. J Am Coll Cardiol 21,622-7.

5. Carrozza JP Jr. and Baim DS (1993) Complications of directional coronary atherectomy: incidence, causes, and management. Am J Cardiol 72, 47E-54 E

6. Levi M, ten Cate $H$, van der Poll $T$ and wan Deventer SJ (1993) Pathogenesis of disseminated intravascular coagulation in sepsis. Jama 270, 975-9.

7. Semeraro $N$ and Colucci $M$ (1992) Changes in the coagulation-fibrinolysis balance of endothelial cells and mononuclear phagocytes: role in disseminated intravascular coagulation associated with infectious diseases, Int J Clin Lab Res 21, 214-20.

8. Badimon JJ, Fuster $\mathrm{V}$, Chesebro $\mathrm{JH}$ and Badimon L (1993) Coronary atherosclerosis: a multifactorial disease. Circulation 87 (Suppl II), II-3-II-6.

9. Falk E, Shah PK and Fuster V (1995) Coronary plaque disruption. Circulation 92, 657-71.

10. Fuster $\mathrm{V}$, Badimon L, Badimon JJ and Chesebro JH (1992) The pathogenesis of coronary artery disease and the acute coronary syndromes (2). N Engl J Med 326, 310-8.

11. Mac Farlane RG (1964) An enzyme cascade in the blood clotting mechanism and its function as biochemical amplifier. Nature 202 ;98-9.

12. Davie EW and Ratnoff OD (1964) Waterfall sequence of intrinsic blood coagulation. Science $145,1310-2$.

13. Saito $H$. The contact phase of blood coagulation. In: Bloom AL, Forbes CD. Thomas DP and Tuddenham EGD, eds. Haemostasis and Thrombosis, Edinburgh: Churchill Livingstone, 1994: 289-307

14. Edgington TS, Mackman N, Brand K and Ruf W (1991) The structural biology of expression and function of tissue factor. Thromb Haemost 66, 67-79.

15. Gailani D and Broze GJ Jr (1991) Factor XI activation in a revised model of blood coagulation. Science 253, 909-12.

16. Nemerson $Y(1988)$ Tissue factor and haemostasis. Blood 71, 1-8.

17. Hathaway W. Bilhasen $L$ and Hathaway $H$ (1965) Evidence for a new plasma thromboplastin factor: Case report, coagulation studies and physiological properties. Blood 26, 521 32.

18. Nemerson $Y$ and Furie $B$ (1980) Zymogens and cofactors of blood coagulation. CRC Critical Review of Biochemistry 9, 45-85.

19. Kaplan AP and Silverberg M (1987) The coagulation-kinin pathway of human plasma. Blood 70 , i -15 .

20. Addis T (1911) The pathogenesis of hereditary haemophilia. J Pathol Bacteriol 15, 427-52.

21. Patek A.J and Taylor FHL (1937) Some properties of a substance obtained from normal plasma effective in accelerating the clotting of hemophilic blood. J Clin Invest $16,113-24$.

22. Bloom AL. Inherited disarders of blood coagulation. In: Bloom AL, Forbes CD. Thomas DP and Tudenham EGD, eds. Haemostasis and Thrombosis, Edinburgh: Churchill Livingistone, 1987: $131-47$. 
23. Osterud B and Rapaport S1 ( 4977 ) Activation of factor $\mathrm{X}$ by the reaction product of tissue factor and factor VII: Additional pathway for initiating coagulation. Proc Natl Acad Sci USA 74, 5260-4.

24. Rapaport Si (1989) Inhibition of factor Vila/tissue factor-induced blood coagulation: with particular emphasis upon a factor Ka-dependent inhibitory mechanism. Blood 73, 359-65.

25. Rapaport SI (1991) The extrinsic pathway inhibitor: A regulator of tissue factor-dependent blood coagulation. Thromb Haemost 66, 6-15.

26. Broze GJ Jr, Warren LA, Novotny WF, Higuchi DA, Girard JJ and Miletich JP (1988) The lipoprotein-associated coagulation inhibitor that imhibits the factor Vll-tissue factor complex also inhibits factoi $X a$ : Insight into its possible mechanism of action. Blood 71, 335-43.

27. Broze GJ Jr, Girard TJ and Nowotny WF (1990) Regulation of coagulation by a multivalent Kunitz-type inhibitor. Biochemistry 29, 7539-46.

28. Naito $K$ and Fujkawa $K$ (1991) Activation of human blood coagulation factor $X I$ independent of factor XII. Factor XI is activated by thrombin and factor Xla in the presence of negatively charged surfaces. J Biol Chem 266, 7353-8.

29. Von dem Borne PAKR, Koppelman SJ, Bouma BN and Meijers JCM (1994) Surface independent activation of factor $\mathrm{XI}$ by thrombin in the presence of high molecular weight kininogen. Thromb Haemost 72, 397-402.

30. Jesty $\mathrm{J}$ (1986) Analysis of the generation and inhibition of activated coagulation factor $\mathrm{X}$ in pure systems and in human plasma. J Biol Chem 261, 8695-702.

31. Olds Ru, Lane DA, Mille B, Chowdhury $V$ and Thein SL (1994) Antithrombin: The principal inhibitor of thrombin. Semin Thromb Hemost 20, 353-72.

32. Jesty $\downarrow$. Lorenz $A$, Rodriguez $\rfloor$ and Wun TC (1996) Initiation of the tissue factor pathway of coagulation in the presence of heparin: Control by antithrombin III and tissue factor pathway inhibitor. Blood 87, 2301-7.

33. Rao LVM, Rapaport SI and Hoang AD (1993) Binding of factor V/la to tissue factor permits rapid antithrombin III/heparin inhibition of factor Vlla. Blood 81, 2600-7.

34. Rao LVM, Nordfang O. Hoang AD and Pendurthi UR (1995) Mechanism of antithrombin III inhibition of factor Vila/tissue factor activity on cell surfaces. Comparison with tissue factor pathway inhibitorfactor Xa-induced inhibition of factor Vila/tissue factor activity. Blood 85, 121-9

35. Barrett AJ and Starkey PM (1973) The interaction of alpha 2-macroglobulin with proteinases. Characteristics and specificity of the reaction, and a hypothesis concerning its molecular mechanism. Biochem J 133, 709-24.

36. Starkey PM (1979) The physiological inhibitors of coagulation and fibrinolysis. Amsterdam: Elsevier 221-30.

37. Esmon CT (1987) The regulation of natural anticoagulant pathways Science 235, 1348-52.

38. Esmon CT (1989) The roles of protein $\mathrm{C}$ and thrombomodulin in the regulation of blood coagulation. J Biol Chem 264, 4743-6.

39. Dahlbaick $B$ and Stenflo J. A natural anticoagulant pathway: Protein $C_{*} 5, C 4 B$-binding protein and thrombomodulin. In: Bloom $\mathrm{AL}$, Forbes $\mathrm{CD}$. Thomas $\mathrm{DP}$ and Tuddenham $\mathrm{EGD}$, eds. Haemostasis and Thrombosis, 3rd ed. Edinburgh: Churchill Livingstone, 1994: 671-98. 
40. Esmon CT (1992) The protein C anticoagulant pathway. Arterioscler Thromb 12, 135 45.

41. Heeb MJ and Griffin JH (1988) Physiologic inhibition of human activated protein C by alpha im antitrypsin. $J$ Biol Chem 263,11613-6.

42. Suzuki $K$, Deyashiki $Y$, Nishioka J and Toma K (1989) Protein $C$ inlhibitor: Structure and function. Thromb Haemost 61, 337-42.

43. Hoogendoorn $\mathrm{H}_{\text {"Th }} \mathrm{CH}$, Nesheim ME and Gilles AR (1991) Alpha 2-macroglobulin binds and inhibits activated pratein C. Blood 78, 2283-90.

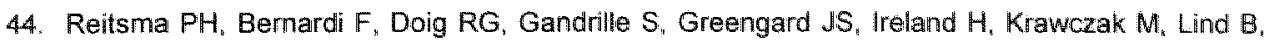
Long GL, Poort SR and et al. (1995) Protein C deficiency: A database of mutations, 1995 update. On behalf of the Subcommittee on Plasma Coagulation Inhibitors of the Scientific and Standardization Committee of the ISTH. Thromb Haemost 73, 876-89.

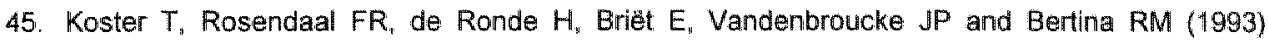
Venous thrombosis due to poor anticoagulant response to activated protein $C$ : Leiden Thrombophilia Stud. Lancet 342, 1503-6.

46. Dahlbäck B (1995) Inherited thrombophilia: resistance to activated protein $C$ as a pathogenic factor of venous thromboembolism. Blood 85,607-14.

47. Bertina RM, Koeleman BP, Koster $T$, Rosendaal FR, Dirven RJ, de Ronde $H$, van der Velden PA and Reitsma $\mathrm{PH}$ (1994) Mutation in blood coagulation factor $\mathrm{V}$ associated with resistance to activated protein $\mathrm{C}$. Nature $369,64-7$.

48. Svensson PJ and Dahlbäck B. (1994) Resistance to activated protein C as a basis for venous thrombosis. N Engl J Med 330, 517-22.

49. Voorberg J, Roelse J, Koopman R, Buller H, Berends F, ten Cate JW, Mertens K and van Mourik JA (1994) Association of idiopathic venous thromboembolism with single point- mutation at Arg506 of factor $V$. Lancet $343,1535-6$.

50. Zöller $B$, Svensson $P J$, He $X$ and Dahlbäck $B$ (1994) Identification of the same factor $V$ gene mutation in 47 out of 50 thrombosis-prone families with inherited resistance to activated protein C. J Clin Invest $94,2521-4$.

51. Drake TA, Morrissey JH and Edgington TS (1989) Selective cellular expression of tissue factor in human tissues. Am J Pathol 134 „1087-97.

52. Bevilacqua MP, Pober JS, Majeau GR, Fiers W, Cotran RS and Gimbrone MA Jr. (1986) Recombinant tumor necrosis factor induces procoagulant activity in cultured human vascular endothelium: Characterization and comparison with the actions of interleukin 1. Proc Natl Acad Sci USA $83,4533-7$.

53. Colucci $M$, Balconi $G$, Lorenzet $\mathbb{R}$. Pietra $A$, Locati $D$, Donati $M B$ and Semeraro $N(1983)$ Cultured human endothelial cells generate tissue factor in response to endotoxin. $ل$ Clin Invest 71, $1893-6$.

54. Brox $J H_{1}$ Dsterud $B_{n}$ Bjorklid $E$ and Fenton JWd (1984) Production and availability of thromboplastin in endothelial cells: the effects of thrombin, endotoxin and platelets. $\mathrm{Br} J$ Haematol 57, 239-46. 
55. Broze GJ Jr (1994) The tissue factor pathway of coagulation: Factor WII, tissue factor "and hissue factor pathway inhibitor. In: Bloom AL, Forbes CD. Thomas DP and Tuddentham EGD, eds. Haemostasis and Thrombosis, Edinburgh: Churchill Liwingstone: 349-77.

56. Camerer $E$, Kolsto $A B$ and Prydz $H$ (1996) Cell biology of tissue factor, the principal initiator of blood coagulation. Thromb Res 81, 1,41 .

57. Taubman $M B$, Marmur $J D$, Rosenfield $C_{\text {. }}$ Guha $A_{*}$ Nichtberger $S$ and Nemerson $Y$ (1993) Agonist-mediated tissue factor expresision in cultured vascular smoath muscle cells: Role of $\mathrm{Ca}^{2 *}$ mobilization and protein kinase $C$ activation. $J$ Clin Invest $94,547-52$.

58. Thiruvikraman SV, Guha $A_{6}$ Roboz J, Taubman MB, Nemerson $Y$ and Fallon JT (1996) In situ Iocalization of tissue factor in human atherosclerotic plaques by binding of digoxigenin-labeled

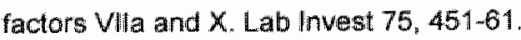

59. Wilcox JN, Smith KM, Schwartz SM and Gordon D (1989) Localization of tissue factor in the normal vessel wall and in the atherosclerotic plaque. Proc Natt Acad Sci USA 86, 2839-43.

60. Marmur JD, Thiruvikraman SV, Fyfe BS, Guha A, Sharma SK, Ambrose JA, Fallon JT, Nemerson $Y$ and Taubman MB (1996) Identification of active tissue factor in thuman coronary atheroma. Circulation $94,1226-32$.

61. Moreno PR, Bernardi VH, Lopez-Cuellar J, Murcia AM, Palacios IF, Gold HK, Mehran R, Sharma SK, Nemerson $Y$, Fuster $V$ and Fallon JT (1996) Macrophages, smooth muscle cells, and tissue factor in unstable angina. Implications for cell-mediated thrombogenicity in acute coronary syndromes. Circulation 94, 3090-7.

62. Annex BH, Denning SM, Channon KM, Sketch MH, Jr., Stack RS, Morrissey JH and Peters KG (1995) Differential expression of tissue factor protein in directional atherectomy specimens from patients with stable and unstable coronary syndromes. Circulation $91,619-22$.

63. Badimon L, Badimon JJ, Galvez A, Chesebro JH and Fuster $V$ (1986) Influence of arterial damage and wall shear rate on platelet deposition. Ex vivo study in a swine model. Arteriosclerosis 6, 312-20.

64. Mailhac A, Badimon Jل, Fallon JT, Fernandez-Ortiz A, Meyer B, Chesebro JH, Fuster $V$ and Badimon L. (1994) Effect of an eccentric severe stenosis an fibrin(ogen) deposition on severely damaged vessel wall in arterial thrombosis. Relative contribution of fibrin(ogen) and platelets. Circulation $90,988-96$.

65. Taubman MB, Fallon JT, Schecter AD. Giesen $P_{n}$, Mendlowitz M, Fyfe BS, Marmur JD and Nemerson $Y$ (1997) Tissue Factor in the Pathogenesis Of Atherosclerosis. Thromb Haemost 78 , 200-4.

66. Paborsky LR and Harris RJ (1990) Post translational modifications of recombinant human tissue factor. Thromb Res $60,367-76$.

67. Paborsky LR, Tate KM and Harris RJ (1989) Purification of recombinant human tissue factor. Biochemistry 28, 8072-7.

68. Ruf W and Edgington T (1994) Structural biology of tissue factor, the initiation of thrombogenesis in Wwo. FASEB J 8, 385-90. 
69. Bazan JF (1990) Structural design and molecular evolution of a cytokine receptor superfamih. Prac Natl Acad Sci USA 87, 6934-8.

70. Harlos $K$, Martin DM, OBrien DP. Jones EY, Stuart DI. Polikarpow I, Miller A, Tuddenham EG and Boys CW (1994) Crystal structure of the extracellular region or human tissue factor. Nature $370,662-6$.

71. Muller YA, Ulltsch MH, Kelley RF and de Vos AM (1994) Structure of the exiracellular domain of human tissue factor: Location of the factor Vlla binding site. Biochemistry 33, 10864-70.

72. Ruf $W$ and Edgington TS (1991) Two sites in the tissue factor extracellutar domain mediate the recognition of the ligand factor VIla. Proc Natl Acad Sci USA 88, 8430-4.

73. Banner DW. Darcy $A$, Chene $C$, Winkler FK. Guha A, Konigsberg WH, Nemerson $Y$ and Kirchhofer D (1996) The crystal structure of the complex of blood coagulation factor vila with soluble tissue factor. Nature $380,41-6$.

74. Andrews BS (1991) is the WKS motif the tissue factor binding site for coagulation factor VII. Trends Biochem Sci 16, 31-6.

75. Von Heijne $G$ and Gavel $Y$ (1988) Topogenic signals in integral membrane proteins. Eur $J$ Biochem 174, 674-8.

76. Fair DS (1983) Quantitation of factor VII in the plasma of normal and warfarin-treated individuals by radioimmunoassay. Blood 62, 784-91.

77. McGee MP, Devlin R, Saluta $G$ and Koren $H$ (1990) Tissue factor and factor VIII messenger RNAs in human alveolar macrophages: Effects of breathing ozone. Blood 75, 122-7.

78. Dike GWR, Griffiths D, Bidwell E, Snape TJ and Rizza CR (1980) A factor VII concentrate for therapeutic use. $\mathrm{Br} \mathrm{J}$ Haematol 45, 107-18.

79. Lawson $J H_{*}$ Butenas S, Ribarik $N$ and Mann KG (1993) Complex-dependent inhibition of factor VIla by antithrombin III and heparin. $J$ Biol Chem 268, 767-70.

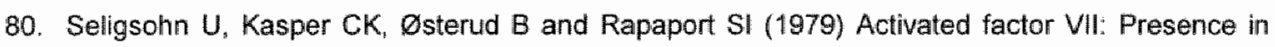
factor IX concentrates and persistence in the circulation after infusion. Blood 53, 828-37.

81. Carvalho de Sousa J, Bruckert E and Giral P (1989) Plasma factor VII triglyceride concentration and fibrin degradation products in primary hyperlipidemia: A clinical and laboratory study. Haemostasis 19, 125-30.

82. Kario K, Matsuo $T$ and Nakao K (1991) Factor V/l hyperactivity in the elderly. Thromb Haemost 65, 25-7.

83. Church WR, Boulanger LL, Messier TL and Mann KG (1989) Evidence for a common metal iondependent transition in the 4-carboxyglutamic acid domains of several vitamin K-dependent proteins. J Biol Chem 264, 1788:2-7.

84. Wildgoose $\mathbb{P}$, Jorgensen $T$, Komiyama $Y$, Nakagaki T, Pedersen A and Kisiel W (1992) The rolle of phospholipids and the factor VII Gla-domain in the interaction of factor VII with tissue factor. Thromb Haemost 67, 679-85.

85. Persson $\mathrm{E}$ and Petersen LC (1995) Structurally and functionally distinct $\mathrm{Ca}^{2+}$ binding sifes in the gamma- carboxyglutamic acid-containing domain of factor V/la. Eur J Biochem 234, 293-300. 
86. Hagen FS, Gray CL, OHara P, Grant FJ, G.C. S, Woodbury RG, Hart CE, Insley M, Kisiel W, Kurachi $K$ and Davie EW (1986) Characterization of CDNA coding for human factor VII. Proc Nat1 Acad Sci USA 83, 2412-6.

87. Titani $K$, Hermodson MA, Fujikawa $K$, Ericson LH, Walsh KA, Neurath $H$ and Davie EW (1972) Bowine factor $X$ 1a (activated Stuart factor). Evidence of homology with mammalian serine proteases. Biochemistry $11,4899-903$.

88. Bajaj SP. Fapaport SI and Brown SF (1981) Isclation and characterization of human factor VII. Activation of factor 'VIl by factor Xa. I Biol Chem 256, 253-9.

89. Radcliffe $R$ and Nemerson $Y$ (1975) Activation and control of factor VII by activated factor $X$ and thrombin. J Biol Chem 250, 388.

90. Kistel $W$, Fujikawa $K$ and Davie EW (1977) Activation of bovine factor VIl by factor Xla. Biochemistry $16,4189-94$.

91. Nakagaki T, Foster DC, Berkner KL and Kisiel W (1991) Initiation of extrinsic pathway of coagulation: Evidence for the tissue factor dependent autoactivation of human coagulation factor VIII. Blochemistry $30,10819-24$.

92. Neuenschwander PF, Fiore MM and Morrissey JH (1993) Factor VII autoactivation proceeds via interaction of distinct protease-cofactor and zymogen-cofactor complexes. Implications of a twodimensional enzyme kinetic mechanism. J Biol Chem 268, 21489-92.

93. Rao LVM and Rapaport SI (1988) Activation of factor VII bound to tissue factor: A key early step in the tissue factor pathway of blood coagulation. Proc Natl Acad Sci USA 85, 6687-91.

94. Nemerson $Y$ and Repke $D$ (1985) Tissue factor accelerates the activation of coagulation factor VII: The role of a bifunctional coagulation cofactor. Thromb Res $40,351-8$.

95. Davie EW (1995) Biochemical and molecular aspects of the coagulation cascade. Thromb Haemost $74,1-6$

96. Rapaport SI and Rao LVM (1995) The tissue factor pathway: How it has become a "prima ballerina". Thromb Haemost 74, 7-17.

97. Lawson $\mathrm{JH}_{1}$ Butenas $\mathrm{S}$ and Mann KG (1992) The evaluation of complex dependent alterations in human factor V/la. J Biol Chem 267, 4834-43.

98. Waxman $E$, Laws. WR, Laue TM Nemerson $Y$ and Ross JB (1993) Human factor Vlla and its complex with soluble tissue factor: Evaluation of asymmetry and conformational dynamics by ultracentrifugation and fluorescence anisotropy decay methods. Biochemistry $32,3005-12$.

99. McCallum CD, Hapak RC. Neuenschwander PF, Morrissey JH and Johnson AE (1996) The localion of the active site of blood coagulation factor Vila above the membrane surface and its reorientation upon association with tissue factor. A fluorescence energy transfer study. J Biol Chern 271, 28168-75.

100. Higashi $S$, Matsumoto $\mathrm{N}$ and wanaga $\mathrm{S}(1996)$ Molecular mechanism of tissue factor mediated acceleration of factor Vlla activity. J Biol Chem 27 $1,26569-74$.

101. Higashi S, Matsumoto $\mathrm{N}$ and Iwanaga S (1997) Conformation of factor Vila stabilized by a labile disulfide bond (Cys 310 Cys 329 ) in the protease domain is essential for interaction with tissue factor. J Biol Chem 272, 25724-30. 
102. Broze GJ Jir (1982) Binding of human factor VII and Vlla to monocytes. J Clin Irvest 70, 526-35.

103. Bach R, Gentry R and Nemerson Y (1986) Factor VIl binding to kissuse factor in reconstituted phospholipid vesicles. Induction of cooperativity by PS. Biochemistry $25,4007-20$.

104. Higashi S and Iwanaga S (1998) Molecular interaction between factor VII and tissue factor. Int J Hematol $67,229-41$.

105. Ruf W, Kelly CR, Schullek JR, Martin DM, Polikarpov I, Boys CW. Tuddenham EG and Edgington TS (1995) Energetic contributions and topographical organization of ligand binding residues of fissue factor. Biochemistry $34,6310 m 5$.

106. Neuenschwander PF and Morrissey JH (1994) Roles of the membrane-interactive regions of factor Vla and tissue factor. The factor Vila Gla domain is dispensable for binding to tissue factor but important for activation of fiactor X.J Biol Chem 269, 8007-13.

107. Nelsestuen $G L$, Kisiel $W$ and Di Scipio RG (1978) Interaction of vitamin K dependent proteins with membranes. Biochemistry 18, 172134-8.

108. Jackson CM (1972) Characterization of two glycoprotein variants of bovine factor $X$ and demonstration that the factor $X$ zymogen contains two polypeptide chains. Biochemistry 11 , $4873-82$.

109. Fujikawa K, Legaz ME and Davie EW (1972) Bowine factor $X 1$ (Stuart factor). Mechanism of activation by protein from Russell's viper venom. Biochemistry 11" 4892-9.

110. Jesty $J$ and Silverberg SA (1979) Kinetics of the tissue factor-dependent activation of coagulation factors $\mathrm{IX}$ and $X$ in a bowine plasma system. J Biol Chem 254, $12337-45$.

111. Almus FE, Rao LVM and Rapaport SI (1989) Functional properties of factor VIla/lissue factor formed with purified tissue factor and with tissue factor expressed on cultured endothelial cells Thromb Haemost 62, 1067-73.

112. Ruf W. Miles DJ, Rehemtulla A and Edgington TS (1992) Tissue factor residues 157-167 are required for efficient proteolytic activation of factor $X$ and factor VII. J Biol Chem 267, 22206-10.

113. Roy S, Hass PE, Bourell JH, Henzel WJ and Vehar GA (1991) Lysine residues 165 and 166 are essential for the cofactor function of tissue factor. J Biol Chem 266, 22063-6.

114. Huang Q, Neuenschwander PF, Rezaie AR and Morrissey JH (1996) Substrate recognition by tissue factor-factor Villa. Evidence for interaction of residues Lys 165 and Lys 166 of tissue factor with the 4- carboxyglutamate-rich domain of factor $X$. $J$ Biol Chem 271 ,21752-7.

115. Ruf W, Kalnik MW, Lund-Hansen T and Edgington TS (1991) Characterization of factor VII association with fissue factor in solution. High and low affinity calcium binding sites in factor VII contribute to functionally distinct regions. I Biol Chem 266, 15719-25.

116. Martin DM, O'Brien DP, Tuddenham EG and Byfield PG (1993) Synthesis and characterization of wild-type and variant gamma- carboxyglutamic acid-containing domains of factor VII. Biochemistry 32, 13949-55.

117. Ruf W. Rehemtulla $A_{8}$ Morrissey JH and Edgington TS (1991) Phospholipid independent and dependent interactions required for fissue factor receptor and cofactor function. J Biol Chem 268 , 2158-66. 
118. Knishnaswamy $S$, Field KA, Edgington TS, Morrissey JH and Mann KG (1992) Role of the membrane surface in the activation of human coagulation factor $X$. J Bial Chem 267, 26110-20.

119. Bom $\mathrm{VJ}$ and Bertina RM (1890) The contributions of $\mathrm{Ca}^{2+}$, phospholipids and tissue-factor apoprotein to the activation of human blood-coagulation factor $X$ by activated factor VII. Biochem $\mathrm{J} 265,327-36$.

120. Roy S, Paboriky LR and Vehar GA (1991) Self-association of tissue factor as revealed by chemical cross-linking. J Biol Chem 266, 4665-8.

121. Kalaratis M, Swords NA, Rand MD and Mann KG (1994) Membrane-dependent reactions in blood coagulation: Role of the vitamin K-dependent enzyme complexes. Biochim Biophys Acta 1227, 113-28.

122. Zwaal RF, Comfurius $P$ and Bevers EM (1998) Lipid-protein interactions in blood coagulation. Biochim Blophys Acta 1376, 433-53.

123. Zwaal RF and Schroit AJ (1997) Pathophysiologic implications of membrane phospholipid asymmetry in blood cells. Blood $89,1121-32$.

124. Loeb L. Fleisher MS and Tuttle L (1922) The interaction between blood serum and tissue extract in the coagulation of blood: 1 . The combined action of serum and tissue extract on flouride hirudin, and peptone plasma; the effect of heating on the serum. J Biol Chem 51, 461-83,

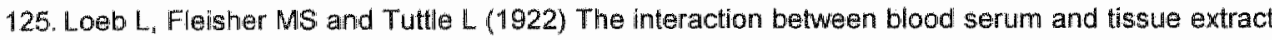
in the coagulation of blood: I. A comparison between the effects of the stroma of erythrocytes and of tissue extracts, unheated and heated, on the coagulation of the blood, and on the mechanism of the interaction of these substances with blood serum. J Biol Chem 51, 485-506.

126. Sandset PM, Abildgaard $U$ and Pettersen M (1987) A sensitive assay of extrinsic coagulation pathway inhibitor (EPI) in plasma and plasma fractions. Thromb Res $47,389-400$

127. Sanders NL. Bajaj SP, Zivelin A and Rapaport SI (1985) Inhibition of tissue factor/factor VIlla activity in plasma requires factor $X$ and an additional plasma component. Blood $85,204-12$.

128. Broze GJ Jr and Miletich JP (1987) Characterization of the initiation of tissue factor in serum. Blood 69, 150-5.

129. Hubbard AR and Jennings CA (1987) Inhibition of the tissue factor-factor VII complex: Involvement of factor Xa and lipoproteins. Thromb Res 46, 527-37.

130. Sandset PM (1996) Tissue factor pathway inhibitor (TFPI): Ain update. Heamostasis 26 (Supp 4). 154.64

131. Novotny WF, Girard TJ, Miletich JP and Broze GJ Jr (1989) Purification and characterization of the lipoprotein-associated coagulation inhibitor from human plasima. J Bial Chem 264, 18832-7.

132. Hansen IB, Huseby KR. Huseby NE, Ezban M and Nordoy A (1997) Tissue factor pathway inhibitor in complex with low density lipoprotein isolated from human plasma does nol possess anticoagulant function in tissue factor-induced coagulation in vitro. Thromb Res 85, 413 25.

133. Broze GJ Jr, Lange GW. Duffin KL and MacPhail $L$ (1994) Heterogeneity of plasma tissue factor pattway inhibitor. Blood Caagul Fibrinolysis $5,551-9$. 
134. Nowotny WF, Girard TJ, Mitefieh JP and Broze GJ Jr (1988) Platelets secivete a coagulation inhbitor functionally and intigenically similar to the lipoprotein-asssociated coagulation inhibitor Blood $72,2020-5$.

135. Lindahl AK, Sandset PM and Abildgaard U (1992) The present status of tissue factor pathway inhibitor. Blood Coagul Fibrinolysis 3, 439-49.

136. Sandset PM. Abildgaard $U$ and Larsen ML (1988) Heparin induces release of extrinsic coagulation pathway inhibitor (EPI). Thromb Res 50, 803-13.

137. Nowotny WF, Palmier M, Wun TC. Broze GJ Jr and Miletich JP (1991) Purfication and properties of heparin-releasable lipoprotein-associated coagulation inhibitor. Blood $78,394-400$.

138. Huang ZF, Higuchi D, Lasky $N$ and Broze GJ Ji (1997) Tissue factor pattway inhibitor gene disruption produces intrauterine lethality in mice. Blood 90, 944-51

139. Laskowski M and Kato ( (1980) Protein irhibitors of proteinases. Ann Rev Biochem 49, 593-626.

140. Wun TC, Kretzmer KK, Girard TJ, Mietich JP and Broze GJ Jr (1988) Cloning and characterization of a cDNA coding for the lipoprotein-associated coagulation inhibitor shows that it consists of three tandem Kunitz-type inhibitory domains. I Biol Chem 263, 6001-4.

141. Girard TJ, McCourt D, Novotny WF, MacPhail LA, Likert KM and Broze GJ Ji" (1990) Endogenous phosphorylation of the lipoprotein-associated coagulation inhibitor at serine-2. Biochem J 270, 621-5.

142. Smith PL, Skelton TP, Fiete D, Dharmesh SM, Beranek MC, Macphail L, Broze GJ J" and Baenziger JU (1992) The sapargine linked oligosaccharides on tissue factor pathway inhibitor terminate with SO4-4GAINAC(b) 1, 4GICNAC(b) 1, 2Man(a). J Biol Chem 267, 19140-6.

143. Huang ZF, Wun TC and Broze GJ JP (1993) Kinetics of Factor-Xa inhibition by tissue factor pathway inhibitor. J Biol Chem 268, 26950-5.

144. Girard TJ, Warren LA, Novotny WF, Likert KM, Brown SG, Miletich JP and Broze GJ Ji (1989) Functional significance of the Kunitz-type inhibitory domains of lipoprotein-associated coagulation inhibitor. Nature 338, 518-20.

145. Day KC and Welsch DJ (1992) Bacterial expression, purfication, and partial characterization of amino acids $94-155$ of human tissue factor pathway inhibitor (TFPI) as an inhibitor of blood coagulation factor $X a$. Thromb Res $68,369-81$

146. Warn-Cramer BJ, Rao LVM, Maki SL and Rapaport SI (1988) Modifications of extrinsic pathway inhibitor (EPI) and factor $X_{a}$ that affect their ability to interact and to inhibit factor Vilastissue factor: Evidence for a two-step model of inhibition. Thromb Haemost 60, 453-6

147. Girard TJ, MacPhail LA, Likert KM, Novotny WF, Miletich JP and Broze GJ Jr (1990) Inhibition of factor Villa-tissue factor coagulation activity by a hybrid pratein. Science 248, 1421-4.

148. Petersen LC, Björn SE, Olsen OH, Nordfang O, Norris F and Norris K (1996) Inhibitory properttes of separate recombinant Kunitz-type-protease-inhibitor domains from tissue-factor-pathway inhibitor. Eur $\mathrm{J}$ Biochem 235, 310-6.

149. Enjyoji K, Miyata T. Kamikubo $Y$ and Kato H (1995) Effect of heparin on the inhibition of factor Xa by tissue factor pathway inhibitor: a segment, Gly212-Phe243, of the third Kunitz domain is a heparin-binding site. Biochemistry 34, 5725-35. 
150. Wesselschmidt $\mathbb{R}$, Likert $K$, Huang $Z$, MacPhall $L$ and Broze GJ Jr (1993) Structural requirements for tissue factor pathway inhibitor interactions with factor Xa and heparin. Blood Coagul Fibrinelysis 4, 661-9.

151. Harenberg J, Malsch $R$ and Heene DL (1995) Tissue factor pathway inhibitor: Proposed heparin recognition region. Blood Coagul Fibrinolysis 6 Suppl 1, S50-6.

152. Valentin $S$, Nordfang $O$, Bregengard $C$ and Wildgoose $P$ (1993) Evidence that the $C$-terminus of tissue factor pathway inhibitor (TFPI) is essential for its in witro and in wivo interaction with lipoproteins. Blood Coagui Fibrinolysis 4, 713-20.

153. Valentin $S$ and Schousboe ! (1996) Factor Xa enhances the binding of tissue factor pathway inhibitor to acidic phospholipids. Thromb Haemost $75,796-800$.

154. Rao LVM and Rapaport SI (1987) Studies of a mechanism inhibiting the initiation of the extrinsic pathway of coagulation. Blood 69,645-51.

155. Wesselschmidt R, Likert $K$, Girard $T$, Wun TC and Braze GJ Jr (1992) Tissue factor pathway inhibitor: The carboxy-terminus is required for optimal inhibition of factor Xa. Blaod 79, 2004-10.

156. Nordfang O, Bjorn SE, Valentin S, Nielsen L.S, Wildgoose P, Beck TC and Hedner U (1991) The C-terminus of tissue factor pathway inhibitor is essential to its anticoagulant activity. Biochemistry 30, $10371-6$.

157. Lindhout T, Willems $G$, Blezer R and Hemker HC (1994) Kinetics of the inhibition of human factor Xa by full-length and truncated recombinant tissue factor pathway inhibitor. Biochem $J$ $297,134-6$.

158. Hamamoto $T$, Yamamoto M. Nordfang O, Petersen JG, Foster DC and Kisiel W (1993) Inhibitory properties of full-length and truncated recombinant tissue factor pathway inhibitor (TFPI). Evidence that the third Kunitz-type domain of TFPI is not essential for the inhibition of factor VIlatissue factor complexes on cell surfaces. J Biol Chem 268, 8704-10.

159. Lindhout $T$, Franssen $J$ and Willems $G$ (1995) Kinetics of the inhibition of tissue factor-factor VIla by tissue factor pathway inhibitor. Thromb Haemost $74,910-5$. 


\title{
Chapter 2
}

\section{Transient High Affinity Binding of Factor Xa:Tissue Factor Pathway Inhibitor Complexes to Negatively Charged Phospholipid Membranes}

\author{
George M. Willems, Marie P. Janssen, Irene Salemink, Tze-Chein Wun and \\ Theo Lindhout (1998) Biochemistry 37, 3321-3328
}

\section{Summary}

The interaction of tissue factor pathway inhibitor (TFPI), factor Xa (FXa) and FXa:TFPI complexes with negatively charged phospholipid membranes composed of $25 \mathrm{~mol} \%$ phosphatidylserine (PS) and $75 \mathrm{~mol} \%$ phosphatidylcholine (PC) was studied by ellipsometry. The binding of TFPI alone was negligible; FXa bound with moderate affinity, with a dissociation constant $K_{d}=42 \mathrm{nM}$. Formation of the

FXa:TFPI complex drastically enhanced the affinity for phospholipid membranes, $K_{d}$ $=5 \mathrm{nM}$, compared to that of either protein alone. TFPI ${ }_{1-181}$, a TFPI variant lacking the third Kunitz domain and the positively charged $\mathrm{C}$-terminus did not enhance binding affinity of the FXa. Analysis of the kinetics of adsorption and desorption confirmed the equilibrium binding data, although upon longer residence at the lipid membrane the desorption rate of FXa:TFPI complexes became slower, indicating an increase in affinity with longer residence of the FXa:TFPI complexes at the membrane.

In contrast, binding of FXa:TFPI complexes in the presence of an excess FXa was transient: maximal binding is followed by a slow desorption of the complex. Immunoblot analysis revealed that this desorption was accompanied with cleavage of TFPI by membrane-bound FXa. Collectively, our results show that phosphatidylserine containing membranes will accumulate tightly bound FXa:TFPI complexes, and that uncomplexed, phospholipid-bound, FXa, will cause limited proteolysis of TFPI accompanied by simultaneous release of these complexes from the phospholipid membrane. 


\section{Introduction}

The transmembrane protein tissue factor (TF) is currently considered as the main initiator of blood coagulation (1-3). Upon tissue damage, exposure to the blood of tissue factor in sub-endothelial cell membranes results in the binding and subsequent activation of circulating factor VII (FVII). The TF:FVIla complex initiates the coagulation process by activation of $F X$ and $F I X$.

The generation of FXa and IXa by TF:FVIla is regulated by tissue factor pathway inhibitor (TFPI) in a rather unique pathway: first TFPI assembles with FXa in a tight binding complex, thereby inactivating FXa. This FXa:TFPI complex then associates with high affinity to the TF:FVlla complex, forming a quaternary complex that neutralizes the TF.FVIla activity $(4,5)$.

TFPI is a $42 \mathrm{kDa}$, highly glycosylated, plasma protein that contains three Kunitz type domains, a negatively charged $\mathbb{N}$-terminus and a positively charged $\mathrm{C}$-terminus (6) TFPl circulates in plasma predominantly in complex with lipoproteins at a concentration of $2-3 \mathrm{nM}(7)$. Using mutants expressed in mouse fibroblasts it was shown that the first Kunitz domain is essential for the interaction with FVlla and that the second domain interacts with the active site of FXa (8).

The rolle of the third Kunitz domain and the positively charged $\mathrm{C}$-terminus is, as yet, less clearly defined. On the one hand it appears that the $\mathrm{C}$-terminal truncated TFPI variant TFPl. 161 , which lacks the third Kunitz domain and the C-terminus, retains the inhibitory activity against FXa and TF:FVlla $(9,10)$. On the other hand, the anticoagulant effect in plasma of C-terminal truncated variants was much less than that of the native protein (9). In a purified model system we showed a more rapid inhibition of TF:FV/la by full length TFPI (TFPIFL) than by TFPl 161. $_{16}$. It appeared that negatively charged phospholipid membranes accelerated the rate of association of FXa with TFP $\|_{F L}$ but not with the C-terminal truncated variants (11). In contrast, for preformed $\mathrm{FXa}$.TFPI complexes the rate of association with TF:FVla incorporated in phospholipid membranes was unaffected by the third Kunitz domain and the positively charged C-terminus. It should be mentioned, however, that another recent study showed no effect of phospholipids on the FXa:TFPI association (12). Recently, it was shown that the Cuterminus plays a critical role in the binding of TFPI to negatively charged phospholipid membranes (13). Taken together these data suggest a role of the C-terminus in the kinetics of TF:FVlla inhibition, presumably mediated by interaction of TFPI or FXa:TFPl complexes with negativelly charged phospholipid membranes.

The regulatory merits of the unique pathway of TF:FVIla inactivation by the FXa:TFPI complex are ill understood, but it is tempting to speculate that these are related to the enhanced affinity for phospholipid membranes of the FXa:TFPI complex compared to TFPI alone. This increased binding of TFPI in complex with 
FXa presumably depends on the much higher affinity of the FXa for PSPC membranes compared to the weak interaction of TFPI with PSPC membranes (13).

Binding of FXa to phospholipid membranes requires acidic phospholipids in the membrane, calcium ions in solution (14) and depends upon the presence of gammacarboxylated glutamic acid (Gla) residues in the protein (15-17). Highest affinity is found for membranes containing phosphatidylserine (PS), the natural acidic phospholipid. It has been suggested that binding of FXa involves (coordinated binding via) calcium bridges between protein Gla residues and PS headgroups (18). The FXa shows a moderate affinity, with reported values of the dissociation constant between 50 and $500 \mathrm{nM}$ for membranes containing 20-30 mol\% PS (18-21).

To unravel the role of membrane association of TFPI and FXa:TFPI complexes in the inactivation of TF:FVlla complexes, detailed information regarding the equilibrium binding and the residence time of the relevant proteins at the imembrane is required. Unfortunately, at present only qualitative data are available on the interaction of TFPI and FXa:TFPI complexes with phospholipid membranes (13). Here, we report a study of the interaction of TFPI and FXa:TFPI complexes with phospholipid membranes using ellipsometry $(22,23)$ for the quantitative determination of protein binding to planar membranes. Equilibrium binding isotherms were measured and kinetics of adsorption and desorption were analyzed in an attempt to characterize the membrane binding.

\section{Materials and Methods}

Materials. Bovine serum albumin (BSA, essentially fatty acid free) was from Sigma (St. Louis, MO, USA). 1,2-Dioleoyl-s/-glycero(3)phosphocholine (PC) and 1,2dioleoyl-sn-glycero(3)phosphoserine (PS) were purchased from Avanti Polar Lipids (Alabaster, AL, USA). Enhanced chemiluminescence (ECL) Western blotting delection reagents and Hyperfilm ${ }^{\text {trm }}$-ECL were provided by Amersham Life Science (Buckinghamshire, England). Nitrocellulose transfer membrane $(0.2 \mu \mathrm{m}$ ) was obtained from Protran (Dassel, Germany). Other chemicals used were of analytical grade. Silicon slides were from Aurel $\mathrm{GmbH}$ (Landsberg, Germany).

Proteins. Purified human FX (24) was activated and isolated as described earlier (25). FXa was quantified as described before (26). Recombinant full length human tissue factor pathway inhibitor (TFPIFL) was produced in Escherichia coll as described before (27) and was kindly supplied by Searle/Chiron (Chesterfield, MO/ Emeryville, CA). This recombinant TFPI preparation, being not glycosylated, has a molecular weight of $32 \mathrm{kDa}$, but is very similar to the native glycosylated protein expressed in mammalian cells with respect to FXa inhibitory activity and anticoagulant activity (27, 28). The C-terminal truncated variant of TFPI lacking the C-terminus and the third Kunitz domain, $\left.T F P\right|_{1-161}$, expressed in Saccharomyces cerevisiae and purified as 
described (29) was a kind gift of Dr. O. Nordfang (Novo Nordisk, Gentofte, Denmark). The molar concentrations of TFPI preparations were determined by titration with known amounts of FXa (30). Polyclonal goat anti-human TFPl T-161 $_{16}$ antibodies (31) were a kind gift of Dr. O. Nordfang (Novo Nordisk. Gentofte, Denmark). Swine antigoat IgG, labeled with horse radish peroxidase, was purchased from Caltag Laboratories (San Fransisco, CA).

Phospholipid Bilayers. Phospholipid concentrations were determined by phosphorous analysis (32). Planar bilayers were deposited on silicon slides as described previously (33). Briefly, small unilamellar vesicles were prepared by sonication of a mixture of $25 \mathrm{~mol} \%$ PS and $75 \mathrm{~mol} \%$ PC (PSPC). The silicon slides were thoroughly cleaned, treated with chromic sulfuric acid and extensively rinsed with water before use. A planar bilayer was deposited on the slide by immersion for $5 \mathrm{~min}$ in a stirred suspension of small unilamellar phospholipid vesicles $(30 \mu \mathrm{M})$ in Tris-buffer (50 mM Tris, $175 \mathrm{mM} \mathrm{NaCl}, 3 \mathrm{mM} \mathrm{CaCl}, \mathrm{pH} 7.5$ ).

Ellipsometric Determination of Protein Adsorption to Lipid Bilayers. Measurement of protein adsorption to planar bilayers by ellipsometry has been described extensively (21-23). Briefly, the technique is based on the change in reflection coefficients of reflecting surfaces, e.g. silicon surfaces, as a consequence of the adsorption of thin $(0.1$ to $10 \mathrm{~nm})$ lipid or protein films. Such changes result in an alteration of the polarization state of reflected light that can be accurately measured using an ellipsometer. The instrument and data analysis were as described $(22,23)$. In this study we used silicon slides and an angle of incidence of $68^{\circ}$, and under these conditions the mass, $\left.\Gamma(t)(\mu \mathrm{g} \mathrm{cm})^{-2}\right)$, of adsorbed protein (or phospholipid) is proportional to the change, $\delta P(t)$, in the polarizer reading (degrees) caused by the adsorption: $\Gamma(t)=0.085 \delta \mathrm{P}(\mathrm{t})$. Protein adsorption experiments were performed in a trapezoidal cuvette at ambient temperature $\left(20-22{ }^{\circ} \mathrm{C}\right)$ in Tris-buffer $(50 \mathrm{mM}$ Tris, 175 $\mathrm{mM} \mathrm{NaCl}, 3 \mathrm{mM} \mathrm{CaCl} 2, \mathrm{pH} 7.5)$. Protein adsorption was initiated by addition of a small aliquot $(<250 \mu \mathrm{L})$ of a protein solution to the cuvette $(4 \mathrm{~mL})$. In order to avoid aspecific depletion of protein, the cuvette walls were blocked by a preincubation with Trisbuffer containing $10 \mathrm{mg} \mathrm{mL}^{-1}$ BSA during $15 \mathrm{~min}$. Desorption of protein was started by depletion of the protein from the solution in the cuvette by flushing the cuvette $(4 \mathrm{~mL})$ with Tris-buffer $(30-60 \mathrm{~mL})$. Accumulation of protein released from the planar lipid membrane was prevented by refreshment of the cuvette solution at a flow rate of 1 $\mathrm{mL} \min ^{-1}$.

Analysis of Equilibrium Binding. Measurements of equilibrium binding as a function of the solution concentration of protein were analyzed by using the Langmuir model for independent binding sites:

$$
\Gamma_{e q}=\Gamma_{\max } \mathrm{C} /\left(K_{d}+C\right)
$$


which relates the amount of protein $\left(\Gamma_{e q}\right)$ bound on the membrane to the protein concentration in solution $(C)$, the dissociation constant $\left(K_{d}\right)$ and the maximal protein adsorption $\left(\Gamma_{\max }\right)$. The binding parameters $K_{d}$ and $\Gamma_{\max }$ are estimated by a least squares fit of this model to experimental data.

Analysis of the Kinetics of Protein Adsorption and Desorption. The adsorption and desorption kinetics of protein to the planar membrane are determined not solely by intrinsic adsorption and desorption rates but also by the rate of mass transfer of protein from bulk solution to the adsorbing macroscopic surface. The mass transfer from buik solution to the surface, effected by convection and diffusion, depends on the flow configuration and the diffusion coefficient of the protein. This mass transport, $\mathrm{J}(\mu \mathrm{g} \mathrm{cm}$ $\left.{ }^{2} \mathrm{~s}^{-1}\right)$, is equal to the mass transfer coefficient $\Delta\left(\mathrm{cm} \mathrm{s}^{-1}\right)$, which depends on the experimental setup (flow conditions) and the diffusion constant of the protein, times the difference between the concentration in bulk solution, $\mathrm{C}_{\mathrm{b}}\left(\mu \mathrm{g} \mathrm{mL}^{-1}\right)$, and the concentration, $\mathrm{C}_{0}\left(\mu \mathrm{g} \mathrm{mL}^{-1}\right)$, near the adsorbing surface:

$$
J=\Delta\left(C_{b}-C_{o}\right)
$$

Thus the protein in the fluid immediately adjacent to the adsorbing surface is depleted, i.e. $\mathrm{C}_{o}<\mathrm{C}_{\mathrm{b}}$. In previous studies we have shown that in this situation equilibrium exists between bound protein $\Gamma\left(\mu \mathrm{g} \mathrm{cm}^{-2}\right)$ and the local concentration $C_{0}$ at the phospholipid membrane-buffer interface near the PSPC membrane, i.e. $C_{0}=K_{d} \Gamma /\left(\Gamma_{\max } \Gamma\right)$ according to eq 1. Insertion of this relation between $C_{0}$ and $\Gamma$ in eq 2 results in the following differential equation for the description of the adsorption and desorption kinetics $(34,35)$ :

$$
(d / d t) \Gamma=\Delta\left(C_{b}-C_{b}\right)=\Delta\left(C_{b}-K_{d} \Gamma /\left(\Gamma_{\max }-\Gamma\right)\right)
$$

This equation predicts that initially, at a low surface coverage, the adsorption rate is equal to the transport limit, $\Delta \mathrm{C}_{\mathrm{b}}$. With increasing surface coverage, the adsorption rate will decrease proportionally to the dissociation constant, $K_{d,}$, times $\Gamma /\left(\Gamma_{\max }-\Gamma\right)$. eq 3 also allows analysis of desorption kinetics as measured after depletion of protein from the buffer solution. If the maximal binding capacity, $\Gamma_{\max }$ is identified from equilibrium binding, measurement of the kinetics of adsorption or the kinetics of desorption allows thus determination of the dissociation constant. To this end, the kinetics of protein adsorption and desorption were analyzed by a least squares fit of the numerical solution of eq 3 to the data.

Proteolysis of TFPI and Immunoblot Analysis. TFPIFL (6 nM) was incubated with FXa (18 nM) in the presence and absence of PSPC vesicles (10 $\mu \mathrm{M})$ in Tris-buffer The reaction was stopped by adding the samples to the sample buffer for SDSPAGE (final concentrations: $0.075 \mathrm{Mi}$ Tris- $\mathrm{HCl}$, pH 6.7 containing $0.7 \%$ SDS, $1.25 \%$ B-mercaptoethanol, $10 \%$ glycerol, and $0.25 \%$ bromophenol blue). Then samples 
were incubated for $15 \mathrm{~min}$ at $100^{\circ} \mathrm{C}$. After SDS-PAGE (12\% separating gel), the samples were electrablotted onto nitrocellulose $(0.2 \mu \mathrm{m}$ pore size) and blocked with $5 \%$ non-fat dry milk in PBS (10 $\left.\mathrm{mM} \mathrm{KH}_{2} \mathrm{PO}_{4}, 150 \mathrm{mM} \mathrm{NaCl}, \mathrm{pH} 7.2\right)$. After incubation with a goat polyclonal antibody directed against human TFPl ${ }_{1-15}$ in a PBS-Tween buffer ( $10 \mathrm{mM} \mathrm{KH}_{2} \mathrm{PO}_{4,} 150 \mathrm{mM} \mathrm{NaCl}$, pH 7.2, 0.3\% Tween-20) containing $1 \mathrm{mg} \mathrm{mL}$ ${ }^{1} \mathrm{BSA}$, a secondary antibody conjugated with peroxiclase was utilized for antigen detection on the nitrocellulose by using the chemiluminescence system of Amersham Life Science (Buckinghamshire, England).

\section{Results}

In an exploratory series of experiments we compared the binding of $\mathrm{FXa}$, TFPI and FXa:TFPI complexes to phospholipid membranes composed of 25 mol\% PS and $75 \mathrm{~mol} \%$ PC. Protein adsorption to phospholipid membranes was measured by ellipsometry.

Because formation of FXa:TFPI complexes under the conditions used requires several minutes $(11,30)$, preformed FXa:TFPI complexes, prepared by incubation of FXa (240 nM) with TFPI ( $800 \mathrm{nM})$ for $15 \mathrm{~min}$, were used. Using the rate constants for FXa:TFPl association $(11,30)$ it was calculated that $99 \%$ of $F X a$ is in complex with TFPI. This incubation mixture is 40 -fold diluted in the ellipsometer cuvette (100 $\mu \mathrm{L}$ added to $4 \mathrm{~mL}$ ) resulting in a final concentration of $6 \mathrm{nM}$ FXa:TFPI complex (and 14 nM free TFPI). The half-time of release of FXa from the FXa:TFPI complex is $30-40$ min and ultimately, after attainment of the new equilibrium in the cuvette, more than $98 \%$ and $95 \%$ of $\mathrm{FXa}$ remains in complex with $\mathrm{TFPl}_{\mathrm{FL}}$ respectively $\mathrm{TFPI}_{1-161}$.

Figure $1 \mathrm{~A}$ shows that the addition of $\mathrm{FXa}(6 \mathrm{nM})$ to the ellipsometer cuvette results in an equilibrium adsorption amounting to $\Gamma=0.051 \mu \mathrm{g} \mathrm{cm}^{-2}$, whereas $\left.T F P\right|_{\mathrm{FL}}$ $(20 \mathrm{nM})$ alone results in a small adsorption of about $\Gamma=0,004 \mu \mathrm{g} \mathrm{cm}{ }^{-2}$. Despite the negligibly small binding to PSPC of TFPlFL itself, TFPl FL in complex with the phospholipid binding protein FXa causes a significant enhancement of binding affinity, resulting in a 4-fold higher adsorption $\left(\Gamma=0.19 \mu \mathrm{g} \mathrm{cm}{ }^{-2}\right)$. Fig. $1 \mathrm{~A}$ also shows that binding of FXa and FXa:TFPI $I_{F L}$ complexes requires $\mathrm{Ca}^{2+}$ ions in the buffer. That is, depletion of free $\mathrm{Ca}^{2+}$ ions from the buffer by addition of EDTA causes immediate desorption of $\mathrm{FXa}$ and $\mathrm{FXa:TFPl} F \mathrm{FL}$ complexes from the phospholipid membrane. Fig. $1 \mathrm{~B}$ shows that the $\mathrm{C}$-terminal truncated TFPI variant TFPI $\left.\right|_{1-161}$ in complex with $\mathrm{FXa}$ completely lacks the facility to enhance the binding affinity of FXa.

Equilibrium Binding Isotherms. Fig. $2 \mathrm{~A}$ shows the concentration dependent binding of $\mathrm{FXa}$. It is apparent that the adsorption is rapid and that within 5-10 min a stable plateau is reached. Adsorption of TFPIFL-FXa complexes (Fig. $2 B$ ) requires 

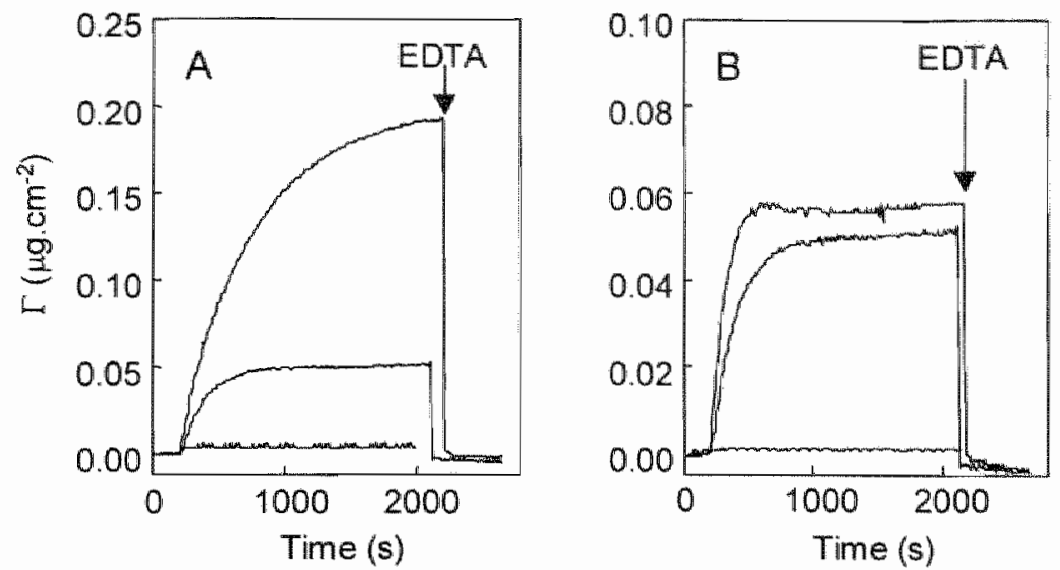

Figure 1. Adsorption of TFPI, FXa and FXa:TFPI complexes to PSPC bilayers containing $25 \mathrm{~mol} \%$ PS. At $\mathrm{t}=200 \mathrm{~s}$ protein was added to the cuwette and adsorption to the phospholipid membrane was measured by ellipsometry. Panel $A$, bottom curve:

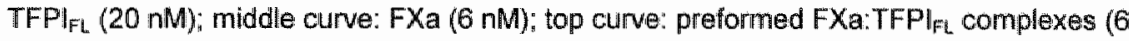
$\mathrm{nM} F \mathrm{Xa} / 20 \mathrm{nM}$ TFPl FL). At $\mathrm{t} 22100 \mathrm{~s}$, EDTA $(5 \mathrm{mM})$ was added to the cuvette in order to deplete the free calcium ions ( $3 \mathrm{nM}$ ) from the solution. Panel $\mathrm{B}$, Similar experiments were

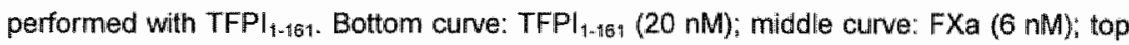
curve: preformed FXa:TFPI ${ }_{1-161}$ complexes (6 nM FXa/20 nM TFPI $1-161$ ). At $\mathrm{t} \sim 2100 \mathrm{~s}_{\mathrm{n}}$ EDTA (6 mM) was added. Experiments were performed at ambient temperature (20-22 ${ }^{\circ} \mathrm{C}$ ) in Tris-buffer (50 mM Tris, $175 \mathrm{mM} \mathrm{NaCl}, 3 \mathrm{mM} \mathrm{CaCl}_{2}, \mathrm{pH} 7.5$ ).

considerably more time $(40-60 \mathrm{~min})$ to approach equilibrium. We further note that the concentrations used in the experiments shown in Fig. 2B are 4-fold lower than the concentrations used in Fig. 2A. Similar experiments were also performed for FXa:TFPl ${ }_{1-161}$ complexes. The steady state adsorptions of FXa, FXa:TFPI $F_{L}$ and FXa:TFP| $\left.\right|_{1-161}$, measured in experiments as shown in Fig. 2, are replotted in Fig. 3 to obtain the binding isotherms of these proteins. An adequate fit of the Langmuir model for independent binding sites (solid line) to these data is apparent. It appears from Fig. 3 that the concentrations of the complexes with truncated TFPI Ti-161 $_{\text {used }}$ in these binding experiments are insufficient to saturate the binding, precluding the estimation of $\Gamma_{\max }$ from these data. Therefore the dissociation constant, $K_{\mathrm{d}}$, was estimated using the value of $\Gamma_{\max }$ found for FXa:TFPI $\mathrm{FL}_{\mathrm{L}}$ complexes. Table 1 lists the estimated values of the maximal binding, $\Gamma_{\max }$ and the dissociation constant, $K_{d-}$ These results show that FXa:TFPI L has a 7 -fold higher affinity for PSPC membranes than free $\mathrm{FXa}$. Interestingly. C-terminal truncated $\mathrm{TFPl}_{1-16,1}$ hardly influences the affinity of FXa for the PSPC membrane. 

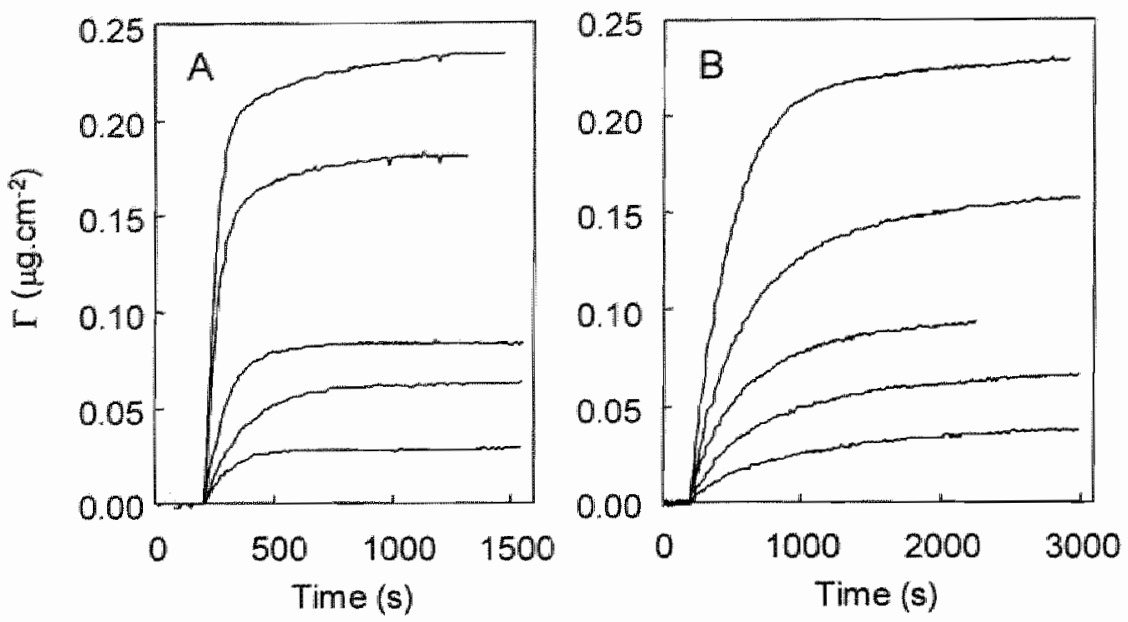

Figure 2. Concentration dependent adsorption of FXa and FXa:TFPI complexes. Protein adsorption was initiated by addition of protein to the buffer at $t=200 \mathrm{~s}$ and binding was measured by ellipsometry until a steady state adsorption was attained. Panel $A$. adsorption of FXa from bottom to top curve: 4, 8, 12, 25, $50 \mathrm{mM}$. Panel B, adsorption of preformed FXa:TFPI $I_{F L}$ complexes 1,2, 3,6, 12 nM. Preformed FXa:TFPl $I_{F L}$ complexes were prepared by incubation FXa $(40,80,160,320$ and $480 \mathrm{nM})$ and $800 \mathrm{nM}$ TFPI FL for $15 \mathrm{~min}$. Addition of $100 \mu \mathrm{L}$ of preincubated mixture to the $4 \mathrm{~mL}$ cuvette results in the indicated final concentrations. Further experimental conditions are as in Fig. 1, and y axis scales are identical in bothe $A$ and $B$.

Table 1. Binding parameters of FXa and FXa:TFPI complexes estimated from equilibribm binding experiments ${ }^{\mathrm{a}}$.

\begin{tabular}{lcl}
\hline Protein & $\mathrm{K}_{\mathrm{d}}(\mathrm{nM})$ & $\Gamma_{\max }\left(\mu \mathrm{cm}^{-2}\right)$ \\
\hline FXa & $42 \pm 2.9$ & $0.36 \pm 0.01$ \\
FXa:TFPl & $5.4 \pm 0.9$ & $0.36 \pm 0.03$ \\
FXa:TFPl & $46 \pm 3.7$ & $0.36^{\mathrm{b}}$ \\
\hline
\end{tabular}

Equilibrium binding isotherms, as presented in Fig. 3 , were analyzed using the Langmuir model for independent binding sites (eq 1 ). Presented are the least squares fit estimates (ISEM) of the dissaciation constant $K_{\mathrm{rd}}$ and of the maximal binding $\Gamma_{\text {max }}$.

Fitted with a fixed value $\Gamma_{\text {max }}=0.36$ as obtained for $F X_{\text {a:TFPI }}$ complexes. 

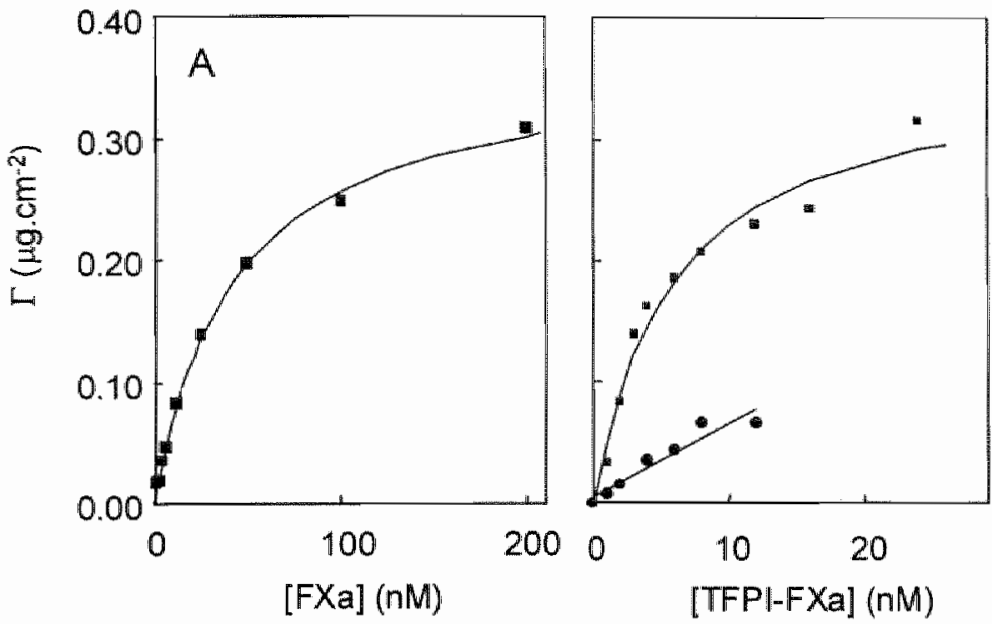

Figure 3. Equilibrium isotherms of FXa and FXa:TFPI binding to PSPC membranes. Plot of measured equilibrium binding as function solution phase concentration. Indicated are mean values of at least two independent measurements. Preformed complexes for concentrations below $14 \mathrm{nM}$ were prepared as described for Fig.2. Higher concentrations of complexes were prepared by incubation of FXa with an excess (4.5x) TFPI and were 20-fold diluted upon addition to the cuvette. Panel A, FXa binding; Panel B, binding of FXa:TFPI $I_{F L}$ complexes (1) and FXa:TFP $\|_{i-161}$ complexes (0). Solid lines indicate the least squares fit of the Langmuir model (eq 1) to these data. The estimated binding parameters are listed in Table 1 , and $y$ axis scales are identical in both $A$ and $B$.

Kinetics of Adsorption and Desorption. Ellipsometric measurements allow determination of protein binding at time intervals of about $10 \mathrm{~s}$, which is sufficiently frequent to define the kinetics of adsorption and desorption of FXa and FXa:TFPIFL complexes as is illustrated in Fig. 4. Depletion of protein from the solution initiates desorption of protein associated with the phospholipid membrane. Protein adsorption, both for FXa and FXa:TFPI FL complexes, apparently is reversible, which is in agreement with the Langmuir model presented in the methods section (eq 3). We used this model to analyze the adsorption and desorption kinetics. In the least squares fits of eq 3 to the measured protein binding vs. time the value of $K_{d}$ was adjusted, whereas fixed values for maximal binding $\Gamma_{\max }$ as presented in Table 1 (obtained from equilibrium binding experiments) were used. Satisfactory agreement between model and experimental data is shown in Fig. 4 for the adsorption and desorption kinetics of FXa. Also a good agreement was found between fit and data for the adsorption of $\mathrm{FXa:TFPl} F \mathrm{~F}$ complexes, when the fit was restricted to the initial 10-15 min of the adsorption. For the desorption data of FXa:TFPIFL complexes the fit 


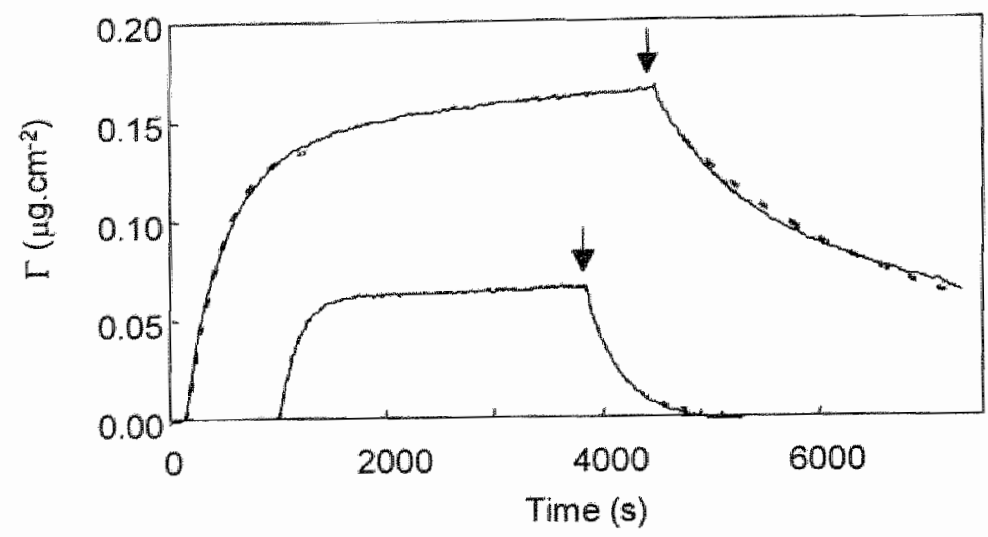

Figure 4. Adsorption and desorption kinetics of FXa and of TFPl $\mathrm{FL}_{\mathrm{L}}-\mathrm{FXa}$ complexes. Protein adsorption was initiated by addition of FXa:TFPlFL Complex (6 nM at 200 s; upper curve) or FXa (8 nM at $1000 \mathrm{~s}$; llower curve) to the cuvette. After protein adsorption reached a steady state, desorption was initiated by depletion of protein from the solution in the cuvette by flushing the $(4 \mathrm{~mL})$ cuvette with $30 \mathrm{~mL}$ Tris-buffer $(50 \mathrm{mM}$ Tris, $175 \mathrm{mM}$ $\mathrm{NaCl}_{1} 3 \mathrm{mM} \mathrm{CaCl}_{2}, \mathrm{pH} 7.5$, as indicated in the figure by the arrows. In order to avoid accumulation of desorbed protein in the buffer the cuvette solution was refreshed at a rate of $1 \mathrm{~mL} \mathrm{~min}{ }^{-1}$. The solid lines indicate the measured mass of protein associated to the phospholipid membrane; the dotted lines indicate the best fit of eq 3 to the data. Further experimental conditions are as in Fig. 1.

in Fig. 4 exhibits small but systematic deviations between measurements and model, that suggest a gradual increase in affinity with passage of time. This suspicion was reinforced by the estimation of the $K_{d}$ value from desorption kinetics of these experiments in which the desorption was initiated more than 60 min after the start of the adsorption: desorption kinetics indicated an about six-fold lower value of the $K_{d}$ than estimated from equilibrium binding (Table 1). Therefore we also studied the kinetics of desorptions that were initiated within $15 \mathrm{~min}$ after the start of the adsorption, as shown in Fig. 5. When we attempted to fit the entire course of the desorption we again found systematic deviations between fit and data. Restriction of the fit to the initial phase (10 min) of the desorption resulted in a good agreement between fit and data in this 10 min interval, but Fig. 5 also shows that beyond this interval deviations arise, indicating that desorption progresses much slower than predicted by the model fit. This fit to experiments as shown in Fig. 5 showed threefold higher desorption rates, and a correspondingly higher value of $K_{d}=2.9 \pm 0.2 \mathrm{nM}$ 


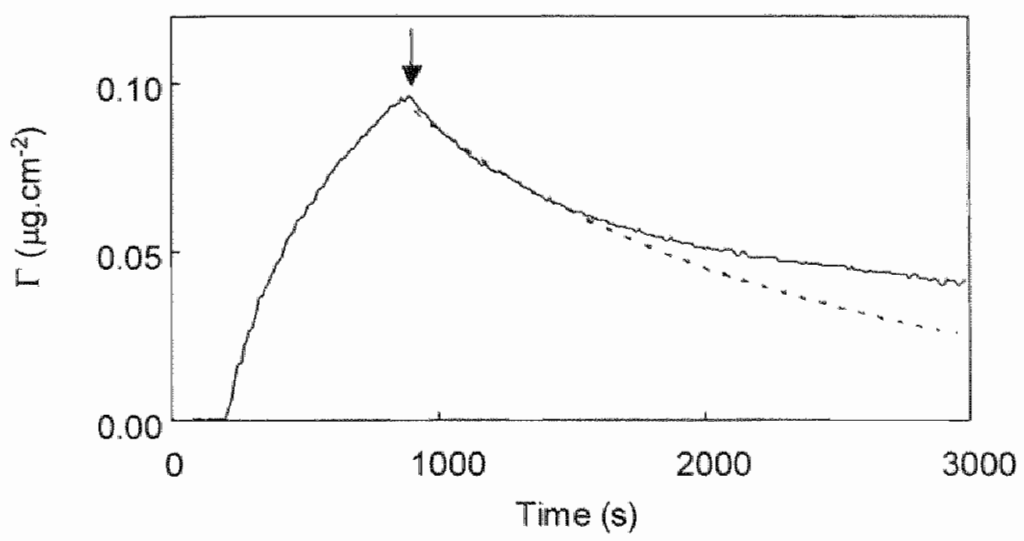

Figure 5. Desorption kinetics of TFPl $\mathrm{FL}_{\mathrm{L}} \mathrm{FXa}$ complexes. Protein adsorption was initiated by addition of $\mathrm{FXa}_{\mathrm{TFPl}}$. complex ( $4 \mathrm{nM}$ at $200 \mathrm{~s}$ ) to the cuvette. Desorption of protein was initiated by depletion of protein from the solution in the cuvette by flushing the (4 mL) cuvette with $30 \mathrm{~mL}$ Tris-buffer $t=870 \mathrm{~s}$ (arrow). The solid lines indicate the measured mass of protein associated to the phospholipid membrane; the dotted lines. indicate the best fit of eq 3 to the initial 10 min of the data. Further experimental condilions are as in Fig. 4 .

(mean value \pm SEM, $n=6$ ), than experiments in which the desorption was initiated after a residence at the membrane of more than $60 \mathrm{~min}_{\text {" confirming a gradual }}$ increase of the affinity of $F X a: T F P I_{F L}$ complexes. Therefore, we limited our analysis of desorption kinetics of FXa:TFPI $F_{\mathrm{FL}}$ complexes to the initial $10 \mathrm{~min}$ of these experiments in which the desorption was initiated within $15 \mathrm{~min}$ after the start of the adsorption. The dissociation constants, estimated from adsorption and desorption kinetics, are presented in Table 2. Both for FXa and for FXa complexes with Cterminal truncated TFPI ${ }_{1-161}$ a reasonable agreement is found between dissociation constants obtained from kinetics and equilibrium binding. For FXa:TFPl $F_{\mathrm{LL}}$ complexes the $K_{d}$ estimated from desorption kinetics is $50 \%$ lower and the $K_{d}$ estimated from adsorption kinetics is marginally higher than the $K_{d}$ obtained from equilibrium binding. PSPC Dependent FXa Mediated Proteolysis of TFPIFL. The experiments with FXa:TFPI complexes described so far were performed in the presence of an excess TFPI, such that essentially all FXa is in complex with TFPI. The residual TFPI remaining uncomplexed does not complicate the experiments as the contribution of this free TFPI to the protein binding is negligible. In contrast, in mixtures with an excess FXa both FXa and FXa:TFPI complexes contribute to the protein binding 
Table 2. Binding parameters of FXa and FXa:TFPI complexes estimated from adsorption and desorption kinetics.

\begin{tabular}{lll} 
& Adsorption kinetics & \multicolumn{1}{l}{ Desorption kinetics } \\
Protein & $K_{\mathrm{d}}(\mathrm{nM})$ & \multicolumn{1}{c}{$K_{\mathrm{d}}(\mathrm{nM})$} \\
\hline FXa & $37.0 \pm 4.3$ & $28.1 \pm 3.2$ \\
FXa:TFPl & $8.2 \pm 0.8$ & $2.9 \pm 0.2$ \\
FXa:TFPl & $51.4 \pm 4.7$ & $28.7 \pm 5.4$ \\
\hline
\end{tabular}

Protein binding vs. time data, as presented in Figs 4 and 5 , were analyzed using the Langmuir model for adsorption and desorption kinetics, see eq 3. Values of maximal binding capacity " $\Gamma_{\text {max }}$ were taken from Table 1 . Analysis of desorption kinetics of FXa:TFPl FL complexes was restricted initial knetics (10 min) of experiments, see Fig. 5 and text, in which desorption was initiated within $15 \mathrm{~min}$. Presented are the mean values ( \pm SEM) of the least squares fit estimates of the dissociation constant $K_{\text {dil }}$ as obtained from adsorption and desorption kinetics of at least 5 experiments.

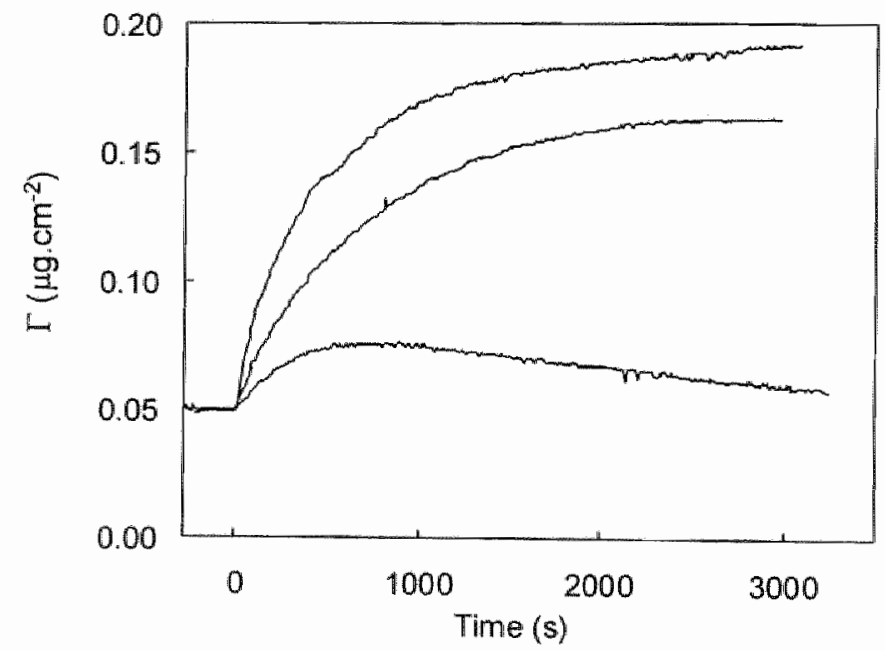

Figure 6. Transient adsorption of FXa:TFPl $\mathrm{FL}_{\mathrm{L}}$ complexes. FXa $(6 \mathrm{nM})$ was added to the cuvette and the FXa adsorption was allowed to reach a steady state $\left(\Gamma=0.05 \mu \mathrm{g} \mathrm{cm}^{-2}\right)$. TFPI $_{F 2}$ was then added to the cuvette $(t=0)$ and the protein adsorption was followed by ellipsometry. For clarity we omitted the FXa adsorption and only indicated the extra adsorption on top of the FXa adsorption, caused by addition of TFPl Fi. This extra adsorption is plotted as function of the time after addition of TFPI $\left.\right|_{F L}(t=0)$. Bottom curve:

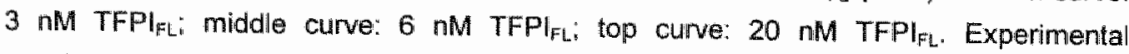
conditions as in Fig. 1 . 
measured by ellipsometry. To investigate the effect of an excess FXa on the protein binding we performed experiments as shown in Fig. 6. FXa (6 nM) was adsorbed until a steady state level was reached. Next, various concentrations $(3,6$ and $20 \mathrm{nM})$ of TFPl $F_{L L}$ were added and the additional binding of FXa:TFPlFL complexes was monitored by ellipsometry. The adsorption of FXa alone reached a stable level of $0.05-0.06 \mu \mathrm{g} \mathrm{cm}^{-2}$ within $10 \mathrm{~min}$. It is seen in Fig. 6 that addition of an excess of

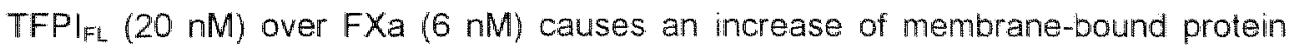

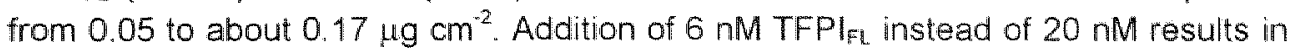
a comparable increase in protein adsorption. As expected, addition of $3 \mathrm{nM}$ TFPl FL. resulted in a significantly lower protein adsorption. However, adsorption of the FXa:TFPI $\mathrm{FL}_{\mathrm{L}}$ complex appeared to be transient. That is, a slow desorption of protein is observed after attainment of the maximal adsorption of $0.075 \mu \mathrm{g} \mathrm{cm}{ }^{-2}$. Since this phenomenon was only observed in the presence of $F X a$ in excess over TFPI $F_{\mathrm{LL}}$, the notion is raised that free FXa is likely to alter the phospholipid-binding properties of the FXa:TFPIFL complex.

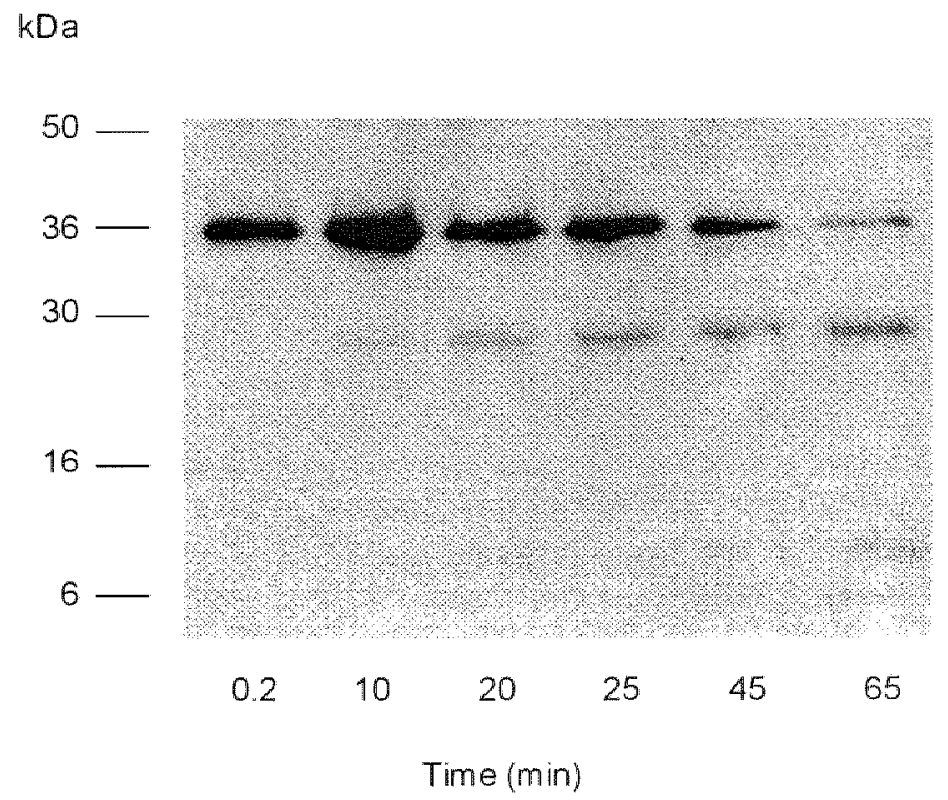

Figure 7. Immunoblot analysis of TFPl $\|_{F L}$ incubated with FXa and a PSPC planar bilayer. Reduced samples from the experiment sthown by the lower curve of Fig. $B_{\text {" }}$ taken at the indicated times after addition of TFPI to the cuvette, were subjected to SDSPAGE and Western blot analysis using an antinuman TFP| ${ }_{4.45}$, polyclonal antibody as described in the Materials and Methods. 
To find support for this notion, timed samples, taken from the ellipsometer cuvette that contained $3 \mathrm{nM}$ TFPIFL and 6 nM FXa were analyzed by SDS-PAGE and Western blotting using antibodies against TFPI 1. $_{-61}$. Fig. 7 shows the results of this experiment. The $36 \mathrm{kDa}$ band corresponding to TFPl $\left.\right|_{\mathrm{FL}}$ slowly disappears and a 26 $\mathrm{kDa}$ and a $8 \mathrm{kDa}$ band appear. No cleavage of TFPI $\mathrm{FL}$ was observed if TFPI FL was in excess (20 nM) over $\mathrm{FXa}(6 \mathrm{nM})$. Experiments, in which TFPl FL $(6 \mathrm{nM})$ was incubated with PSPC vesicles $(10 \mu \mathrm{M})$ and $\mathrm{FXa}(18 \mathrm{nM})$ at $37^{\circ} \mathrm{C}$, showed that after 60 min nearly all TFPI $\mathrm{FL}$ was converted into the $26 \mathrm{kDa}$ fragment and the $8 \mathrm{kDa}$ fragment (Fig. 8). Fig. 8 also demonstrates that cleavage of TFPIFL requires both $\mathrm{FXa}$ and PSPC membranes. Collectively, these data strongly suggest that desorption of the FXa:TFPIFL complex from PSPC membranes in Fig. 6, is caused by a phospholipidbound $F X a$ mediated proteolysis of TFPl $\mathrm{FL}_{\text {. }}$.

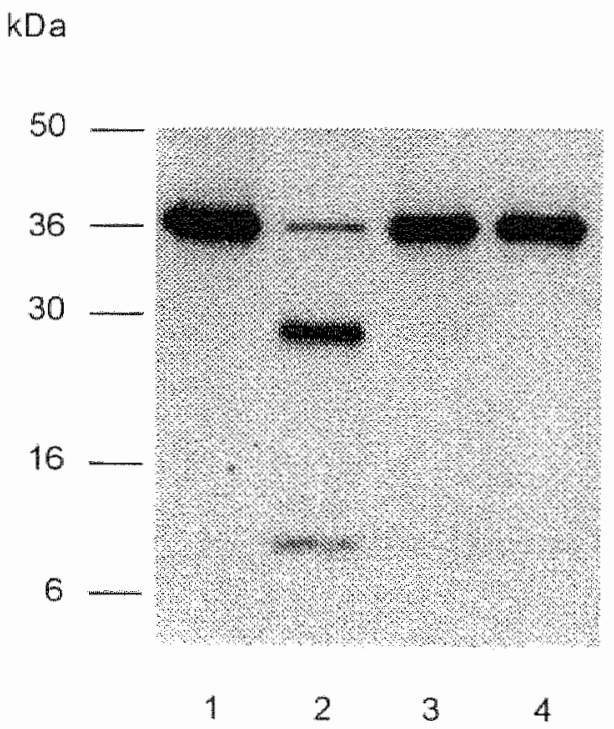

Figure 8. Immunoblot analysis of TFPI Fincubated with FXa and PSPC vesicles. TFPl $\|_{F-1}(6 \mathrm{nM}$ ) was incubated for $60 \mathrm{~min}$ with $10 \mu \mathrm{M}$ PSPC vesicles (lane 2 and 4) or without PSPC (lane 3) either in the presence of FXa (18 NM; lane 2 and 3 ) or in the absence of FXa (lane 4). A control sample of TFPlFl is shown in lane 1. Reduced samples were subjected to immunoblot analysis as described (Fig. 7 and the Materials and Methods). 


\section{Discussion.}

Our experiments clearly demonstrate that FXa:TFPlFL complexes bind with high affinity to PSPC membranes, whereas FXa complexes with the C-terminal truncated variant, $\mathrm{TFPl}_{1-161}$, bind with a considerably lower affinity, which is not different from the affinity of uncomplexed FXa. The increased affinity of the FXa:TFPlFL complex, however, appeared to be transient in the presence of an excess (over TFPlFL) of FXa. This loss of affinity during the binding experiment appears to be caused by FXa-mediated and phospholipid membrane dependent, limited proteolysis of TFPIFL.

Our finding that the interaction of $\mathrm{TFPl}_{\mathrm{FL}}$ with negatively charged phospholipid membranes is extremely weak seemingly deviates from the reported binding of TFPI FL to acidic lipids (13). In that study, however, appreciable binding of TFPlFL alone was only observed for membranes containing 60-100\% acidic phospholipid. For a lower PS content in the lipid mixture (20\% PS) and in the presence of $\mathrm{CaCl}_{2}$ $(2.5 \mathrm{mM})$, the binding of TFPI $\left.\right|_{\mathrm{FL}}$ alone was minor.

Despite its weak interaction with phospholipid membranes, TFPl $F$ with FXa drastically enhances the phospholipid binding of FXa and this enhancement apparently requires the presence of the third Kunitz domain and the $\mathrm{C}$-terminus, as it is absent for the C-terminal truncated TFPI ${ }_{1-161}$. It was suggested earlier (13) that the increased binding is caused by electrostatic interaction between positive charges on the C-terminus of TFP| $\left.\right|_{F L}$ and negative charges in the membrane. Analysis of equilibrium binding at PSPC planar bilayers (25\% PS) results in an estimated value of the dissociation constant of the FXa:TFPIFL complex that is about 8-fold lower, $K_{d}$ $=5 \mathrm{nM}$, than found for FXa alone, $K_{d}=42 \mathrm{nM}$.

Maximal binding $\left(\Gamma_{\max }\right)$ of $F X a\left(0.36 \mu \mathrm{g} \mathrm{cm}^{-2}\right)$ and of FXa:TFPl $\left.\right|_{F L}$ complexes $\left(0.36 \mu \mathrm{g} \mathrm{cm} \mathrm{cm}^{-2}\right)$ was very similar if expressed in $\mu \mathrm{g} \mathrm{cm}^{-2}$, which in terms of molecules per unit area obviously implies a lower $\Gamma_{\max }$ for $F X a$ :TFPI complexes $\left(\Gamma_{\max }=4.7\right.$ pmol $\left.\mathrm{cm}^{-2}\right)$ than for $\mathbb{F X a}\left(\Gamma_{\max }=8.1 \mathrm{pmol} \mathrm{cm}^{-2}\right)$. This is consistent with the notion that maximal binding reflects the steric constraints of tight packing on the lipid membrane of a monolayer of protein and the reasonable assumption that the footprint on the membrane of the FXa:TFPI complex is increased compared to that of FXa. The low affinity of FXa:TFPI $\left.\right|_{16161}$ complexes entails the requirement of higher concentrations complexes, than were available, to saturate the binding isotherm. This precluded the estimation of $\Gamma_{\max }$ Yet, because of the similarity in maximal binding of $F X a$ and FXa:TFPI $\mathrm{FL}_{\mathrm{w}}$ complexes, we assumed that the value of $\Gamma_{\max }$ as determined for FXa:TFPIFL, presents a reasonable estimation of the $\Gamma_{\max }$ of FXa:TFPl complexes.

For FXa and FXa:TFP| 161 complexes the $K_{d}$ value, estimated from the kinetics of adsorption and desorption of membrane-bound protein, is in acceptable agreement to the values of the dissociation constant as estimated from equilibrium binding. For FXa:TFPlFL complexes, however, we found that the desorption rate 
decreased with increasing time of residence at the lipid membrane. Nevertheless, when we limited the analysis to the initial phase $(10 \mathrm{~min})$ of desorptions initiated within $15 \mathrm{~min}$ after the start of the adsorption, we also found a reasonable agreement between the dissociation constants estimated from kinetics of desorption and adsorption and equilibrium binding (Table 2).

Despite this reasonable agreement between equilibrium binding and kinetics of adsorption and desorption, in all cases in which the desorption was followed for more than $20 \mathrm{~min}$, deviations (see Figs. 4 and 5) were observed from the model kinetics given by eq 3 with a desorption rate decreasing to a larger extent during ongoing desorption than predicted by eq 3 . This indicates an increase in affinity during desorption, a notion supported by the three-fold decrease in desorption rate, found upon prolonged $(1 \mathrm{~h})$ residence at the lipid membrane. In addition, adsorption experiments in which the $\mathrm{FXa}$ TFPI $\mathrm{FL}$ containing buffer solution was repeatedly refreshed resulted in higher amounts final adsorbed complex than found after a single addition of FXa:TFPI FL complex to the buffer (data not shown), supporting again the notion of increasing affinity of FXa:TFPl FL complexes with increasing residence time at the lipid membrane. Plateau levels as reached after a single addition of protein then presumably reflect a slowly decreasing solution phase concentration compensated by an equally slow increase of affinity. Presently we cannot offer an unambiguous explanation for this observation, though we speculate that the increased affinity is caused by slowly evolving inter-complex associations between tightly packed TFPI-factor complexes on the lipid membrane.

Interestingly, the high affinity binding of FXa:TFPI $F L$ complexes on PSPC membranes was found to be transient when FXa was present in a molar excess over TFPI. Figs. 6 and 7 clearly show that the desorption of the FXa:TFPlFL complex from the membrane is accompanied with limited proteolysis of TFPlFL, yielding under reducing conditions a $26 \mathrm{kDa}$ fragment and resulting in a nearly complete disappearance of the $36 \mathrm{kDa}$ (TFPI $\mathrm{FL}_{\mathrm{L}}$ ) band. Under the experimental conditions of Fig. 6 a minor amount of the $8 \mathrm{kDa}$ fragment is formed, which, however, appears considerably later than the onset of the desorption. In view of these data it is reasonable to speculate that the desorption is caused by the cleavage of the intact TFPI that results in the appearance of the $26 \mathrm{kDa}$ fragment.

In separate experiments we could show that the cleavage of TFP| $\left.\right|_{F L}$ is dependent on the presence of both phospholipids (Fig. 8) and requires a molar excess of FXa over TFPI. Recent work from our group (36) has demonstrated that the $26 \mathrm{kDa}$ fragment arises from a single cleavage of TFPl $\mathrm{FL}$ at $\mathrm{Arg}^{199}-\mathrm{Ala}^{200}$ a peptide bond situated within the third Kunitz domain. The $\mathrm{C}$-terminal fragment arising simultaneously, remaining invisible in Figs. 7 and 8 , apparently is not recognized by the anti-TFP| $\left.\right|_{1-161}$ antibody used in these blots.

It is interesting to bring the loss of membrane affinity attributed to the cleavage of TFPl $\mathrm{FL}_{\mathrm{L}}$ at $\mathrm{Arg}^{199}-\mathrm{Ala}^{200}$ in relation to the role to the positively charged $\mathrm{C}$ terminus in 
the TFPI-lipid interaction (13). It is thought that electrostatic interaction of this region of TFPI with negatively charged phospholipids mediates the enhanced affinity of the FXa:TFPI $F_{L L}$ complex and this tallies with the observation that TFPI ${ }_{1-161}$ in complex with FXa does not enhance the affinity for phospholipid membranes. The C-terminus of TFPI, however, remains covalently attached to the $26 \mathrm{kDa}$ fragment via disulfide bonds upon cleavage at $\mathrm{Arg}^{199}-\mathrm{Ala}^{200}$. Therefore, we speculate that the loss of affinity is caused by a major reorientation of the TFPI C-terminus in the FXa:TFPI complex, resulting in a considerably increased distance between the positive charges on the C-terminus and the lipid membrane. Alternatively, dissociation of the FXa:TFPl $I_{F L}$ complex upon proteolysis could also explain a loss in binding affinity. This, however, is less likely because of the similar high affinity FXa binding found for TFPlFL and TFPI $\left.\right|_{1-161}(11)$.

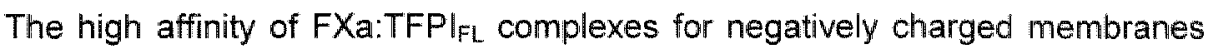
implies that FXa:TFPl $\mathrm{FL}$ complexes become localized at procoagulant (negatively charged, PS containing) membranes. Moreover, our desorption experiments show that these FXa:TFPl ${ }_{F L}$ complexes bound at PSPC membranes have an extremely long residence times ( $>45 \mathrm{~min}$ ). This long residence time was found in spite of experimental conditions that result in a very efficient mass transfer, with a value $\Delta=$ $10^{-3} \mathrm{~cm} \mathrm{~s}^{-1}$, see eq 3 .

At present it is impossible to delineate the precise functional significance of the accumulation of FXa:TFPl $\mathrm{FL}_{\mathrm{L}}$ complexes on procoagulant membranes. It is, however, tempting to speculate that these complexes, once located at procoagulant membranes " become extremely efficient inhibitors of the TF:FVlla complex. Such a mechanism could explain the difference in anticoagulant activity of full length TFPI $F$ and $\mathrm{C}$-terminal truncated $\mathrm{TFPI}_{1-161}$. If so, then FXa-catalyzed cleavage of TFPI at a procoagulant membrane may present a potent regulation of the inhibition of TF:FVIla initiated blood coagulation.

\section{Acknowledgment}

We are grateful to $\mathrm{Dr}$. Ole Nordfang for providing us with the recombinant $\mathrm{C}$ terminal truncated TFPI variant, TFPI $\left.\right|_{1-161}$, and with the goat anti-human $\operatorname{TFPI}_{1-161}$ antibody. 


\section{References}

1. Nemerson $Y(1988)$ Tissue factor and hemostasis. Blood $71,4-8$.

2. Dave EW. Fujikawa $K$ and Kisiel $W(1991)$ The coagulation cascade: initiation, maintenance; and regulation. Biochemistry $30,10363-70$.

3. Petersen LC, Valentin S and Hedner U (1995) Regulation of the extrinsic pathway system in health and disease: The role fof factor Vila and tissue factor pathway inhibitor. Thromb Res $79,1-$ 47.

4. Broze GJ Jr, Warren LA, Novotny WF, Higuchi DA, Girard JJ and Miletich JP (1988) The lipoprotein-associated coagulation inhibitor that inhibits the factor VII-tissue factor compiex also inhibits factor Xa: Insight into its possible mechanism of action. Blood 71, 335-43.

5. Rapaport $\$$ ( 1989 ) Inhibition of factor V/la/tissue factor-induced blood coagulation: With particular emphasis upon a factor Xa-dependent inhibitory mechanisin. Blood 73, 359-65.

6. Wun TC, Kretzmer KK, Girard TJ, Miletich JP and Broze GJ Jr (1988) Cloning and characterization of a cDNA coding for the lipoprotein associated caagulation inhibitor shows that it consisis of three tandem Kunitz-type inhibitory domains. J Biol Chem 263,6001-4.

7. Novoiny WF, Girard TJ, Miletich JP' and Broze GJ Jr (1989) Purification and characterization of the lipoproteinmassociated coagulation inhibitor from human piasma. J Biol Chem 264, 18832-7.

8. Girard TJ, Warren LA, Novotny WF, Likert KM, Brown SG, Miletich JP and Broze GJ Jr (1989) Functional significance of the Kunitz-fype inhibitory domains of lipoprotein-associated coagulation inhibitor. Nature 338, 518:20.

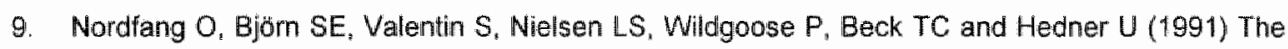
C-terminus of tissue factor pathway inhibitor is essential to its anticoagulant activity. Biochemistry $30,10371-6$.

10. Wesselschmidt $R$, Likert K, Girard T, Wun TC and Broze GJ It (1992) Tissue factor pathway inhibitor: The carboxy-terminus is required for optimal inhibition of factor $\mathrm{Xa}$. Blood 79, 2004-10.

11. Lindhout $T$. Franssen $J$ and Willems $G$ (1995) Kinetics of the inhibition of tissue factor fiactor Vlla by tissue factor pathway inhibitor. Thromb Heemastas $34,910-5$.

12. Jesty J, Wun TC and Lorenz A (1994) Kinetics of the inhibition of factor Xa and the tissue factorfactor Vlla complex by the tissue factor pathway inhibitor in the presence and absence of heparin. Biochemistry $33,12686-94$.

13. Valentin $\mathrm{S}$ and Schousboe 1 (1996) Factor $\mathrm{Xa}$ enhances the binding of tissue factor pathway inhibitor to acidic phospholipids. Thromb Haemostas 75, 796-800.

14. Nelsestuen $G L$. Broderius $M$ and Martin $G(1976)$ Role of gammawcarboxyglutamic acid. Cation specificity of prothrombin and factor X-phospholipid binding. J Biol Chem 251, 6886-93.

15. Borowski M, Furie BC, Goldsmith $\mathrm{GH}$ and Furie $B$ (1985) Metal and phospholipid binding properties of partially carboxylated human prothrombin variants. J Biol Chem 260, 9258-64.

16. Morita T and Jackson CM (1986) Localization of the structural difference between bovine blood coagulation factors $X 1$ and $X 2$ to tyrosine 18 in the activation peptide. J Biol Chem 261, 4008-14.

17. Skogen WF, Esmon CT and Cox AC (1984) Comparison of coagulation factor Xa and des-(1. 44)factor Xa in the assembly of prothrombinase. J Biol Chem 259, 2306-10. 
18. Nelsestuen GL and Lim TK (1977) Equilibria involved in prothrombin- and blood-clotting factor Xmembrane binding. Biachemistry 16,4164-71.

19. Krishnaswamy S, Jones KC and Mann KG (1988), Prothrombinase complex assembly. Kinetic mechanism of enzyme assembly on phospholipid vesicles. $J$ Biol Chem $263,3823-34$.

20. Cutsforth GA, Whitaker RN, Hermans $J$ and Lentz $B R$ (1989) A new model to describe extrinsic protein binding to phospholipid membranes of varying composition: Application to human coagulation proteins. Biochemistry 28, 7453-61.

21. Giesen PL, Willems GM, Hemker HC and Hermens WT (1991) Membrane-mediated assembly of the prothrombinase complex. J Biol Chem 266, 18720-5.

22. Cuypers PA, Corsel JW, Janssen MP, Kop JM, Hermens WT and Hemker HC (1983) The adsorption of prothrombin to phosphatidylserine mulfilayers quantitated by ellipsometry. J Biol Chem 258, 2426-31.

23. Corsel JW, Willems GM, Kop JM, Cuypers PA and Hermens WT (1985) The role of intrinsic binding rate and transport rate in the adsorption of prothrombin, albumin, and fibrinogen to phospholipid bilayers. J Colloid Interface Sci 111,544-54.

24. Mertens $K$ and Bertina RM (1980) Pathways in the activation of human coagulation factor $X$. Biochem J 1 $85,647-58$.

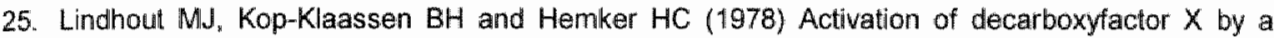
protein from Russell's viper venom. Purification and partiall characterization of activated decarboxyfactor X. Biochim Biophys Acta 533, 327-41.

26. Smith RL (1973) Titration of activated bovine Factor X. J Bial Chem 248, 24, 8-23

27. Diaz-Collier JA, Palmier MO Kretzmer KK, Bishop BF, Combs RG, Obukowicz MG, Frazier RB, Bild GS, Joy WD, Hill SR, Duffin KL, Gustafson ME, Junger KD, Grabner RW, Gallupi GR and Wun TC (1994) Refold and characterization of recombinant lissue factor pathway inhibitor expressed in Escherichia coli. Thromb Haemostas 71, 339-46.

28. Huang ZF, Wun TC and Broze GJ Ir. (1993) Kinetics of factor Xa inhibition by tissue factor pathway inhibitor. J Biol Chem 268, 26950-5.

29. Petersen JG, Mleyn G, Rasmussen JS, Petersen J, Bjön SE, Jonassen I, Chiristiansen L and Nordfang $O$ (1993) Characterization of human tissue factor pathway inhibitior variants expressed in Saccharomyces cerewisiae. J Biol Chem 268, 13344-51.

30. Lindhout $T$, Willems $G_{n}$, Blezer $R$ and Hemker HC (1994) Kinetics of the inhibition of human factor $X a$ by full-liength and truncated recombinant tissue factor pathway inhibitor. Blochem $J 297,131-6$.

31. Brinkmann $T$, Kahnert $H_{i}$ Prohaska $W$, Nordfang $O$ and Kleesiek $K$ (1994) Synthesis of tissue factor pathway inhibitor in human synovial cells and chondrocytes makes joints the predilected sife of bleeding in haemophiliacs. Eur J Clin Chem Clin Biochem 32, 313-7.

32. Bottcher CJF, Van Gent CM and Pries C (1962) A rapid and sensitive sub-micro phosphorous determination. Anall Chim Acta 24, 203-4.

33. Giesen PL, Willems GM and Hermens WT (1991) Production of thrombin by the prothrombinase complex is regulated by membrane-mediated transport of prothrombin. J Biol Chem $266,1379-82$. 
34. Andree HA, Hermens WT and Willems GM (1993) Testing protein adsorption models by off-null ellipsometry determination of binding constants from a single adsorption curve. Colloids and Surfaces $A, 78,133-44$.

35. Spaargaren J, Giesen PL, Janssen MP, Voorberg J, Willems GM and wan Mourik JA (1995) Binding of blood coagulation factor VIII and its light chain to phosphatidylserinel phosphatidylcholine bilayers as measured by ellipsometry. Biochem $\mathfrak{J} 310,539-45$.

36. Salemink I, Franssen J, Willems GM, Hemker HC and Lindhout T (1997) Limited proteolysis of tissue factor pathway inhibitor by phospholipid-bound factor $X a$ diminishes its anticoagulant activily. Thromb Haemost Supplement 408 (abstract PS-1663). 


\section{Chapter 3}

\section{FXa Cleavage of Tissue Factor Pathway Inhibitor Is Associated with Loss of Anticoagulant Activity}

Irene Salemink, Jo Franssen, George M. Willems, H. Coenraad Hemker, Anguo Li, Tze-Chein Wun and Theo Lindhout (1998)

Thrombosis and Haemostasis 80, 273-280

\section{Summary}

Tissue factor factor Vlla (TF:FVlla) induced activation of blood coagulation is inhibited by the complex between factor $\mathrm{Xa}$ and tissue factor pathway inhibitor (FXa:TFPI). We recently reported that phospholipid-bound FXa reduces the high binding affinity of FXa:TFPI for negatively charged phospholipids by a partial degradation of TFPI (Willems GM et al, Biochemistry 1998; 37:3321-3328). The present study was undertaken to elucidate the FXa cleavage sites in TFPI and to delineate the consequences of this proteolysis with respect to the inhibitory activity of FXa:TFPl. We found that phospholipid-bound FXa cleaves in TFPI or the peptide bonds between $\mathrm{Lys}^{86}-\mathrm{Thr}^{87}$ and $\mathrm{Arg}^{199}-\mathrm{Alal}^{200}$. Interestingly, $\mathrm{Arg}^{199}$ is the $\mathrm{P}_{1}$ residue of the third Kunitz-type protease inhibitor domain. The fast cleavage of the $\mathrm{Arg}^{199}{ }_{-} \mathrm{Ala}^{200}$ bond results in a $50-70 \%$ reduction of the anticoagulant activity of FXa:TFPI, as determined with a dilute TF assay, but is not associated with a diminished inhibitory activity of FXa:TFPI towards TF:FVIla catalyzed activation of FX. On the other hand, the slower cleavage of the $\mathrm{Lys}^{86}-\mathrm{Thr}^{87}$ peptide bond was associated with both a diminished anticoagulant and anti-TF:FVIla activity. Dissociation of FXa from the cleaved TFPI was not observed. These data provide evidence for a dual role of $\mathrm{FXa}$ since it is the essential cofactor in the TFPI-controlled regulation of TF-dependent coagulation as well as a catalyst of the inactivation of TFPI. 


\section{Introduction}

Tissue factor pathway inhibitor (TFPll) is the main regulator of tissue factor induced blood coagulation $(1,2)$. TFPI inhibits the generation of FXa and FIXa by the tissue factor (TF): FVlla complex in a unique manner (3). First ${ }_{1}$ TFPI binds to FXa and then in a second step, a quaternary complex between FXa:TFPI and TF:FVIla is formed, thereby neutralizing the proteolytic activity of the TF:FVlla complex.

TFPl is a plasma protein that circulates predominantly in complex with lipoproteins at a concentration of $2-3 \mathrm{nM}$ (4). The mature molecule consists of 276 amino acid residues, including 18 cysteines that are all involved in disulfide bonds (5). Post-translational modifications such as glycosylation and phosphorylation seem to be of minor importance for its inhibitory functions, since recombinant TFPI produced in Escherichia coli is indistinguishable from recombinant TFPI produced by mammalian cell lines (6). TFPI is a member of the Kunitz family of serine protease inhibitors consisting of three tandemly repeated Kunitz-type inhibition domains (each containing 6 Cys residues) flanked by an acidic $\mathrm{N}$-terminus and a basic $\mathrm{C}$-terminal tail (5). Using site directed mutagenesis (7) it was demonstrated that the Kunitz-1 domain is essential for the interaction with FVlla and that the Kunitz-2 domain interacts with the active site of FXa. No inhibitory function could be attributed to the Kunitz-3 domain (8). However, this domain was shown to be involved in the interaction of TFPI with heparin (9) and lipoproteins (10).

Various data suggest that the basic C-terminus is essential to the anticoagulant activity of TFPI. TFPI without this positively charged $\mathrm{C}$-terminus $\left(\mathrm{TFPI}_{1-250}\right)$ has been reported to have only $1 \%$ of the anticoagulant effect of full length TFPI (TFPI FL) when assayed in a dilute thromboplastin prothrombin time assay (11). Also, studies on the interaction between FXa and TFPI showed that the C-terminus of TFPI is required for optimal inhibition of FXa $(6,12)$. Previous studies from our laboratory demonstrated that the rate of association of FXa with TFPIFL was 10-fold higher than with TFPI lacking the C-terminus (13). Furthermore, we showed that negatively charged lipid membranes accelerated the rate of association of FXa with TFP|FL but not the association with the $C$-terminal truncated variants TFPI $\left.\right|_{1-250}$ and $T F P I_{1-161}$ (14). This enhanced rate of formation of the FXa:TFPlFL complex results in an accelerated rate of inhibition of the TF:FVlla catalyzed activation of FX. It should however be mentioned that another study, in which FXa was used in excess over TFPl, showed no effect of lipids on the rate of FXa:TFPI association (15).

Valentin and Schousboe (16) showed that TFPI FL binds to anionic phospholipids presumably via electrostatic interactions. We abserved minor binding for TFPlFL but found that the affinity of FXa for a planar phospholipid bilayer composed of $25 \mathrm{~mol} \%$ dioleoylphosphatidylserine and $75 \mathrm{~mol} \%$ dioleoylphosphatidylcholine was greatly enhanced when complexed with TFPl FL (17), but not with Cterminus truncated TFPI. In the same study we showed that in the presence of an 
excess FXa, FXa:TFPIFL complex shows a transient high affinity binding to negatively charged phospholipid membranes. This loss in binding affinity appeared to be associated with FXa mediated cleavage of TFPI in complex with FXa.

Proteolytic cleavage of TFPl has been reported earlier for human leukocyte elastase (HLE) $(18,19)$ and cathepsin $G(19)$. The cleavage of TFPI by FXa is, however, of particular interest, because FXa is the only protease that under physiological conditions interacts with TFPI to form the inhibitor of its own activating complex (TF:FVlla). We, therefore, investigated the functional consequences of FXa mediated proteolysis of TFPI with respect to the inhibition of blood coagulation in plasma, inhibition of TF:FVIla activation of FX and inhibition of FXa activity. Furthermore, we identified the two cleavage sites in TFPI associated with its inactivation by using immunoblot analysis and $\mathrm{N}$-terminal sequence analysis of the cleavage products.

\section{Materials and Methods}

Materials. Bovine serum albumin (BSA, essentially fatty acid free) was obtained from Sigma (St. Louis, MO). The chromogenic substrate for FXa, S2765, was purchased from Chromogenix (Mölndal, Sweden). 1,2-Dioleoyl-sn-glycero-3phosphocholine (PC) and 1,2-dioleoyl-sn-glycero-3-phosphoserine (PS) were obtained from Avanti Polar Lipids (Alabaster, AL). The plasma used was citrated (13 $\mathrm{mM})$ pooled human platelet free plasma. Electrophoresis reagents were from BioRad (Richmond, CA). Enhanced chemiluminescence (ECL) Western blotting detection reagents and Hyperfilm ${ }^{\mathrm{TM}}$-ECL were provided by Amersham Life Science (Buckinghamshire, England). Nitrocellulose transfer membrane was obtained from Protran (Dassel, Germany). Immobilon-P membranes were purchased from Millipore (Bedford, MA). All other reagents used were of analytical grade.

Proteins. Human FXa was prepared by activation of purified $F X(20)$ with the $F X$ activating protein from Russell's Viper venom (Sigma, St. Louis, MO) and isolated as was described for bovine FXa (21). The molar concentration was determined by active site titration with $p$-nitrophenyl p-guanidinobenzoate hydrochloride (pNPGB) (22). Recombinant human tissue factor pathway inhibitor (TFPI), produced in Escherichia coll (23), was kindly supplied by Searle/Chiron (Chesterfield, MO). This recombinant TFPI preparation, not being glycosylated, is very similar to the native highly glycosylated protein expressed in mammalian cells with respect to anticoagulant activity $(6,23)$. Truncated TFPI preparations were kindly supplied by Dr. Ole Nordfang (Novo Nordisk, Bagsvaerd, Denmark). The C-terminal truncated

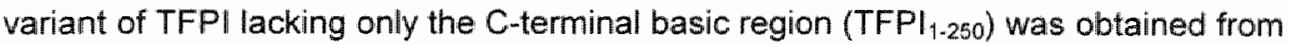
transfected baby-hamster kidney cells as described previously (24) and was isolated by cation-exchange chromatography (11). This preparation of truncated TFPI 
consists of a mixture of molecules terminated at amino acid lle-247, Ser-248, Gly250 or Thr-255 (11). The C-terminal truncated variant of TFPl lacking the third Kunitz-type domain and the C-terminal tail (TFPI 161) $_{16}$ was expressed in Saccharomyces cerevisiae and purified as described previously (25). The molar concentrations of the TFPI preparations were determined by titration with known amounts of FXa (13). Recombinant human tissue factor thrombopllastin (Dade Innovin) was purchased from Baxter Diagnostics (Deerfield. IL). The lyophilized powder was dissolved according to the manufacturer's description. Aliquots were stored at $-80^{\circ} \mathrm{C}$. Recombinant human TF was a kind gift of Dr. Yale Nemerson (Mount Sinai School of Medicine, New York, NY) and relipidated as described (14). Recombinant FWlla was a kind gift of Dr. Ulla Hedner (Novo Nordisk, Bagsvaerd, Denmark). Swine anti-goat $\mathrm{IgG}$, labeled with horse radish peroxidase, was purchased from Caltag laboratories (San Francisco, CA). Peroxidase labeled goat anti-rabbit IgG was from Jackson Immuno Research Laboratories Inc. (West Grove, PA). Polyclonal goat anti-human $r$ TFPl $_{4_{4} 961}$ antibodies $(26,27)$ were a kind gift of $\mathrm{Dr}$. Ole Nordfang (Novo Nordisk, Bagsvaerd, Denmark). Rabbit polyclonal antibodies directed against a synthetic peptide corresponding to amino acids 254-276 of TFPI C-terminus were prepared at Monsanto Company (Chesterfield, MO).

Phospholipids. Small unilamellar phospholipid vesicles compased of $25 \mathrm{~mol} \%$ PS and 75 mol\% PC (PSPC) and 100 mol\% PC vesicles (PC) were prepared as described previously (28).

Incubation Mixtures of TFPI and FXa. Preformed FXa:TFPI complexes were prepared by incubating FXa and TFPI at indicated concentrations for $10 \mathrm{~min}$ in a Tris-buffer containing $50 \mathrm{mM}$ Tris-HCl, $\mathrm{pH} 7,9,175 \mathrm{mM} \mathrm{NaCl}$ with $5 \mathrm{mM} \mathrm{CaCl}$, and $0.5 \mathrm{mg} \mathrm{mL}^{-1} \mathrm{BSA}$. This incubation time was sufficiently long to obtain an equilibrium in complex formation. In order to start FXa-mediated proteolysis of TFPI, phospholipid vesicles (of different composition) were added at indicated concentrations. All reactions were carried out at $37^{\circ} \mathrm{C}$. At timed intervals, aliquots were removed from the incubation mixture and diluted 1.5-fold in Tris-buffer containing $20 \mathrm{mM}$ EDTA to stop further proteolysis. Samples were frozen $\left(-80^{\circ} \mathrm{C}\right)$ or kept on ice until usage for SDS-PAGE/Immunoblotting, a FXa assay, a dilute TF clotting assay and TF:FVIla activity measurements.

Ge/-Electrophoresis and Immunoblot Analysis. The proteolytic fragments of TFPI were identified by electrophoresis on either $12 \%$ or gradient (4-20\%) SDSpolyacrylamide separating gels, according to Laemmli (29), and subsequent immunoblot analysis with two different antibodies. The samples for electrophoresis were incubated with $8 \mathrm{mM}$ Tris- $\mathrm{HCl}, \mathrm{pH} 6.7$ containing $0.7 \%$ SDS, $10 \%$ glycerol and $0.25 \%$ bromophenol blue, under non-reducing conditions or after reduction with $1.25 \%$ B-mercaptoethanol, at $37{ }^{\circ} \mathrm{C}$ for $30 \mathrm{~min}$. As molecular weight standards, prestained low range (SDS-PAGE standard, Bio-Rad Laboratories, Hercules, CA) or 
broad range (See Blue ${ }^{\text {TM }}$ standard, Novex, San Diego, CA) molecular weight markers were used.

After electrophoresis on a $12 \%$ SDS-PAGE the TFPI fragments were electrophoretically transferred to nitrocellulose transfer membrane $(0.2 \mu \mathrm{m}$ pore size) by semi-dry blotting at $150 \mathrm{~mA}$ for $2 \mathrm{~h}$, using $40 \mathrm{mM}$ glycine, $50 \mathrm{mM}$ Tris (pH 8.5), $0.04 \%(w / v)$ SDS, and $20 \%(v / v)$ methanol as blotting buffer. Thereafter the blots were blocked with $5 \%$ non fat dry milk in PBS buffer $\left(10 \mathrm{mM} \mathrm{KH}_{2} \mathrm{PO}_{4}, 150 \mathrm{mM} \mathrm{NaCl}\right.$. $\mathrm{pH}$ 7.22). Subsequently the nitrocellulose membrane was incubated overnight with a polyclonal antibody directed against human TFPI $\left.\right|_{-161}$, in PBS/Tween buffer $(0.3 \%$ w/v Tween-20) containing $1 \mathrm{mg} \mathrm{mL} \mathrm{mL}^{-1}$ BSA. A secondary, swine anti-goat antibody conjugated with peroxidase, was dilluted 1:4000 in PBS/Tween buffer and used for antigen detection on the nitrocellulose, by the chemiluminescence system of Amersham (Buckinghamshire, England), according to the manufacturer's description.

In order to specifically identify the low molecular weight C-terminal TFPI fragments as well as the C-terminus containing larger fragments, samples were also subjected to gradient SDS-PAGE (4-20\% gradient gel) under reducing and nomreducing conditions. After electroblotting, the proteolytic fragments were visualized with a rabbit polyclonal antibody directed against the TFPI C-terminus (residues 254 276). A secondary goat anti-rabbit antibody conjugated with peroxidase was diluted 1: 2000 in PBS/Tween/BSA buffer (0.1\% Tween-20, 0.5\% BSA) and used for antigen detection on the nitrocellulose with the chemiluminescence system of Amersham.

Amino Terminal Sequence Analysis. Reduced and non-reduced samples of incubation mixtures of TFPI $(3 \mu \mathrm{M})$, FXa $(6 \mu \mathrm{M}), 200 \mu \mathrm{M} P S P C$ and $5 \mathrm{mM} \mathrm{CaCl}_{2}$ in Tris-buffer were subjected to a $12 \%$ SDS-PAGE and electroblotted onto Immobilon-P membrane $(0.45 \mu \mathrm{m}$ pore size) by semi dry blotting as described above, using 50 $\mathrm{mM}$ Tris ( $\mathrm{pH} \mathrm{8.4),50} \mathrm{mM} \mathrm{boric} \mathrm{acid} \mathrm{and} 20 \%(\mathrm{v} / \mathrm{v})$ methanol as blotting buffer. The amount of (cleaved) TFPl applied on gel was 72 pmol. The blots were stained with Coomassie blue $(0.01 \%$ w/V Coomassie Brilliant Blue-R in $35 \%$ v/v methanol and $5 \%$ w/ $\mathrm{V}$ acetic acid). The protein bands of interest were excised and used for direct $\mathrm{N}$ terminal amino acid sequencing by automated Edman degradation, performed by Sequencing Centre Utrecht (SeCU), Utrecht. The Netherlands, using an Applied Biosystem 476A pulsed liquid sequencer (Applied Biosystems, Warrington "United Kingdom). Analysis of the sequencing data was performed with the $610 \mathrm{~A}$ data analysis system from Applied Biosystems.

FXa Assay. The residual FXa activity after incubation with TFPI, whether or not in the presence of phospholipids, was assayed by adding $5 \mu \mathrm{L}$ of the samples to polystyrene cuvettes containing $445 \mu \mathrm{L}$ of $50 \mathrm{mM}$ Tris- $\mathrm{HCl}, \mathrm{pH} 7.9,175 \mathrm{mM} \mathrm{NaCl}, 20$ $\mathrm{mM}$ EDTA and $0.5 \mathrm{mg} \mathrm{mL}^{-1} \mathrm{BSA}$, and $50 \mu \mathrm{L}$ of $3 \mathrm{mM}$ chromogenic substrate $\mathrm{S2765}$. The conversion of the chromogenic substrate was followed at $37^{\circ} \mathrm{C}$ on a dual wavelength spectrophotometer at $405 \mathrm{~nm}$ (reference wavelength $500 \mathrm{~nm}$ ), and the 
FXa concentrations were calculated from standard curves of known amounts of the enzyme (22).

Dilute TF Clotting Assay. Tris-EDTA buffer diluted samples $(10 \mu \mathrm{L})$ of incubation mixtures containing TFPI, FXa and phospholipid were added to $190 \mu \mathrm{L}$ plasma and incubated for $4 \mathrm{~min}$ at $37^{\circ} \mathrm{C}$. Then $50 \mu \mathrm{L}$ of this sample-plasma mixture was added to $100 \mu \mathrm{L}$ thromboplastin solution (Innovin, 1/500 diluted in Tris-buffer pH 7.9, containing $30 \mathrm{mM} \mathrm{Ca}^{2+}$ ) and clatting times were measured on an $\mathrm{ACL} 300 \mathrm{R}$ coagulation analyzer from Instrumentation Laboratories (Lexington, MA) (11). The clotting time was related to an anticoagulant activity (expressed as $\%$ of control) using a reference curve constructed with known amounts of preformed FXa:TFPI complex.

Inhibition of TF:FVITa Activity by TFPI. Tris-EDTA buffer diluted samples of incubation mixtures containing TFPI, FXa and phospholipid were added to a mixture containing relipidated TF $(0.1 \mathrm{nM}), \mathrm{FX}(100 \mathrm{nM}), \mathrm{CaCl}_{2}(5 \mathrm{mM})$ and PSPC $(10 \mu \mathrm{M})$ in Tris-buffer, resulting in a final concentration of $2.5 \mathrm{nM}$ (proteolytically cleaved) FXa:TFPI. This mixture was then incubated for $3 \mathrm{~min}$ at $37^{\circ} \mathrm{C}$ and $\mathrm{FX}$ activation was started by adding FVIla (1 nM). The amount of FXa formed was determined by averaging the $\mathrm{FXa}$ concentrations in the samples taken between 12 and $20 \mathrm{~min}$ after the addition of FVIIa. This maximum amount of FXa formed was related to TFPI activity using a reference curve constructed under the same conditions from known amounts of preformed FXa:TFPI complex.

\section{Results}

FXa Catalyzed Protedysis of TFPI. Previous work has indicated that TFPI is cleaved in the presence of a molar excess of FXa and a negatively charged phospholipid surface (17). Western blot analysis of incubation mixtures of TFPI with varying amounts of $F X a$ and in the presence of PSPC vesicles instead of a planar phospholipid bilayer, confirm these earlier observations. The left panel of Fig. 1 shows that incubation of $12 \mathrm{nM}$ FXa with $6 \mathrm{nM}$ TFPl in the presence of $10 \mu \mathrm{M}$ PSPC in Tris-buffer containing $5 \mathrm{mM} \mathrm{CaCl} 2$ gives within 1 min rise to the appearance of a goat-anti human TFPli-161 positive band with a molecular weight of $26 \mathrm{kDa}$. Additionally, after 20 min of incubation, a faint band of approximately $8 \mathrm{kDa}$ becomes visible, whereas TFPI has almost disappeared. When the concentration of FXa was lowered to become equal to the molar concentration of TFPI ( $6 \mathrm{nM}$, middle panel), proteolysis proceeded much slower as judged from the change in intensity of the 26 


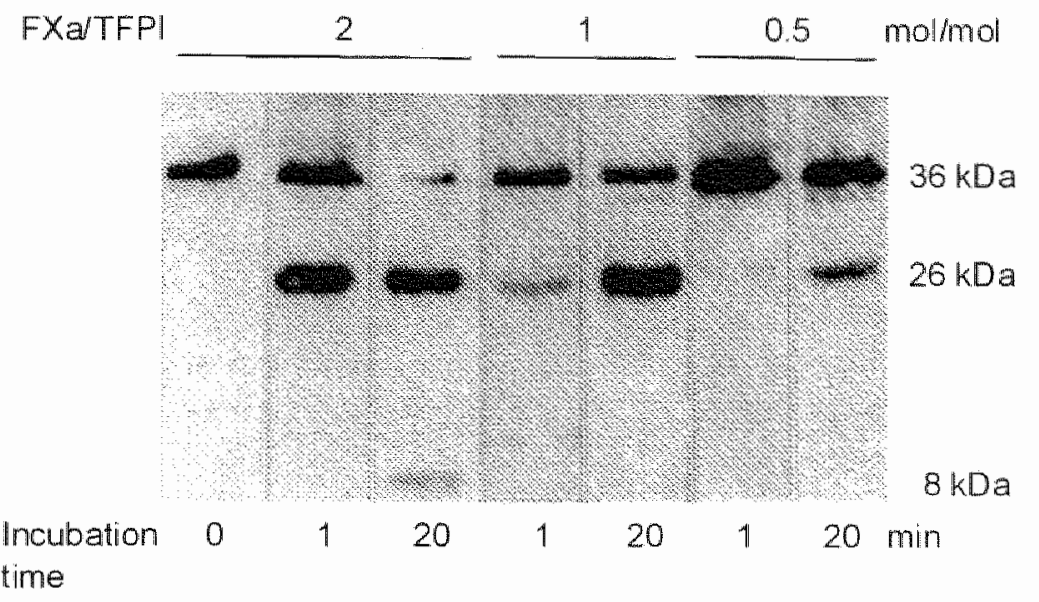

Figure 1. Cleavage of TFPI as a function of free FXa concentration. TFPI ( 6 nMM) was incubated with 12,6 or 3 NM FXa in the presence of PSPC vesicles $(10 \mu \mathrm{M})$. At timed intervals ( 1 and $20 \mathrm{~min}$ ) aliquots were removed from the incubation mixtures and the reduced samples were subjected to SDS-PAGE (12\%) and Western blotting using a goat anti-human TFPI $\left.\right|_{1-161}$ antibody.

$\mathrm{kDa}$ band during the incubation. Furthermore, the $8 \mathrm{kDa}$ fragment is absent and only a slight decrease is observed in the intensity of the band corresponding with TFPI. Under these conditions, when equimolar amounts of FXa and TFPI were incubated, the measured free $\mathrm{FXa}$ concentration was $0.5 \mathrm{nM}$ in accordance with the earlier reported dissociation constant of the FXa:TFPI complex in the presence of phospholipids (14). When the molar concentration of FXa ( $3 \mathrm{nM}$ ) is half that of TFPI (Fig. 1, right panei), the appearance of cleaved TFPl, observed within an incubation time of $20 \mathrm{~min}$, was strongly reduced. Omitting the PSPC vesicles or replacement with pure PC vesicles when TFPI was incubated with a two fold molar excess of FXa largely reduced the rate of proteolysis In both cases only a very faint band corresponding to the $26 \mathrm{kDa}$ fragment appeared after a 60 min incubation period (data not shown). These experiments thus confirm that: 1) proteolysis of TFPI in complex with FXa depends on the concentration of free FXa and 2) proteolysis is drastically accelerated by the presence of a phospholipid membrane that contains phosphatidylserine

Identification of the FXa Cleavage Sites in TFPI. To identify the cleavage pattern of TFPI caused by the FXa mediated proteolysis we performed Western blot analysis and $\mathrm{N}$-terminal sequencing of the degradation fragments. Fig. $2 \mathrm{~A}$ shows the Western blot after gradient SDS-PAGE (4-20\%) of reduced samples taken at timed intervals 
A

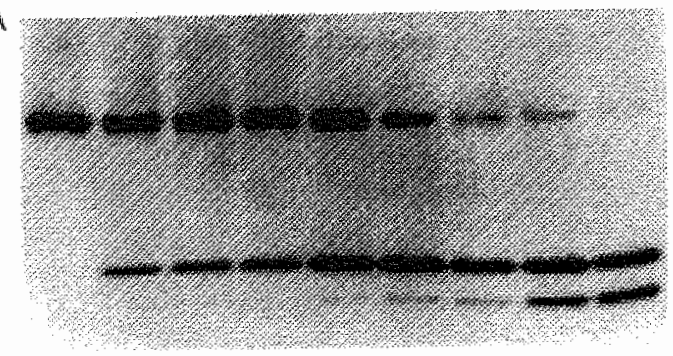

B

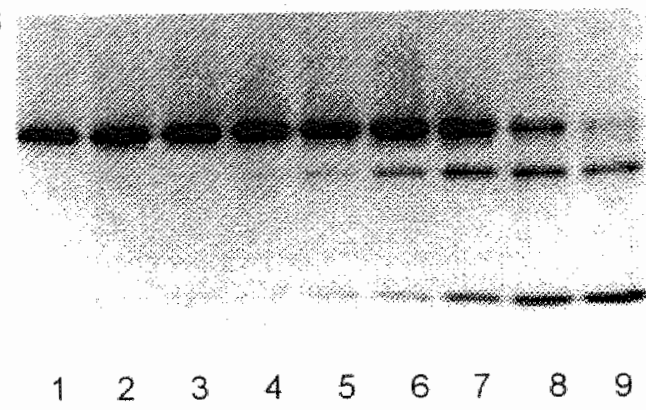

$36 \mathrm{kDa}$

$6 \mathrm{kDa}$

$3 \mathrm{kDa}$

$36 \mathrm{kDa}$

$26 \mathrm{kDa}$

$3 \mathrm{kDa}$

Figure 2. Progress of FXa-catalyzed degradation of TFPI visualized with an antibody against TFPI 254-276. TFPI (50 nM) was incubated with FXa (75 nM) for $10 \mathrm{~min}$ at $37^{\circ} \mathrm{C}$. Timed samples were taken after phospholipids were added to a final concentration of 5 IM and subjected to gradient SDS-PAGE (4-20\%) and Western blotting using an antibody against the C-terminus of TFPI. Samples were taken at $0,0.5,1,2,5,10,20,40$, and 60 min (lanes 1-9). $A$, reduced samples and $B$, unreduced samples.

from an incubation mixture that contained FXa (75 nM). TFPI (50 nM), PSPC (5 $\mu$ M) and $5 \mathrm{mM} \mathrm{CaCl}_{2}$ in Tris-buffer. The degradation fragments were visualized with an antibody directed specifically against the C-terminus of TFPI (i.e. residues 254-276). $\| t$ is shown that the band corresponding with TFPI (36 kDa) disappears concomitantly with the appearance of $\mathrm{a}-6 \mathrm{kDa}$ fragment. Upon prolonged incubation an additional $\sim 3 \mathrm{kDa}$ fragment arises. Because the antibody against $\mathrm{TFPI}_{254-276}$ solely detects degradation pepticles that contain the $\mathrm{C}$-terminus, it is evident that the $\sim 3 \mathrm{kDa}$ and $\sim 6$ $\mathrm{kDa}$ fragments result from cleavages in the $\mathrm{C}$-terminal region of TFPI. We note that the late appearing $\sim 3 \mathrm{kDa}$ fragment is seen on blots of reduced and unreduced samples (Figs. $2 A$ and $B$ ). This peptide probably results from cleavage of TFPI or $C$ terminal degradation peptides, at sites $\mathrm{Lys}^{249}-\mathrm{Gly}^{250}$ and $\mathrm{Arg}^{246}-11 \mathrm{e}^{247}$ ( $\mathrm{Li}$ et al. unpublished data). The $\sim 6 \mathrm{kDa}$ fragment on the other hand, is only seen in the blot of reduced samples (Fig. $2 \mathrm{~A}$ ) and not in the blot of the unreduced samples (Fig. 2B). This suggests that a cleavage within the Kunitz-3 domain produces a two-chain form of TFPI, where disulfide bridges link the $-6 \mathrm{kDa}$ fragment to the $\mathrm{N}$-terminal cleavage 
fragment. The non-reduced blot (Fig. 2B) shows in addition to the $\sim 3 \mathrm{kDa}$ peptide also $-26 \mathrm{kDa}$ fragment upon prolonged incubation. It is feasible that this fragment originates from another $\mathrm{FXa}$ cleavage site near the $\mathrm{N}$-terminus of TFPI. From these results we conclude that $F X$ a cleaves at least 3 peptide bonds in TFPI, namely at the $\mathrm{N}$-terminus ( $\sim 26 \mathrm{kDa}$ fragment), at the $\mathrm{C}$-terminus ( $\sim 3 \mathrm{kDa}$ fragment) and within the Kunitz-3 domain resulting in a two-chain TFPI due to the disuffide bridges.

To detect also TFPI degradation fragments that do not contain residues 254276 , we used an antibody against TFPI ${ }_{1-161}$ to visualize the $F$ Xa cleavage pattern of TFPI. Fig. 3A shows the Western blat after SDS-PAGE $(12 \%)$ of the reduced samples taken at timed intervals from an incubation mixture as described for Fig. 2 .

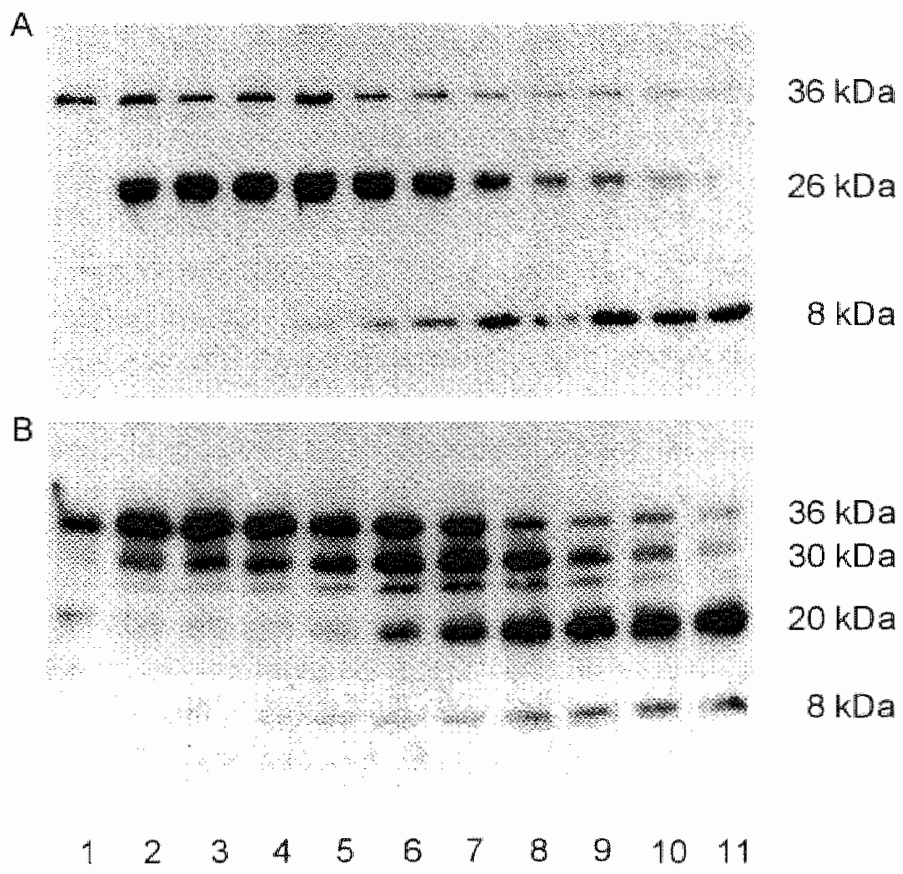

Figure 3. Progress of FXa-catalyzed degradation of TFPI visualized with an antibody against TFPI $1-161$. TFPI (50 $\mathrm{nM})$ was incubated with $\mathrm{FXa}(75 \mathrm{nM})$ in the presence of phospholipids $(5 \mu \mathrm{M})$ at $37^{\circ} \mathrm{C}$. Samples were taken at $0,0.5,1,2,5,10,20$, $40,60,80$ and 100 min (lane 1-11) and subjected to SDS-PAGE (12\%) and Western blotting using an antibody against TFPI $1-161 . A_{1}$ reduced samples and $B$, unreduced samples. 
Apparentiy, TFPl is rapidly cleaved into a $\sim 26 \mathrm{kDa}$ fragment. An $-8 \mathrm{kDa}$ peptide appears only after considerably delay. A comparison with Fig. $2 \mathrm{~A}$ suggests that this $\sim 26 \mathrm{kDa}$ fragment is the result of a cleavage in the Kunitz-3 domain. This was confirmed by the $\mathrm{N}$-terminal amino acid sequence analysis of the $\sim 26 \mathrm{kDa}$ fragment. We found that, according to the known primary structure of human TFPI $(5,7)$, the sequence (M)DSEEDEEH (see also Table 1) corresponds to residues 1-8 of TFPI. The methionine residue preceding the TFP! sequence, origins from the recombinant expression of TFPI. The $\sim 6 \mathrm{KDa}$-terminal fragment appearing in Fig. $2 \mathrm{~A}$ remains invisible in Fig. $3 \mathrm{~A}$ because it is not recognized by the antibody directed against TFPI $_{1 \cdot 181}$.

Fig. $3 B$ shows the immunoblot of the unreduced samples, taken from the same incubation mixture as described for Fig. $3 \mathrm{~A}$ and visualized with an antibody against TFPI $_{1-131}$. A major difference with the cleavage pattern seen in Fig. $2 \mathrm{~B}$ (the blot of unreduced samples that used an antibody against TFP $\left.\right|_{254-276}$ is the fast appearance of a protein band of $\sim 30 \mathrm{kDa}$. The $\mathrm{N}$-terminal amino acid sequencing of this cleavage product yielded two sequences: (M)DSEEDEEH and ANENRFYYN, which correspond to residues $1-8$ and $200-208$, respectively (Table 1). The peptide bond that is cleaved, $\mathrm{Arg}^{199}-\mathrm{Ala}^{200}$, is located within the Kunitz-3 domain. Because the two peptide chains are held together by disulfide bonds, it is quite remarkable to see that under non-reducing conditions, the cleavage product has an apparent molecular weight $(\sim 30 \mathrm{kDa})$ that is significantly lower than observed for uncleaved TFPI Reduction of the molecular weight because of an additional cleavage in the $\mathrm{C}$ terminal region is unlikely because none of the blots of non-reduced samples showed the appearance of a small fragment with the same time course of appearance as the $\sim 30 \mathrm{kDa}$ protein band. On the contrary, the simultaneous appearance of a $\sim 6 \mathrm{kDa}$ C-terminal pepticle recognized by anti-TFPI ${ }_{254-276}$ in reduced samples (Fig. $2 \mathrm{~A}$ ), and that of a $\sim 26 \mathrm{kDa} \mathrm{N}$-terminal peptide recognized by antiTFP| $\left.\right|_{1.161}$ in reduced samples (Fig. $3 \mathrm{~A}$ ) strongly supports the notion that the protein band that corresponds with $\sim 30 \mathrm{kDa}$ peptide is a two-chain TFPI with an intact $\mathrm{C}$ terminus. The late appearance of the anti TFPl $\left.\right|_{i-161}$ positive $\sim 8 \mathrm{kDa}$ (Fig. 3A/B) and $\sim 20 \mathrm{kDa}$ (Fig. 3B) fragments simultaneously with the appearance of a $\sim 26 \mathrm{kDa}$ fragment recognized by the antibodies against $T F P_{254-267}$ (Fig. 2B) indicates a further cleavage of the two-chain TFPI by FXa. The $\sim 8 \mathrm{kDa}$ fragment in Fig. $3 \mathrm{~A} / \mathrm{B}$ is not visible in Fig. $2 \mathrm{~A} / \mathrm{B}$ but appears simultaneously with the $\sim 20 \mathrm{kDa}$ fragment in Fig $3 \mathrm{~B}$ indicating that the $\sim 8 \mathrm{kDa}$ fragment represents an $\mathrm{N}$-terminal cleavage peptide. Thus besides a fast cleavage at $\mathrm{Arg}^{199}-\mathrm{Ala}^{200}$, resulting in two-chain TFPI, a slower cleavage somewhere between Kunitz- 1 and Kunitz-2 domain occurs. The $\mathrm{N}$-terminal amino acid sequencing of the $\sim 8 \mathrm{kDa}$ fragment seen in the immunoblot was impeded by the fact that the protein blot of reduced samples, after electrophoresis on a $16 \%$ SDS-PAA-gel, showed a triplet in the low molecular weight region. We could identify 


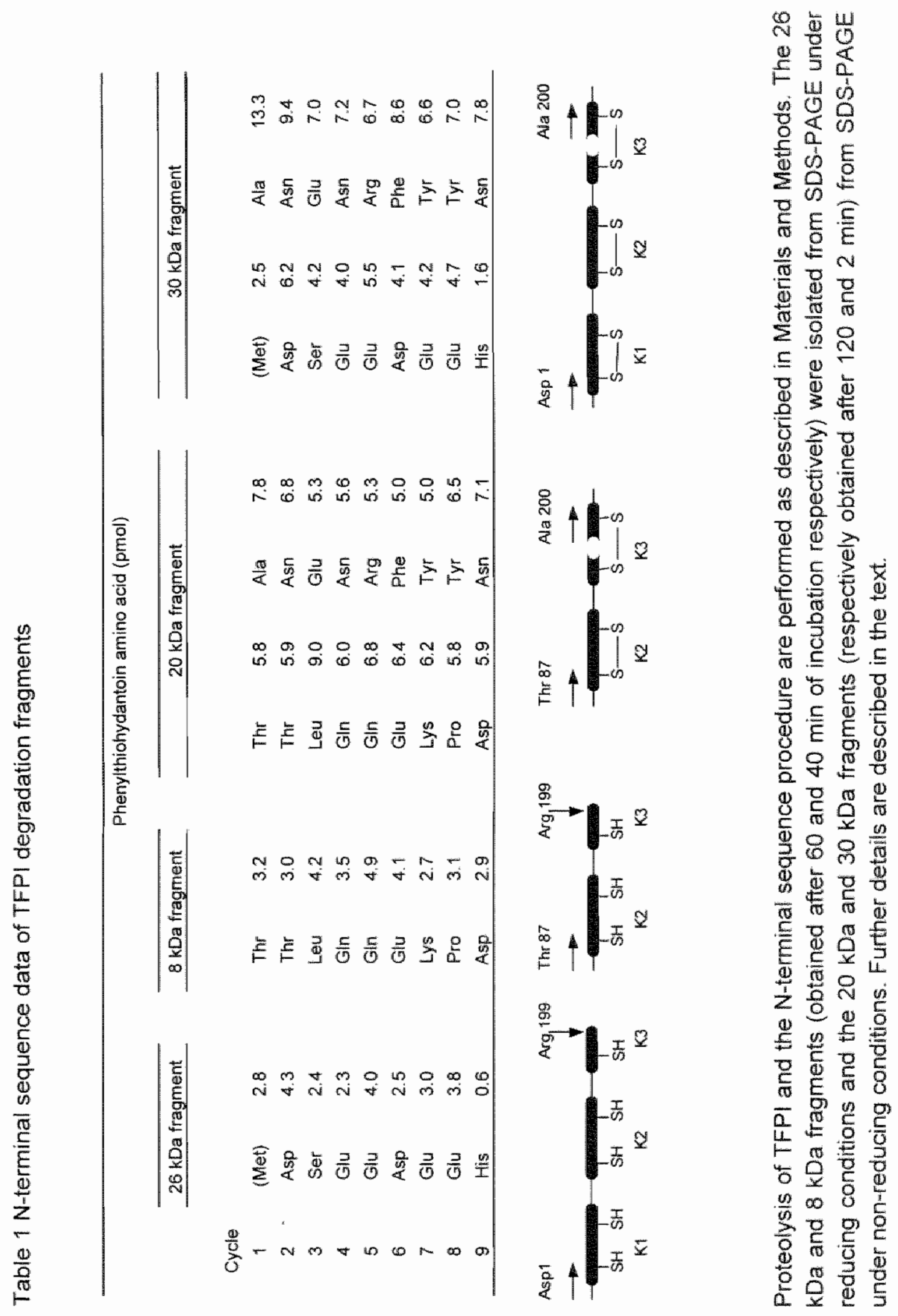


a peptide of $\sim 8 \mathrm{KDa}$ with TTLQQEKPD as the $\mathrm{N}$-terminal sequence (Table 1). The $\sim 20 \mathrm{kDa}$ fragment (Fig. 3B) presumably arising from the same cleavage, in contrast, could easily be isolated and yielded two sequences: TTLQQEKPD and ANENRFYYN. The first sequence corresponds to residues $87-95$ and the latter one corresponds to residues $200-208$ (Table 1). The $-26 \mathrm{kDa}$ fragment in Fig. $2 \mathrm{~B}$ has probably the same origin as the $-20 \mathrm{kDa}$ band in Fig $3 \mathrm{~B}$. That is, they both contain the Kunitz-2 domain and the $\mathrm{Arg}^{199}-\mathrm{Ala}^{200}$ cleaved Kunitz-3 domain. The $-20 \mathrm{kDa}$ band however, possibly also lacks its C-terminus because in the same time also the $\sim 3 \mathrm{kDa}$ fragment appears and a faint intermediate is observed in Fig. $3 \mathrm{~B}$ between the $-30 \mathrm{kDa}$ and $-20 \mathrm{kDa}$ band. This could explain why this $\sim 20 \mathrm{kDa}$ fragment is not visibile in Fig. $2 \mathrm{~B}$ since this blot is obtained with the antibody raised against the $\mathrm{C}$ terminus. In summary. FXa cleaves TFPI in the peptide bond between $\mathrm{Arg}^{199}$ and Ala $^{200}$ in Kunitz-3 and the peptide bond Lys ${ }^{86}-T_{h r}{ }^{87}$ between Kunitz-1 and Kunitz-2 We also found a cleavage at $\mathrm{Lys}^{249}{ }^{2} \mathrm{Gly}{ }^{250}$ and/or $\mathrm{Arg}^{246}-11 \mathrm{e}^{247}$, but the rates of these cleavages were relatively slow compared to the cleavage at $\mathrm{Arg}^{199}-\mathrm{Ala}^{200}$.

The Effect of Proteolysis on the Anticoagulant Activity of TFPI. To assess the loss of anticoagulant activity of TFPI upon FXa-dependent proteolysis, we used a dilute TF clotting assay in which the TF dilution was such that normal plasma has a clotting time of 200 s. Fig. 4 shows that the coagulation time increases linearly with increasing concentrations of (truncated-)TFPI whether or not in a preformed complex with FXa. Table 2 summarizes the prolongation of the clotting time in seconds when $1 \mathrm{nM}$ (truncated-)TFPI or preformed FXa: (truncated-)TFPI complex is added to the assay. Noteworthy is the negligible anticoagulant effect of TFPI alone, compared to its complex with FXa. It is apparent that the anticoagulant activities of preformed FXa:TFPI $\left.\right|_{1-16}$ and FXa:TFP| $\left.\right|_{1-250}$ complexes are 2-3 fold lower than of the complex of FXa with full length TFPI.

When preformed FXa:TFPI complex (50 nM TFPI plus 75 nM FXa) was incubated with PSPC (5 $\mu \mathrm{M}$ ) in Tris-buffer containing $5 \mathrm{mM} \mathrm{CaCl} \mathrm{C}_{2}$ the measured anticoagulant activity in timed samples shows a biphasic disappearance (Fig. 5). An initial rapid decrease of about $50 \%$ within $5 \mathrm{~min}$ is followed by a continuing decline, eventually leading to complete loss of anticoagulant activity. As expected, when the negatively charged phospholipid vesicles in the incubation mixture were replaced by PC vesicles, the anticoagulant activity of the FXa:TFPI complex remained unchanged. Immunoblot analysis of reduced samples taken from the incubation mixture containing $\mathrm{PC}$ vesicles confirmed that TFPI was not cleaved at the peptide bond Arg ${ }^{199}-$ Ala $^{200}$, Lys ${ }^{36}-$ Thr $^{87}$, Lys ${ }^{249}-$ Gly $^{250}$ and/or Arg ${ }^{246}-11 e^{247}$ (data not shown).

A comparison between the time dependency of the loss of anticoagulant activity (Fig. 5) and the cleavage patterns shown in Figs. 2 and 3 , makes it possible to associate the loss of inhibitory activity of the preformed FXa:TFPI complex in the dilute TF assay with specific peptide bond cleavages. The rapid cleavage of the 


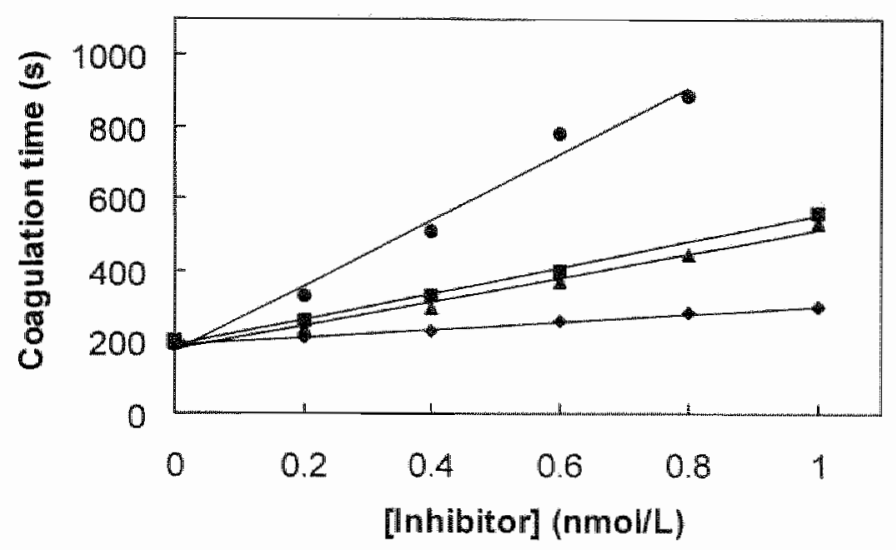

Figure 4. Effect of TFPI and preformed FXa:TFPI complexes on dilute TF clotting

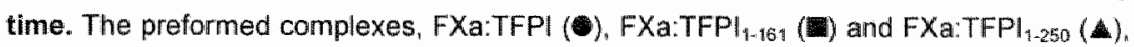
or free TFPI ( were added to the assay system at the indicated concentrations. Further details are described under Materials and Methods.

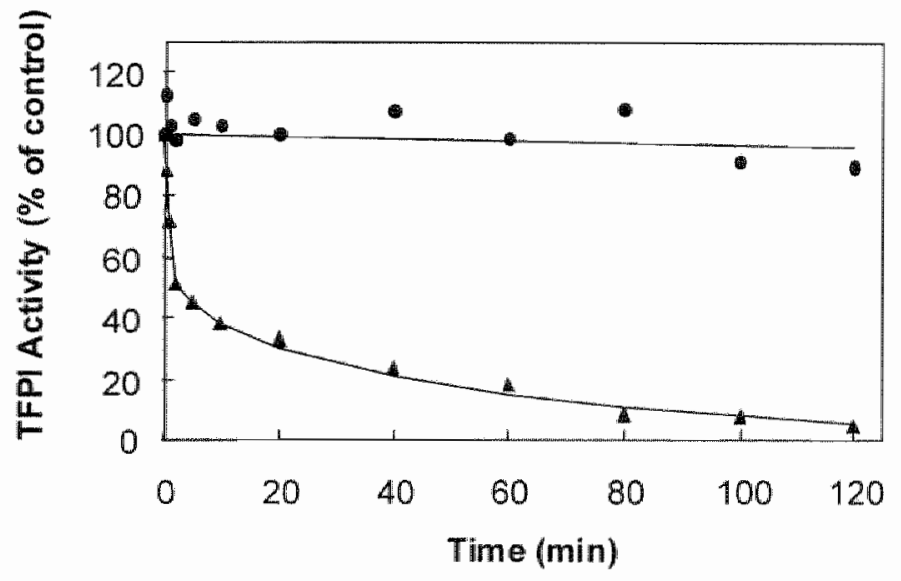

Figure 5. Effect of FXa cleavage on the anticoagulant activity of TFPI. Samples of the incubation mixtures of Fig. 3 were used to measure the anticoagulant activity of preformed FXa:TFPI complexes incubated with $5 \mu \mathrm{M}$ PSPC (M) ar $5 \mu \mathrm{M}$ PC (1) with the dilute TF clotting assay. 
Arg ${ }^{199}-\mathrm{Ala}^{200}$ peptide bond in the Kunitz-3 domain results in $50-70 \%$ loss of the anticoagulant activity of the preformed FXa:TFPI complex. Complete loss of anticoagulant activity could be attributed to the ensuing, slowly progressing cleavage of the peptide bond Lys ${ }^{86}-\mathrm{Thr}^{87}$ between the Kunitz-1 and Kunitz-2 domain. We thus clearly demonstrated that cleavage of $\mathrm{Arg}^{199}-\mathrm{Ala}^{200}$ also reduces the anticoagulant activity of the preformed FXa:TFPI complex. This in addition to the common knowledge that loss of anticoagulant activity of TFPI is associated with truncation of TFPI at the C-terminus. Interestingly, the residual activity of this FXa:two-chain TFPI complex is similar to that of $\mathrm{FXa}$ in complex with C-terminal truncated variants of TFPI (Table 2).

Table 2 Prolongation of the clotting time upon addition of TFPI or FXa:TFPI complexes to the dilute TF assay.

\begin{tabular}{lc}
\hline Inhibitor & Prolongation of the clotting time * \\
\hline FXa:TFPI $_{1-161}$ & (seconds/nM) \\
FXa:TFP| $_{1-250}$ & 360 \\
FXa:TPFI $_{\text {TFPI }}$ & 340 \\
TFPI $_{1-250}$ & 1000 \\
TFPI & 7 \\
\hline
\end{tabular}

Calculated from slopes as shown in Fig. 4 .

The Effect of Proteolysis on the Anti-TFiFVIIa Activity. We extended our investigation on the neutralization of the inhibitory activity of FXa:TFPI upon proteolysis with an assay on the inhibition of the TF:FVIla catalyzed activation of $F X$ by the preformed FXa:TFPI complexes. Fig. 6 A shows the generation of FXa, both in the absence and presence of various concentrations of preformed FXa:TFPI complex, as a function of the incubation time. It is shown that the plateau value of FXa formed, decreases with increasing concentrations of FXa:TFPI complex. Plateau values were measured in a range from 0 to $2.5 \mathrm{nM} F X a: T F P I$ and were replotted in Fig. 6B which shows the relationship between the extent of inhibition of FX activation and the concentration of preformed FXa:TFPI complex.

Incubation of preformed complex (50 nM TFPI plus $75 \mathrm{nM} \mathrm{FXa)} \mathrm{with} \mathrm{PSPC} \mathrm{(5}$ $M$ M) in Tris-buffer containing $5 \mathrm{mM} \mathrm{CaCl}$ resulted in a decrease of FXa:TFPI inhibitory activity towards TF:FVlla (Fig. 7). It is evident that the FXa:TFPI complex retains its inhibitory activity when incubated with $\mathrm{PC}$ vesicles. A comparison of the 

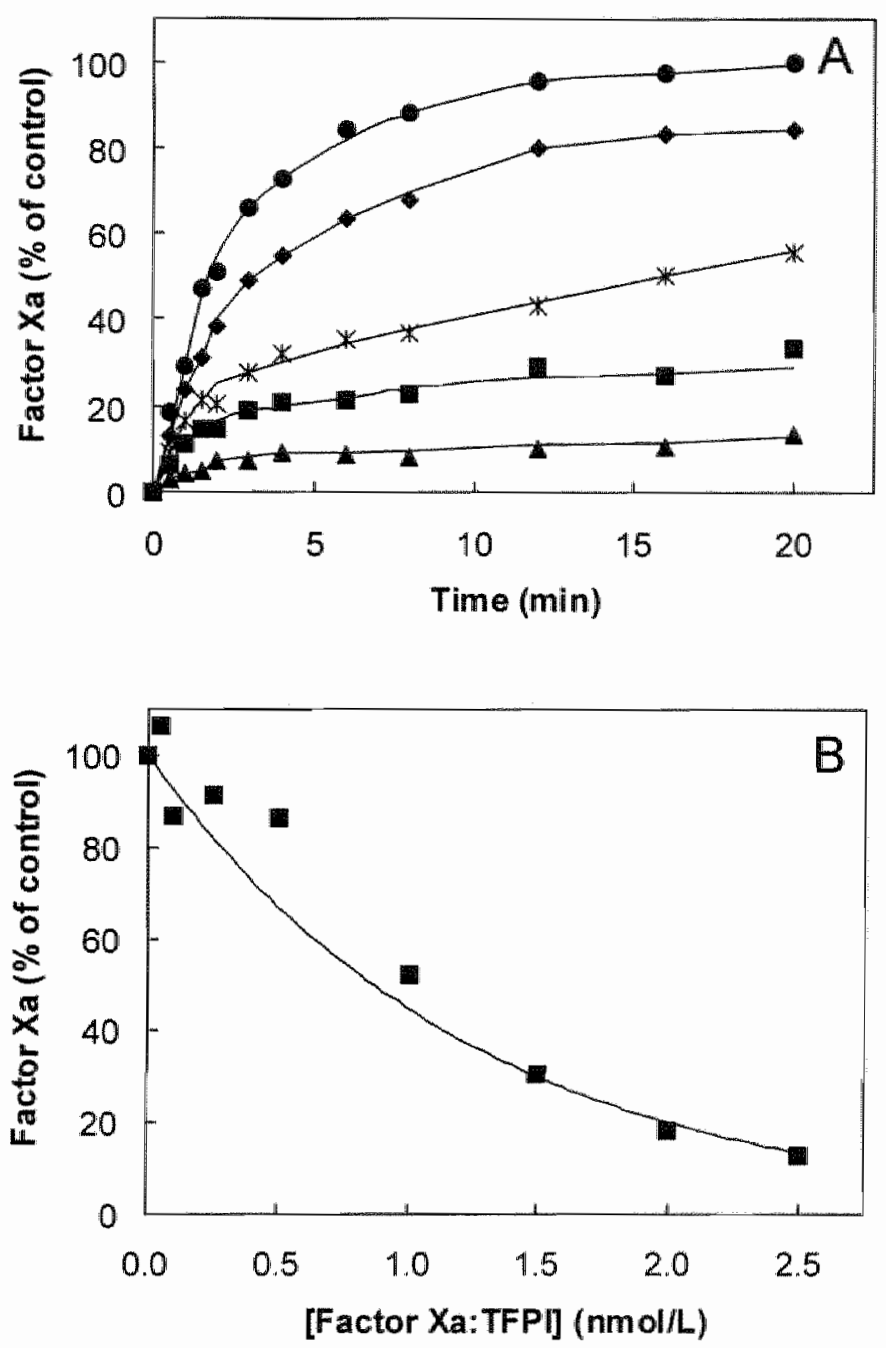

Figure 6. Effect of preformed FXa:TFPI complex on TF:FVlla catalyzed FX activation. Panel A. FX (100 nM) was incubated with TF $(0.1 \mathrm{nM}), 10 \mu \mathrm{M}$ PSPC and $1 \mathrm{nM}$ FVlla in the absence () or presence of varying amounts (0-2.5 nM) FXa:TFPI. Shown are: $0.5 \mathrm{nM}$ (*). $1.0 \mathrm{nM}(*), 1.5 \mathrm{nM}(\mathbf{B}), 2.5 \mathrm{nM}(\mathbf{\Delta})$. Samples were removed at indicated time points and assayed for FXa. Panel B: Averaged amounts of FXa measured between 12 and 20 min versus the FXa:TFPI complex concentration. 


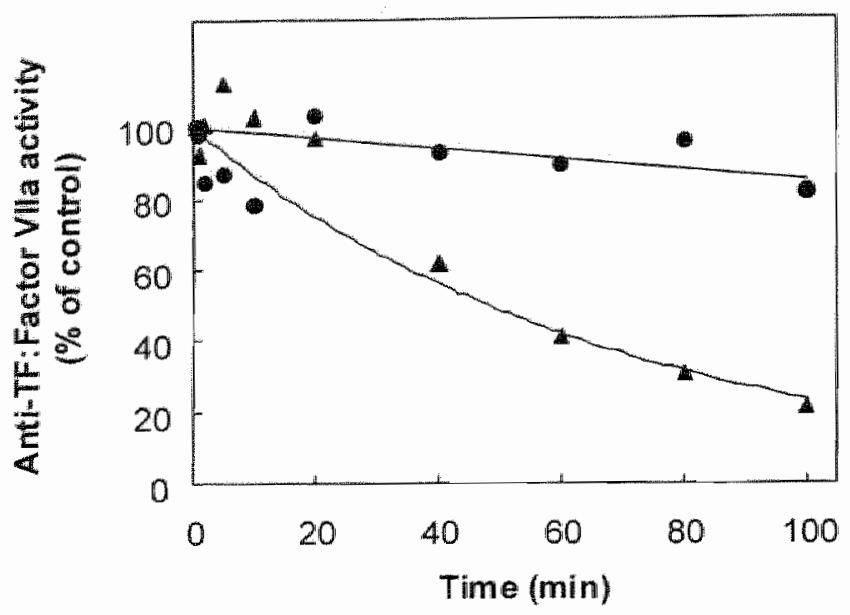

Figure 7. Effect of FXa cleavage on the anti-TF:FVlla activity of TFPl. Timed samples from the PSPC ( $\Delta$ ) or PC (-) incubations of Fig. 3 were added to the FX activation mixtures of Fig. 6. Plotted are the residual TFPI activities (calculated from the plateau values of FXa and Fig. $6 \mathrm{~B}$ ) as a percentage of the control (FXa:TFPI incubated in the absence of PSPC vesicles) wersus the incubation time of the FXa, TFPI and phospholipid mixtures.

time dependency of the inhibition of TF:FVlla activity (Fig. 7) with the Western blot data of Figs. $3 A$ and $B$, indicates that the cleavage in the Kunitz-3 domain has no effect on the anti TF:FVIla activity. This in contrast to the effect the $\mathrm{Arg}^{199}-\mathrm{Ala}^{200}$ cleavage exerts on the anticoagulant activity of TFPI as observed in Fig. 5 . In fact, the gradual decline of the anti TF:FVIla activity seems to be related to the cleavage of the peptide bond $\mathrm{Lys}^{86}-\mathrm{Thr}^{87}$ between the Kunitz-1 and Kunitz-2 domain. This observation confirms earlier reports that showed that a cleavage between the Kunitz1 and Kunitz-2 domain destroys the anti TF:FVIla inhibitory activity of TFPI $(18,19)$.

Proteolysis of TFPI and Its Anti-FXa Activity. The loss of anticoagulant activity and anti-TF:FVIla activity after cleavage of a peptide bond between the first and second Kunitz domain could also result from dissociation of FXa from the cleaved $T F P \mid$ as reported by other investigators $(18,19)$. We, however observed that during the incubation of FXa $(75 \mathrm{nM})$ and TFPI $(50 \mathrm{nM})$ in the presence of PSPC, as in Fig. 5 , the FXa activity dropped within 5 min to a residual activity that corresponds with 25 nM free FXa. Upon prolonged incubation (120 min) only a slight increase of 5\% free FXa was measured. Thus in contrast with others we found that the active site of FXa remains blocked by TFPI in spite of the cleavage of TFPI between the Kunitz-1 and Kunitz-2 domain. 


\section{Discussion}

Here, we report studies on the FXa mediated proteolysis of TFPI in complex with FXa and the concomitant loss of the inhibitory activity of this complex. It was shown that the rate of proteolysis is proportional to the free $F X a$ concentration and that it is greatly enhanced by the presence of a negatively charged phospholipid surface. Proteolysis of TFPI abollshed the ability of TFPI to inhibit TF: FVIlla mediated FX activation as well as the anticoagulant activity of the FXa:TFPI complex in a dilute TF clotting assay.

Three cleavage sites were identified, namely between the Kunitz-1 and Kunitz-2 domain (Lys ${ }^{86}-$ Thr $^{87}$ ), in the C-terminus at Lys ${ }^{249}-$ Gly $^{250}$ and/or $\mathrm{Arg}^{246}-11 \mathrm{e}^{247}$ and within the Kunitz-3 domain $\left(\mathrm{Arg}^{199}-\mathrm{Ala}^{200}\right)$. The $\mathrm{Lys}^{86}-\mathrm{Thr}^{87}$ cleavage has also been described very recently in relation to thrombin-mediated proteolysis of TFPI (30) and differs only one amino acid with the $\mathrm{Thr}^{87}-\mathrm{Thr}^{88}$ cleavage in TFPI reported for human leukocyte elastase $(18,19)$. The $\mathrm{Arg}^{199}-\mathrm{Ala}^{200}$ cleavage site is reported there for the firs time and is of special interest because the Arg ${ }^{199}$ is the so-called $P_{1}$ residue of the third Kunitz type protease inhibitor domain (31) of which the physiological role is not known. The cleavage of the $\mathrm{Arg}^{199}-\mathrm{Ala}{ }^{200}$ peptide bond appeared to be much faster than that of the Lys ${ }^{86}-$ Thr $^{87}$ bond. It remains however to be established whether the cleavages $\mathrm{Arg}^{199}-\mathrm{Ala}^{200}$ and $\mathrm{Lys}^{86}-\mathrm{Thr}^{87}$ occur at random with different rates or in a sequential order. In this respect it should be noted that Ohkura et all (30) report three thrombin cleavage sites in TFPl; Lys ${ }^{254}-\mathrm{Thr}^{255}, \mathrm{Arg}^{107}-\mathrm{Gly}^{108}$ and $\mathrm{Lys}^{86}$. $\mathrm{Thr}^{87}$ which are claimed to occur in that order.

Cleavage of TFPI within the Kunitz-3 domain at $\mathrm{Arg}^{199}-\mathrm{Ala}^{200}$ results in a twochain form of TFPI as established by $\mathrm{N}$-terminal sequencing. Remarkably though is the size reduction from 36 to $30 \mathrm{kDa}$, observed on the Westerm blot under nonreducing conditions using antibodies against TFP| $\|_{-161}$ (Fig. 3B). This observation suggests a further cleavage in the C-terminal tail. However, the Western blots in which an antibody against the C-terminal tail was used, did not reveal a $\mathrm{C}$-terminal truncation in the same time course of the abundant appearance of the $30 \mathrm{KDa}$ peptide. Therefore we assume that the $\sim 30 \mathrm{kDa}$ fragment is in fact full length TFPI but with an altered electrophoretic mobility. A close look at Fig. $2 \mathrm{~B}$ reveals a faint doublet in the $36 \mathrm{kDa}$ region which, taking into account the lower resolution for gradient SDS-PAGE, might point at the same two-chain form of TFPI, also migrating with a different mobility compared to the uncleaved TFPI. This observed abnormality in electrophoretic mobility could be due to a strongly altered protein conformation induced by cleavage of the $\mathrm{Arg}^{199}-\mathrm{Ala}^{200}$ bond. We note that a shift in electrophoretic mobility on SDS-PAGE under non-reducing conditions due to conformational changes has been demonstrated for a number of proteins (32-34). A dramatic conformational change upon cleavage of the peptide bond in the Kunitz-3 domain could also explain why the two-chain TFPI is hardly visible on the blot that used 
antibodies against the C-terminal region of TFPI. Again, hampering of epitope recognition upon a conformational change has been reported previously (33). It is tempting to speculate that the conformational change as a result of the cleavage within the Kunitz-3 domain enables an interaction between the negatively charged $\mathrm{N}$ terminal and positively charged C-terminal regions.

It is of interest to see that cleavage of the $\mathrm{Arg}^{199}-\mathrm{Ala}^{200}$ peptide bond in TFPI also causes functional changes in the molecule. We previously reported that the phospholipid-dependent and FXa-mediated partial proteolysis of TFPI caused a dramatic reduction in the affinity of the FXa:TFPl complex for negatively charged phospholipids (17). The present study has demonstrated that this loss in binding affinity is due to the cleavage of the $\mathrm{Arg}^{199}-\mathrm{Ala}^{200}$ bond. Speculating about the mechanism that causes this loss in binding affinity we suggest that the aforementioned cleavage-induced conformational change in TFPI prohibits the $\mathrm{C}$ terminal chain of TFPI from interacting with the negatively charged phospholipid membrane. Recent work reported by Kazama et al (35) suggests that negatively charged phospholipids are essential to the anticoagulant activity of the FXa:TFPI complex. This phospholipid requirement provides an interesting explanation for the partial loss of anticoagulant activity that was associated with the cleavage of the Arg $^{199}-\mathrm{Ala}^{200}$ bond in TFPI. In this respect it is also interesting to see that the anticoagulant activity of preformed complexes of FXa with C-terminal truncated TFPI (TFPI ${ }_{1-161}$ and $\mathrm{TFPI}_{1-250}$ ), having a low affinity for negatively charged phospholipids (17), showed the same reduction in anticoagulant activity as the $\mathrm{Arg}^{199}-\mathrm{Ala}^{200}$ cleaved TFPI in complex with FXa. These observations are the more intriguing because cleavage at $\mathrm{Arg}^{199}$-Ala ${ }^{200}$ seems to leave the inhibitory activity towards TF:FVlla activity in a purified system unaltered. Other studies have shown that, unlike free TFPI, preformed FXa:TFPI complexes inhibit the TF:FVIla activity in a purified system with the same rate irrespective of the presence of the Kunitz-3 domain and the positively charged C-terminus $(14,15)$. Thus, once the complex between FXa and TFPI is formed, structural alterations in the C-terminal region like truncation or cleavage at $\mathrm{Arg}^{199}-\mathrm{Ala}^{200}$, have no effect on the inhibitory activity towards TF.FVIla. At present we have no explanation for the apparent lack of correlation between anti-TF:FVIla activity in a purified system and anticoagulant activity. However, it appears that in a plasma environment the interaction between negatively charged phosphollipids and FXa:TFPI is more important for the inactivation of TF.FVIla activity than in a buffer system with purified proteins.

Cleavage between the Kunitz-1 and Kunitz-2 domain at the Lys ${ }^{86}-$ Thr $^{87}$ peptide bond dissociates the FXa binding region from the FVIlla binding region. Since the simultaneous interaction of TFPI with both FXa and FVIla is essential to inhibit TF:FVIla activity, it is not surprising that this cleavage results in a complete annihilation of the anticoagulant activity of the FXa:TFPI complex $(18,19,30)$. Furthermore, proteolysis of TFPI in complex with FXa at the Lys ${ }^{86}-\mathrm{Thr}^{87}$ peptide bond 
does not result in recovery of FXa activity, suggesting that FXa remains complexed with two-chain TFPI that lacks the Kunitz-1 domain. Omission of the Kunitz-1 domain is obviously sufficient to abrogate the inhibitory activity of the FXa:TFPI complex.

Our findings suggest that FXa might have a dual function in its own. TFPIcontrolled, generation. That is, FXa in complex with TFPl, rapidly inactivates TF:FVlla catalyzed FX activation. But at the same time and at the same membrane, the anticoagulant activity of the FXa:TFPI complex is rapidly neutralized by FXa that is not inactivated by TFPI.

\section{References}

1. Broze GJ Jr, Girard TJ and Novotny WF (1990) Regulation of coagulation by a multivalent Kunitztype inhibitor. Biochemistry 29,7539-46.

2. Rapaport SI (1991) The extrinsic pathway inhibitor: A regulator of tissue factor-dependent blood coagulation. Thromb Haemost 66, 6-15.

3. Broze GJ Jr, Warren LA, Novotny WF, Higuchi DA, Girard JJ and Miletich JP (1988) The lipoprotein-associated coagulation inhibitor that inhibits the factor VII-tissue factor complex also inhibits factor Xa: Insight into its possible mechanism of action. Blood 71, 335-43.

4. Novotny WF, Girard TJ, Miletich JP and Broze GJ Jr (1989) Purification and characterization of the lipoprotein-associated coagulation inhibitor from human plasma. J Biol Chem 264, 18832-7.

5. Wun TC, Kretzmer KK, Girard TJ, Mietich JP and Broze GJ Jr (1988) Cloning and characterization of a CDNA coding for the lipoprotein-associated coagulation inhibitor shows that it consists of three tandem Kunitz-type inhibitory domains. J Biol Chem 263,6001-4.

6. Huang $Z_{7}$, Wun TC and Broze GJ Jr (1993) Kinetics of Factor-Xa inhibition by tissue factor pathway inhibitor. J Biol Chem 268, 26950-5.

7. Girard TJ, Warren LA, Novotny WF, Likert KM, Brown SG, Miletich JP and Broze GJ Jr (1989) Functional significance of the Kunitz-type inhibitory domains of lipoprotein-associated coagulation inhibitor. Nature 338, 518-20.

8. Petersen LC, Bjorn SE, Olsen OH, Nordfang O, Norris. F and Norris K (1996) Inhibitory properties of separate recombinant Kunitz-type-protease-inhibitor domains from tissue factor pathway inhibitor. Eur J Biochem 235, 310-6.

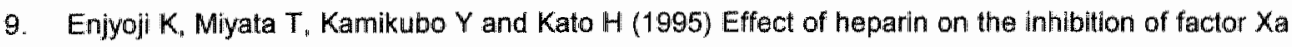
by tissue factor pathway inhibitor: a segment, Gly212-Phe243, of the third Kunitz domain is a heparin-binding site. Biochemistry 34, 5725-35.

10. Valentin $S$. Nordfang $O$, Bregengärd $C$ and Wildgoose $P$ (1993) Evidence that the C-terminus of tissue factor pathway inhibitor (TFPI) is essential for its in vitro and in vivo interaction with lipoproteins. Blood Coag Filbrinol 4, 713-20.

11. Nordfang O, Björn SE, Valentin S, Nielsen LS, Wildgoose P. Beck TC and Hedner U (1991) The C-terminus of tissue factor pathway inhibitor is essential to its anticoagulant activity. Blochemistry $30,10371-6$. 
12. Wesselschmidt R. Likert $K$ Girard T. Wur TC and Broze GJ Ir (1992) Tissue factor pathway inhibitor: The carboxy-terminus is required for optimal inhibition of factor Xa. Blood $79,2004-10$

13. Lindhout $T$. Willems $G$, Blezer $R$ and Hemker HC (1994) Kinetics of the intibition of human factor $X a$ by full-length and truncated recombinanit tissue factor pathway inhibitor. Biochem $J 297,131-6$.

14. Lindhout $T$, Franssen $J$ and Willems $G(1995)$ Kinetics of the inhibition of tissue factor-factor Vlla by tissue factor pathway inhibitor. Thromb Haemost $74,910-5$.

15. Jesty J. Wun TC and Lorenz A (1994) Kinetics of the irthibition of factor $X a$ and the tissue factorfactor Vlla complex by the tissue factor pathway inhibitor in the presence and absence of heparin. Biochemistry $33,12686-94$.

16. Valentin $S$ and Schousboe I (1996) Factor Xa enhances the binding of tissue factor pathway inthibitor to acidic phospholipids. Thromb Haemost 75, 796-800.

17. Willems GM, Janssen MP, Salemink I, Wun T-C and Lindhout T (1998) Transient high affinity binding of tissue factor pathway inhibitor-Factor Xa complexes to negatively charged phospholipid membranes. Biochemistry 37, 3321-8.

18. Higuchi DA, Wun TC, Likert KM and Broze GJ Jr (1992) The effect of leukocyte elastase on tissue factor pathway inhibitor. Blood 79, 1712-9.

19. Petersen LC, Björn SE and Nordfang O (1992) Effect of leukocyte proteinases on tissue factor pathway inhibitor. Thromb Haemost 67, 537-41.

20. Mertens $K$ and Bertina RM (1980) Pathways in the acifivation of human coagulation factor $X$. Biochem J 185, 647-58.

21. Lindhout MJ, Kop-Klaassen BH and Hemker HC (1978) Activation of decarboxyfactor $X$ by a protein from Russell's viper venom. Purification and partial characterization of activated decarboxyfactor X. Biochim Biophys Acta 533, 327-41.

22. Smith RL (1973) Titration of activated bovine Factor X. J Biol Chem 248, 2418-23.

23. Diaz-Collier JA, Palmier MO, Kretzmer KK, Bishop BF, Combs RG, Obukowicz MG, Frazier RB, Bild GS, Joy WD, Hill SR and et al. (1994) Refold and characterization of recombinant tissue factor pathway inhibitor expressed in Escherichia calk. Thromb Haemost 71, 339-46.

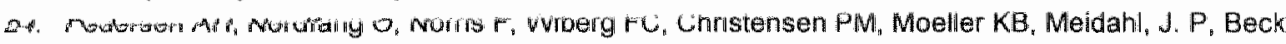
TC. Norris K, Hedner U and Kisiel W (1990) Recombinant human extrinsic pathway inhibitor. Production. isolation, and characterization of its inhibitory activity on tissue factor-initiated coagulation reactions. J Biol Chem 265, 16786-93.

25. Petersen JG, Meyn $G$, Rasmussen JS, Petersen $J$. Bjöm SE, Jonassen 1, Christiansen L and Nordfang $O$ (1993) Characterization of human tissue factor pathway inhibitor variants expressed in Saccharomyces cerevistae. J Biol Chem 268, 133444-51.

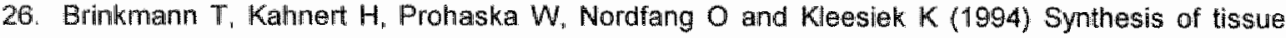
factor pathway inhibitor in human synovial celis and chondrocytes makes joints the predilected site of bleeding in haemophiliacs. Eur J Clin Chem Clin Biochem 32, 313-7.

27. Erhardisen E, Ezban M, Madsen MT. Diness $W$, Glazer $S$, Hedner U and Nordfang $O$ (1995) blocking of tissue factor pathway inhibitor (TFPI) shortens the bleeding time in rabbits with antibody-induced hemophilia-A. Blood Coag Fibrinol 6, 388-94. 
28. Rosing J, Bakker HM, Thomassen MCLGD, Hemker HC and Tans $G$ (1993) Characterization of two forms of human factor Va with different cofactor activities. J Biol Chem 268, 21130-6.

29. Laemmli MK (1970) Cleavage of structural proteins during the assembly of the head bacteriophage T4. Nature 227,680-5.

30. Onkura N, Enjyoji KI, Kamikubo $Y$ and Kato H (1997) A novel degradlation pathway of tissue factor pathway inhibitor: incorporation into fibrin clot and degradation by thrombin. Blood $90,1883-92$.

31. Gebhard $W$ and Hochstrasser $K$. Inter-a-trypsin inhibitor and its close relatives. In: In Barrel A.J Salvesen Ge, eds. Protease inhibitors, Amsterdami Elsevier, 1986: 389.

32. Owen WG, Esmon CT and Jackson GM (1974) The conversion of prothrombin to thrombin I. Characterization of the reaction products formed during the activation of bovine prothrombir. $J$ Biol Chem 249, 594-605.

33. Olds RJ, Lane DA, Caso R, Panico M, Morris HR, Sas G, Dawes J and Thein SL (1992) Antithrombin III Budapest: A single amino acid substitution (429Pro to Leu) in a region highly conserved in the serpin family. Blood 79, 1206-12.

34. Harrison HH, Gordon ED, Nichols WC and Benson MD (1991) Biochemical and clinical characterization of prealbuminCHICAGO: An apparently benign variant of serum prealbumin (transthyretin) discovered with high-resolution two-dimensional electrophoresis. Am J Med Genet $39,442-52$.

35. Kazama $Y(1997)$ The importance of the binding of factor $X a$ to phospholipids in the inhibitory mechanism of tissue factor pathway inhibitor: The transmembrane and cytoplasmic domains of Tissue Factor are not essential for the inhibitory action of tissue factor pathway inhibitor. Thromb Haemost 77, 492-7. 


\title{
Chapter 4
}

\author{
Inhibition of Tissue Factor:Factor Vlla Catalyzed Factor X Activation by Factor \\ Xa:Tissue Factor Pathway Inhibitor: A Rotating Disc Study on the Effect of \\ Phospholipid Membrane Composition
}

Irene Salemink, Jo Franssen, George M. Willems, H. Coenraad Hemker and Theo Lindhout (1999) The Journal of Biological Chemistry 274, 28225-28232

\section{Summary}

The physiological inhibitor of Tissue Factor (TF):factor Vlla (FVlla), full length tissue factor pathway inhibitor (TFPI $\mathrm{FL}_{\text {) }}$ in complex with factor $\mathrm{Xa}(\mathrm{FXa})$, has a high affinity for anionic phospholipid membranes. The role of anionic phospholipids in the inhibition of TF:FVlla-catalyzed FX activation was investigated. FXa generation at a rotating disc coated with TF embedded in a membrane composed of pure phosphatidylcholine (TF:PC) or $25 \%$ phosphatidylserine and $75 \%$ phosphatidylcholine (TF:PSPC) was measured in the presence of preformed complexes of FXa:TFPl $F L$ or FXa:TFPI $_{1-161}$ (TFPI lacking the third Kunitz domain and C-terminus). At TF:PC, FXa:TFPI $\left.\right|_{F L}$ and $F X: T_{F P I}{ }_{1-161}$ showed similar rate constants of inhibition $\left(0.07 \times 10^{8} \mathrm{M}^{-1} \mathrm{~s}^{-1}\right.$ and $0.1 \times 10^{8} \mathrm{M}^{-1} \mathrm{~s}^{-1}$, respectively). With phosphatidylserine present, the rate constant of inhibition for FXa:TFPl $\mathrm{FL}_{\mathrm{L}}$ increased 3 -fold compared to a 9-folld increase in the rate constant for FXa:TFP| $\left.\right|_{1-161}$. Incubation of TF:PSPC with FXa:TFPI $F$ in the absence of FVlla followed by depletion of solution FXa:TFPI $F$ showed that FXa:TFPl $F_{L}$ remained bound at the membrane and pursued its inhibitory activity. This was not observed with FXa:TFPI ${ }_{1-161}$ or at TF:PC membranes. These data suggest that the membrane bound pool of FXa:TFPlFL may be of physiological importance in an on-site regulation of TF:FVIla activity. 


\section{Introduction}

Blood coagulation in vivo is initiated when circulating factor VIl(a) binds in a calcium dependent way to its cofactor, tissue factor (TF) (see $(1,2)$ for a review). This complex formation results in enhanced catalytic activity of factor Vila (FVlla). which via limited proteolysis, activates factors $X(F X)$ and $I X$ (FIX) (3). TF is a transmembrane glycoprotein which under normal conditions is expressed only in extravascular tissues $(4,5)$.

The main physiological regulator of TF-induced blood coagulation is tissue factor pathway inhibitor (TFPI) $(6,7)$, a single chain glycoprotein of $42 \mathrm{kDa}$ and a member of the Kunitz family of serine protease inhibitors. TFPI contains an acidic Nterminus, followed by three tandemly repeated Kunitz-type inhibition domains and a basic $\mathrm{C}$-terminal tail ( 8 ). Site directed mutagenesis has revealed that the first Kunitz domain binds to FVIla and that the second Kunitz domain interacts with the active site of FXa (9). No such functions could be attributed to the third Kunitz domain (10). Yet, various interactions have been ascribed to this domain, e.g. With lipoproteins and heparin, but their importance for the inhibitory function of TFPI is not clear (11. 12). On the other hand, the basic C-terminal region of TFPI (residues 240-276) has been shown to play a crucial role in the anticoagulant activity of this inhibitor $(13,14)$. Despite numerous studies, it remains unclear how this basic $\mathrm{C}$-terminus modulates the anticoagulant activity of TFPI (15-19).

TFPI inhibits the generation of FXa and FIXa by the TF:FVIla complex in a unique, two-step reaction (20). First, TFPI binds $\mathrm{Ca}^{2+}$ independently to FXa, thereby inhibiting the FXa catalytic activity (9). In a second step the FXa:TFPI complex binds in a $\mathrm{Ca}^{2+}$ dependent way to TF:FVIla. This results in the formation of the quaternary complex TF:FVIla:FXa:TFPI, in which the proteolytic activity of the TF:FVlla complex is fully neutralized. The effect of TFPI on TF:FVIla activity in the absence of FXa is negligible $(21,22)$, implying that the true inhibitor of TF:FVIla activity is the FXa:TFPI complex. The rate of complex formation of FXa and TFPI is enhanced by negatively charged phospholipids for full length TFPI (TFPIFL) but not for TFP| $\left.\right|_{1-161}$, a truncated variant lacking the third Kunitz domain and the potential phospholipid binding $C$ terminal tail $(16,23)$.

Recently (24), we demonstrated that TFPIFL in complex with FXa has a much higher affinity for anionic phospholipid membranes compared to that of either protein alone. It is well recognized that the binding of blood coagulation enzymes as well as their cofactors and substrates to membranes containing anionic phospholipids may result in an immense increase of the catalytic efficiency of these enzymes. On the other hand, excess-binding sites could cause a lowering of both solution concentration and surface density of the reactants $(25,26)$ resulting in a decrease of reaction rates. Previous studies $(17,22,23)$ did not reveal a stimulatory or interfering effect of anionic phospholipids on the complex formation between FXa:TFPI and 
TiF:FVlla. These studies, however, were performed in the presence of excess phospholipid vesicles. It remains unclear what the role is of lipid-protein interactions and of the TFPI C-terminus when TF is embedded in a macroscopic phospholipid membrane. Answering these questions could provide insight in the role of (TFbearing) cell membranes in the regulation of the TF:FVlla-catalyzed initiation of the blood coagulation process.

To mimic the processes occurring at TF bearing cell surfaces as closely as possible, we made use of TF embedded in a macroscopic phospholipid surface to which the reactants were supplied under well-defined flow conditions. This approach allows a quantitative study of the kinetics of inhibition of TF:FVIla-catalyzed FX activation as a function of the phospholipid composition of the membrane and the phospholipid-binding properties of the FXa:TFPI complex. Our study showed that negatively charged phospholipid surfaces act as a safety net in the sense that FXa:TFPI FL complexes readily bind to the surface. These phospholipid-bound FXa:TFPl $F L$ complexes then show a potent inhibitory activity against TF:FVlla present at the same membrane.

\section{Materials and Methods}

Materials. Bovine serum albumin (BSA, essentially fatty acid free) was obtained from Sigma (St. Louis, MO). The chromogenic substrate for FXa, S2765, was purchased from Chromogenix (Mölndal, Sweden). 1,2-Dioleoyl-sn-glycero-3phosphocholine (DOPC) and 1,2-dioleoyl-sn-glycero-3-phosphoserine (DOPS) were obtained from Avanti Polar Lipids (Alabaster, AL). All other reagents used were of analytical grade.

Proteins. Human FX was purified according to Mertens et al (27). Human FXa was prepared by activation of purified FX with the FX activating protein from Russell's Viper venom (Sigma, St. Louis, MO) and isolated as was described for bovine FXa (28). The molar concentration was determined by active site titration with p-nitrophenyl p-guanidinobenzoate hydrochloride (pNPGB) (29). Recombinant human TFPlfL, produced in Escherichia coli (30), was kindly supplied by Searle/Chiron (Emeryville, CA). This recombinant TFPIFL preparation, not being glycosylated, is very similar to the native highly glycosylated protein expressed in mammalian cells with respect to anticoagulant activity $(16,30)$. The C-terminal truncated TFPI preparation was kindly supplied by Dr. O. Nordfang (Novo Nordisk, Bagsvaerd, Denmark). TFPl ${ }_{1-16}$ was expressed in Saccharomyces cerevisiae and purified as described previously (31). The molar concentrations of the TFPI preparations were determined by titration with known amounts of FXa (18). Recombinant human TF was a kind gift of Dr. Y. Nemerson (Mount Sinai School of 
Medicine, New York, NY). Recombinant FVlla was a kind gift of Dr. U. Hedner (Novo Nordisk, Bagsvaerd, Denmark).

Relipidation of Recombinant Human TF. Recombinant human TF, 20 and 100 $\mathrm{nM}$, was reconstituted with $2 \mathrm{mM}$ PSPC (25 mol\% DOPS $/ 75 \mathrm{~mol} \%$ DOPC) and $2 \mathrm{mM}$ PC ( 100 mol\% DOPC) respectively, using n-octyl- $\beta$-D-glucopyranoside (Calbiochem, La Joilla, $C A$ ) solubilization and dialysis as described (32). Because the TF is randomly oriented in the reconstituted vesicles we considered the effective TF concentration to be $50 \%$ of the total concentration present in the reconstituted preparation (32). Calculations were therefore based on a TF:phospholipid ratio of $1: 20 \times 10^{4}$ and $1: 4 \times 10^{4}$ for $P S P C$ and $P C$ respectively.

The Rotating Disc Device. The set up used in the present study is a modification of the one described previously (33). In short, a cylinder (height $12 \mathrm{~mm}$, width 16 $\mathrm{mm}$ ) made of polyethylene terephtalate (PETP, AKZO Plastics. Amersioont The Netherlands), containing four tiny magnets, was mounted on a motor with servocontrolled rotation speed. A cylindrical vessel is placed on top of the motorcontaining holder, such that the cylinder rotates close to the glass bottom of the vessel. A glass cover slip (Menzel Gläser, Braunschweig, Germany) with a diameter of $20 \mathrm{~mm}$ is attached to another PETP cylinder (height $2 \mathrm{~mm}$, width $12 \mathrm{~mm}$ ) also containing four magnets. This second cylinder fits into a thin PETP ring, mounted in the vessel, which guides the movements of the rotating disc. A stationary baffle was immersed in the solution ( $3 \mathrm{~mL}$ ) during the experiments to establish a well-defined flow pattern.

Preparation of Phospholipid-Coated Discs. The glass cover slips of the rotating discs were made hydrophilic as previously described (34). In order to apply a TFcontaining lipid bilayer, the rotating discs $\left(63 \mathrm{rad} \mathrm{s}^{-1}\right)$ were exposed for $30 \mathrm{~min}$ to reconstituted vesicles in Tris buffer ( $50 \mathrm{mM}$ Tris- $\mathrm{HCl}, \mathrm{pH} 7.9$ and $175 \mathrm{mM} \mathrm{NaCl}$ ), with a final phospholipid-concentration of $20 \mu \mathrm{M}$. Fluid phase vesicles were removed by flushing for $5 \mathrm{~min}$ with TBSA-CaCl 2 buffer (Tris buffer containing $3 \mathrm{mM} \mathrm{CaCl}$ and 1 $\mathrm{mg} \mathrm{mL}^{-1} \mathrm{BSA}$ ) at a rate of $10 \mathrm{~mL} \mathrm{~min}^{-1}$ using a Minipuls II pump (Gilson, Villiers-leBel, France). Finally the disc was transported, without exposing the lipid surface to an air-buffer interface, to a second vessel that had been pretreated for 1 hour with 20 $\mathrm{mg} \mathrm{mL}^{-1} \mathrm{BSA}$ in Tris buffer. Before placing the coated disc in this second vessel, the high content BSA Tris buffer was replaced by $T B S A-\mathrm{CaCl}_{2}$ buffer. All preparations were performed at $37^{\circ} \mathrm{C}$. The effective TF surface density was $2.5 \mathrm{fmol} \mathrm{cm}{ }^{-2}$ and $12.5 \mathrm{fmol} \mathrm{cm}^{-2}$ for PSPC and PC respectively, as calculated on the basis of a phospholipid surface density of $0.5 \mathrm{nmol} \mathrm{cm}^{-2}$ and TF:phospholipid ratios of $1.20 \times 10^{4}$ or $1: 4 \times 10^{4}$. The disc surface area was $3.14 \mathrm{~cm}^{2}$, the theoretical amount of TF available at the surface is therefore 7.8 and $39 \mathrm{fmol}$ for PSPC and PC respectively. Throughout this paper, TF:PSPC and TF:PC refer to the planar surfaces thus obtained. 
Measurement of FX Activation. Discs coated with TF:PSPC or TF:PC were spun at $63 \mathrm{rad} \mathrm{s}^{-1}$ in $3 \mathrm{~mL}$ TBSA-CaCl 2 buffer. FVlla $(1 \mathrm{nM})$ was added and incubated with the spinning disc for $5 \mathrm{~min}$. The TF:FVlla activity was then assessed from FXa generation following the addition of $\mathrm{FX}(100 \mathrm{nM})$. Timed samples were taken from the reaction mixture and collected into polystyrene cuvettes containing $50 \mathrm{mM}$ Tris$\mathrm{HCl}, \mathrm{pH} 7.9,175 \mathrm{mM} \mathrm{NaCl}, 20 \mathrm{mM}$ EDTA and $0.5 \mathrm{mg} \mathrm{mL}^{-1} \mathrm{BSA}$, (total volume 450 $\mu \mathrm{L}$ ). To determine the amount of FXa present, $50 \mu \mathrm{L}$ of $3 \mathrm{mM}$ chromogenic substrate S2765 was added to the cuvette, and the conversion of the chromogenic substrate was followed at $37^{\circ} \mathrm{C}$ on a dual wavelength spectrophotometer at $405 \mathrm{~nm}$ (reference wavelength $500 \mathrm{~nm}$ ). The FXa concentrations were calculated from standard curves obtained with known amounts of the enzyme. The TF containing phospholipid surface of the rotating disc could be re-used after flushing with TBSA-EDTA buffer (20 mM EDTA) for 5 min at $10 \mathrm{~mL} \mathrm{~min}^{-1}$, followed by a rinse with TBSA-CaCl $\mathrm{Cl}_{2}$ buffer ( $5 \mathrm{~min}$ at $10 \mathrm{~mL} \mathrm{~min}{ }^{-1}$ ). All procedures were performed at $37^{\circ} \mathrm{C}$ and unless otherwise mentioned, at an angular velocity of $63 \mathrm{rad} \mathrm{s}^{-1}$.

Inhibition of TF:FVIIa Activity. All inhibition experiments were carried out with preformed FXa:TFPI complexes. These complexes were prepared by incubating FXa and TFPl at equimolar concentrations $(50 \mathrm{nM})$ for $30 \mathrm{~min}$ at $37{ }^{\circ} \mathrm{C}$ in $\mathrm{TBSA}-\mathrm{CaCl}_{2}$ buffer. This incubation time was sufficiently long to obtain an equilibrium in complex formation ( $95 \%$ of FXa in complex), as was established by measuring the free FXa concentration with chromogenic substrate S2765. The inhibitory activity of FXa:TFPI was assessed in two different ways. The first method was by pre-incubating TF:PSPC or TF:PC with FVlla (1 nM) for 5 min, then adding FX (100 nM) in the presence of various concentrations of FXa:TFPI and subsequently assaying the timed samples taken from the vessel for FXa activity. Under these conditions, fluid phase inhibitor complex is assumed to be in equilibrium with surface bound FXa:TFPI. The second method was by pre-incubating TF:PSPC or TF:PC for $10 \mathrm{~min}$ with $0.4 \mathrm{nM} \mathrm{FXa:TFPl}$, in the absence of FVIla, and then depleting the solution of inhibitor complex by flushing for various time intervals with $\mathrm{TBSA}-\mathrm{CaCl}_{2}$ buffer. Subsequently, FX activation was started by adding $F X(100 \mathrm{nM})$ and $F V / l a(1 \mathrm{nM})$ Timed samples were taken and assayed for FXa activity as described above.

\section{Data Analysis}

FVIIa Concentration-Dependent FX Activation. As the catalytic efficiency of FVIla in complex with TF is several orders of magnitude higher than that of free FVIla, the observed FX generation rate, $V_{\text {obs }}$, reflects the formation of the binary TF:FVlla complex and is described by the formula

$$
V_{\text {obs }}=V_{\max }[\mathrm{FV} \| \mathrm{la}] /\left([\mathrm{FV} \| \mathrm{la}]+K_{\mathrm{d}}\right)
$$


with [FVIla] the free FVIla concentration, $K_{0}$ the apparent dissociation constant of the TF:FVlla complex and $V_{\max }$ the FXa generation rate at saturating FVlla concentrations. As the amount of TF present in the system is negligible compared to the concentration of added FVIlla, [FVIla] equals the total FVIlla concentration. The parameters $V_{\text {max }}$ and $K_{d}$ were determined by least squares fitting of eq 1 to the measurements of $V_{\text {obs }}$.

Dependency of the FX Activation Rate on the FX Concentration. Measurements of the observed rate of FXa generation, Vobs, were analyzed using the MichaelisMenten formula

$$
V_{\text {obs }}=V_{\text {max }}[F X] /\left([F X]+K_{m, a p p}\right)
$$

which relates $V_{o b \text { s }}$ to $V_{\text {max }}$ the conversion rate at saturating $F X$ concentrations, [FX] the FX concentration, and $K_{m, a p p}$ the apparent Michaelis constant. The parameters $V_{\max }$ and $K_{m \text { mapp }}$ were determined by least squares fitting of eq 2 to the measurements of $V_{\text {obs. }}$. It should be noted that the substrate transport from the bulk solution to the disc surface depends on the concentration gradient between bulk and the solution, immediately adjacent to the catalytic surface. To what extent this substrate depletion near the surface causes an underestimation of the true $K_{m}$ value depends on the ratio of substrate conversion over the transport-limited rate of substrate supply (33).

Inhibition of TF:FVIIa-Mediated FX Activation by Preformed FXa:TFPI Complexes. The decrease in FX activation rate reflects the formation of quaternary TF:FVIlla:TFPI:FXa complexes and the corresponding decline of TF:FVIla activity, which for any fixed concentration of inhibitor, can be described as a pseudo-first order process $(22,23)$. Therefore, the time-dependent FXa generation indicating a mono-exponential decay of TF:FVIla activity can be expressed as

$$
[F \times a]_{t}=V_{0} / k\left(1-e^{-k t}\right)
$$

with [FXa], the observed FXa generation at time $t_{1} V_{0}$ the rate of FXa generation in the absence of inhibitor, $k$ the pseudo first order rate constant of inhibition and the reaction time. In principle, the rate constants $V_{0}$ and $k$ can be determined by a least squares fit of eq 3 to the FXa generation curve. This approach, however, is subject to the drawback that because of the rapid decline of the FXa generation rate the estimates of $V_{0}$ and $k$ become increasingly correlated and inaccurate for increasing concentrations of the inhibitory complex. To avoid this source of error we employed the excellent reproducibility of repeated measurements of FXa generation on the same TF:PSPC/TF:PC disc after regeneration by an EDTA wash (see Results section). Each measurement of FX activation in the presence of FXa:TFPI complex was preceded by a measurement of the corresponding FXa generation in the absence of inhibitor complex. The rate constants $V_{0}$ and $k$ were estimated by a 
simultaneous least squares fit of eq 3 to the experimental data, with an individual parameter $k$ for the uninhibited and the inhibited $F X$ activation and a shared parameter $V_{0}$ for the initial rate of FXa generation.

\section{Results}

Initial Rate of FX Activation at the Surface of a Rotating Disc with TF Embedded in a Phospholipid Bilayer. Typical results of FX activation experiments using a rotating disc are shown in Fig. 1. The disc with TF embedded in a planar phospholipid bilayer composed of PSPC or PC was incubated first with FVlla ( $1 \mathrm{nM}$ ) during 5 min before FX (100 nM) was added to start the reaction. Apparently, for both TF:PC and TF:PSPC the FXa activity increases linearly as a function of time. However, the inset to Fig. 1 reveals that, in contrast to the TF:PC surface, it takes for the TF:PSPC surface about $1 \mathrm{~min}$ before $\mathrm{FXa}$ activity starts to increase linearly. This delayed rise in solution FXa activity most likely reflects binding of FXa to the TF:PSPC surface (35). Therefore, the initial rate of $F X$ activation is defined as the linear increase in solution phase FXa 1.5 min after the start of the reaction. When the rotation of the disc was stopped FXa generation halted indicating that under the conditions of the experiment convective transport is essential both for delivery of FX to the catalytic surface and for the transfer of FXa from the surface to the solution. No FXa was produced in the absence of TF or FVIla.

The mean value \pm SD of the initial rate of FXa generation at TF:PSPC after repeated regeneration ( $n=5$ ) of the same disc (see Materials and Methods) was 2.99 $\pm 0.12 \mathrm{nM} \mathrm{min}^{-11}$. For TF embedded in $P C$ the initial rate of $F X a$ generation was 0.82 $\pm 0.07 \mathrm{nM} \mathrm{min}^{-1}$ (mean value $\pm \mathrm{SD}, \mathrm{n}=5$ ). A single TF:PSPC or TF:PC disc could thus be regenerated and used several times allowing repeating experiments under different conditions with an unchanged catalytic active surface. The inter-disc variations were larger with mean values for the initial rate of $F X$ activation $\pm S D$ of $3.24 \pm 0.70 \mathrm{nM} \mathrm{m^{-3 }}(\mathrm{n}=30)$ and $0.77 \pm 0.37 \mathrm{nM} \mathrm{min}^{-1}(n=30)$ for TF:PSPC and $T F: P C$, respectively. It should be noted that the TF:PC membrane preparation contained 5-fold more TF than the TF:PSPC membrane.

Dependency of the Rate of FX Activation on the Angular Velocity of the Rotating DisC. Fig. 2 shows the relation between angular velocity of the rotating disc and the initial rate of FXa formation. For a rotating disc with TF:PSPC the initial rate of FXa formation increases when the angular velocity increases from 0 to $60 \mathrm{rads}^{-1}$. A further increase of the angular velocity does not result in a concomitant increase of the initial rate. Thus an angular velocity of more than 60 rad $s^{-1}$ appears to be sufficient to approach a kinetically controlied situation. That is, the rate at which $F X$ 


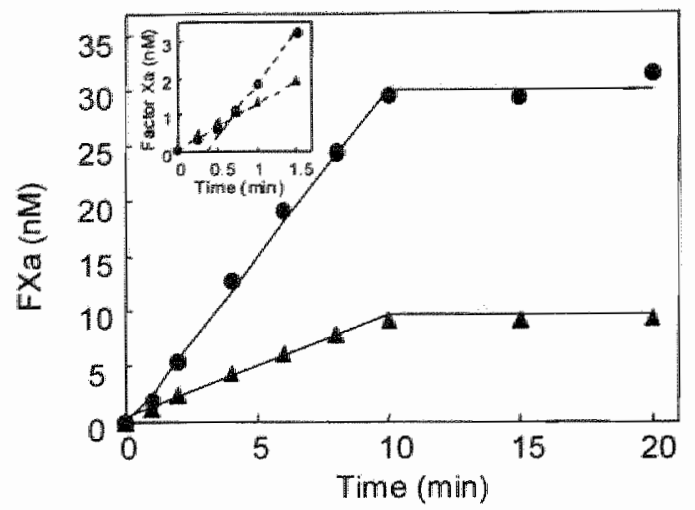

Figure 1. FX activation by TF:phospholipid:FVlla immobilized at the surface of a rotating disc. The TF:PSPC $\left(-2.5 \mathrm{fmol}\right.$ TF $\left.\mathrm{cm}^{-2}\right)$ or TF:PC $\left(\boldsymbol{\Lambda}, 12.5 \mathrm{fmol}\right.$ TF $\left.\mathrm{cm}^{-2}\right)$ surface was incubated with FVllla (1 $\mathrm{nM}$ ) for $5 \mathrm{~min}$ in $\mathrm{TBSA}_{-} \mathrm{CaCl}_{2}$ buffer and the reaction was started by adding $\mathrm{FX}(100 \mathrm{mM})$. Samples were taken at the indicated time points and assayed for FXa. At $t=10 \mathrm{~min}$ the rotation $\left(63 \mathrm{rad} \mathrm{s}^{-1}\right)$ was stopped whereas sampling was continued. The initial rate $\left(V_{0}\right)$ of $F X$ activation, derived from the increase in FXa concentration measured between 2 and $8 \mathrm{~min}$, is $3.15 \mathrm{nM} \mathrm{min}^{-1}$ for TF:PSPC and $0.85 \mathrm{nM}$ $\min ^{-1}$ for TF:PC. Inset: FXa generation during the initial phase of the reaction.

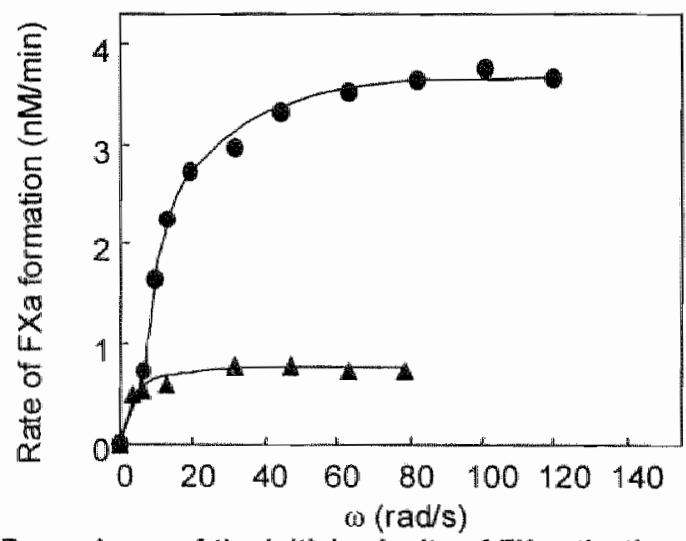

Figure 2. Dependency of the initial velocity of $\mathrm{FX}$ activation on the angular velocity of the rotating discs. At the indicated angular velocities, the initial rate of $\mathrm{FX}$ activation was measured on TF:PSPC (C) and TF:PC (A) as described in the legend to Fig.1. A single rotating disc was used that was regenerated for each measurement by flushing (10 $\mathrm{mL} \mathrm{min}^{-1}$ ) the reaction vessel and spinning disc for $5 \mathrm{~min}$ with TBSA-EDTA and subsequently for $5 \mathrm{~min}$ with TBSA-CaCl 2 buffer. 
is activated at the surface is smaller than the transport limited rate of FX delivery to the catalytic surface. A similar experiment was also performed with TF embedded in PC (Fig. 2). Obviously, an apparent kinetically controlled FX activation is achieved at a lower angular velocity $\left(30 \mathrm{rad} \mathrm{s}^{-1}\right)$ than observed with TF:PSPC. The 5-fold lower rate of FX activation at the TF:PC surface likely reduces the transport-limited supply of reactants. All further experiments were performed at an angular velocity of $63 \mathrm{rad}$ $\mathrm{s}^{-1}$.

Kinetic Parameters for FX. Activation at the Rotating Disc. Based on a previously reported $K_{d}$ value of $41 \mathrm{pM}$ for FVlla binding to TF in PSPC vesicles (36), we reckoned that a FVlla concentration of $1 \mathrm{nM}$, as used in the experiments described above, was sufficient to saturate all the TF exposed at the catalytic surface. To verify whether this assumption applied for the rotating disc system we measured the initial rate of FX activation as a function of the solution phase FVlla concentration. The titration curves obtained (data not shown) were analyzed using Equation 1 to yield binding as well as kinetic parameters. For TF:PSPC the fit yielded a $K_{d}$ of $18 \mathrm{pM}$ and for TF:PC the $K_{d}$ value was $240 \mathrm{pM}$. Thus whereas the $K_{d}$ of FVlla for TF:PSPC is in good agreement with the value previously reported $(36,37)$, the affinity of FVlla for $T F: P C$ is 10 -fold higher than values reported by others $(32,36)$. Hence a FVlla concentration of $1 \mathrm{nM}$ is indeed sufficient to saturate more than $80 \%$ of the TF present at the PC and PSPC surfaces. Furthermore, the fit yielded a $V_{\max }$ of $4.4 \mathrm{nM}$

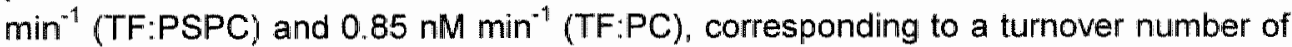
$1677 \mathrm{~min}^{-1}$ for TF:PSPC and of $65 \mathrm{~min}^{-1}$ for TF:PC.

Likewise, the relationship between the initial rate of $\mathrm{FX}$ activation at the spinning surface and the fluid-phase FX concentration was determined for TF:PSPC and TF:PC. By fitting Equation 2 to the experimental data (not shown) we estimated values of $110 \mathrm{nM}$ for the apparent $K_{m}\left(K_{m, a p p}\right)$ and of $5.5 n M m^{-1}$ for $V_{\max }$. Calculation on basis of an estimated TF density of the PSPC surface $\left.(2.5 \mathrm{fmol} \mathrm{cm})^{-2}\right)$ gave a $k_{\text {cat }}$ value of $2098 \mathrm{~min}^{-1}$ for TF:PSPC. For TF:PC a linear relation between the FXa generation rate and the FX concentration was found in spite of a much higher (up to $400 \mathrm{nM}$ ) FX concentration employed (data not shown). This indicated for the TF:PC a $K_{m, a p p}$ value of $>5 \mu \mathrm{M}$, thus at least one order of magnitude greater than the highest $\mathrm{FX}$ concentration used.

Inhibition of Membrane-Associated TF:FVIIa as a Function of the Concentration of FXa:TFPI. In a successive set of experiments we assessed the inhibitory activity of preformed $F X a: T F P I_{F L}$ and $F X a: T F P I_{1-161}$ complexes towards TF:FVlla-catalyzed FX activation at TF:PC and TF:PSPC membranes deposited on rotating discs. Following a pre-incubation with FVlla for 5 min, the reaction was started by the simultaneous addition of FX (100 nM) and inhibitor complexes in varying concentrations. All inhibition experiments were preceded by a control experiment in the absence of inhibitor to assess the precise catalytic activity of that particular rotating disc. To correct for inter-disc variations in catalytic activity ( $\pm 20 \%$, as shown before), the $\mathrm{FXa}$ 
generated in the presence of inhibitor is expressed as a percentage of the corresponding amount of $F$ Xa generated after 10 min in the absence of inhibitor.

It is seen from Fig. 3A that the rate of FXa generation on TF:FVlla:PC in the presence of FXa:TFPI 1 -161 gradually decreases in time and that this progressive inhibition becomes more pronounced at higher inhibitor concentrations. The very same observations were made with FXa:TFPl $\mathrm{FL}$ as inhibitor (Fig. 3B). The FXa generation curves were analyzed according to a model that assumes that complex formation between TF:FVIIa and FXa:TFPI results in a quaternary complex in which the catalytic activity of TF:FVlla is completely blocked (eq 3, Materials and Methods). The hypothesis that the initial FXa generation rate did not alter by addition of the FXa:TFPI complex was checked by fitting eq 3 to the individual curves of the pairs of uninhibited and inhibited FXa generation. The value obtained for $V_{0}$ of the inhibited curve, expressed as percentage of $V_{0}$ of the uninhibited curve was $96 \pm 6 \%$ and 105 $\pm 9 \%$ (mean \pm S.D.; $n=6$ ) for $\mathrm{FXa}_{\mathrm{T}} \mathrm{TFPl}_{\hat{1-161}}$ and $\mathrm{FXa}$.TFPl FL complexes respectively. These data thus justify our analysis of the FXa generation curves by a simultaneous fit of eq 3 to the uninhibited and inhibited curves with a shared rate constant $V_{0}$. The solid lines in Fig. 3A-B show the result of this fitting procedure which yielded pseudofirst order rate constants of inhibition $(K)$ as a function of the concentration of the inhibitory complex (Fig. 3C). It is clear that $\mathrm{k}$ increases linearly with the concentration of the inhibitory complex. This indicates that, in the concentration range employed, the bimolecular association of TF:FVIla with preformed FXa:TFPI is the rate-limiting step of the formation of the quaternary TF:FVIla:FXa:TFPI complex. The second order rate constants of inhibition (Table 1) as were obtained by linear regression to

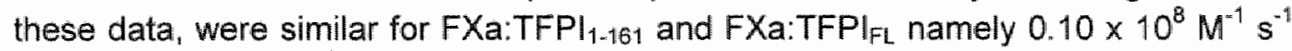
and $0.07 \times 10^{8} \mathrm{M}^{-1} \mathrm{~s}^{\mathrm{m} !}$.

The same experiments were performed with TF embedded in PSPC. Comparison of Fig. 4A and Fig. 3A shows that FXa:TFPl/16 inhibits TF:FVlla more efficiently at a PSPC surface than at a PC surface. A solution phase concentration of $0.4 \mathrm{nM}$ FXa:TFPl 1-161 $_{1}$ is sufficient to neutralize TF:FVIla activity almost instantaneously. In contrast, with the same concentration of FXa:TFPIFL complex at TF:PSPC (Fig. 4B), a significant FXa generation is still observed. The FXa generation curves as shown in Fig. 4 were analyzed as described for those in Fig. 3. The pseudo-first order rate constants of inhibition thus obtained are presented in Fig. $4 \mathrm{C}$ as a function of the concentration of the inhibitory complex. This plot clearly reveals the difference in inhibitory activity of $\mathrm{FXa}_{\mathrm{A}} \mathrm{TFPl}_{1-164}$ and $F \mathrm{Xa}$ :TFPlFL on TF:PSPC. According to Table 1, the second order rate constant of inhibition for FXa:TFPl ${ }_{1-161}$ and FXa:TFPlFL increases when PS is present in the TF bearing membrane. However, the increase for FXa:TFPI ${ }_{1-161}$ is about 9 -fold whereas a 3 -fold increase is seen for FXa:TFPl FL. The rate constant of $0.94 \times 10^{8} \mathrm{M}^{-1} \mathrm{~s}^{-1}$ found for 

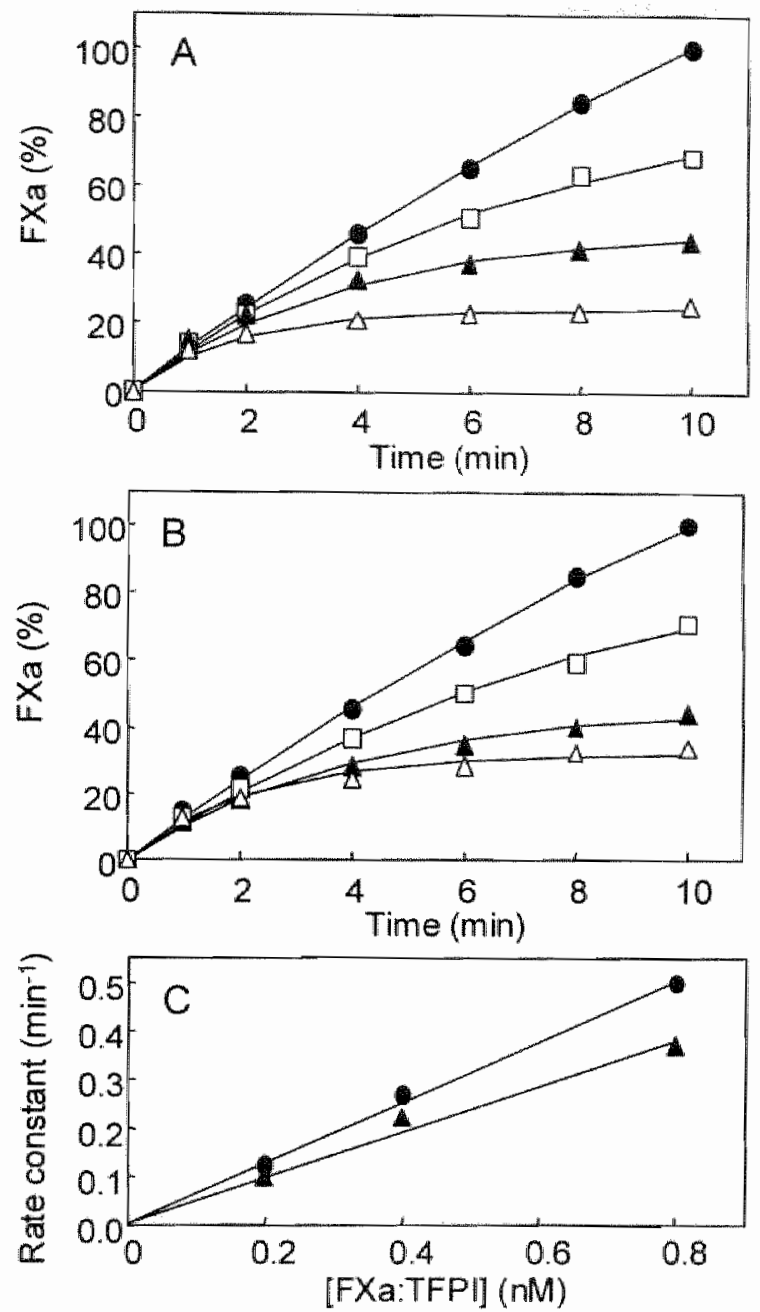

Figure 3. Inhibitory activity of FXa:TFPI towards TF:FVlia:PC. The TF:PC surface was incubated with FVlla ( $1 \mathrm{nM}$ ) for $5 \mathrm{~min}$. Subsequently the reaction was started by adding

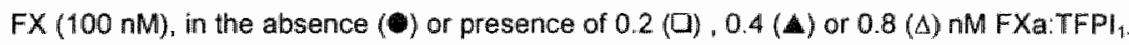
ifi (panel A) or FXa:TFPlFL. (panel B). Samples were taken at the indicated time points and assayed for FXa activity which is expressed as a percentage of the amount of FXa formed after $10 \mathrm{~min}$ in the absence of inhibitor. The solid lines are drawn according to the best fit of eq 3 to the experimental data. In Panel $C$ the rate constants obtained by the fit

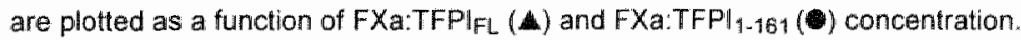


FXa.TFPly is is in good agreement with the previous reported value of $1.1 \times 10^{8} \mathrm{M}^{-1}$ $s^{-1}(23)$ whereas the value for FXa:TFPl $\mathrm{FL}\left(0.20 \times 10^{8} \mathrm{M}^{-1} \mathrm{~s}^{-1}\right)$ is $5-10$ fold lower than the values reported previously $(22,23)$. Thus at TF:PSPC, FXa:TFPIFL apparently has a lower inhibitory activity than FXa:TFPli-16.1. In view of our earlier finding that FXa:TFPlFi. complexes have a considerably higher affinity for PS containing lipid membranes than complexes of $\mathrm{FXa}_{\mathrm{TFPI}} \mathrm{TH}_{161}$, these data suggest that upon binding to TF:PSPC, FXa:TFPI $F$ complexes lost their inhibitory action.

Table 1 second order rate constant of inhibition of TF:FVlla as determined from inhibition of TF:FVIlla mediated FX activation at the phospholipid surface of a rotating disc.

\begin{tabular}{|c|c|c|}
\hline \multirow[t]{2}{*}{ Innibitor } & \multicolumn{2}{|c|}{ Rate constant of inhibition } \\
\hline & $T F: P C$ & TF:PSPC \\
\hline & $M^{11} s^{-1}$ & $M^{-1} s^{-1}$ \\
\hline FXa:TFPl ${ }_{1-161}$ & $0.10 \pm 0.01 \times 10^{8}$ & $0.94 \pm 0.05 \times 10^{8}$ \\
\hline FXa:TFP $\|_{F L}$ & $0.07 \pm 0.02 \times 10^{8}$ & $0.20 \pm 0.02 \times 10^{8}$ \\
\hline
\end{tabular}

Inhibition of TF:FVIT-Catalyzed FX Activation by Membrane-Bound FXa:TFPI Complex. FXa:TFPI $\mathrm{FL}_{\text {and }}$ FXa:TFPl ${ }_{1-161}$ complexes $(0.4 \mathrm{nM})$ were incubated for 10 min with TF.PSPC coated discs spinning at $63 \mathrm{rad} \mathrm{s}^{-1}$. In some cases FXa:TFPI complexes were, after the incubation, removed from the solution by flushing the reaction vessel with a TBSA-CaCl 2 buffer during $5 \mathrm{~min}$ at $10 \mathrm{~mL} \mathrm{~min}^{-1}$. FXa generation was initiated by the simultaneous addition of FX (100 nM) and FVlla (1 nM). Fig. 5A shows the time courses of FXa generation for TF:PSPC surfaces that were pre-incubated with $\mathrm{FXa}_{\mathrm{TFPl}} \mathrm{TH}_{161}$ with inhibitor complexes remaining in solution during the FXa generation and with inhibitor complexes removed from solution at the end of the pre-incubation. For comparison we also show the FXa generation in the absence of inhibitory complexes and the FXa generation as observed when the inhibitory complexes were added simultaneously with FX. It is apparent from Fig. 5A that as long as the FXa:TFPI ${ }_{161}$ is not depleted from the solution, identical inhibition is seen with or without pre-incubation whereas depletion of the inhibitory complex from the solution completely removes the inhibitory activity. 

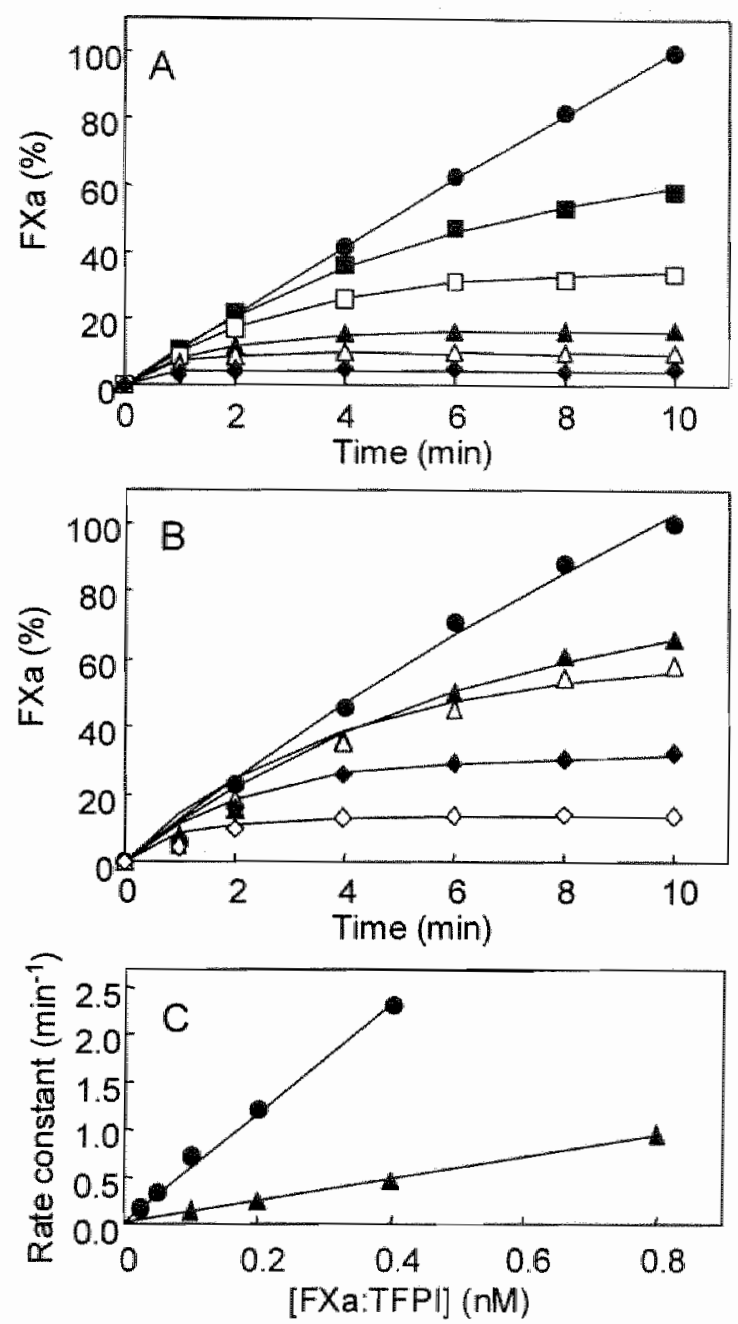

Figure 4. Inhibitory activity of FXa:TFPI towards TF:FVIla:PSPC. The experiment was performed essentially as described in the legend to Fig. 3 but now with a TF:PSPC

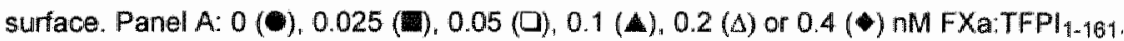
Panel B: $0(0), 0.1(\Delta), 0.2(\Delta), 0.4(\$)$ or $0.8(0) \mathrm{nM}$ FXa:TFPIFL. The solid lines are drawn according to the best fit of eq 3 to the FXa generation curves. In Panel $\mathrm{C}$ the rate constants thus abtained are plotted as a function of FXa:TFPI FE. $_{\text {(4) }}$, and FXa:TFPI $4-161$ (C) concentration. 
Similar experiments performed with $F X a: T F P I_{F L}$ complexes gave a completely different outcome, as shown in Fig. 5B. The largest extent of inhibition of FXa generation is observed when the TF:PSPC membrane was pre-incubated with FXa:TFPlFL complexes. But even more striking, it turned out that depletion of the solution from FXa:TFPlFL complex by flushing the reaction vessel at the end of the pre-incubation did not diminish the inhibitory activity. This indicates that under the conditions of this experiment, the contribution of TF:PSPC bound FXa:TFPIFL complexes to the inhibitory activity is dominant. To ascertain that the inhibitory activity that remained manifest after flushing originated from $F X a: T F P I_{F L}$ bound to the TF:PSPC surface and not from inhibitory complex non-specifically bound to the wall of the reaction vessel, we performed the following control experiment. The reaction vessel was pre-incubated for $10 \mathrm{~min}$ with $0.4 \mathrm{nM}$ FXa:TFPlFL and flushed for 5 min with TBSA-CaCl 2 buffer, after which an unused TF:PSPC coated disc was placed in the vessel. Subsequently the rate of FXa formation at that disc was measured following the addition of FVIIa $(1 \mathrm{nM})$ and FX (100 nM). No inhibition was observed, showing that the retained inhibitory activity in the previous experiment solely originated from TF:PSPC-bound FXa:TFPI FL complexes.

The different effects of flushing on the inhibitory activity (Fig. 5A-B) of the FXa:TFP $\|_{1-161}$ and FXa:TFPl $\left.\right|_{F L}$ complexes at TF:PSPC presumably reflect the differences in desorption rates of these complexes that were previously reported (24). As has been shown, at a macroscopic PSPC surface (no TF present) the residence time of membrane bound FXa:TFPIFL was about 45 min, compared to a

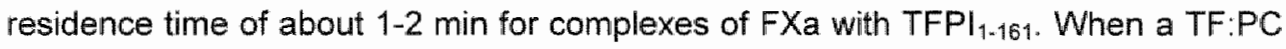
surface was preincubated with FXa:TFPI $F L(0.4 \mathrm{nM})$ and subsequently washed for 5 min as described above, an uninhibited FXa generation was observed (data not shown). Thus omitting the negatively charged phospholipids from the membrane resulted in loss of FXa:TFPIFL membrane binding and thus of the exerted inhibitory activity. Additional support was obtained when, following the pre-incubation of the TF:PSPC surface with FXa:TFPIFL, the time-period of flushing with buffer was increased (from 5 to $90 \mathrm{~min}$ ). This resulted in a gradually decreasing inhibitory activity (Fig. 6). Noteworthy though, even after a rinse for 90 min still a significant inhibition of FXa generation is observed.

Further analysis of inhibited and uninhibited FXa generation curves as presented in Fig. 5B and Fig. 6, reveals that pre-incubation of TF-PSPC with FXa:TFPIFL results in a major decrease of the initial rate of $F X$ activation. Correspondingly, the simultaneous fit of eq 3 to the inhibited and the matching uninhibited FXa generation curves with a shared rate constant $V_{0}$, as used in the fits of Fig. 3-4, resulted in an inadequate fit with large systematic deviations. Using individualized parameter values of $V_{0}$, however, resulted in excellent fits (solid lines Fig. $5 \mathrm{~B}$ and Fig. 6). The estimated parameters $V_{0}$ and $k$, listed in Table 2, show that 

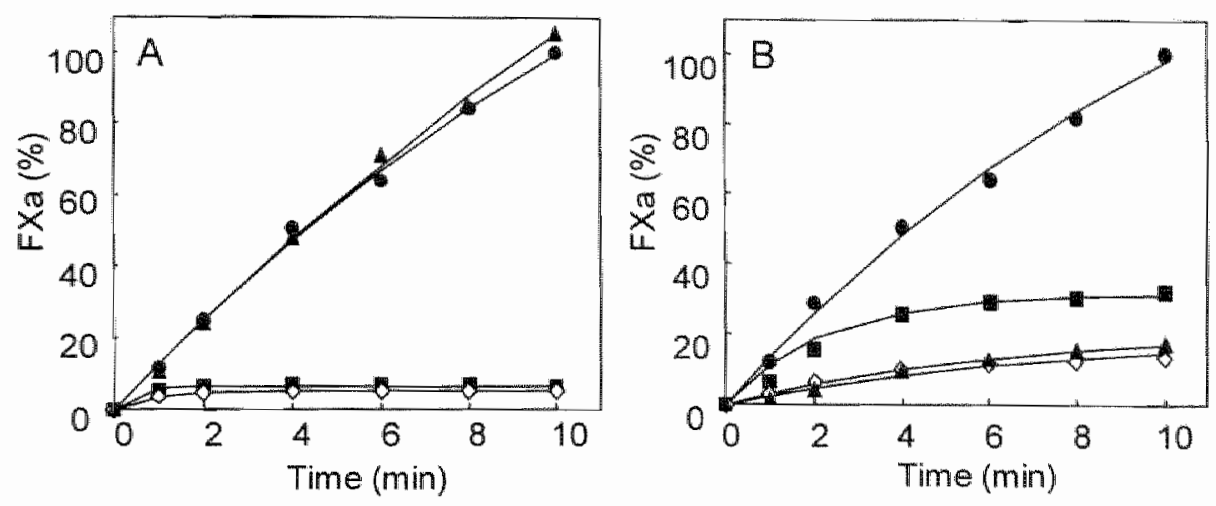

Figure 5. Retention of TF:PSPC membrane-bound inhibitory activity. The TF:PSPC disc surface was pre-incubated for 10 min with $0.4 \mathrm{nM} \mathrm{FXa:TFP/1-161} \mathrm{(panel} \mathrm{A)} \mathrm{and} 0.4$ nM FXa:TFPl $\|_{F L}$ (panel $B$ ). Then the reaction vessel and rotating disc were either not flushed $(\Leftrightarrow)$ or flushed $\left(10 \mathrm{~mL} \mathrm{~min}^{-1}\right)$ for 5 min with TBSA-CaCl 2 buffer (A). FX activation was started by addition of FVlla ( $1 \mathrm{nM})$ and FX (100 $\mathrm{mM})$. For comparison data from Fig. 4 are shown: FX activation in the absence of inhibitor ( ) and the inhibition of FX generation when the inhibitory complex is added simultaneously with FX (1). Solid lines indicate the best fit of eq 3 to the individual curves. The FXa activity is presented as a percentage of the amount of FXa formed $10 \mathrm{~min}$ after the start of the reaction in the absence of inhibitor.

the initial rate of FXa generation of the pre-incubated curves is instantaneously decreased to about $25 \%$ of the uninhibited $V_{0}$ when FXa generation is initiated shortly $(0-5 \mathrm{~min})$ after the pre-incubation. With increasing flushing time, a gradual increase of the estimated $V_{0}$ is observed, from $27 \%$ after 5 min flushing to $59 \%$ after 90 min flushing. The rate constants found for the exponential decay of the TF:FVlla activity ranged from 0.08 to $0.15 \mathrm{~min}^{-1}$, dependent on the flushing time. These values are 3- to 5-fold lower than the decay rate of $0.42 \mathrm{~min}^{-1}$, found for the inhibition of TF:FVIla when the same concentration of FXa:TFPIFL was added to the reaction mixture (Fig. 4). 


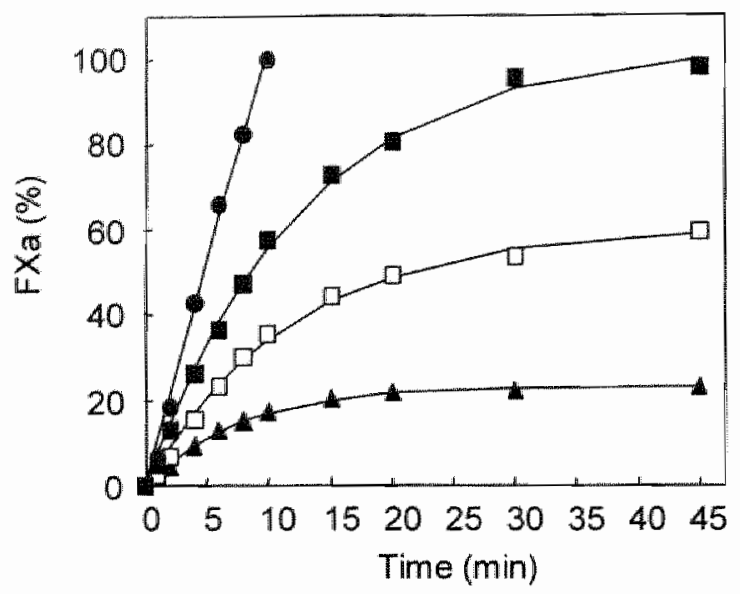

Figure 6. Time-dependent decrease of the inhibitory activity of FXa:TFPI FL $_{\text {L }}$ complexes pre-adsorbed on TF:PSPC. The TF:PSPC disc surface was pre-incubated for 10 min with FXa:TFPlFL $(0.4 \mathrm{nM})$. Then the reaction vessel and rotating disc were flushed for 5 (4), $45(0)$ or 90 (D) min with TBSA-CaCl 2 buffer $\left(10 \mathrm{~mL} \mathrm{~min}^{-1}\right)$. FX activation was started by addition of FVIla ( $1 \mathrm{nM})$ and FX (100 $\mathrm{nM}$ ). FXa generation in the absence of inhibitor is indicated by the closed circles. Solid lines indicate the best fit of eq 3 to the individual curves. The FXa activity is presented as a percentage of the amount of FXa formed after 10 min in the absence of inhibitor.

Table 2 Fit parameters $k$ and $V_{a_{1}}$ see eq 3 , as determined from TF:FVlla mediated FX activation initiated by simultaneous addition of FVlla and FX after pre-incubation of the TF:PSPC surface during 10 min with FXa:TFPIFL complexes $(0.4 \mathrm{nM})$ followed by no flushing or a flush of the reaction vessel with $\mathrm{Ca}^{2+}$ containing buffer $\left(10 \mathrm{~mL} \mathrm{~min}^{-1}\right)$ during the indicated period. $V_{0}$ is presented as percentage of the initial rate of FXa generation of the paired uninhibited curve obtained at the same disc.

\begin{tabular}{lll}
\hline Flushing time & $\mathrm{V}_{0}$ & $\mathrm{k}$ \\
\hline min & $\%$ & $\mathrm{~min}^{-1}$ \\
& & \\
No Flush & 26 & 0.15 \\
5 & 27 & 0.13 \\
45 & 44 & 0.08 \\
90 & 59 & 0.08 \\
\hline
\end{tabular}




\section{Discussion}

Rationale Behind Experimental Design. In this study we addressed the question whether the previously reported (24) high affinity of FXa:TFPlFL for negatively charged phospholipids is reflected in its inhibitory activity against TF:FVIlla. Because phospholipids were also shown to enhance complex formation between FXa and TFPI $(16,23)$ preformed FXa:TFPl and FXa:TFPl 1-161 $_{1-1}$ complexes were used in this study to simplify the interpretation of the experimental data on the effect of phospholipids on the TF:FVIIa inhibition by FXa:TFPI. Furthermore a macroscopic phospholipid membrane (with embedded TF) was used rather than unilamellar vesicles because this model mimics the plasma membrane of TF-bearing cells better than small unilamellar vesicles. Moreover, several studies have shown that the kinetics of activation and inactivation of blood coagulation enzyme complexes are dependent on the characteristics of the phospholipid surface like the radius of the phospholipid vesicle $(35,38)$, microscopic homogeneity $(39)$ and ratio of reactantbearing vesicles over non-bearing vesicles (25). Additionally, with macroscopic surfaces it is easier to separate physically the surface-bound and fluid-phase reactions. The use of a macroscopic phospholipid membrane at the surface of a rotating disc (40) has been extensively characterized for immobilized enzymes (33, 41,42 ). Its main advantage over flow systems like that of a capillary flow reactor ( 43 , $44)$ is the uniformly accessibility of the surface (40).

Determination of the Kinetics of FX Activation Using the Rotating Disc System. Our study confirms the role of anionic phospholipids in the binding of FVIla to TF embedded in a phospholipid bilayer: the $K_{d}$ of FVlla for TF:PC (240 pM) is 13-fold higher than the $K_{d}$ of FVlla for TF:PSPC (18 pM).

The $K_{\text {cat }}\left(35 \mathrm{~s}^{-1}\right)$ and $K_{m, a p p}(110 \mathrm{nM})$ values for TF:FVIla catalyzed FX activation at PSPC are in reasonable agreement with the $k_{c a t}=12 \mathrm{~s}^{-1}$ and $K_{m}=70 \mathrm{nM}$ measured at TF-bearing PSPC vesicles $(23,45)$. Though, others have reported much higher values (46). A trivial explanation for this apparent discrepancy could be the high vesicle concentration in the latter study. The estimated occupancy of the TF:FVIla by FX, as determined from $K_{m}$ values in PSPC and PC is $47 \%$ and less than $2 \%$ respectively, suggesting that some competition between substrate and inhibitor for TF:FVlla might be expected at PSPC but not at PC.

Inhibition Kinetics of TF:FVIIa-Catalyzed FX Activation as Studied at a Rotating Disc Surface. The similar kinetics of TF:FVIla inhibition that were observed for FXa:TFPl $F$ and FXa:TFPI $\left.\right|_{1-161}$ on a TF:PC surface, which does not bind FXa (47) nor TFPI $_{F L}(48)$, are consistent with other studies which indicated that a direct interaction of FXa:TFPI with TF:FVIla does not require the binding of FXa:TFP $\|$ to negatively charged phospholipids $(22,43,49)$. Kazama (50), however, concluded from studies using TF lacking the trans-membrane and cytoplasmic domains that binding of FXa 
to anionic phospholipids via its Gla-domain may be an absolute requirement for TFPI mediated regulation of full length membrane-inserted TF.

Interestingly, the addition of PS $(25 \%)$ to a neutral membrane brings about a significant stimulation of the rate of inhibition by both FXa:TFPI $\mathrm{FL}\left(\mathrm{k}=0.20 \times 10^{8} \mathrm{M}^{-1}\right.$ $\left.\mathrm{s}^{-1}\right)$ and $F X_{a}: \operatorname{TFP}_{1-161}\left(\mathrm{~K}=0.94 \times 10^{8} \mathrm{M}^{-1} \mathrm{~s}^{-1}\right)$. We note that the marked difference in fractional saturation of TF:FVIla on a PC membrane and that of TF:FVIla on a PSPC membrane as aforementioned could mask the stimulatory effect of PS. When FX and FXa:TFPI compete for TF:FVIla at PSPC than it can be calculated according to the relation $k^{\text {true }}=k^{\text {obs }}\left(1+S / K_{m}\right)$ that the true rate constants of inhibition (FXa:TFP). 161: $1.79 \times 10^{8} \mathrm{M}^{-1} \mathrm{~s}^{-1}$, FXa:TFPlFL: $0.38 \times 10^{8} \mathrm{M}^{-1} \mathrm{~s}^{-1}$ ) are about 2-fold higher then the observed rate constants (Table 1). Because for TF:PC the $K_{m}$ is much larger than the substrate concentration $[F X]$, competition is in this case negligible. As a result, the differences in rate constants of inhibition at a membrane with PSPC and pure PC become even more pronounced.

The stimulatory effect of PS on the inhibition of both FXa:TFPl ${ }_{1-151}$ and FXa:TFPl FL, might be related to the FXa mediated binding of the complexes to the phospholipid membrane (24). Several mechanisms have been proposed to explain the membrane-mediated acceleration of reactions of the blood coagulation system. Next to a proper juxtaposition of the FXa:TFPI complexes towards the active site of the FVIla, anionic planar phospholipid membranes may also allow lateral diffusion of the substrate towards the membrane associated enzymatic complex as shown in experiments on prothrombin activation $(33,34,38)$. As a result a much lower solution phase substrate concentration is needed to saturate half of the immobilized enzyme. If this mechanism would be operational for the inhibition of TF embedded in the PSPC membrane one would predict the highest rate constant of inhibition for the inhibitory complex with the highest affinity for the membrane. Our experiments; however, show the opposite; the presence of PS stimulated FXa:TFPI $\left.\right|_{1-161}$ 9-fold compared to the only 3-fold stimulation of FXa:TFPIFl. Apparently the high affinity binding of FXa:TFPlFL with PSPC membranes is accompanied by a lower inhibitory activity. These data thus suggest that solution phase and membrane bound FXa:TFPIFt contribute to the overall inhibition reaction but to a different extent. Therefore the description of the inhibition reaction by a bimolecular association reaction (eq 3), although it adequately describes the experiment of Fig. 3-4, presents a gross simplification. Indeed, the experiments in Fig. 5-6 demonstrate that inhibition of TF:FVlla at PSPC by pre-adsorbed FXa:TFPl $\mathrm{FL}$ is in fact a multi-step process. After a rapid inactivation of $\pm 75 \%$ of the TF:FVlla activity, as suggested by the reduced initial rate of FXa generation after the addition of FVIla and FX, a much slower elimination of the remaining activity is observed. This rapid first phase suggests that the membrane bound pool of FXa:TFPIFL may, also in the absence of FVIla, associate with TF (5i) and that this ternary complex upon addition of FVlla and $F X$ rapidly converts to the quaternary complex. Alternatively, FXa:TFPI $F_{L L}$ binding 
to TF could interfere with the interaction of TF with FVIla. However, the same study on TF:PC showed no persistent inhibitory activity. This indicates that the high affinity binding of FXa:TFPl FL to TF:PSPC membranes is the result of a protein (FXa:TFPI)lipid interaction rather than a protein (FXa:TFPl)-protein (TF) interaction. The decreasing extent of the initial inhibition with increasing flushing time as shown in Table 2, thus probably reflects the decrease of the membrane bound pool of FXa:TFPI $\|_{F L}$.

Taken together, our data indicate efficient inhibition both by fluid phase FXa:TFPI FL and by phospholipid-bound complex. The complex between full length TFPI and FXa is so tightly bound to the catalytic TF:PSPC surface that it represents a highly effective pool of inhibitory activity that remains available for hours after exposure of the membrane to FXa:TFPlFL complexes. This property may be of physiological importance in allowing an on-site regulation of the TF:FVIla activity. That is, this phospholipid-bound pool of inhibitor complex, which is immediately available, may represent an effective control of newly formed catalytic units when newly synthesized TF arrives at the plasma membrane of TF producing cells.

\section{References}

1. Nemerson $Y(1988)$ Tissue factor and haemostasis. Blood $71,1-8$.

2. Rapaport SI and Rao LVM (1995) The tissue factor pathway: How it has become a "prima ballerina". Thromb Haemost $74,7-17$.

3. Davie EW, Fujikawa K and Kisiel W (1991) The coagulation cascade: Initiation, maintenance, andi regulation. Biochemistry 30, 10363-70.

4. Drake TA, Morrissey JH and Edgington TS (1989) Selective cellular expression of tissue factor in human tissues. Am J Pathol 134, 1087-97.

5. Fleck RA, Rao LVM, Rapaport SI and Varki N (1990) Localization of human tissule factor antigen by immunostaining with monospecific, polyclonal anti-human tissue factor antibody. Thromb Res $59,421-37$.

6. Broze GJ Jr, Girard TJ and Novolny WF (1990) Regulation of coagulation by a multivalent Kunitztype inhibitor. Blochemistry $29,7539-46$.

7. Rapaport SI (1991) The extrinsic pathway inhibitor: A regulator of tissue factor-dependent blood coagulation. Thromb Haemost 66, 6-15.

8. Wun TC, Kretzmer KK, Girard TJ, Miletich JP and Broze GJ Jr (1988) Cloning and characterization of a CDNA coding for the lipoprotein-associated coagulation inhibitor shows that it consists of three tandem Kunitz-type inhibitory domains. I Biol Chem 263, 6001-4.

9. Girard TJ, Warren LA, Novotny WF, Likert KM, Brown SG, Miletich JP and Broze GJ Jr (1989) Functional significance of the Kunitz-type inhibitory domains of lipoprotein associated coagulation inhibitor. Nature 338, 518-20. 
10. Petersen LC, Bjön SE, Olsen OH, Nordfang O. Norris F and Norris K (1996) Inhibitory properties of separate recombinant Kunitz-type-protease-inhibitor domains from tissue factor pathway inhibitor. Eur ل Bioch $235,310-6$.

11. Valentin $S$, Nordiang $O$, Bregengard $C$ and Wildgoose $P$ (1993) Evidence that the $C$-terminus of tissue factor pathway inhibitor (TFPI) is essential for its in vitro and in vivo interaction with lipoproteins. Blood Coag Fibrinoll 4, 743-20.

12. Enjyoji K Miyata T, Kamikubo $Y$ and Kato $H$ (1995) Effect of heparin on the inhibition of factor Xa by tissue factor pathway inhibitor: a segment, Gly212-Phe243, of the third Kunitz domain is a heparin-binding site. Biochemistry $34,5725-35$.

13. Nordfang $O$, Björn SE, Valentin S, Nielsen LS, Vildgoose $P$. Beck TC and Hedner U (1991) The C-terminus of tissue factor pathway inhibitor is essential to its anticoagulant activity. Biochemistry $30,10371-6$.

14. Wesselschmidt R, Likert K, Girard T, Wun TC and Broze GJ Jr (1992) Tissue factor pathway inhibitor: The carboxy-terminus is required for optimal inhibition of factor $\mathrm{Xa}$. Blood 79, 2004-10.

15. Hamamoto $T$, Yamamoto $M$, Nordfang $O$, Petersen JG, Foster DC and Kisiel $W(1993)$ Inhibitory properties of full-length and truncated recombinant tissue factor pathway inhibitor (TFPl). Evidence that the third Kunitz-type domain of TFPI is not essential for the inhibition of factor V/latissue factor complexes on cell surfaces. J Biol Chem 268, 8704-10.

16. Huang ZF, Wun TC and Broze GJ Jr (1993) Kinetics of Factor-Xa inhibition by tissue factor pathway inhibitor. J Biol Chem 268, 26950-5.

17. Jesty $J$, Wun TC and Lorenz A (1994) Kinetics of the inhibition of factor Xa and the tissue factorfactor Vila complex by the tissue factor pathway inhibitor in the presence and absence of heparin. Biachemistry $33,12686-94$.

18. Lindhout T, Willems GM, Blezer R and Hemker HC (1994) Kinetics of the inhibition of human factor Xa by full-length and truncated recombinant tissue factor pathway inhibitor. Biochem J 297 , $131-6$.

19. Salemink I. Franssen J, Willems GM, Hemker HC, Li A, Wun TC and Lindhout T (1998) Factor Xa cleavage of tissue factor pathway inhibitor is associated with loss of anticoagulant activity. Thromb Haemost $80,273-80$.

20. Broze GJ Jr, Warren LA, Novotny WF, Higuchi DA, Girard JJ and Miletich UP (1988) The lipoprotein-associated coagulation inhibitor that inhibits the factor VII-tissue factor complex also inhibits factor $\mathrm{Xa}$ : insight into its possible mechanism of action. Blood 71, 335-43.

21. Callander NS, Rao LVM, Nordfang O, Sandset PM. Warn-Cramer B and Rapaport SI (1992) Mechanisms of binding of recombinant extrinsic pathway inhibitor (rEPl) to cultured cell surfaces. Evidence that rEPI can bind to and inhibit factor Vlla-tissue factor complexes in the absence of factor Xa. J Biol Chem 267, 876-82.

22. Baugh RJ, Broze GJ Jr and Krishnaswamy $S$ (1998) Regulation of extrinsic pathway factor Xa formation by tissue factor pathway inhibitor. J Biol Chem 273, 4378-86.

23. Lindhout T. Franssen $J$ and Willems GM (1995) Kinetics of the inhibition of tissue factor-factor Vila by tissue factor pathway inhibitor. Thromb Haemost $74,910-5$. 
24. Willems GM, Janssen M, Salemink I, Wun TC and Lindhout T (1998) Transient high affinity binding of Tissue Factor Pathway Inhibitor-Factor $\mathrm{Xa}$ complexes to negatively charged phospholipid membranes. Biochemistry 37, 3321-8.

25. Nesheim ME, Tracy RP and Mann KG (1984) "Cloispeed," a mathematical simulation of the functionall properties of prothrombinase. $₫$ Biol Chem $258.1447-53$.

26. van Rijn JL, Govers-Riemslag JW, Zwaal RF and Rosing J (1984) Kinetic studies of prothrombin activation: Effect of factor $V a$ and phospholipids on the formation of the enzyme-substrate complex. Biochemistry 23, 4557-64.

27. Mertens $K$ and Bertina RM (1980) Pathways in the activation of human coagulation factor $X$. Biochem J 185, 647-58.

28. Lindhout MJ, Kop-Klaassen $\mathrm{BH}$ and Hemker $\mathrm{HC}$ (1978). Activation of decarboxyfaction $\mathrm{X}$ by a protein from Russell's viper venom. Purification and partial characterization of activated decarboxyfactor X. Biochim Biophys Acta 533, 327-41.

29. Smith RL (1973) Titration of activated bovine Factor $X$. J Biol Chem 248, 2418-23.

30. Diaz-Collier JA, Palmier MO, Kretzmer KK, Bishop BF, Combs RG, Obukowicz MG, Frazier RB, Bild GS, Joy WD, Hill SR, Duffin KL, Gustafson ME, Junger KD, Grabner RW, Galluppi GR and Wun TC (1994) Refold and characterization of recombinant tissule factor pathway inhibitor expressed in Escherichia cali. Thromb Haemost 71, 339-46.

31. Petersen JG, Meyn G, Rasmussen JS, Petersen J, Björn SE, Jonassen I, Christiansen L and Nordfang $O$ (1993) Characterization of human tissue factor pathway inhibitor variants expressed in Saccharomyces cerevisiae. J Bial Chem 268, 13344-51.

32. Bach $R$, Gentry $R$ and Nemerson $Y$ (1986) Factor $V / \|$ binding to tissue factor in reconstituted phospholipid vesicles: Induction of cooperativity by phosphatidylserine. Biochemistry 25, 4007-20.

33. Willems GM, Giesen PL and Hermens WT (1993) Adsorption and conversion of prothrombin on a rotating disc. Blood $82,497-504$.

34. Billy $D$, Speijer $H$, Willems GM, Hemker HC and Lindhout $T$ (1995) Prothrombin activation by prothrombinase in a tubular flow reactor. $\mathrm{J}$ Biol Chem 270, 1029-34.

35. Andree HA Contino PB, Repke D, Gentry $R$ and Nemerson $Y$ (1994) Transport rate limited catalysis on macroscopic surfaces: the activation of factor $X$ in a continuous flow enzyme reactor. Biochemistry 33, 4368-74.

36. Neuenschwander PF and Morrissey JH (1994) Roles of the membrane-interactive regions of factor Vila and tissue factor. The factor Vila Gla domain is dispensable for binding to tissue factor but important for activation of factor X. J Biol Chem 269, B007-13.

37. Waxman E, Ross JB, Laue TM, Guha A, Thiruvikraman SV, Lin TC, Konigsberg WH and Nemerson $Y$ (1992) Tissue factor and its extracellular soluble domain: The relationship between intermolecular association with factor Vlla and enzymatic activity of the complex. Biochemistry 31 , 3998-4003

38. Giesen PL, Willems GM, Hemker HC and Hermens WT (1991) Membrane-mediated assembly of the prothrombinase complex. J Biol Chem 266, 18720-5. 
39. Rao LVM, Robinson $T$ and Hoang $A D$ (1992) Factor Vlla/Tissue Factor Catalyzed Activalion of Factors $I X$ and $X$ on a Cell Suraface and in Suspension: A Kinetic Study. Thromb Haemost 67. 654-9.

40. Levich VG (1962) Physiolochemical hydrodynamics, Prentice Hall, Englewood Cliffs, NJ

41. Shu FR and Wison GS (1976) Rotating ring-disk enzyme electrode for surface catalysis studies. Anal Chem $48,1679.86$.

42. Castner JF and Wingard $L B$ (1984) Mass transport and reaction kinetic parameters determined electrochemically for immobilized glucose oxidase. Biochemistry $23,2203-10$.

43. Gemmell $\mathrm{CH}$, Broze GJ Jr, Turitto $V T$ and Nemerson $Y$ (1990) Utilization of a continuous flow reactor to study the lipoprotein-associated coagulation inhibitor (LAC) that inhibits tissue factor. Blood 76, 2266-71.

44. Schoen $P$. Lindhout $T$, Willems GM and Hemker HC (1990) Continuous flow and the prothrombinase-catalyzed activation of prothrombin. Thromb Haemost 64, 542-7.

45. Bom VJ, Reinalda-Poot JH, Cupers R and Bertina RM (1990) Extrinsic activation of human blood coagulation factors $I X$ and $X$. Thromb Haemost $63,224-30$.

46. Krishnaswamy $S_{8}$ Field $K$, Edgington TS, Morrissey JH and Mann KG (1992) Role of the membrane surface in the activation of human coagulation factor $X$. J Biol Chem 267, 26110-20.

47. Nelsestuen GL, Broderius $M$ and Martin G (1976) Role of gamma-carboxyglutamic acid. Cation specificity of prothrombin and factor $X$-phospholipid binding. J Biol Chem 251, 6886-93.

48. Valentin S and Schousboe I (1996) Factor Xa enhances the binding of tissue factor pathway inhibitor to acidlic phospholipids. Thromb Haemost 75, 796-800.

49. Lindhout $T$, Salemink I, Valentin S and Willems GM (1996) Tissue Factor Pathway Inhibitor: Regulation of its inhibitory activity by phospholipid surfaces. Haemastasis 26 (Suppl 4), 89-97.

50. Kazama $Y(1997)$. The importance of the binding of factor $X a$ to phospholipids in the inhibitory mechanism of Tissue Factor Pathway Inhibitor: The transmembrane and cytoplasmic domains of Tissue Factor are not essential for the inhibitory action of tissue Factor Pathway Inhibitor. Thromb and Haemost $77,492-7$.

51. Rao LVM and Ruf W (1995) Tissue factor residues Lys(165) and Lys(166) are essential for rapid formation of the quaternary complex of tissue factor center dot Vlla with $x_{a}$ center dot tissue factor pathway inhibitor. Biochemistry 34, 10867-71. 


\title{
Chapter 5
}

\section{Tissue Factor:Factor VIla Catalyzed Factor $X$ Activation and its Inhibition by Factor Xa:Tissue Factor Pathway Inhibitor at Human Embryonic Lung Fibroblasts Adhered to a Rotating Disc}

\author{
Irene Salemink, George M. Willems, Jacob J. Briedé, H. Coenraad Hemker and \\ Theo Lindhout, submitted
}

\section{Summary}

Tissue factor (TF):factor Vlla (FVlla) mediated factor $X(F X)$ activation is inhibited by a complex of tissue factor pathway inhibitor (TFPI) and activated $F X$ (FXa). Previous studies, using TF embedded in a phospholipid membrane, have demonstrated the presence of a membrane-bound pool of full length TFPI:FXa complexes when the membrane contains phosphatidylserine (PS). In this study we investigated under what conditions such a pool of inhibitory activity could be present at the surface of TF-bearing human embryonic lung fibroblasts. Unperturbed fibroblasts did not bind annexin $\mathrm{V}$, indicating a low, if any, content of PS. Similar rate constants of inhibition, $0.5 \times 10^{8} \mathrm{M}^{-1} \mathrm{~s}^{-1}$ and $0.4 \times 10^{8} \mathrm{M}^{-1} \mathrm{~s}^{-1}$, were measured for complexes of FXa with full length TFPI (TFPI FL) or truncated TFPI (TFPl 1-161 ). These findings indicate that the presence of PS at cell surfaces is not required for an effective inhibition of TF:FVlla activity. Preincubation of the unperturbed fibroblasts with FXa:TFPI and subsequent depletion of inhibitor from the solution phase, revealed that no functional membrane-bound FXa:TFPI was present. When fibroblasts were treated with ionomycin, a calcium ionophore, the fibroblast surfaces did bind annexin $\mathrm{V}$, indicating the presence of a significant amount of PS at these cell surfaces. Incubation of these cells with FXa:TFPI, followed by a rinse of the cell surfaces, resulted in a membrane-bound pool of FXa:TFPIFL inhibitory activity that was not observed with the truncated variant FXa:TFPI ${ }_{i-161}$. It is tempting to speculate that when TF-bearing cells become apoptotic, surface-bound FXa:TFPI complexes may have an important regulatory role in the initiation of blood coagulation at these cells. 


\section{Introduction}

It is generally appreciated that tissue factor (TF), an integral membrane protein and a member of the cytokine receptor superfamily, is the principal initiator of blood coagulation in Vivo (1,2). Because excessive triggering of blood coagulation by an aberrant synthesis of TF or an increased TF activity at vascular cells has to be regarded as a major contributor to thrombogenesis, a proper regulation of TF activity is critical for the maintenance of the haemostatic balance. Neutralization of TF:FVIla catalytic activity by plasma inhibitors provides an utmost important mechanism in regulating functional TF expression at cell surfaces (See ref. 3 for a review). The main physiological inhibitor of TF-induced blood coagulation is the FXa:TFPI complex $(4,5)$.

Recently we have demonstrated that phospholipid-bound complexes of FXa with full length TFPI ( $F X a: T F P I_{F L}$ ) could provide an important pool of inhibitor that is readily available for on site regulation of TF:FVIla activity (6). The present study was undertaken to determine whether TF-bearing cells, like fibroblasts, also could provide the surface at which such a membrane-bound pool of FXa:TFPI complexes can reside after the inhibitor is depleted from the solution. TF-dependent activation of $F X$ and its inhibition by FXa:TFPI complexes was studied with fibroblasts adhered to a rotating disc. First we determined the conditions for an optimal FX activation at unperturbed fibroblast surfaces by varying FVIla and FX concentrations. Next, rate constants of inhibition of FX activation by preformed complexes of FXa and TFPI variants, having different affinities for negatively charged phospholipid membranes, were determined. Finally, we examined the effect of calcium ionophore-induced perturbation of fibroblasts on the inhibition of FX activation by FXa:TFPIFL.

\section{Materials and Methods}

Reagents. Bowine serum albumin (BSA, essentially fatty acid free) and ionomycin were obtained from Sigma (St. Louis, MO). The chromogenic substrate for FXa, S2765, was purchased from Chromogenix (Mölndal, Sweden). From Gibco BRL (Paisley, Scotlandy were obtained phosphate-buffered saline pH 7.4 (PBS), MEM (eagle) medium with glutamax-1, non-essential amino acids, penicillin-streptomycin ( $5000 \mathrm{IU} \mathrm{mL}$ ), newborn calf serum and trypsin-EDTA in HBSS. Glutardialdehyde solution (25\%) was from Merck (Darmstadt, Germany), and Bacto gelatin was bought from Difco (Detroit, MI). Oregon Green 488-labeled annexin V (annexin V-OG) was obtained from NeXins Research (Hoeven, The Netherlands). The calpain inhibitor calpeptin was bought from Merryl Dow (Cincinnati, OH). Human FVIla, FX, and FXa were prepared as previously described (6). Recombinant full length TFPI was a kind gift of Dr. T-C Wun (Monsanto Co, St. Louis, MO). The C-terminal truncated TFPI 
preparation (7) (TFPl $\left.{ }_{1-161}\right)$, which lacks the third Kunitz domain and C-terminus, was kindly supplied by Dr. O Nordfang (Nowo Nordisk, Bagsvaerd, Denmark).

Cell Cufture. Human embryonic lung fibroblasts 12002 , Flow Laboratories/lCN, Rickmansworth, UK) of passage 14 to 25 were grown to confluence in tissue culture flasks $\left(25 \mathrm{~cm}^{2}\right)$ at $37{ }^{\circ} \mathrm{C}$ and $5 \% \mathrm{CO}_{2}$ in MEM-glutamax medium supplemented with $10 \%$ newborn calf serum, $100 \mathrm{lU} \mathrm{mL} \mathrm{mL}^{-1}$ streptomycin/penicillin and $1 \%$ non-essential amino acids. Cells were passed using trypsin-EDTA and again grown to confluence in tissue culture flasks $\left(25 \mathrm{~cm}^{2}\right)$ or at discs $\left(3.14 \mathrm{~cm}^{2}\right)$.

Phase-Contrast Imaging. Positive phase-contrast images were obtained with an inverted Nikon Diaphot 200 microscope (Nikon, Tokyo, Japan) using a $40 x$ quantz oil. immersion objective (Nikon) containing a phase-plate. The phase-contrast transmission images were recorded with an infrared camera (VPM 6132 monochrome high-resolution charge-coupled device camera, Vista Co, Norbain, UK).

Fluorescence Imaging. Light from a Xenon lamp passes an excitation and neutral density filter and reaches the objective of the inverted microscope through a UV-transparent liquid light guide and a dichroic long-pass filter. The emission light passes a filter and finally reaches a low level intensified charge-coupled device camera (Photonic Sciences, Robertsbridge, UK) that works at standard video rate. Oregon Green 488 fluorescence was detected with a $485 \mathrm{~nm}$ excitation filter (bandpass $40 \mathrm{~nm}$ ), a $505 \mathrm{~nm}$ dichroic long-pass filter and a 530 emission filter (bandpass $30 \mathrm{~nm}$ ). These images were then digitized, averaged $(n=8)$, and stored after subtraction of background images.

The Rotating Disc Device. The set up used in the present study is similar to the one described previously (6). Briefly, a cylinder containing four tiny magnets is mounted on a motor with servo-controlled rotation speed. On top of the motorcontaining holder a cylindrical vessel can be placed such that the magnetic cylinder rotates closely to the bottom of the vessell. The rotating disc, which is a glass cover slip (Menzel Glaser, Braunschweig. Germany) glued on a second cylinder also containing four magnets, is placed in the vessel. Before mounting the fibroblast covered rotating disc in the vessel the vessel was incubated for 1 hour with $20 \mathrm{mg}$ $\mathrm{mL}^{-1}$ BSA in Hepes-buffer (10 $\mathrm{mM}$ Hepes, $\left.\mathrm{pH} 7.45,135 \mathrm{mM} \mathrm{NaCl}\right)$. Thereafter the high content BSA Hepes-buffer was replaced by a HBSA buffer (10 mM Hepes, pH $7.45,135 \mathrm{mM} \mathrm{NaCl}, 1 \mathrm{mM} \mathrm{MgCl}, 4 \mathrm{mM} \mathrm{KCl}, 11 \mathrm{mM}$ glucose and $2 \mathrm{mg} \mathrm{mL}^{-1} \mathrm{BSA}$ ).

Preparation of Fibroblast-Covered Discs. The rotating discs were soaked overnight in a solution of $1 \%(\mathrm{w} / \mathrm{v})$ glutardialdehyde in water, then rinsed with water and stored in $70 \%$ ethanol. Upon use, the discs were placed in a 6 well cluster tissue culture plate (Costar, Cambridge, MA) and the ethanol was evaporated in the sterile airflow of the flow cabinet. The discs were rinsed with PBS and incubated with a sterile $1 \%(w / v)$ gelatin solution (in PBS) at $37{ }^{\circ} \mathrm{C}$ for $30 \mathrm{~min}$. The gelatin solution was aspirated and subsequently the gelatin was cross-linked by adding sterile $0.5 \%(\mathrm{v} / \mathrm{V})$ glutardialdehyde solution. The discs were washed twice with PBS, and once with 
supplemented MEM-medium. The cell suspension was added and the tissue culture plate was placed in the incubator where the cells at the discs were grown to confluence at $37^{\circ} \mathrm{C}$ and $5 \% \mathrm{CO}_{2}$.

Measurement of TF:FVIIa Activity. The TF:FVlla activity was assessed from the FXa generation following the addition of FX (100 nM). Timed samples were taken from the reaction mixture and collected into polystyrene cuvettes containing TrisEDTA buffer ( $50 \mathrm{mM}$ Tris-HCl, $\mathrm{pH} 7.9,175 \mathrm{mM} \mathrm{NaCl}, 20 \mathrm{mM}$ EDTA and $0.5 \mathrm{mg} \mathrm{mL}^{-1}$ $B S A$, total volume of $450 \mu \mathrm{L}$ ). To determine the amount of FXa present in the sample, $50 \mu \mathrm{L}$ of $3 \mathrm{mM}$ chromogenic substrate $\mathrm{S} 2765$ was added to the cuvette, and conversion of the chromogenic substrate was followed at $37^{\circ} \mathrm{C}$ on a dual wavelength spectrophotometer at $405 \mathrm{~nm}$ (reference wavelength $500 \mathrm{~nm}$ ). The FXa concentrations were calculated from standard curves obtained with known amounts of the enzyme. All procedures were performed at $37^{\circ} \mathrm{C}$.

FXa Generation at the Surface of a Fibroblasts-Covered Rotating Disc. To remove cell-particles and remnants possibly present, the vessel and fibroblast covered disc were flushed for $15 \mathrm{~min}$ with HBSA buffer $\left(10 \mathrm{~mL} \mathrm{~min}^{-1}\right.$ " using a Minipuls II pump, Gilson, Villiers-le-Bel, France) before every experiment. The disc was spun at a low rotation rate $\left(6.3 \mathrm{rad} \mathrm{s}^{-1}\right)$ in order to avoid the exposure of the cells to high shear stress. The vessel and disc were flushed ( $5 \mathrm{~min}$ at $\left.10 \mathrm{~mL} \mathrm{~min}^{-1}\right)$ with an HBSA-Ca ${ }^{2+}$ buffer (HBSA buffer containing $3 \mathrm{mM} \mathrm{CaCl}_{2}$ ). FVlla $(0.5 \mathrm{nM}$ ) was added to the vessel and incubated for $5 \mathrm{~min}$. Then, the angular velocity was increased to 63 rad $s^{-1}$ and $\mathrm{FX}(100 \mathrm{nM})$ was added. Timed samples were collected in Tris-EDTA buffer from the reaction mixture in the vessel and assayed for FXa as described above. All procedures were performed at $37^{\circ} \mathrm{C}$. To estimate the contribution of fluid phase microparticles or cell fragments to the FX activation, additional samples (100 $\mu \mathrm{L}$ ) were taken from the vessell at $0.5,4.5$ and $8 \mathrm{~min}$. These samples were placed in a test tube at $37{ }^{\circ} \mathrm{C}$ to assess progressing $\mathrm{FXa}$ generation independent of that produced at the rotating disc surface. It appeared that this fluid phase rate of $\mathrm{FXa}$ generation increased linearly with time: $\mathrm{V}=\mathrm{Ct}$, with a proportionality constant $\mathrm{C}$ ( $\mathrm{nM}$ $\mathrm{min}^{-2}$ ) estimated by linear regression. This empirical relation allows estimation of the solution phase $\mathrm{FXa}$ production: $\mathrm{FXa}^{\mathrm{sol}}=0.5 \mathrm{C} \mathrm{t}^{2}$. $\mathrm{FXa}$ production at surfaces of fibroblasts adhered to the rotating disc can thus be calculated by subtracting $\mathrm{FXa}^{\mathrm{sol}}$ from the total amount of FXa generated in the vessel.

Inhibition of TF:FVII Activity. All inhibition experiments were carried out with preformed FXa:TFPI complexes. These complexes were prepared by incubation of FXa and TFPI at equimolar concentrations (50 nM) for 30 min at $37^{\circ} \mathrm{C}$ in an HBSA$\mathrm{Ca}^{2+}$ buffer. This incubation time was sufficiently long to obtain an equilibrium in complex formation ( $95 \%$ of $\mathrm{FXa}$ in complex), as established by measuring the free FXa concentration with chromogenic substrate S2765. The inhibitory activity of FXa:TFPI was assessed as follows. The vessel and fibroblast-covered disc (rotating at $\left.6.3 \mathrm{rad} \mathrm{s}^{-1}\right)$ were flushed with HBSA buffer $\left(15 \mathrm{~min}\right.$ at $\left.10 \mathrm{~mL} \mathrm{~min}{ }^{-1}\right)$ followed by a 
flush with $\mathrm{HBSA}_{-\mathrm{Ca}^{2+}}$ buffer ( $5 \mathrm{~min}$ at $10 \mathrm{~mL} \mathrm{~min}^{-1}$ ). The angular velocity was set at $63 \mathrm{rad} \mathrm{s}^{-9}$ and $\mathrm{FX}$ activation was started by the simultaneous addition of FVIlla $(0.5$ $\mathrm{nM})$ and $\mathrm{FX}(100 \mathrm{nM})$. Then at $t=5.5 \mathrm{~min}$, preformed FXa:TFPI complexes were added to the reaction solution and timed sampling from the reaction solution was continued.

In order to measure the inhibitory activity of surface-bound FXa:TFPI the rotating fibroblast-covered disc was pre-incubated for 10 min with 0.4 nM FXa:TFPI in the absence of FVIla at $6.3 \mathrm{rad} \mathrm{s} \mathrm{s}^{-1}$. The solution was subsequently depleted of inhibitor by flushing $\left(10 \mathrm{~mL} \mathrm{~min}^{-1}\right)$ for $5 \mathrm{~min}$ with $\mathrm{HBSA}-\mathrm{Ca}^{2+}$ buffer. $\mathrm{FX}$ activation was started by the addition of FX $(100 \mathrm{nM})$ and FVlla $(0.5 \mathrm{nM})$. Timed samples were taken and assayed for FXa activity. This experiment was performed also on perturbed fibroblasts that exposed PS in their outer membrane-leaflet. To this end the fibroblasts at the disc were incubated with calpeptin ( $30 \mu \mathrm{M})$ in MEM medium at $37^{\circ} \mathrm{C}$ for $30 \mathrm{~min}$. Then the disc was placed in the vessel, flushed with $\mathrm{HBSA}-\mathrm{Ca}^{2+}$ buffer, incubated with ionomycin $(5 \mu \mathrm{M})$ for $30 \mathrm{~min}$ and flushed again.

Data Analysis.

Dependency of the FX Activation Rate on the FX Concentration. Kinetics of FX activation were analyzed using the Michaelis-Menten formula

$$
V_{o b s}=V_{\max }[F X] /\left([F X]+K_{m, a p p}\right)
$$

that relates $V_{\text {obs }}$ (the initial rate of $F X$ activation) to $V_{\max }$ (the initial rate at saturating FX concentrations), [FX] the FX concentration, and $K_{\text {mapp }}$ the apparent Michaelis constant. The parameters $V_{\max }$ and $K_{m \text {,app }}$ were determined by least squares fitting of eq 1 to the measurements of $V_{\text {obs }}$.

FVIIa Concentration-Dependent FX Activation. As the catalytic efficiency of FVlla in complex with TF is several orders of magnitude higher than of free FVIla, the observed FX generation rate, $V_{o b s}$, refiects the formation of the binary TF:FVIla complex and is described by the formula

$$
V_{o b s}=V_{\max }[F V \| l a] /\left([F V \| l a]+K_{d}\right)
$$

with [FVIla] the free FVIla concentration, $K_{d}$ the apparent dissociation constant of the TF:FVlla complex and $V_{\max }$ the rate of FXa generation at saturating FVlla concentration. The parameters $V_{\max }$ and $K_{d}$ were determined by least squares fitting of eq 2 to the measurements of $V_{o b s .}$

Inhibition of TF:FVIIa-Mediated FX Activation by Preformed FXa:TFPI Complexes. In our experiments we determined for each fibroblast-covered rotating disc the initial rate of FXa activation in the absence of inhibitor. Subsequently, after 
$5.5 \mathrm{~min}$, inhibitor complex was added. The uninhibited part of the FXa generation curve exhibited a small decline in the FXa generation rate. This effect was heuristically modeled by assuming a non-specific mono-exponential decay of the FXa activation rate:

$$
[F \times a]_{1}=V_{0}\left(1-e^{-\kappa} \cdot t / k\right.
$$

with $\mathrm{k}$ the first order rate constant of non-specific decay of the FX converting activity, accounting for substrate depletion, loss of TF-activity etc., and $V_{0}$ the initial rate of FXa generation. In the presence of FXa:TFPI, inhibition of FXa generation reflects the formation of quaternary TF:FVIla:TFPI:FXa complexes and the corresponding decline of TF:FVIla activity, which for any fixed concentration of inhibitor, can be described as a pseudo-first order process $(8,9)$. Therefore the inhibited FXa generation, caused by the addition of inhibitor at $t=5.5 \mathrm{~min}$, can be described by a mono-exponential decay of the FXa generation rate, with an apparent decay constant $k$ that depends linearly on the inhibitor concentration. The FXa generation $[\mathrm{FXa}]$, can thus be expressed for $t>5.5 \mathrm{~min}$ as

$$
[F X a]_{i}=[F X a]_{5.5}+V_{0} e^{-k 5.5}\left(1-e^{-k(t-5.5)}\right) / k
$$

with $\mathrm{k}$ the pseudo first order rate constant of inhibition. The constants $V_{0}, k$ and $k$ are estimated by a simultaneous least squares fit of eqs $3 a$ and $b$ to the experimental data, consisting of the uninhibited and the inhibited part of the FXa generation curve.

\section{Results and Discussion}

FX Activation at the Surface of a Rotating Disc Covered with Fibroblasts. A typical FXa generation curve as measured in the rotating disc system is depicted in Fig. 1 (closed circles). As shown, the amount of FXa present in the reaction solution increases linearly in time. Since this experiment was performed at a rotation rate of $63 \mathrm{rad} \mathrm{s}^{-1}$, corresponding to a wall shear rate of $3681 \mathrm{~s}^{-1}$ at the edge of the disc (10) part of this FX activating activity could arise from the release of vesicles rich in TF (11-13). Determination of ongoing $F X$ activation in aliquots that were removed at $t=$ $0.5,4.5$ and $8 \mathrm{~min}$ from the reaction solution revealed a small contribution of particle related FXa generation to total FXa generation. Correction of total FXa generation 


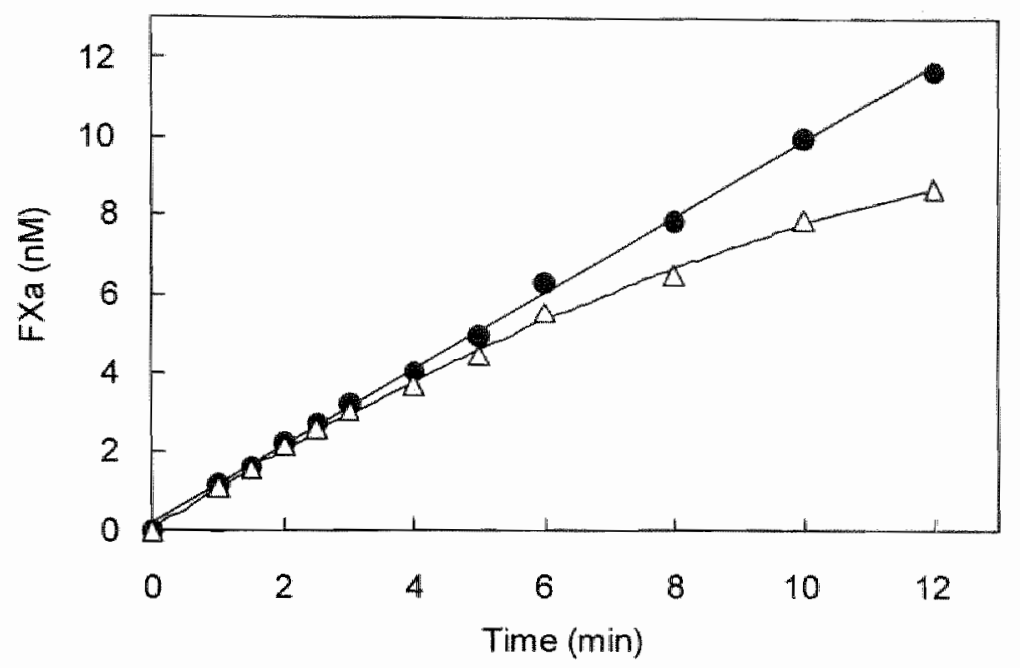

Figure 1 FXa generation at fibroblast surfaces. FVlla $(0.5 \mathrm{nM})$ and $\mathrm{FX}(100 \mathrm{nM})$ in HBSA-Ca ${ }^{2+}$ buffer were added to a fibroblast-covered rotating disc (63 rad $s^{-1}$ ). Timed samples were taken and assayed for FXa (-). Simultaneously, aliquots were transferred to test tubes and sampling for FXa was continued to determine the rate of FXa generation in the absence of the rotating disc. The FXa generation curve in the presence of the rotating disc was corrected for fluid phase FXa generation $(\Delta)$ as described under Materials and Methods. Ail procedures were performed at $37^{\circ} \mathrm{C}$.

for this solution phase dependent FXa generation is depicted in Fig. 1 (open triangles). It is clearly shown that the contribution of solution phase FXa generation increases in time yielding $20 \%$ of the total $\mathrm{FXa}, 10 \mathrm{~min}$ after the start of the activation experiment. To limit the contribution of solution phase FXa generation, rotating disc experiment were conducted for less than 10 minutes after the start of the $F X$ activation.

The Rate of FX Activation at Fibroblast Surfaces as a Function of the FX Concentration. Initial experiments indicated a large variation in initial rates of $F X$ activation when different fibroblast containing discs were used under identical experimental conditions $\left(V_{0}=2.5 \pm 1.3\right.$; mean $\left.\pm S D, n=18\right)$. For each disc initial rates of $\mathrm{FX}$ activation were therefore measured at one fixed $(400 \mathrm{nM})$ and one varying concentration of $\mathrm{FX}$. The rate constant obtained with $400 \mathrm{nM} F X$ was used to normalize the rate constants at varying $\mathrm{FX}$ concentrations (Fig. 2). It is shown that the rate of $F X$ activation at the rotating surface increases with the $F X$ concentration until saturation. By fitting eq 1 to the experimental data, a value of $95 \mathrm{nM}$ for the 
apparent $K_{m}\left(K_{m}\right.$, app $)$ was estimated. This $K_{m \text { m. app }}$ value for $F X$ activation at surfaces of unperturbed fibroblast under flow conditions is lower then the values previously reported for cell surfaces under static conditions. These values ranged from $206 \mathrm{nM}$ for $0 \mathrm{C}-2008$ monolayers to $480 \mathrm{nM}$ for fibroblast-monolayers $(14,15)$. The higher $\mathrm{K}_{\mathrm{m}}$, app values probably reflect the effect of transport-limited supply of substrate under the static conditions of the latter experiments. Interestingly, the $K_{m}$, app value of $95 \mathrm{nM}$ reported here is similar to the $K_{m \text {, app }}$ of $110 \mathrm{nM}$ found for TF-containing membranes, composed of $25 \mathrm{~mol} \% \mathrm{PS}$ and $75 \mathrm{~mol} \% \mathrm{PC}$, at the surface of a rotating disc (6). This value, in turn, is at least two orders of magnitude lower than the $K_{m}$ app reported for TF embedded in PC. The inability of these cell surfaces to bind annexin V (data not shown) however suggests a low PS content, if present at all. It could be argued that FXa generation is not produced at the cell surface but by TF-bearing microparticles shed by the fibroblasts adhered to the rotating disc (15). We note, however, that under the conditions of our experiments microparticles did not significantly contribute to initial rates of $F X$ activation (Fig. 1).

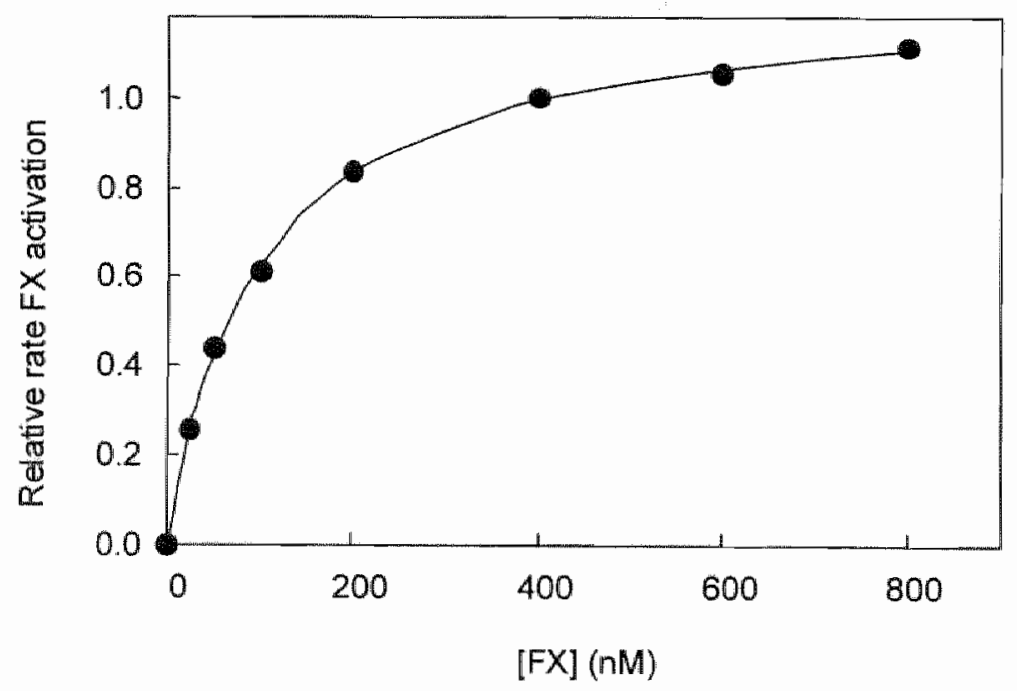

Figure 2 Rate of $\mathrm{FX}$ activation at fibroblast surfaces as a function of $\mathrm{FX}$ concentration. The fibroblast surface was incubated for $5 \mathrm{~min}$ with $0.5 \mathrm{nM}$ FVlla, and subsequently varying concentrations of $F X$ were added. Timed samples were assayed for FXa and the rates of FX activation were determined as described under Material and Methods. Indicated is the FXa generation relative to that measured at $400 \mathrm{nM} F X$. The solid line is the best fit of eq 1 to the data. 
Dependency of the Rate of FX Activation at Fibroblast Surfaces on the FVIa Concentration. Initial rates of FX activation were measured at a single fibroblastcoated disc with $100 \mathrm{nM} \mathrm{FX}$ and two FVIla concentrations, namely $0.5 \mathrm{nM}$ FVIla and a concentration that varied from 0-1 nM FVIIa. Fig. 3 shows the initial rates of $\mathrm{FXa}$ generation, relative to the rate obtained with $0.5 \mathrm{nM}$ FVIla, as a function of the FVlla concentration. The solid line represents the best fit of eq 2 to the experimental data. The fit yielded a dissociation constant $\left(K_{d}\right)$ of $0.05 \mathrm{nM}$. Thus the FVIla concentration of $0.5 \mathrm{nM}$ that was used in further experiments is sufficient to saturate more than $90 \%$ of the functional TF present at the fibroblast surface. The dissociation constant of FVlla binding to fibroblasts reported here is much lower than the values that have been reported for OC-2008 monolayers $(0.97 \mathrm{nM})$ and for OC-2088 cell lysate $(0.36$ nM) (14). The affinity of FVlla for unperturbed fibroblasts is higher than observed with TF-containing neutral phospholipid bilayers but similar to TF-containing membranes composed of $25 \mathrm{~mol} \%$ PS and $75 \mathrm{~mol} \%$ PC (6). Yet, the presence of PS on these unperturbed cell surfaces could not be probed with fluorescent-labeled annexin $V$ (data not shown). This observation rules out the possibility that FVlla and/or formed FXa causes significant PS exposure at the outer leafiet of the plasma membrane of the fibroblast as suggested by several investigators (16-18). At present we have no explanation for the unexpected high affinity of FVIla for TF exposed by the fibroblasts at a cell membrane that is apparently devoid of PS.

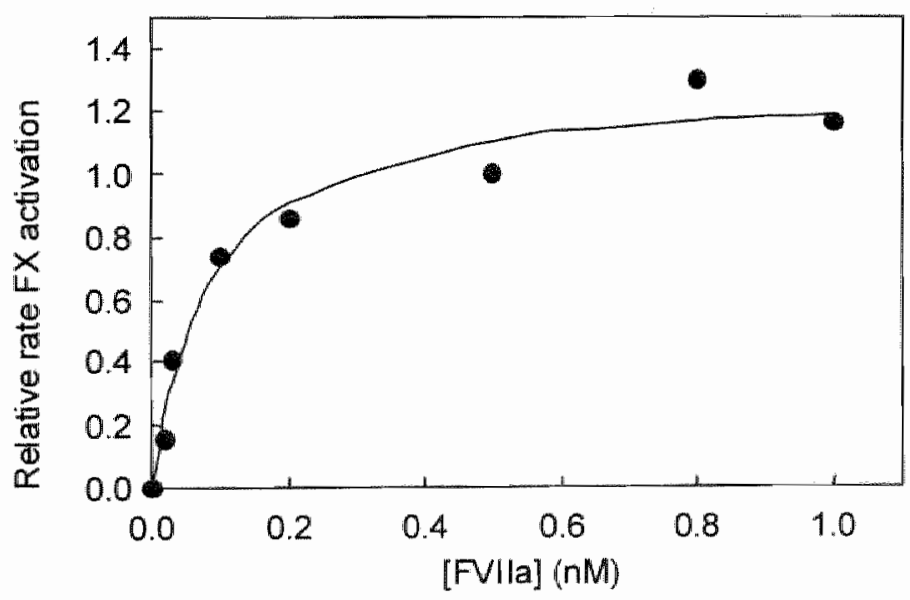

Figure 3 Rate of FX activation at fibroblast surfaces as a function of FVlla concentration. The fibroblast surface was incubated for $5 \mathrm{~min}$ with varying concentrations of FVlla. The reaction was started by the addition of $\mathrm{FX}(100 \mathrm{nM})$ and the relative rates of FXa generation were determined. The solid line represents the best fit of eq 2 to the data. 
Inthibition of Cell Membrane-Associated TFifvIla as a Function of the Concentration of FXa.TFPI. In a successive set of experiments we assessed the

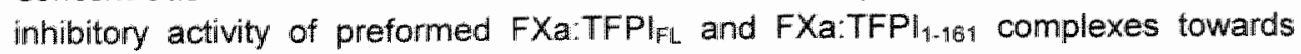
TF:FVlla-catalyzed FX activation at fibroblast-covered rotating discs. Before adding the inhibitor we first determined the rate of $F X$ activation that was used to normalize the FXa generation curve. Fig. 4A shows the results of a typical experiment where FX (100 nM) was activated at the fibroblast surfaces on a rotating disc in the presence of $0.5 \mathrm{nM}$ FVlla, followed (after 5.5 minutes) by the addition of buffer (closed circles) or $0.05 \mathrm{nM}$ preformed FXa:TFP| $\left.\right|_{\mathrm{FL}}$ or FXa:TFPI $\|_{1-181}$ complex (open and closed triangles, respectively). FXa generation curves were analyzed by a least square fit of eq $3 a$ and $3 b$ to the data. The pseudo-first order rate constants of inhibition were replotted versus the inhibitor concentration (Fig. 4B). Linear regression to these data resulted in similar second order rate constants of inhibition, namely $0.4 \times 10^{8} \mathrm{M}^{-1} \mathrm{~s}^{-1}$ and $0.5 \times 10^{8} \mathrm{M}^{-1} \mathrm{~s}^{-1}$, for FXa:TFPI $1-161$ and FXa:TFPI $\mathrm{FL}$ respectively. Our data are in agreement with the observations made by Hamamoto et al (19) who show a significant inhibition of TF:FVIla at J82 carcinoma cells by both FXa:TFPl $1-161$ and FXa:TFPl ${ }_{F L}$. We note that in spite of the absence of detectable PS, the second order rate constants of inhibition reported here for unperturbed fibroblast surfaces, are higher than the values reported for TF embedded in pure PC and are more close to the value found for TF embedded in a PS containing phospholipid membrane (6).

Inhibition of TF:FVIIa-Catalyzed FX Activation by Cell-Surface-Bound FXa:TFPI complex. The next question we addressed was whether unperturbed fibroblast surfaces are able to bind FXa:TFPI $\left.\right|_{F L}$ complexes so that when the inhibitor is depleted from the fluid phase, FXa:TFPI inhibitory activity bound to the cell surfaces can still be found. Rotating discs $\left(6.3 \mathrm{rad} \mathrm{s}^{-1}\right)$ covered with fibroblasts were incubated with $0.4 \mathrm{nM}$ FXa:TFP $\|_{\mathrm{FL}}$ for 20 minutes in order to bind the TFPl:FXa complex. Then, the reaction vessel was flushed with $\mathrm{HBSA}-\mathrm{Ca}^{2+}$ buffer during $5 \mathrm{~min}$ at $10 \mathrm{~mL} \mathrm{~min}$. The angular velocity of the disc was then increased to 63 rad $\mathrm{s}^{\mathrm{*}}$ and $\mathrm{FX}(100 \mathrm{nM})$ and FVIla $(0.5 \mathrm{nM})$ were added simultaneously. FXa generation curves on fibroblasts that were first preincubated with $F X_{\text {X:TFPI }}$ and then rinsed before the addition of FX and FVlla were identical to those without the preincubation step. Apparently, the inhibitor activity was completely washed-out. This finding is compatible with the notion that FXa:TFPlFL complexes only have a long residence time on surfaces with a sufficient high PS content (6).

To evaluate the possible role of PS at fibroblast surfaces in the high affinity binding of FXa:TFPIFL, similar experiments were performed with fibroblasts that were treated with the calcium ionophore ionomycin $\left(1 \mu \mathrm{g} \mu \mathrm{L}^{-1}\right)$. PS exposure could be demonstrated by the ability of these cells to bind OG-labeled annexin $V$. The ionomycin treatment, however, also severely disrupted the integrity of the plasma 

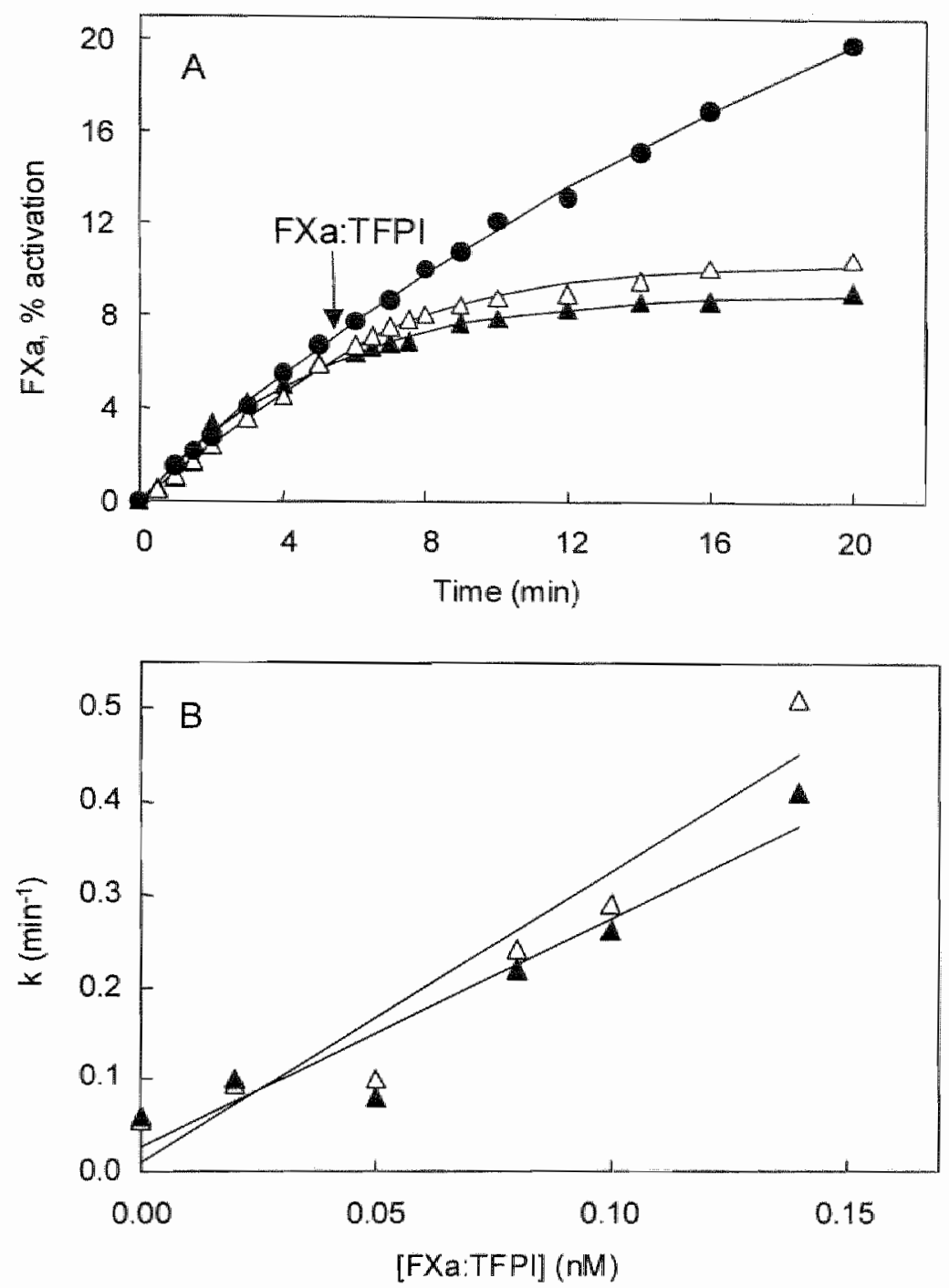

Figure 4 Inhibitory activity of FXa:TFPIFL towards TF:FVlla at a fibroblast surface. Panell A: FX activation was started by the addition of FVlla $(0.5 \mathrm{nM})$ and $\mathrm{FX}(100 \mathrm{nM})$.

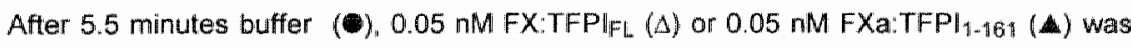
added to the reaction solution. Samples were taken at the indicated time points and assayed for FXa activity. The solid lines are drawn according to eqs $3 a$ and $3 \mathrm{~b}$. Panel $\mathrm{B}$ represents the pseudo-first order rate constants of inhibilion, $k$, yielded by the fit procedure as a function of the FX:TFPlFL $(\Delta)$ ar FXa:TFPI T-161 $_{\text {(A) }}$ concentration. 
membrane of fibroblasts, i.e. shedding of microparticles (data not shown). These changes in morphology most likely result from calpain-catalyzed degradation of the cytoskeleton $(20,21)$. Incubation of the fibrobilasts with calpeptin, a calpain inhibitor, followed by ionomycin treatment resulted in exposure of PS in the outer leaflet of the membrane without the concomitant shedding of microparticles (Fig. 5). Indeed, when FXa generation of perturbed fibroblasts was studied, no significant FXa generation was measured in the solution phase of the reaction system.

Fibroblasts pretreated with calpeptin and ionomycin were incubated with FXa:TFPl $\mathrm{FL}(0.4 \mathrm{nM}$ for 20 min). Subsequently, the reaction vessel was flushed with HBSA-Ca ${ }^{2+}$ buffer during $5 \mathrm{~min}$ at $10 \mathrm{~mL} \mathrm{~min}^{-1}$ and $0.5 \mathrm{nM}$ FVIla and $100 \mathrm{nM} \mathrm{FX}$ were added simultaneously. The initial rate of $\mathrm{FXa}$ generation for ionomycin perturbed cells that were not pre-incubated with FXa:TFPIFL was $3.7 \mathrm{nM} \mathrm{min}{ }^{-1}$. In contrast, the fibroblasts that were preincubated with FXa:TFPI $\left.\right|_{F L}$ showed a markedly reduced initial rate of FXa generation. Moreover, the FX activation was completely abrogated after about 8 minutes. These findings show, as expected, that

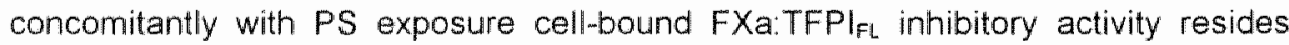
after depletion of fluid phase inhibitor activity. The residence of inhibitory activity at PS exposing fibroblasts was not abserved with FXa:TFPI 1 161, which confirms the suggestion of Hamamoto et al (19) that the third Kunitz domain and/or C-terminus of TFPI may play an important role in the interaction of FXa:TFP\| binding to the cell surface.
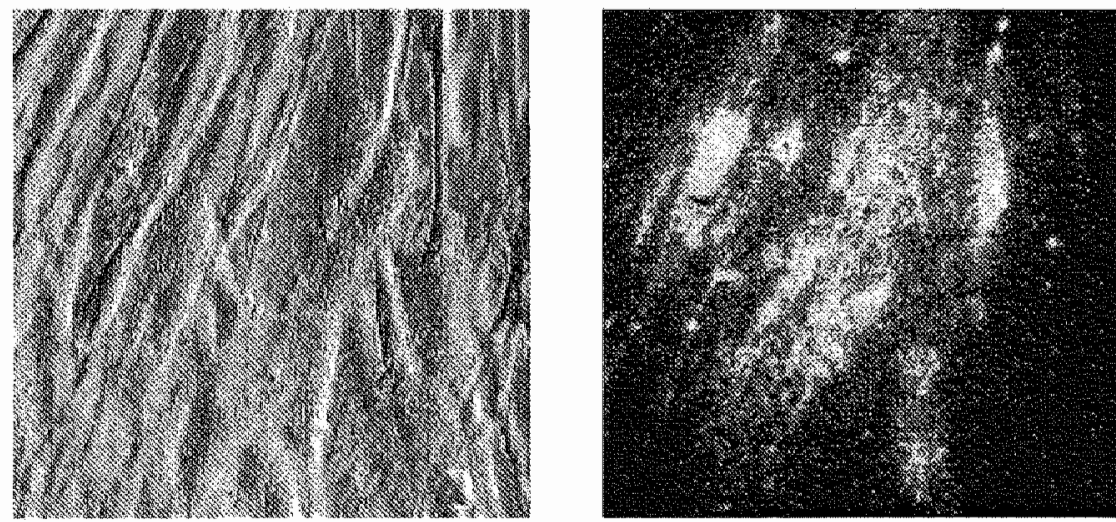

Figure 5 PS exposure of ionomycin and calpeptin treated fibroblasts. Fibroblasts were loaded with the calpain inhibitor calpeptin $(30 \mu \mathrm{M})$ prior to a 30 -minute exposure to conomycin $(5 \mu M)$ in Hepes-Ca ${ }^{2+}$ buffer. Panel $A$, phase contrast image. Panel $B$, matching fluorescence image of fibroblasts surface shown in panel $A$, after $10 \mathrm{~min}$ incubation with OG-labeled annexin $\mathrm{V}\left(1 \mu \mathrm{mg} \mathrm{L}^{-1}\right)$. 


\section{Concluding Remarks}

Taken together, our present data suggest that the pool of FXa:TFPlFL bound to negatively charged phospholipids is a major contributor to the overall inhibition of the TF:FVlla activity at perturbed, that is PS exposing, cell surfaces but not at unperturbed cells. Whether this is a physiological important mechanism of localizing TFPI inhibitory activity remains to be established. It, however "offers an interesting possibility for apoptopic. TF-bearing cells to control TF-induced blood coagulation at their surface.

\section{References}

1. Nemerson $Y(1988)$ Tissue factor and haemostasis. Blood $74,1-8$.

2. Rapaport SI, Rao LVM (1995) The tissue factor pathway: How it has become a "prima ballerina". Thromb and Haemost 74, 7-17.

3. Rao LVM, Pendurthi UR (1998) Tissue factor on cells. Blood Coag Fibrinol 9 Suppl 1:S27-35.

4. Broze GJ Jr: Girard TJ, Novolny WF (1990). Regulation of coagulation by a multivalent Kunitztype inhibitor. Biochemistry 29, 7539-46.

5. Rapaport si (1991) The extrinsic pathway inhibitor: A regulator of tissue factor-dependent blood coagulation. Thromb Haemost 66, 6-15.

6. Salemink I, Franssen $\sqrt{ }$, Willems $G$ M. Hemker HC, Lindhout $T$ (1999) Inhibition of tissue factor:factor Vlla catalyzed factor $X$ activation and inhibition by factor Xa:tissue factor pathway inhibitor: A rotating disc study on the effect of phospholipid membrane composition. $\mathrm{J}$ Biol Chem 274, 28225-32.

7. Petersen JG, Meyn G, Rasmussen JS, PetersenJ. Bjön SE, Jonassen I, Christiansen L, Nordfang $O$ (1993) Characterization of human tissue factor pathway inhibitor variants expressed in Saccharomyces cerevisiae. J Biol Chem 268, 13344-51.

8. Lindhout T, Franssen J, Willems GM (1995) Kinetics of the inhibition of tissue factor-factor Vlia by tissue factor pathway inhibitor. Thromb Haemost $74,910-5$.

9. Baugh RJ, Broze GJ Jr, Krishnaswamy $S$ (1998) Regulation of extrinsic pathway factor Xa formation by tissue factor pathway inhibitor. $J$ Biol Chem $273,4378-86$.

10. Cochran WG (1934) The flow due to a rotating disc. Proc Cambridge Phil Soc 30,365

11. Stein $\mathrm{JM}_{4}$ Luzio JP (1991) Ectocytosis caused by sublytic autologous complement attack on human neutrophils. The sorting of endogenous plasma-membrane proteins and lipids into shed vesicles. Biochem J $274,381-6$.

12. Lee $\mathrm{TL}$, Lin $\mathrm{YC}$, Mochitate $K$, Grinnell $F$ (1993) Stress-relaxation of fibroblasts in collagen matrices triggers ectocytosis of plasma membrane vesicles containing actin, annexins $\|$ and $V I$, and beta $\|$ integrin receptors, J Cell Sici 105, 167-77. 
13. Carson SD, Perry GA, Pirruccello SJ (1994) Fibroblast tissue factor: Calcium and lonophore induce shape changes, release of membrane vesicles, and redistribution of tissue factor antigen un addition to increased procoagulant activity. Blood 84, 526-34.

14. Rao LVM, Robinson T, Hoang AD (1992) Factor Vlla/tissue factor-catalyzed activation of factors $\mathbb{X}$ and $X$ on a cell surface and in suspension: A kinetic study. Thromb Haemost $67,654-9$.

15. Le DT, Rapaport SI, Rao LVM (1994) Studies of the mechanism for enhanced cell surface factor Vila/tissue factor activation of factor $X$ on fibroblast monolayers after their exposure to $\mathbb{N}$ ethylmaleimide. Thromb Haemost 72, 848-55.

16. Inuyama $H$, Saito $T$, Takagi J, Saito $Y$ (1997) Factor $X$-dependent, thrombin-generating activities on a neuroblastoma cell and their disappearance upon differentiation. J Cell Physiol 173, 406-14.

17. Bouchard $B A$, Shatos MA, Tracy PB (1997) Human brain pericytes differentially regulate expression of procoagulant enzyme complexes comprising the extrinsic pathway of blood coagulation. Arterioscler Thromb Vasc Bioll 17, 1 $\approx 9$.

18. Camerer $E$, Rottingen $J_{A}$, Iversen JG, Prydz $H(1996)$ Coagulation factors $V I I$ and $X$ induce $\mathrm{Ca}^{2 *}$ oscillations in Madin-Darby canine kidney cells only when proteolytically active. J Biol Chem 271 , 29034-42.

19. Hamamoto $T$, Yamamolo $M$, Nordfang $O$, Petersen JG, Foster DC, Kissiel $W$ (1993) Inhibitory properties of full-length and truncated recombinant tissue factor pathway inhibitor (TFPI). Evidence that the third Kunitz-type domain of TFPI is not essential for the inhibition of factor VIlatissue factor complexes on cell surfaces. $₫$ Biol Chem 268, 8704-10.

20. Klee CB, Crouch TH, Richman PG. Calmodulin (1980) Annu Rev Biochem 49, 489-515.

21. Bach R, Rifkin DB (1990) Expression of tissue factor procoagulant activity: Regulation by cytosolic calcium. Proc Natl Acad Sci USA 87, 6995-99. 


\title{
Chapter 6
}

\section{Antibodies to $\beta_{2}$-Glycoprotein I from Patients with Antiphospholipid Syndrome Suppress the Inhibitory Activity of Tissue Factor Pathway Inhibitor}

\author{
Irene Salemink, George M.Willems, Monica Galli, Edlouard Bevers and \\ Theo Lindhout, submitted.
}

\section{Summary}

Anionic phospholipid membranes have a dual role in blood coagulation: they are essential for initiation and propagation as well as termination of the blood coagulation process. Patients with the anti-phospholipid syndrome (APS) carrying

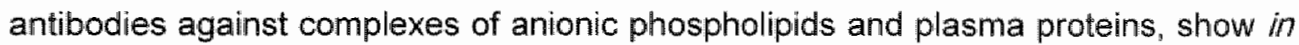
vitro inhibited phospholipid dependent coagulation reactions, whereas in vivo the presence of these antibodies is associated with an increased risk of thrombosis. In this study we focussed on the effects of these anti-phospholipid antibodies on the regulation of TF-mediated factor $\mathrm{Xa}(\mathrm{FXa})$ generation in plasma. Initial experiments, monitoring the tissue factor (TF):FVlla-catalysed FX activation in plasma of three patients with APS, revealed an increased FXa generation compared to normal plasma. We hypothesised that anti-phospholipid antibodies interfere with the phospholipid-dependent inhibition by tissue factor pathway inhibitor (TFPI) of TFinduced coagulation. Total-lgG, anti-cardiolipin-lgG ( $(\mathrm{CL})$ isolated by adsorption to cardiolipin-containing liposomes and anti- $\beta_{2} \mathrm{GPI}-\mathrm{IgG}$ isolated by immobilised $\beta_{2} \mathrm{GPI}$, all stimulated TF-induced FXa generation in normal plasma. In contrast thrombin generation in normal plasma appeared not to be influenced by the addition of anti$\beta_{2}$ GPI-IgG. However, when recombinant full length TFPI $(5 \mathrm{nM})$ was added to normal plasma, anti- $\beta_{2} G P I-\lg G$ strongly enhanced both $F X a$ and thrombin generation. This procoagulant activity was not observed when the patient's IgG was depleted of anti$\beta_{2} \mathrm{GPI}-\mathrm{IgG}$ or when normal plasma was depleted of $\beta_{2} \mathrm{GPI}$. Taken together, these data suggest that anti- $\beta_{2}$ GPI-IgG from patients with APS is associated with an impaired TFPI-dependent inhibition of TF-induced coagulation, resulting in an increased FXa and thrombin formation. 


\section{Introduction}

The dinical manifestations associated with the antiphospholipid syndrome (APS) are arterial and/or venous thrombosis, thrombocytopenia and recurrent abortion (1-5). The occurrence of thrombosis is closely related to the presence of circulating Lupus anticoagulants and IgG class anticardiolipin antibodies $(a C L)(6,7)$. It has been demonstrated that these antibodies are not directed against phospholipids per se but against phospholipid-bound plasma proteins, e.g. prothrombin and $\beta_{2}$-glycoprotein I $\left(\beta_{2} \mathrm{GPI}\right)(8-12)$. Laboratory tests have indicated that these so-called antiphospholipid antibodies inhibit phospholipid-dependent blood coagulation reactions (13). That is, the activated partial thromboplastin time (aPTT) and dilute Russell viper venom time (dRWT) performed with the plasmas of patients with APS are often prolonged. This in vitro anticoagulant activity seems paradoxical as these patients exhibit an increased risk of thrombosis. However, we note that both amplification and termination reactions of the blood coagulation process are greatly enhanced at anionic phospholipid membranes (14). Hence, it is quite feasible that competition between antiphospholipid antibodies and blood coagulation proteins for these membranes interferes with both activation and inactivation reactions. Various mechanisms for the anticoagulant effects as well as for the procoagulant effects (1521) of antibodies to lipid-bound proteins have been proposed. In spite of numerous studies, the mechanisms that explain the prothrombotic activity of the antiphospholipid antibodies remain, as yet, uncertain.

New insights in the process of initiation and regulation of blood coagulation focus on the role of tissue factor in complex with plasma FVII(a). It is now generally appreciated that the TF:FVIla complex plays a crucial role in the initiation of haemostasis both under normal and pathological conditions (see Ref 22 for a review). The TF: FVlla activity is tightly regulated by tissue factor pathway inhibitor (TFPI). TFPI inhibits the generation of FXa and FIXa by TF:FVlla in a unique manner. First, TFPI binds to FXa and then in a second step, a quaternary complex between FXa:TFPI and TF:FVIla is formed, thereby neutralizing the proteolytic activity of the TF:FVlla complex (23).

A recent study on the mechanism of inhibition has indicated that anionic phospholipids might be crucial to the inhibitory activity of FXa:TFPI (24). Thus, adsorption of anti- $\beta_{2}$ GPI. $\beta_{2} \mathrm{GPI}$ complexes to these phospholipids potentially interferes with the inhibitory effect of FXa:TFPI on the FXa generation. Whether this interference results in an overall enhanced FXa generation depends on the inhibitory effect these antibodies also may have on the phospholipid-dependent activation of $F X$. The present study demonstrates an enhanced FXa generation in plasma of patients with APS that is associated with the presence of anti- $\beta_{2} \mathrm{GPI}$ antibodies in these plasmas. 


\section{Patients, Materials and Methods}

Patients. Plasmas or isolated lgG fractions of six patients with antiphospholipid antibodies were used in this study. The clinical data of these patients were as follows: Patient-1" male, age 49, one arterial thrombosis and one pumonary embolism with secondary puimonary hypertension; Patient-2, male, deceased aged 70, two deep vein thrombosis, one cerebral stroke, non-Hodgkin's lymphoma; Patient-3, female, age 65, meumatoid arthritis; Patient-4, female, age 35, one deep vein thrombosis and pulmonary embolism; Patient-5, femalle, age 38, one deep vein thrombosis, two abortions; Patient 6 male, age 69, one cerebral stroke. All thromboembolic events have been objectively confirmed. None of these patients met the revised criteria (25) of the American Rheumatism Association for the diagnosis of Systemic Lupus Erythematosus. The plasmas of all patients contained IgG class anticardiolipin as determined by ELISA according to the method described by Loizou et al (26). Lupus anticoagulants were diagnosed according to the revised criteria (13) by the Subcommittee for Standardisation of Lupus Anticaagulants. In patients under oral anticoagulant treatment the Textarin/Ecarin test (Stago, Asmieres, France) was also performed, following the manufacturer's instructions (27).

Materials. Bovine serum albumin (BSA, essentially fatty acid free) was obtained from Sigma (St. Louis, MO). Protein A-Sepharose and CNBr-activated Sepharose were from Amersham Pharmacia Biotech (Uppsala, Sweden). The chromogenic substrate for thrombin (S2238) was purchased from Chromogenix (Mölndal, Sweden). 1,2-Dioleoyl-sn-glycero-3-phosphocholine (PC) and 1,2-dioleoyl-snglycero-3-phosphoserine (PS) were obtained from Avanti Polar Lipids (Alabaster, AL). Hepes buffer: $20 \mathrm{mM}$ Hepes, $0.140 \mathrm{mM} \mathrm{NaCl}, 0.5 \mathrm{mg} / \mathrm{mL}$ BSA, pH 7.5 .

Plasmas. Human normal plasma was obtained from healthy donors and stored at $-80^{\circ} \mathrm{C}$. TFPl-depleted plasma was prepared by passing normal human plasma over a column with goat anti-human TFPI antibody immobilised on Sepharose. $\mathrm{\beta}_{2} \mathrm{GPI}$ deficient plasma was prepared as follows. Rabbit anti-human $\beta_{2}$ GPI IgG was isolated by affinity chromatography using NHS-activated HiTrap column (Amersham Pharmacia Biotech, Uppsala, Sweden) to which purified human $\beta_{2}$ GPI was coupled (approx. $5 \mathrm{mg} \mathrm{mL} \mathrm{mL}^{-1}$ gel) according to the manufacturer's instructions. Subsequently, 6 mg rabbit anti-human $\beta_{2} \mathrm{GPI}$ was coupled to $\mathrm{NHS}$-activated HiTrap ( $1 \mathrm{~mL}$ column) and used to deplete $4 \mathrm{~mL}$ of human plasma from $\beta_{2} \mathrm{GPl}$ by circulating during $2 \mathrm{hrs}$.

Proteins. Recombinant full length human tissue factor (TF) was generously provided by Dr. Y. Nemerson (Mount Sinai School of Medicine, New York, NY). TF was relipidated in phospholipid vesicles containing $25 \mathrm{~mol} \% \mathrm{PS}$ and $75 \mathrm{~mol} \% \mathrm{PC}$ (TF:PSPC) as described (28) at a protein to lipid molar ratio of $1: 10^{5}$. Human $\beta_{2} \mathrm{GPI}$ (29) and human prothrombin (30) were purified and quantified as described. Recombinant full length human TFPI (rTFPl) (31) was a kind gift of Dr. T-C Wun 
(Monsanto Co, St Louis, MO). Dr. U. Hedner (Novo Nordisk, Bagsvaerd, Denmark) generously provided recombinant human FVIla. Goat anti-human TFPI antibody was a gift from Dr. O. Nordfang (Novo Nordisk, Bagsvaerd, Denmark) and was used to deplete plasma from TFPI by affinity-chromatography. Recombinant hirudin was from Ciba-Geigy (Horsham, UK)

Isolation of Antibodies. Anti-cardiolipin antibodies ( $\mathrm{aCL}$ ) were purified from the plasma of patients by adsorption to cardiolipin-containing liposomes and subsequent affinity-chromatography over a Sepharose-protein $A$ column as described previously (8). For all $\mathrm{lgG}$ preparations requirement of $\beta_{2} \mathrm{GPI}$ for the binding of these antibodies to anionic phospholipid was established by ellipsometry according to Willems et al (29). Total lgG from the plasma of patients was purified with protein A-Sepharose according to the manufacturer's instructions. Total igG was depleted of anti- $\beta_{2} \mathrm{GPI}$ IgG by passing $2-4 \mathrm{~mL}$ of the total lgG (2-10 $\left.\mathrm{mg} \mathrm{mL}^{-4}\right)$ over $2 \mathrm{~mL} \beta_{2} \mathrm{GPI}$-Sepharose gel ( $10 \mathrm{mg} \beta_{2} \mathrm{GP}$ ) coupled to $1 \mathrm{ml} \mathrm{CNBr}$-activated Sepharose gell according to the instructions of the manufacturer). After washing with Hepes-buffer ( $\mathrm{pH} 7.5)$ bound anti- $\beta_{2}$ GPI-IgG was eluted from the $\beta_{2}$ GPI-Sepharose with $0.1 \mathrm{M}$ glycine (pH 2.7), neutralised with $1 \mathrm{M}$ Tris $(\mathrm{pH}$ 9) and dialysed against Hepes-buffer $(\mathrm{pH}$ 7.5). Total IgG was depleted of anti-prothrombin-lgG by passing 2-4 mL of the total IgG (2-10 $\mathrm{mg} \mathrm{mL}^{-1}$ ) over $2 \mathrm{~mL}$ prothrombin-Sepharose gel (10 mg prothrombin coupled to $1 \mathrm{ml}$ CNBr-activated Sepharose gel according to the instructions of the manufacturer). Antibody concentration was determined using a BCA protein assay kit with BSA as a standard (Pierce, Rockford, $\mathrm{IL}$ ). Depletion (more than 95\%) of anti-prothrombin-lgG and anti- $\beta_{2} \mathrm{GPl}-\mathrm{lgG}$ from total lgG was verified using ellipsometry as described (29).

TF-Dependent Generation of FXa and Thrombin in Plasma. Citrated platelet free plasma $(135 \mu \mathrm{L}$ ) was incubated with $4 \mu \mathrm{L}$ relipidated TF (final concentrations, $15 \mathrm{pM}$ TF in $1.5 \mu \mathrm{M}$ PSPC) and $8 \mu \mathrm{L}$ Hepes buffer or other additives when indicated for 5 min at $37^{\circ} \mathrm{C}$. Coagulation was started by the addition of $3 \mu \mathrm{L}$ calcium chloride (final, total $\mathrm{Ca}^{2+} 20 \mathrm{mM}$ and free $\mathrm{Ca}^{2+} 3 \mathrm{mM}$ ). At selected time intervals, aliquots of $5 \mu \mathrm{L}$ were removed from the reaction mixture and 100-fold diluted with ice-cold Hepes buffer prior to FXa measurement or directly added to a cuvette containing $495 \mu \mathrm{L}$

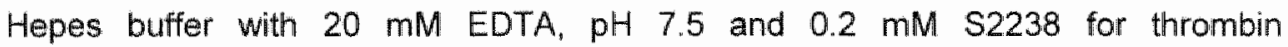
measurement. FXa was assayed as prothrombinase activity and thrombin was measured from its amidolytic activity as previously described (32).

\section{Results}

TF:FVIra-Catalyzed FX Activation in Normal and in Patient Plasma. Initial experiments were performed to compare FXa generation by TF:PSPC in normal plasma and in plasma of patient- $1,-2$ and -3 . Since patient -1 and patient- 2 were on 


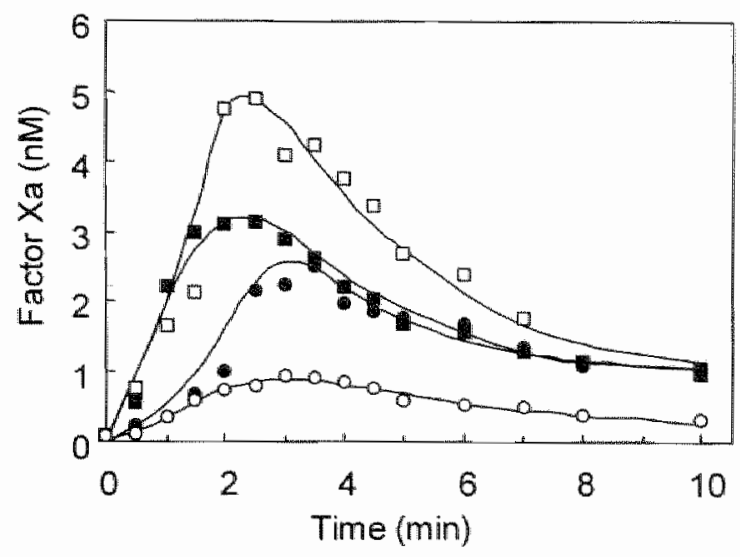

Figure 1. TF-dependent FXa generation in plasma of patients with APS. Citrated normal plasma (O). plasma from patient-1 (-), patient-2 (Q) and patient-3 (1) were recalcified with $20 \mathrm{mM} \mathrm{Ca}{ }^{2+}$ and activated with $15 \mathrm{pM}$ tissue factor embedded in $1.5 \mu \mathrm{M}$ phospholipid ( 25 mol $\%$ PS 75 mol\% PC). Patient plasmas were diluted 1.1 with normal plasma. At timed intervals an aliquot $(5 \mu \mathrm{L})$ was taken and assayed for FXa.

oral anticoagulation, all experiments with patient plasma were performed on 1:1 mixtures of patient's plasma with normal pooled plasma. Fig. 1 shows the TF:PSPC dependent FXa generation in plasma of these patients in comparison to FXa generation in normal plasma. It is evident that FXa generation in all three patient plasmas is considerably enhanced compared to normal plasma, albeit to a different extent.

In order to assure that the observed effects on FXa generation are caused by $a C L$, further experiments were performed with normal plasma supplemented with $\mathrm{aCL}$, isolated from the patient plasmas. Furthermore, to exclude that observed effects on FXa generation could be caused by alteration in intrinsic, FIXa:FVIlla mediated FXa generation, hirudin $(5 \mu \mathrm{M})$ was added to the plasma. This concentration of hirudin is sufficient to block FVIII activation in TF-activated plasma and therefore prevents any contribution of FVIlla:FIXa to the generation of FXa activity (33). Fig. 2 confirms our observations shown in Fig. 1. An enhanced FXa generation is found when normal plasma to which aCL is added is triggered with TF We note that addition of $\mathrm{aCL}\left(100 \mu \mathrm{g} \mathrm{mL}{ }^{-1}\right)$ to normal plasma does increase the peak value of $\mathrm{FXa}$ generation but not the initial rate of $\mathrm{FXa}$ generation. Factor $\mathrm{Xa}$ generation in patients plasma (Fig. 1), however, showed both increased peak values as well as increased initial rates of FXa generation. At this stage of our study we only focussed on the mechanism(s) that might be responsible for the increased FXa generation. 


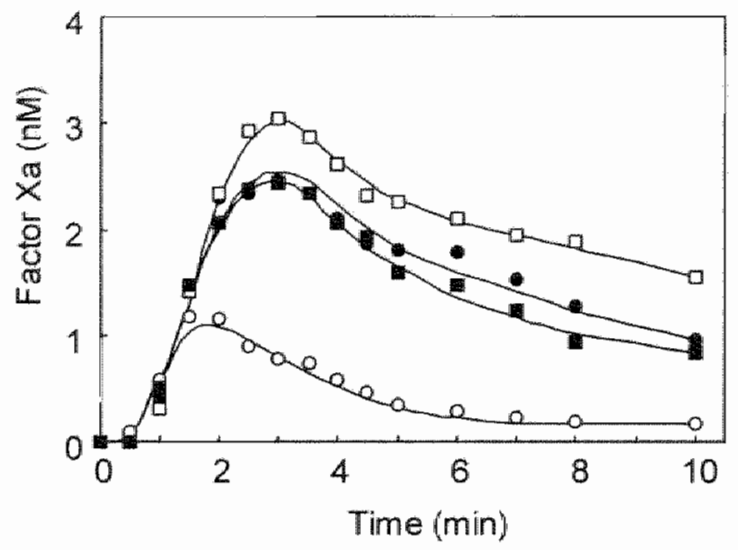

Figure 2 Effect of aCL, isolated from APS patients, on FXa generation in TFactivated normal plasma. Normal plasma was incubated with hirudin $(5 \mu M)$ in the absence of $\mathrm{aCL}(O)$ and in the presence of $0.1 \mathrm{mg} \mathrm{mL}^{-11} \mathrm{aCL}$ isolated from plasma of patient-1 (-) patient-2 (口) or patient-3 (1). Plasmas were activated as described in the legend to Fig. 1.

TFPI Dependency of aCL-Stimulated FXa Generation. As expected, a markedly increased FXa generation is observed when TFPI-depleted plasma is activated with TF (Fig. 3). The FXa peak value in TFPI-depleted plasma is about 5 -fold higher and FXa generation sustains for a much longer time than in normal plasma. It is of interest to see that the absence or presence of TFPI does not influence the initial rate of FXa generation. This is compatible with the notion that TFPI needs FXa as a 'cofactor' for its inhibitory activity (23). From Fig. 3 it is evident that aCL has no longer a stimulating effect on TF:PSPC dependent FXa generation in TFPI-deficient plasma. These data suggest that aCL reduces the inhibitory effect of TFPI on FXa generation in TF:PSPC activated plasma. Additional support for this notion was obtained from reconstitution experiments in which ITFPI was added to TFPI-depleted plasma as shown in Fig. 4. FXa generation in TF:PSPC activated TFPI depleted plasma is dramatically reduced when $5 \mathrm{nM}$ rTFPI is added (compare Fig. 4, open circles and Fig. 3, open circles). Addition of aCL appeared to reduce this inhibition by TFPI of FXa generation in a dose-dependent manner.

The Stimulatory Effect of Anti- $\beta_{2} G P I-I g G$ on TF-Dependent FXa and Thrombin Generation. We and others, previously recognized that aCL found in APS patients are not directed against negatively charged phospholipids but they recognize proteins, like $\beta_{2} \mathrm{GPI}$, prothrombin, annexin $\mathrm{V}$ and protein $\mathrm{C}$, in complex with these 


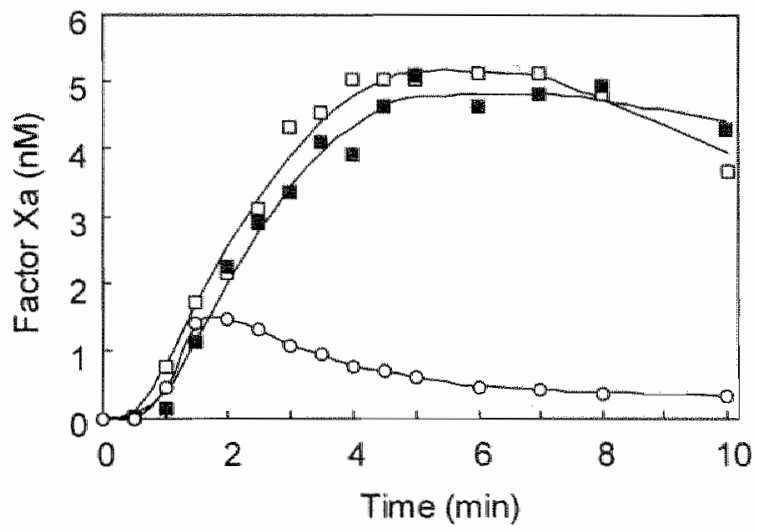

Figure 3. TFPI dependency on aCL-mediated enhancement of FXa generation in normal plasma. TFPI-depleted plasma was activated with TF:PSPC as described for Fig. 1 in the presence of $5 \mu \mathrm{M}$ hirudin, and either in the absence $(0)$ or presence (iv) of aCL (0.1 $\mathrm{mg} \mathrm{mL}^{-1}$ ) isolated from the plasma of patient- 1 . Open circles represent FXa generation in normal plasma.

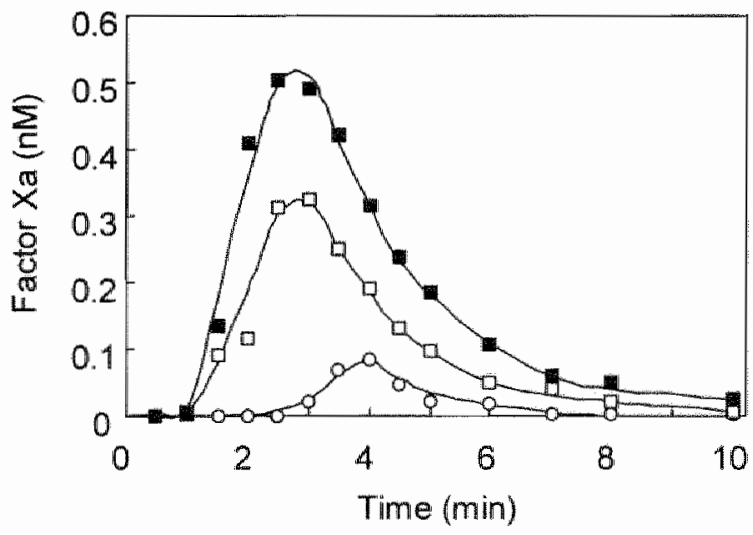

Figure 4. Effect of rTFPI and aCL on FXa generation in TF-activated plasma. TFPIdepleted plasma was reconstituted with 5 nM ITFPI and activated in the presence of hirudin ( $5 \mu \mathrm{M}$ ) with TF as described in the legend to Fig. 1 . The symbols indicate: in the

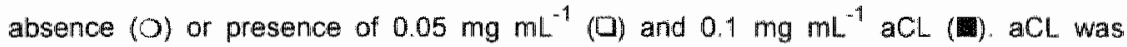
isolated from the plasma of patient-1. 
phospholipids (see ref. 34 for a review). To identify the antibody which causes the enhanced TF-induced FXa generation, we extended our study with total IgG, antiprothrombin- as well as anti- $\beta_{2}$ GPI-depleted IgG and purified anti- $\beta_{2}$ GPI-IgG isolated from the plasmas of four APS patients. In addition, in an attempt to find indications for a potential prothrombotic effect of enhanced FXa generation, we concurrently monitored thrombin generation. Therefore, in contrast to previous experiments, activation of plasma was now performed in the absence of hirudin. Fig. 5 shows the effect of anti- $\beta_{2} \mathrm{GPI}-\mathrm{igG}\left(0.1 \mathrm{mg} \mathrm{mL} \mathrm{L}^{-4}\right)$ of patient- 1 on TF-induced $F X a$ and thrombin generation in normal plasma and normal plasma that was spiked with rTFPI (5 nM). In the absence of added rTFPI the anti- $\beta_{2} \mathrm{GPI}$-lgG caused an about 2 -fold increase in FXa peak value (Fig. 5A). The thrombin generation in normal plasma appeared not to be influenced by the addition of anti- $\beta_{2}$ GPI-IgG (Fig. 5B). However, when TF-induced plasma activation was strongly inhibited by adding $\operatorname{rTFP}(5 \mathrm{nM})$, the subsequent addition of anti- $\beta_{2}$ GPI-lgG had a large stimulatory effect on both FXa (Fig. $5 \mathrm{C}$ ) and thrombin generation (Fig. 5D). Interestingly, the clotting time of rTFPI-spiked plasma was shortened from 235 to 204 seconds upon the addition of $0.1 \mathrm{mg} \mathrm{mL}^{-1}$ anti- $\beta_{2} \mathrm{GPI}$ IgG. A control experiment under similar conditions with $2 \mathrm{mg} / \mathrm{mL}$ total $\mathrm{lgG}$ isolated from normal plasma showed that this addition had no effect on either FXa or thrombin generation (data not shown). Moreover, FXa and thrombin generation were not affected by addition of anti- $\beta_{2}$ GPI-lgG $\left(0.1 \mathrm{mg} \mathrm{mL}^{-1}\right)$ to normal plasma spiked with rTFPI ( $5 \mathrm{nM}$ ) that was depleted of $\beta_{2} \mathrm{GPI}$ (data not shown).

The FXa and thrombin stimulating effects of anti- $\beta_{2} \mathrm{GPI}-\mathrm{lgG}$ preparations of other patients, expressed as fold-stimulation relative to $\mathrm{FXa}$ and thrombin peak values in normal plasma are depicted in Fig. 6 , together with those for total IgG and either anti-prothrombin- or anti- $\beta_{2} \mathrm{GPI}$-depleted IgG. It is clearly shown that both total IgG ( $\left.2 \mathrm{mg} \mathrm{mL}^{-1}\right)$ and anti- $\beta_{2} \mathrm{GPI}-\mathrm{IgG}\left(0.1 \mathrm{mg} \mathrm{mL}^{-1}\right)$ from all patients studied increased peak values of FXa (Fig. $6 \mathrm{~A}$ ) and thrombin generation (Fig. 6B), albeit to different extents. Note that anti-prothrombin-depleted IgG $\left(2 \mathrm{mg} \mathrm{mL}^{-1}\right)$ had a similar effect on both FXa and thrombin generation as total $\mathrm{lgG}$. Since the presence of antiprothrombin IgG in all total $\lg G$ preparations from these patients was confirmed by ellipsometry (see Materials and Methods), it is evident that anti-prothrombin-lgG did not enhance TF-induced FXa generation. In contrast, depletion of total IgG from anti$\beta_{2} \mathrm{GPI}-\lg \mathrm{G}$ completely abolished the effect of total IgG on both $\mathrm{FXa}$ and thrombin generation. Taken together, these data indicate that anti- $\beta_{2} G P I-\lg G$ attenuates the inhibitory effect of TFPI on TF-induced FXa generation and consequently thrombin formation. 

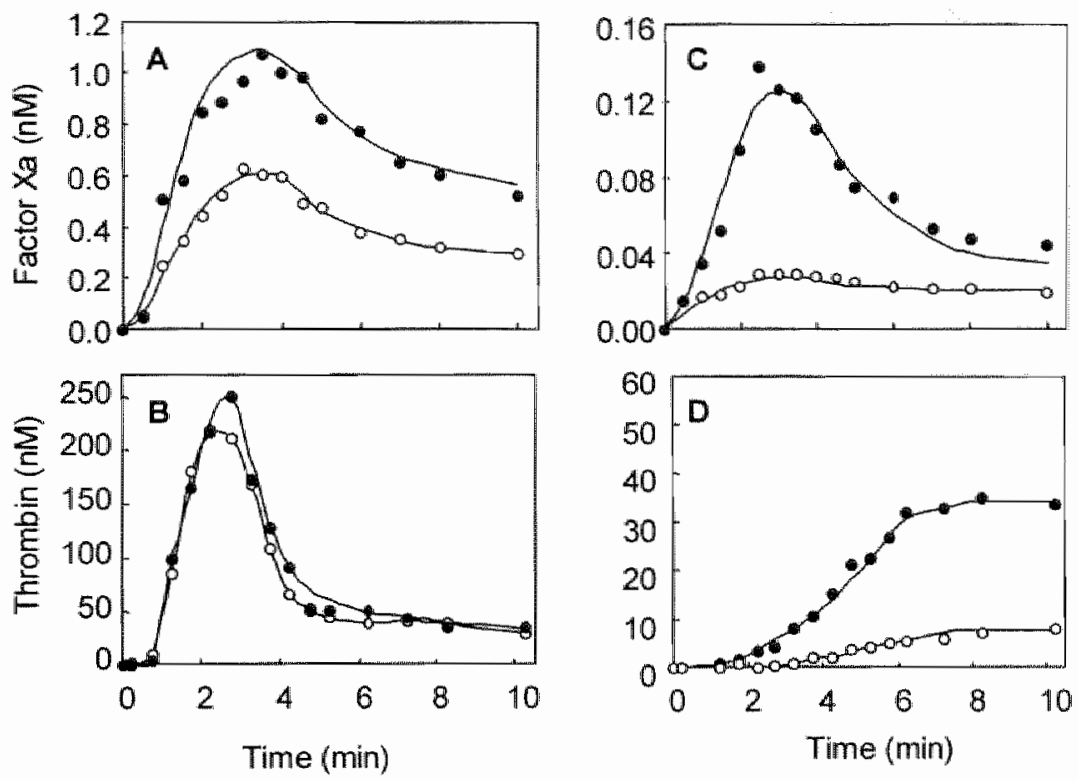

Figure 5. Effect of purified anti- $\beta_{2}$ GPI-IgG on FXa and thrombin generation in TFactivated plasma. Normal plasma without added rTFPI (panel $A$ and $B$ ) or with $5 \mathrm{nM}$ ITFPI (panel $C$ and D) was activated in the absence (O) and presence of $0.1 \mathrm{mg} \mathrm{mL}^{-1}$ purified anti- $\beta_{2}$ GPI-IgG from patient-1 (-) as clescribed in Fig. 1. Samples were removed at indicated time points and assayed for FXa (panel A and C) and thrombin (panel B and D).

\section{Discussion}

The primary goal of the present study was to investigate whether antibodies isolated from patients with APS interfere with TF-dependent FXa generation in plasma. We reasoned that, in view of a possible role of anionic phospholipids in the inhibitory reaction between FXa:TFPI complex and TF:FVIla (24) and the high affinity of the anti- $\beta_{2} \mathrm{GPI}: \beta_{2} \mathrm{GPI}$ complex for the same phospholipid binding sites (29), these antibodies may hinder the TFPI action and thus enhance FXa generation. The present finding that patient plasmas indeed show an increased FXa generation in comparison to normal plasma when activated with TF:PSPC is in line with this hypothesis. The enhanced FXa generation in TF-activated normal plasma in the 

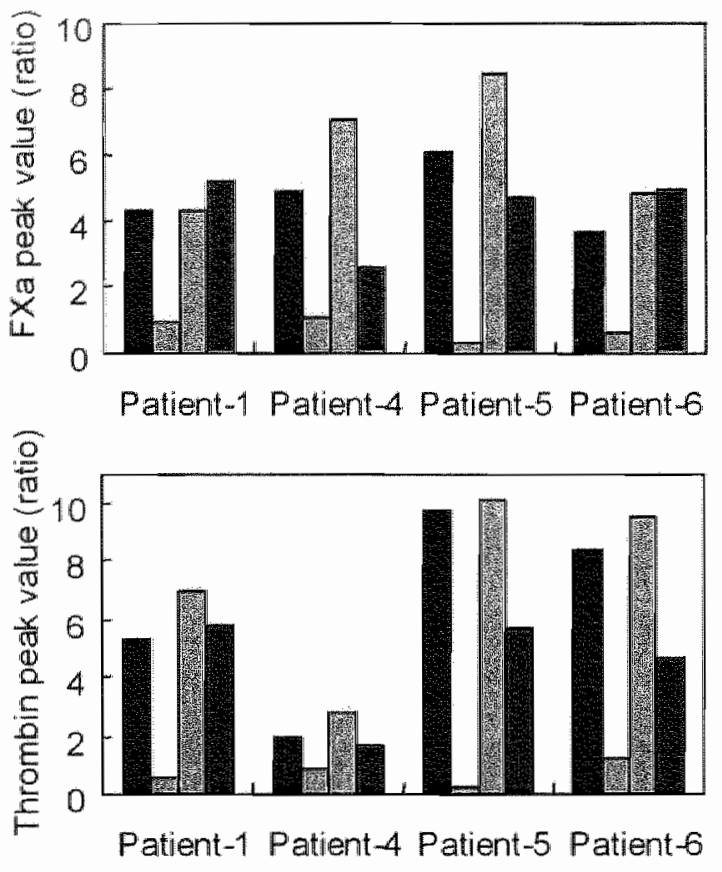

Figure 6. Stimulation of FXa and thrombin generation in TF-activated plasma by ligG fractions of APS patients. Normal plasma spiked with 5 nM ITFPI was activated with TF, as described in the legend to Fig. 1 , in the presence of $2 \mathrm{mg} \mathrm{mL}^{-1}$ total $\operatorname{lgG}()_{12}$ $\mathrm{mg} \mathrm{mL}^{-1}$ total lgG depleted of anti- $\beta_{2} \mathrm{GPI} \| \mathrm{gG}$ (圆) ; $2 \mathrm{mg} \mathrm{mL}^{-1}$ total $\mathrm{IgG}$ depleted of anti-

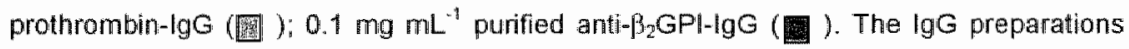
were isclated from patient plasmas as described in Material and Methods. The values are expressed as a ratio of the peak values for FXa and thrombin obtained in the presence and absence of added lgG.

presence of anti- $\beta_{2}$ GPI $-\mathrm{lg} G$ isolated from the plasma of APS patients and the absence of this effect when total IgG is depleted from anti- $\beta_{2} G P I-H g G$ but not when depleted from anti-pronrombin-IgG, clearly demonstrate that enhanced FXa generation is caused by anti- $\beta_{2} G \mathrm{GI}-\mathrm{IgG}$. We furthermore could demonstrate that increased $\mathrm{FXa}$ generation is accompanied with increased thrombin generation when normal plasma is spiked with rTFPI.

If plasma is activated with a low tissue factor concentration, in the range as used in this study, FXa generation could be sensitive to the presence of FIX and FVIII (35). It has been reported that under these conditions aCL may counterbalance 
by an as yet unknown mechanism, the inhibitory effect of $\beta_{2} \mathrm{GPI}$ on FXa generation. (16). Because this phenomenon could complicate our investigation on the effect of antiphospholipid antibodies on extrinsic FXa generation, we initially blocked the intrinsic FXa generation by adding hirudin. Previous work from our laboratory on FXa generation in plasma has indicated that in the presence of more than $1 \mu \mathrm{M}$ of recombinant hirudin, activation of FVIII and thus intrinsic FXa generation could be prevented (33).

We demonstrate that, on a weight basis, aCL preparations from three APS patients enhanced FXa generation to about the same extent in TF:PSPC-activated normal plasma containing hirudin. Further initial experiments with the $\mathrm{aCL}$ preparation of one of the patients revealed that the enhanced FXa generation in TFactivated normal plasma was dependent on the presence of TFPI. Support for this notion was obtained from experiments that showed that when the TFPI concentration in plasma was increased by the addition of recombinant full length TFPI, the stimulating effect of $\mathrm{aCL}$ on FXa generation became even more pronounced. We realise that in view of the molar concentration of anticoagulant active plasma TFPI (about $0.2-0.4 \mathrm{nM}$ ) (36), reconstitution of TFPI-depleted plasma with $5 \mathrm{nM}$ of rTFPI seems of little physiological relevance. However, it must be noticed that the question whether the plasma TFPI concentration is of physiological relevance is still not answered because the anticoagulant active TFPI is predominantly associated with the endothelium.

We recently reported that the affinity of FXa:TFPI complex for anionic phospholipids is nearly two orders of magnitude higher than the affinity of FXa for these phospholipids (37). Moreover, the complex between FXa and TFPI that lacks the phospholipid-binding site $\left(\operatorname{TFPI}_{1-161}\right)$ was found to bind with the same affinity as $\mathrm{FXa}$. Interactions of both FXa and TFPI with the phospholipid membrane are thus essential for the overall high affinity of the FXa:TFPI complex. As a matter of fact when TF:PSPC is used to activate TFPI-depleted plasma, TFPI $\|_{1-161}(10 \mathrm{nM})$ hardly inhibits plasma FXa generation (38). Taken together, these data indicate that the interaction of the FXa:TFPI complex with anionic phospholipids is critical to exert its inhibitory activity towards extrinsic FX activation. It is clear that the anti- $\beta_{2}$ GPI-igG: $\beta_{2} \mathrm{GPI}$ complex can successfully compete with the FXa:TFPI complex for the same phospholipid binding sites thereby interfering with phospholipid-dependent inhibition of FX activation, which in turn results in enhanced thrombin formation. Experiments with anti-prothrombin-lgG depleted total IgG from APS patients suggest that these antibodies are not affecting inhibition by TFPI of TF-induced FXa generation. These in vitro data may provide an interesting explanation for the prothrombotic action of anti- $\beta_{2} \mathrm{GPI}-\mathrm{IgG}$ antibodies and may contribute to better understanding of the multifactorial pathophysiology of thrombosis in patients with the antiphospholipidsyndrome. 


\section{References}

1. Hughes GRV (1983) Thrombosis, abortion, cerebral disease and the lupus anticoagulant. Br Med J $287,108 \mathrm{~g}-9$

2. Feinstein DI (1985) Lupus anticoagulant, thrombosis and fetal loss. $\mathrm{N}$ Engl $\mathrm{J}$ Med $313,1348-50$

3. Asherson RA, Harris EN (1986) Anti-cardiolipin antibodies: Clinical associations. Postgrad Med J 62, $1081-7$

4. Shapiro SS (1996) The lupus anticoagulant/antiphospholipid syndrome. Annu Rev Med 47, 53353

5. Arrout $\mathrm{J}$ (1996) The pathogenesis of the antiphospholipid syndrome: A hypothesis based an parallelisms with heparin-induced thrombocytopenia. Thromb Haemost 75, 536-41

6. Horbach DA, van Oort E, Donders RC, Derksen RH, de Groot PG (1996) Lupus anticoagulant is the strongest risk factor for both venous and arterial thrombosis in patients with systemic lupus erythematosus. Comparison between different assays for the detection of antiphospholipid antibodies: Thromb Haemost 76, 916-24

7. Lewy RA (1996) Clinical manifestations of the aPL syndrome. Lupus 5, 393-7

8. Galli $M$, Comfurius $P$, Maassen $C_{r}$ Hemker $H_{0}$, de Baets $M H$, van Breda Vriesman $P J_{4}$, Barbui T, Zwaal RF, Bevers EM (1990) Anticardiolipin antibodies (ACA) directed not to cardiolipin but to a plasma protein cofactor. Lancet 335, 1544-7

9. McNell HP, Simpson RJ, Chesterman CN, Krilis SA (1990) Antiphospholipid antibodies are directed against a complex antigen that includes a lipid binding inhibitor of coagulation: B2glycoprotein | (apolipoprotein H). Proc Natl Acad Sci USA 87, 4120-4

10. Bevers EM, Galli M, Barbuil T, P. C, Zwaal RFA (1991) Lupus anticoagulant IgG's (LA) are not directed to phospholipids only, but to a complex of lipid-bound human prothrombin. Thromb Haemost 66, 629-32

11. Roubey RAS, Pratt CW, Buyon JP, Winfield JB (1992) Lupus anticoagulant activity of autoimmune antiphospholipid antibodies is dependent upon $\beta 2$-glycoprotein I. J Clin Invest 90 , 1100-4

12. Oosting JD, Derksen RHWM, Entjes HTI, Bouma BN, De Groot PG (1992) Lupus anticoagulant activity is frequently dependent on the presence of 32 -glycoprotein I. Thromb Haemost 67, 499502 .

13. Brandt JT, Triplett DA, Alving B, Scharrer | (1995) Criteria for the diagnosis of lupus anticoagulant: An update. Thromb Haemost 74, 1185-90

14. Davie EW, Fujkawa $K_{n}$ Kisiel $W(1991)$ The coagulation cascade: Initiation, maintenance, and regulation. Biochemistry $30,10363-7$

15. Malia RG, Kitchen $S$, Greaves M, Preston FE (1990) Inhibition of activated protein $C$ and its cofactor protein $S$ by antiphospholipid antibadies. Br J Haematol $76,101.7$

16. Shi W, Chong BH, Hogg PJ, Chesterman CN (1993) Anticardiolipin antibodies inhibition by $\beta 2-$ glycoprotein I of the factor Xa generating activity of platelets. Thromb Haemost 70,342 - 


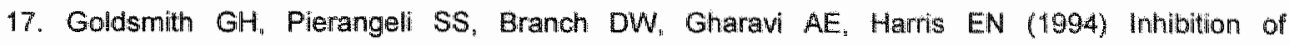
prothrombin activation by antiphospholipid antibodies and $\beta 2$-glycoprotein $1 . \mathrm{Br} \mathrm{J}$ Haematol 87 . 548-54

18. McNally T, Mackie IJ, Isenberg DA, Machin SJ (1996) B2-glycoprotein I inhibits factor XII activation on triglyceride rich lipoproteins: The effect of antibodies from plasma of patients with antiphospholipid syndrome. Thromb Haemost 76, 220-5

19. Simantov R, Lo SK, Gharavi A, Sammaritano LR, Salmon JE, Silverstein RL. (1996) Antiphospholipid antibodies activate vascular endothelial cells. Lupus 5, 440-1

20. Rand JH, Wu XX, Andree HA, Lockwood CJ, Guller S, Scher J, Harpel PC (1997) Pregnancy loss in the antiphospholipid-antibody syndrome: a possible thrombogenic mechanism. $N$ Engl $J$ Med $337,154-60$

21. Esmon NL, Smirnov MD, Esmon CT (1997) Thrombogenic mechanisms of antiphospholipid antibodies. Thromb Haemost $78,79-82$

22. Rapaport SI, Rao LVM (1995) The tissue factor pathway: How it has become a "prima ballerina". Thromb Haemost 74, 7-17

23. Broze GJ Jr (1992) The role of tissue factor pathway inhibitor in a revised coagulation cascade. Semin Hematol 29, 159-69

24. Kazama $Y$ (1997) The importance of the binding of Factor $X a$ to phospholipids in the inhibitory mechanism of tissue factor pathway inhibitor: the transmembrane and cytoplasmic domains of tissue factor are not essential for the inhibitory action of tissue factor pathway inhibitor. Thromb Haemost 77, 492-7

25. Tan EM, Cohen AS, Fries JF, Masi AT, McShane DJ, Rothfield NF, Schaller JG,Talal N, Winchester RJ (1982) The 1982 revised criteria for the classification of systemic lupus erythematosus. Arthritis Rheum 25, 1271-7

26. Loizou S, McCrea JD, Rudge AC, Reynolds R, Boyle CC, Harris EN (1985) Measurement of anticardiolipin antibodies by an enzyme-linked immunosorbent assay (ELISA): standardization and quantitation of results. Clin Exp Immunol 62, 738-44

27. Triplett DA, Stocker KF. Unger GA, Barna LK (1993) The textarin/Ecarin ratio: a confirmatory test for lupus anticoagulant. Thromb Haemost $70,925-31$

28. Bach $R$, Gentry $R_{n}$ Nemerson $Y(1986)$ Factor VII binding to tissue factor in reconistituted phospholipid vesicles: Induction of co-operativity by phosphatidyl-serine. Biochemistry 25, 4007. 20

29. Willems GM, Janssen MP. Pelsers MM, Comfurius $P$, Galli M, Zwaal RFA, Bevers EM (1996) Role of divalency in the high-affinity binding of anticardiolipin antibody-132-glycoprotein complexes to lipid membranes. Biochemistry $35,13833-42$

30. DiScipio RG, Hermodson MA, Yates SG, Davie EW (1977) A comparison of human prothrombin. factor IX (Christmas factor), factor X (Stuart factor), and protein S. Biochemistry 16,698-706

31. Diaz-Collier JA, Palmier MO, Kretzmer KK, Bishop BF, Combs RG, Obukowicz MG, Frazier RB, Bild GS, Joy WD, Hill SR, Duffin KL, Gustafson ME, Juriger KD, Grabner RW, Galluppi GR, Wun 
TC (1994) Refold and characterization of recombinant tissue factor pathway inhibitor expressed in Escherichili coli. Thromb Haemost $71,339-46$

32. Pieters $J_{1}$ Lindhout $T(1988)$ The limited importance of factor $X a$ inhibition to the anticoagulant property of heparin in thromboplastin-activated plasma. Blood $72,2048-52$

33. Pieters $J$. Lindhout $T$. Hemker $H C$ (1989) In situ generated thrombin is the onlly enzyme that effectively activates factor VIII and Factor $V$ in thromboplastin-activated plasma. Blood $74,1021-4$

34. Rauchi $\mathrm{J}(1998)$ Lupus anticoagulant antibodies: recognition of phospholipid-binding protein complex. Lupus 7:529-31

35. Dsterud B, Rapaport SI ("1977) Activation of factor IX by the reaction product of tissue factor and factor VIl: additional pathway for initiating blood coagulation. Proc Natl Acad Sci USA 74,5260-4

36. Hansen JB, Huseby KR. Huseby NE, Ezban M, Nordoy A (1997) Tissue factor pathway inhibitor in complex with low density lipoprotein isolated from human plasma does not possess anticoagulant function in tissue factor induced coagulation in vitro. Thromb Res 85, 413-25

37. Willems GM, Janssen MP, Salemink I, Wun TC, Lindhout $T$ (1998) Transient high affinity binding of tissue factor pathway inhibitor-factor $\mathrm{Xa}$ complexes to negatively charged phospholipid membranes. Blochemistry 37, 3321-8

38. Salemink I, Franssen J, Willems GM, Hemker HC, Li AG, Wun TC, Lindhout T (1998) Factor Xa cleavage of tissule factor pathway inhibitor is associated with loss of anticoagulant activity. Thromb Haemost $80,273-80$ 


\title{
Chapter 7
}

\author{
Summarizing Discussion
}

In 1905 Morawitz $(1,2)$ recognized the involvement of tissue factor (TF) in coagulation and in the past years the prominent role of the TF pathway in various pathophysiological conditions became clear. An example is Trousseau syndrome, in which repeated thromboembolic episodes occur due to the continuous exposure of TF present in tumour cells to circulating blood (3-6). Also fatal coronary ischemic events that were related to plasma levels of activated factor $V I I(7,8)$ have been described. Rightly, Rapaport and Rao (9) assigned the TF-pathway the role of "Prima Ballerina". Actually, the recent discovery that the TF content of atherosclerotic plaques seems to predict plaque thrombogenecity $(10,11)$, the discovery of blood borne TF (12), the possible involvement of TF in angiogenesis (13-15) and blood vessel development (16-19), places TF in the spotlight.

These conceptual advances make it essential to understand the structural basis of TF function and its regulation by tissue factor pathway inhibitor (TFPI), the specific inhibitor of the TF-dependent pathway. This may result in a better insight into the potential strategies for designing inhibitor molecules to prevent and treat TF-mediated thrombogenesis. 
Previous research $(20-23)$ indicated that the positively charged C-terminus of TFPI likely plays an important role in the inhibitory action towards TF:FVIlacatalyzed FX activation. In addition, the TFPI C-terminus was shown to be critically involved in binding of TFPI to anionic phospholipids (24) that also appeared to contribute to the inhibitory action of full length TFPI (TFP $\|_{F L}$ ). This was not the case for C-terminally truncated TFPI (TFPl $1-161)(20,25)$. From these findings, it was hypothesized that the interaction of the TFPI C-terminus with anionic phospholipid membranes plays a role in the kinetics of TF:FVlla inhibition.

Accordingly, we have focussed our studies on the influence of anionic phospholipids on the inhibition of TF:FVlla mediated FXa generation by FXa:TFPIFL and FXa: TFPI $\left.\right|_{\uparrow_{16}}$. Only qualitative data were available regarding the interaction of TFPI and FXa:TFPI with phospholipid membranes (24). Therefore, we started with a quantitative study of binding of FXa, TFPI and FXa:TFPI to phospholipids by using ellipsometry. As outlined in chapter 2, we demonstrated that complexes of FXa:TFPI FL bind with high affinity $\left(K_{d}=5.5 \mathrm{nM}\right)$ to planar phospholipid surfaces consisting of 25 mol\% phosphatidylserine and 75 mol\% phosphatidylcholine (PSPC). FXa:TFPI 1-161 complexes on the other hand, bind to this surface with a much lower affinity that in fact does not differ from the affinity of FXa alone ( $K_{d}=42$ $\mathrm{nM}$ ). This increased affinity thus requires the presence of the third Kunitz domain and the positively charged C-terminus. Remarkably, TFPIFL itself shows a negligible small binding to PSPC $\left(K_{d}>5 \mu M\right)$ whereas it drastically enhances, when in complex, the phosphollipid binding of FXa. Valentin et all (24) noticed that divalent cations could prevent the binding of TFPI FL to phospholipid membranes. We, on the other hand, have shown that the FXa:TFPI $\mathrm{FL}$ complex strictly depends on the presence of $\mathrm{Ca}^{2+}$ for its binding to PSPC. Depletion of $\mathrm{Ca}^{2 *}$ by the addition of EDTA caused an immediate desorption of FXa:TFPI FL. These combined observations indicate that FXa, probably via its Gla-domain, binds to PSPC in a $\mathrm{Ca}^{2+}$ dependent manner, whereas the TFPI C-terminus interacts electrostatically ( $\mathrm{Ca}^{2 *}$ independent) with the negative charges in the phospholipid membrane. When the maximal binding $\left(\Gamma_{\max }\right.$ ) is expressed as molecules per unit area, $\Gamma_{\max }$ is lower for $F X_{\text {a:TFPl }}$. $\left(4.7 \mathrm{pmol} \mathrm{cm}^{-2}\right)$ than for FXa alone $\left(\Gamma_{\text {max }}=8.1 \mathrm{pmol} \mathrm{cm}^{-2}\right)$. This means that the footprint at the membrane (i.e. the surface occupation) is increased for FXa:TFPIFL compared to FXa, supporting the notion that both FXa and TFPI in the FXa:TFPI complex interact with the phospholipid surface. Petersen et al (26) reported that regions, other than the contact area of the second Kunitz domain, interact strongly with FXa. These secondary-site interactions, occurring after binding of FXa to TFPI, then may induce a conformational restraint that optimally aligns the TFP\|Cterminus for interaction with anionic lipid, stupporting FXa:TFPIFL binding to PSPC. Another line of evidence for the importance of the C-terminus of TFP/FL and its orientation is the transient high binding affinity that we observed. FXa:TFPI 
complexes were shown to slowly desorb from PS containing surfaces when FXa was present in excess over TFPI. Closer investigation of this phenomenon revealed that FXa cleaved TFPI between residues Arg ${ }^{199}-$ Ala $^{200}$ within the third Kunitz domain of TFPI. The presence of three disulfide bridges in this domain prevents the dissociation of the C-terminal part from the TFPI molecule. However, since this

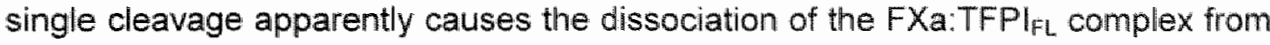
the phospholipid surface, we hypothesized that the C-terminus probably reorientates after cleavage and is withdrawn from the PSPC surface. As a consequence the FXa:TFPI complex looses its high binding affinity interaction with the phospholipid membrane.

Further examination (chapter 3) of the FXa mediated limited proteolysis of TFPI revealed that cleavage of the $\mathrm{Arg}^{199}-\mathrm{Ala}^{200}$ bond dramatically reduced the anticoagulant activity of TFPI in plasma, in a dilute TF assay. In contrast, this cleavage at $\mathrm{Arg}^{199}-\mathrm{Ala}^{200}$ appeared not to have an effect on the inhibitory activity of TFPI towards TF:FVIla catalyzed FX activation as measured in a purified system. These data suggest that apparently the dilute TF test as we have used is more sensitive to differences in lipid binding of FXa:TFPI preparations than the purified system. Presently, this difference between plasma and purified system remains unexplained. It should however be noted that in the plasma test, initiation (FVII and FX activation), prolongation (FV, FVIII and FIX activation, prothrombinase assembly) and inhibition (by TFPI and ATIII) are all involved and in addition may compete for the same phospholipid binding sites. Any shift in one of these interactions may be readily observed in this assay.

In addition to FXa mediated cleavage at the Arg $^{199}-$ Lys $^{200}$ site of TFPI, we identified a second site in TFPI, at $L y s^{86}-T_{h r}{ }^{87}$ "that is susceptible to cleavage by FXa. As judged from the time course of appearance of the proteolytic fragment it followed that this cleavage either took place after the Arg ${ }^{199}-$ Ala ${ }^{200}$ cleavage or at the same time but with a much slower rate. In this respect it is interesting to note that when PS was omitted from the vesicles that were used, cleavage of TFPI was much slower and the first cleavage to be observed was at $\mathrm{Arg}^{190}$. $\mathrm{Ala}^{200}$. The effect of Lys ${ }^{86}-$ Thr $^{87}$ cleavage on the inhibitory activity of TFPI was sensed in both the dilute TF-assay and in the purified system. This is easily understood, as proteolysis of the Lys ${ }^{86}-$ Thr $^{87}$ bond cleaves the first Kunitz domain from the TFPI molecule, thereby dissociating the FXa binding region from the FWla binding region. As has been previously reported $(27,28)$ this results in the complete abrogation of TFPI anticoagulant activity.

Whether the cleavages reported in chapter 3 would occur in vivo remains to be established. An elegant way of accomplishing this will be to clot plasma with thromboplastin and determine to what extent plasma TFPI becomes cleaved. The objection to this approach is, however, that the plasma TFPI concentration is rather 
low and that the majority of this TFPl is already truncated at residue 177 (29), which preciudes the identification of the $\mathrm{Arg}^{199}-\mathrm{Ala}^{200}$ cleavage in a more physiological environment. Since TFPI released by heparin in wivo has a molecular weight of $43 \mathrm{kDa}(30,31)$, resembling TFPIFL, an acceptable alternative approach would be the addition of recombinant TFPI to plasma and study the FXa mediated proteolysis of this TFPI. In this respect we have shown that FXa:TFPlFL not only resides at artificial PSPC surfaces (chapter 2 and 4 ) but also at PS exposing fibroblasts (chapter 5). Because activated platelets present in the haemostatic plug also expose PS at their outer membrane surface, they may provide the surface in Vivo, for FXa and FXa:TFPI FL binding and promote the cleavage of TFPI by FXa. This proteolysis of TFPI could provide a novel degradation pathway in addition to degradation by fibrin bound thrombin (32).

The indirect evidence (chapter 3 ) that phospholipid binding could be important for the inhibitory activity of FXa:TFPIFL was further investigated in a well defined flow system as described in chapter 4. We showed that at a neutral phospholipid surface with embedded TF (TF:PC), preformed complexes of FXa:TFPI $F_{F L}$ and FXa:TFPI ${ }_{1-161}$ had similar rate constants of inhibition for inactivation of TF:FVIla activity. This was not surprising since $\mathrm{FXa}$, nor TFPI $\mathrm{FL}_{\text {or }} \mathrm{TFPI}_{1-161}$ has an interaction with this surface $(24,33)$. Our data show that inhibition of TF:FVIla by FXa:TFPI does not require the presence of anionic phospholipids in contrast to the claim of Kazama (34) that binding of FXa to phospholipids through its Gla domain is essential for the inhibitory mechanism of TFPI. This claim was based on experiments conducted with TF lacking the transmembrane and cytoplasmic domain (TF $1-219)$. In these experiments $T_{1-219}$. FVlla activity was inhibited by $F X_{a}: T F P I_{F L}$ only when anionic phospholipids were present. Because TF $1-219$ binds FVlla with the same affinity as TF in PC vesicles $(35-40)$ it seems unlikely that a decreased binding of FVlla explains the difference in observations made by Kazama and by us. Presumably the membrane, regardless whether it contains. PS, supports and/or stabilizes a particular TF:FVIla structure that plays a role in the FXa:TFPI mediated inhibition of TF:FVIla. In this respect it is worthwhile to mention that Higashi et al (41) suggested that truncation of the membrane and cytoplasmic domains of TF destabilizes the structure of the C-terminal module of $T F_{1-219}$ thereby leading to the loss of interaction with the Gla-domain of FVlla. This, in turn, may affect the inhibition of TF:FVlla by FXa:TFPI.

Remarkably, the presence of PS in the membrane stimulated the inhibitory activity of complex with the lowest affinity for PSPC (FXa:TFPI ${ }_{1.161}$ ) to a greater extent than the complex with the highest affinity i.e. FXa:TFPI FL (chapter 4). Although less likely, this could point at an intrinsic difference between FXa:TFPIFL and $F X a: T_{F P I_{1-161}}$. We speculated that due to the high affinity binding of FXa:TFPI $\left.\right|_{F L}$ to PSPC the solution near the surface was depleted from inhibitor complex resulting 
in an apparent lower inhibitory activity. This membrane bound FXa:TFPI $F$ was however not lost for its inhibitory activity, as shown from experiments in which the inhibitory activity of specifically this membrane bound FXa:TFPI FL was assessed. A TF:PSPC surface was pre-incubated with FXa:TFPIFL in the absence of FVIla and after depleting the reaction solution from inhibitor "FXa generation was started by the addition of FVIla and FX. It was clearly demonstrated that whether or not the inhibitor was depleted from the reaction solution after pre-incubation, in both situations the same, strongly inhibited FXa generation was observed. Remarkably, when the experiment was performed without pre-incubation, that is FXa:TFPlFL was added concomitantly with FX to the reaction solution, a much less effective inhibition of TF:FVIla was observed. These observations indicated that within the 10 min of pre-incubation a significant amount of FXa:TFPl FL. had adsorbed to the phospholipid surface and consequently determined the overall rate of inthibition because of the identical FXa generation after depleting the inhibitor from solution and when it was still present in the reaction solution. Another aspect of the FXa generation curves obtained after pre-incubation of TF:PSPC with FXa:TFPIFL is that they show a biphasic progress. After a very fast inhibition of the initial velocity of FXa generation ( $\left.V_{0}\right)$, the remaining TF:FVIla activity is inhibited but at a slower rate. The rate constants of inhibition $(k)$ of TF:FVIla by FXa:TFPI were estimated by fitting equation 3 , describing a mono-exponential decay of TF:FVIla activity, to the data (chapter 4). The values of $k=0.15 \mathrm{~min}^{-1}$ (inhibitor not depleted) and $k=0.13$ min $^{-1}$ (inhibitor depleted) seem rather low compared to the rate constant of inhibition of $0.42 \mathrm{~min}^{-1}$ obtained when FXa:TFPI $F L$ was added together with $F X$ to the reaction sollution. The reason for this disparity is presently unknown. Thus although it is not reflected by the rate constants of inhibition, phospholipid bound FXa:TFPIFL could have a great inhibitory potential, probably greater then is recognized when studying FXa:TFP\| $\|_{F L}$ in solution.

The origin of the fast inhibition of the initial velocity of FX activation is presently uncertain. Because we have not observed any inhibition of TF.FVlla activity when FXa:TFPl $F$ was pre-incubated with TF:PC, followed by depletion of FXa:TFPlFa from the solution, it seems unlikely that FXa:TFP|FL interacts directly with TF under the conditions of the experiment. Our suggestion is that FXa:TFPlFL bound in close proximity of TF is rapidly drawn into the quaternary complex as soon as FVIla has been added.

The observation that the residence of FXa:TFPlFL not only occurred at TF:PSPC surfaces but also at fibroblasts exposing PS at their outer membrane surface (chapter 5), might point at a physiologically relevant property of TFPI. That is, FXa:TFPl FL bound to a cell surface may be very effective in controlling the TF pathway when "new" TF arrives at the plasma membrane of a cell. This "new" TF may be generated by mechanisms like transcriptional regulation of TF gene 
expression and by cell membrane alterations in cells expressing TF, particularly by increasing the PS content of the outer cell surface membrane (42-44). Known stimuli in wivo, which can regulate the expression of cell surface TF activity by the latter mechanism are thrombin and also bradikinin and histamine liberated in inflammatory reactions (42). Interesting to note is that TF containing cells undergoing apoptosis also exhibit increased expression of PS and an increased TF functional activity $(45,46)$. An efficient inhibition by cell surface bound FXa:TFPIFL could provide an important regulatory mechanism.

The data described in this thesis support the notion that anionic phospholipids have a dual role in blood coagulation since both amplification and termination reactions of the blood coagulation process are greatly enhanced by their presence (47). For the TF-pathway this implies that anionic phospholipids stimulate the procoagulant TF:FVIla activity but also the anti-coagulant activity of FXa:TFPI, as visualized schematically in Fig. 1.
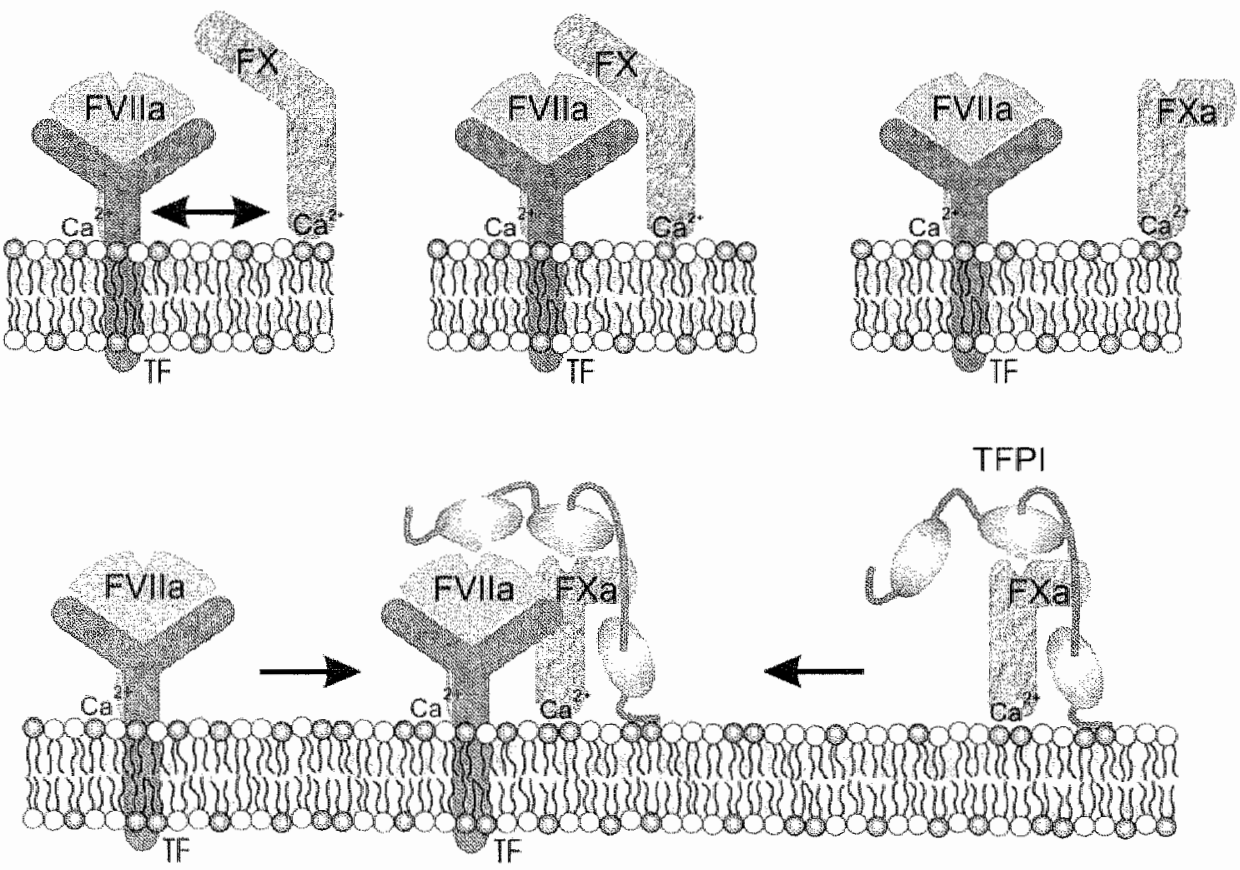

Figure 1 . Schematic representation of the pro- and anticoagulant action of anionic phospholipids in the TF-dependent pathway. Both FX activation by TF (procoagulant) and FXa:TFPI inhibitory activity (anticoagulant) are promoted by anionic phospholipids: 
This notion also implies that components with a high affinity for anionic phospholipids may compete with blood coagulation proteins for the same membrane-binding sites, and could consequently interfere with both pro- and anticoagulant reactions. The net result of this interference may then result in either stimulation or suppression of blood coagulation. A pathophysiological condition in which this aforementioned scenario may operate is the antiphospholipid or Hughes' syndrome. Patients with this syndrome carry antibodies directed against phospholipid binding plasma proteins and the resultant antibody-antigen complexes could compete for phospholipid binding sites. Whereas the in vitro coagulation tests (aPTT, dRWT) for the plasmas of these patients are often prolonged, in vivo these patients suffer from various thrombotic complications.

We hypothesized that antiphospholipid antibodies potentially interfere with the inhibitory activity of FXa:TFPI on TF:FVlla catalyzed FX activation, which would consequently result in an increased $\mathrm{FXa}$ generation. Indeed, as demonstrated (chapter 6), TF:FVlla catalyzed FX activation in plasma from patients with Hughes' syndrome was increased compared to normal plasma. The addition of total-IgG, isolated from the patient's plasma, to normal plasma also stimulated the TF-induced FXa generation. Furthermore it was established that this observed increase in FXa generation was dependent on the presence of TFPI and anionic phospholipids. Depletion of patient's total IgG from anti $\beta_{2}$-glycoprotein I IgG (anti $\beta_{2}$-GPI) resulted in a complete loss of the stimulatory effect on FXa generation. In normal plasma, depleted from $\beta_{2}-G P I$, we found no effect of anti $\beta_{2}-G P I$ IgG. Conclus ive experiments with purified anti $\beta_{2}$-GPI lgG added to normal plasma proved that this was the antibody present in patients with Hughes' syndrome responsible for the observed enhancement of FXa generation after stimulation with TF. This increased FXa generation in normal plasma observed upon the addition of anti $\beta_{2}$-GPI was not accompanied by an increased thrombin generation. However, when normal plasma was spiked with TFPI $(5 \mathrm{nM})$, the FXa- and thrombin generation were strongly reduced compared to normal plasma (approx. 20 fold). In this situation, subsequent addition of anti $\beta_{2}$-GPI resulted in an $\sim 5$-fold stimulation of both $F X a$ and thrombin generation in this TFPI spiked plasma. These data indicate that anti $\mathrm{B}_{2}-\mathrm{GPI}$ antibodies in patients with Hughes' syndrome diminish the inhibitory activity of TFPI towards TF-induced coagulation. As a consequence, an increased $F X a$ and thrombin generation may result.

The amount of recombinant TFPI added in the experiments seems rather high ( $5 \mathrm{nM}$ ) compared to the concentration of anticoagulant active plasma TFPI: $0.2 \mathrm{nM}$ (48). On the other hand, a large pool of TFPI is associated with the endothelium. This could mean that high local concentrations of TFPI may be present at the site of coagulation. 
In explaining the in vivo procoagulant action of antiphospholipid antibodies the emphasis has until now mainly been on the inhibition of the protein $C$ pathway (49, 50). The possible effect of anti-phospholipid antibodies on TFPI inhibitory function as described here could point at a completely new mechanism possibly explaining the thrombotic complications in Hughes' syndrome. Musial et al (51) observed that thrombin generation measured ex vivo following microvascular injury was increased in patients having anti-phospholipid antibodies. Because in the same patients the generation of thrombin in plasma in vitro was delayed, Musial and colleagues pointed at the endothelium to play an important role. As discussed earlier, the endothelium is likely to be the largest source of releasable TFPI. It thus is possible that the results found by Musial et al could be explained by an impaired TFPI inhibitory activity. Recent studies link anti-phospholipid antibodies to an increased pro-coagulant activity of monocytes $(52-54)$ and endothelial cells $(55,56)$ due to an increased TF expression. If this increased TF expression is accompanied by an increased TF:FVlla activity then it is easy to envision that an additional impaired TFPI-dependent inhibition of TF-induced coagulation, caused by antiphospholipid antibodies, could have dramatic consequences for $\mathrm{FXa}$ and thrombin generation.

In summary, our results provide additional evidence for the importance of the TFPI C-terminus in the inhibition of TF:FVlla in a plasma environment, and in the high affinity binding of FXa:TFPl $F \mathrm{~F}$ to anionic phospholipid membranes. FXa mediated proteolytic cleavage of the $\mathrm{Arg}^{199}-\mathrm{Ala}^{200}$ bond located in the third Kunitz domain of TFPI results in a decrease of membrane binding affinity and in addition causes a dramatic reduction of the TFPI anticoagulant activity. It appears that the interaction of both FXa and TFP $\mid$ with anionic phospholipids stimulates the inhibitory activity of FXa:TFPI towards TF:FVlla catalyzed FX activation. Although the presence of anionic phospholipids and/or the TFPI C-terminus causes a marked difference in inhibitory activity between FXa:TFPIFL and FXa:TFPI ${ }_{1-161}$, both are not an absolute requirement for an effective inhibition of TF:FVlla. An interesting consequence of the much higher affinity of FXa:TFPI $F \mathrm{~F}$ is that this allows the FXa:TFPIFL. complex to reside at anionic phospholipid surfaces and fibroblasts membranes exposing PS in their outer membrane leaflet. The physiological rellevance may be that this feature facilitates $F X_{a}: T F P I_{F L}$ to effectively control newly formed catalytic units at the plasma membrane of (apoptotic) TF producing cells. Interference with the phospholipid interaction of FXa:TFPlFL, as observed for anti $\beta_{2}$ GPI antibodies present in Hughes' syndrome, could dramatically impair its inhibitory action and result in increased $\mathrm{FXa}$ and thrombin generation. 


\section{References}

1. Morawitz P (1905) Die chemie der Blutgerinnung. Ergeb Physiol 4, 307-14.

2. Morawitz. P. (Translated by Hartmann RCaG, P.F.) The chemistry of blood coagulation. in: Thomas CC, eds. Springfield MA: 1958: 194.

3. Sack GH, Jr., Levin J and Bell WR (1977) Trousseau's syndrome and other manifestations of chronic disseminated coagulopathy in patients with neoplasms: Clinical, pathophysiologic, and therapeutic features. Medicine (Baltimore) $56,1-37$.

4. Callander NS, Varki N and Rao LVM (1992) Immunohistochemical identification of tissue factor in solid fumors. Cancer $70,1194-201$.

5. Callander N and Rapaport SI (1993) Trousseau's syndrome. West J Med 158, 364 71.

6. Rao LVM (1992) Tissue factor as a tumor procoaglulant. Cancer Metastasis Rev 11, 249. 66.

7. Meade TW" Ruddock V, Stirling Y, Chakrabarti R and Miller GJ (1993) Fibrinolytic activity, clotting factors, and long-term incidence of ischaemic heart disease in the Northwick Park Heart Study. Lancet 342, 1076-9.

8. Heinrich J, Balleisen $L$, Schulte $H$, Assmann $G$ and van de Loo J (1994) Fibrinogen and factor VII in the prediction of coronary risk. Results from the PROCAM study in healthy men. Arterioscler Thromb 14, 54-9.

9. Rapaport SI and Rao LVM (1995) The tissue factor pathway: How it has become a "prima ballerina". Thromb Haemost $74,7-17$.

10. Toschi $V$, Gallo $R$, Lettino $M$, Fallon JT, Gertz SD, Fernandezortiz A, Chesebro JH, Badimon L, Nemerson Y, Fuster $V$ and Badimon JJ (1997) Tissue Factor modulates the thrombogenicity of human atherasclerotic plaques. Circulation 95, 594-9.

11. Badimon $J J_{\text {, Lettino } M}$, Toschi $V$, Fuster $V$, Berrozpe $M$, Chesebro $J H$ and Badimon $L$ (1999) Local inhibition of tissue factor reduces the thrombogenicity of disrupted human atherosclerotic plaques: Effects of tissue factor pathway inhibitor on plaque thrombogenicity under flow conditions. Circulation 99, 1780-7.

12. Giesen $P L_{n}$ Rauch U. Bohrmann B, Kling D, Roque M. Fallon JT, Badimon $J J_{u}$ Himber $J$, Riederer MA and Nemerson Y (1999) Blood-bome tissue factor: Another view of thrombosis. Proc Natl Acad Scl USA 96, 2311-5.

13. Zhang $Y$, Deng $Y$, Luther $T$, Muller $M$, Ziegler $R$, Waldherr $R$, Stern DM and Nawroth PP (1994) Tissue factor controls the balance of angiogenic and antiangiogenic properties of tumor cells in mice. J Clin linvest 94, 1320-7.

14. Bromberg ME, Konigsberg WH. Madison JF, Pawashe A, and Garen A (1995) Tlissue factor promotes melanoma metastasis by a pathway independent of blood coagulation. Proc Natl Acad Sci USA 92, 8205-9.

15. Contrino $J_{*}$ Hair $G$, Kreutzer $D L$ and Rickles FR (1996) In situ detection of tissue factor in vascular endothelial cells: Correlation with the malignant phenotype of human breast disease. Nature Medicine 2, 209-15. 
16. Bugge TH, Xiao Q. Kombrinck. KW, Flick M॥, Holmback K, Danton MJ, Colbert MC, Witte DP. Fujkawa $K$, Davie EW and Deglen JL. (1996) Fatal embryonic bleeding events in mice lacking tissue factor, the cell- associated initiator of blood coagulation. Proc Nath Acad Sci USA $93,6258-63$.

17. Carmeliet $P$, Mackman $N$, Moons $L$, Luther $T$, Gressens $P$, Vanvlaenderen $I$, Demunck $H$, Kasper $M_{1}$ Breler $G_{\text {i }}$ Evrard $P_{1}$ Muller $M_{*}$ Risau $W_{1}$ Edgington T and Collen D (1996) Role of tissue factor in embryonic blood vessel development. Nature 383, 73-5.

18. Toomey JR, Kratzer KE, Lasky NM, Stanton JJ and Broze GJ Jr (1996) Targeted disruption of the murine tissue factor gene results in embryonic lethality. Blood 88, 15:83-7.

19. Toomey JR, Kratzer KE, Lasky NM and Broze GJ Jr (1997) Effect of tissue factor deficiency on mouse and tumor development. Proc Nati Acad Sci USA 94, 6922-6.

20. Huang ZF, Wun TC and Broze GJ Jr (1993) Kinetics of Factor-Xa inhibition by tissue factor pathway inhibitor. $J$ Biol Chem $268,26950-5$

21. Lindhout $T$, Willems $G$, Blezer R and Hemker HC (1994) Kinetics of the inthibition of human factor $\mathrm{Xa}$ by full-wength and truncated recombinant tissue factor pathway inhibitor. Biochem J 297, 131-6.

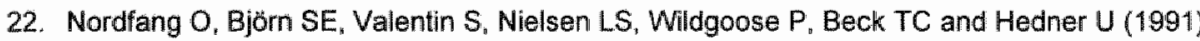
The C-terminus of tissue factor pathway inhibitor is essential to its anticoagulant activity. Biochemistry $30,10371-6$.

23. Wesselschmidt R, Likert K, Girard T. Wun TC and Broze GJ Jr (1992) Tissue factor pathway inhibitor: The carboxy-terminus is required for optimal inhibition of factor Xa. Bload $79,2004-10$.

24. Valentir $S$ and Schousboe I (1996) Factor $X a$ enhances the binding of tissue factor pathway inhibitor to acidic phospholipids. Thromb Haemost $75,796-800$.

25. Lindhout $T$, Franssen $J$ and Willems $G$ (1995) Kinetics of the inhibition of tissue factorfactor Vlla by tissue factor pathway inhibitor. Thromb Haemost $74,910-5$.

26. Petersen LC, Björn SE, Olsen $O H$, Nordfang $O$. Norris $F$ and Norris $K$ (1996) Inhibitory properties of separate recombinant Kunitz-type-protease-inhibitor domains from tissuefactor-pathway inhibitor. Eur J Biochem 235, 390-6.

27. Higuchi DA, Wun TC, Likert KM and Broze GJ Jr (1992) The effect of leukocyte elastase on tissue factor pathway inhibitor. Blood 79, 1712-9.

28. Petersen LC, Bjorn SE and Nordfang O (1992) Effect of leukocyte proteinases on tissue factor pathway inhibitor. Thromb Haemost 67, 537-41.

29. Broze GJ Jr, Lange GW, Duffin $K L$ and Mac.Phail L (1994) Heterogeneity of plasma tissue factor pathway inhibitor. Blood Coag Fibrinol 5, 551.9.

30. Wun TC, Huang MD, Kretzmer KK, Palmier MO, Day KC, Bulock JW, Fok KF and Broze GJ Jr (1990) Immunoaffinity purification and characterization of lipoprotein-associated coagulation inhibitors from Hep G2 hepatoma, Chang liver, and SK hepatoma cells. A comparative study. J Biol Chem 265 "16096-101.

31. Novotny WF, Palmier M. Wun T-C. Broze $G\rfloor J r$ and Miletich JP (1991) Purification and 
properties of heparin-releasable lipoprotein-associated coagulation inhibitor. Blood 78,394 400.

32. Ohkura N, Enjyoji $\mathrm{KI}$, Kamikubo $\mathrm{Y} /$ and Kato $\mathrm{H}$ (1997) A novel degradation pathway of tissue factro pathway inhibitor: Incorporation into fibrim clot an degradation by thrombin. Blood 90, 1883-92.

33. Nelsestuen GL, Broderius M and Martin G (1976) Role of gamma-carboxyglutamic acid. Cation specificity of prothrombin and factor Xuphospholipid binding. J Biol Chem 251, 688693.

34. Kazama $Y$ (1997) The importance of the binding of factor $X a$ to phospholipids in the inhibitory mechanism of tissue factor pathway inhibitor: The transmembrane and cytoplasmic domains of tissue factor are not essential for the inthibitory action of tissue factor pathway inhibitor. Thromb Haemost 77, 492-7.

35. Paborsky LR, Caras IW. Fisher KL and Gorman CM (1991) Lipid association, but not the transmembrane domain "is required for tissue factor activity. Substitution of the transmembrane domain with a phosphatidylinositol anchor. J Biol Chem 266, 21911-6.

36. Ruf W. Rehemtulla $\mathrm{A}_{*}$ Marrissey JH and Edgington TS (1991) Phospholipid independent and -dependent interactions required for tissue factor receptor and cofactor function. $\mathrm{J}$ Biol Chem 266, 2158-66.

37. Shigematsu $Y$, Miyata T. Higashi S, Miki T, Sadler JE and Iwanaga S (1992) Expression of human soluble tissue factor in yeast and enzymatic properties of its complex with factor Vlla. J Biol Chem 267, 21329-37.

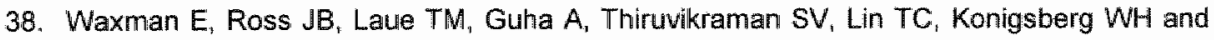
Nemerson $Y$ (1992) Tissue factor and its extracellular soluble domain: The relationship between intermolecular association with factor Vllia and enzymatic activity of the complex. Biochemistry $31,3998-4003$.

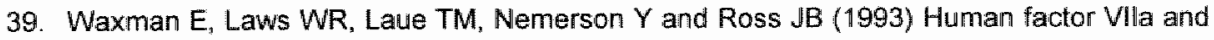
its complex with soluble tissue factor: Evaluation of asymmetry and conformational dynamics by ultracentrifugation and fluorescence anisotropy decay methods. Biochemistry 32, 3005-12.

40. Neuenschwander PF and Morrissey JH (1994) Roles of the membrane-interactive regions of factor VIla and tissue factor. The factor Vila Gla domain is dispensable for binding to tissue factor but important for activation of factor $X$. J Biol Chem 269, 8007-13.

41. Higashi $S$ and Iwanaga $S$ (1998) Molecular interaction between factor VII and tissue factor. Int J Hematol 67, 229-41.

42. Rao LVM and Pendurthi UR (1998) Tissue factor on cells. Blood Coag Fibrinol 9 Suppi 1 , S27-35.

43. Le DT, Rapaport SI and Rao LVM (1994) Studies of the mechanism for enhanced cell surface factor V/la/tissue factor activation of factor $X$ on fibroblast monolayers after their exposure to $\mathrm{N}$-ethyllmalleimide. Thromb Haemost $72,848-55$.

44. Bach $R$ and Rifkin DB (1990) Expression of tissue factor procoagulant activity: Regulation 
by cytosolic calcium. Proc Nati Acad Sci USA 87, 6995-9.

45. Greeno EW, Bach RR and Moldow CF (1996) Apoptosis is associated with increased cell sufface tissue factor procoagulant activity. Lab Invest $75,281-9$.

46. Bombeli T, Karsan A, Tait JF and Harlan JM (1997) Apoptotic wascular endothelial cells become procoagulant. Blood 89, 2429-42.

47. Davie EW, Fujikawa $K$ and Kisiel $W$ (1991) The coagulation cascade: Initiation, maintenance, and regulation. Biocthemistry 30, 10363-70.

48. Hansen JB. Huseby KR, Huseby NE, Ezban M and Nordoy A (1997) Tissue factor pathway inhibitor in complex with low densify lipoprotein isolated from human plasma does not possess anticoagulant function in tissue factor-induced coagulation in vitro. Thromb Res $85,413-25$.

49. Roubey RA (1998) Mechanisms of autoantibody-mediated thrombosis. Lupus 7, S114-9.

50. Roubey RA (1994) Autoantibodies to phospholipid-binding plasma proteins: A new view of lupus anticoagulants and other "antiphospholipid" autoantibodies. Blood 84, 2854-67.

51. Musial J. Swadzba J, Jankowski M Grzywacz M, Bazan-Socha S and Szczeklik A (1997) Thrombin generation measured ex vivo following microvascular injury is increased in SLE patients with antiphospholipid-protein antibodies. Thromb Haemost 78, 1173-7.

52. Cuadrado MJ, Lopez Pedrera $C_{*}$ Khamashta MA, Camps MT. Tinahones $F$, Torres $A$, Hughes $G R$ and Velasco $F$ (1997) Thrombosis in primary antiphospholipid syndrome: $A$ pivotal role for monocyte tissue factor expression. Arthritis Rheum 40, 834-41

53. Kormberg A, Blank $M$, Kaufman $S$ and Shoenfeld $Y$ (1994) Induction of tissue factor-like activity in monocytes by anti- cardiolipin antibodies. J Immunol 153, 1328-32

54. Williams FM, Jurd $K$, Hughes GR and Hunt BJ (1998) Antiphospholipid syndrome patients' monocytes are "primed" to express tissue factor. Thromb Haemost 80, 864-5.

55. Oosting JD, Derksen RH, Blokzij L, Sixma JJ and de Groot PG (1992) Antiphospholipid antibody positive sera enthance endothelial cell procoagulant activity: Studies in a thrombosis model. Thromb Haemost 68, 278-84.

56. Tanneribaum SH. Finko R and Cines DB (1986) Antibody and immune camplexes induce tissue factor production by human endothelial cells. $J$ Immunol $137,1532.7$. 


\section{Nederlandse Samenvatting}

Zoogdieren en andere hogere organismen zijn voor het transport van zuurstof en voedingsstoffen naar de diverse weefsels en organen en het afvoeren van de afvalproducten uitgerust met een bloedvatenstelsel. Om overmatig bloedverlies te voorkomen is het van levensbelang dat lekken in het vaatstelsel snel en efficiënt gedicht worden. Het bloedstollingmechanisme garandeert deze snelle respons en zorgt er tevens voor dat het reparatieproces beperkt blijft tot de plaats waar de schade is ontstaan. Het is immers ongewenst dat stolsels ontstaan op plaatsen anders dan daar waar de vaatschade is opgetreden. Een ongecontroleerde bloedstolling kan verstoppingen (trombose) tot gevolg hebben waardoor een tekort aan zuurstof ontstaat en afvalproducten zich ophopen hetgeen uiteindelijk kan leiden tot orgaan- en weefselschade. Het stollingsmechanisme moet dus uiterst nauwkeurig gereguleerd worden. 
Het bloedstollingsproces bestaal feitelijk uit twee gebeurtenissen. Als eerste hechter bloedplaatjes aan de vaatwand op de plaats van de beschadiging. De bloedplaatjes worden geactiveerd, plakken aan elkaar en vormen zo een primaire hemostatische plug. Vervolgens wordt een serie enzymatische reacties gestart (de stollingscascade) waardoor een fibrine netwerk ontstaat dat ervoor zorgt dat de primaire plug wordt verstevigd. De trigger voor het aanschakelen van de stollingscascade is het in contact komen van weefselfactor (tissue factor TF). geexposeerd op de plaats van de vaatwandbeschadiging, met het voorbij stromende bloed. De hierin aanwezigle stolfactor factor VII (een niet actief enzym) bindt aan de co-factor TF en wordt vervolgens geactiveerd tot factor VIlla (FVIlla, het actieve serine protease). Het TF:FVlla complex activeent op zijn beurt factor $X$ en factor $\mathrm{I} X$ die op hun beurt protrombine activeren tot trombine, het centrale enzym in de bloedstolling. Trombine zet vervolgens het oplosbare fibrinogeen om in onoplosbare fibrine draden.

Behalve de stolfactoren (zowel enzymen als co-factoren), is ook de aanwezigheid van fosfatidylserine (PS) van belang voor een goed verloop van de bloedstolling. PS is een negatief geladen fosfolipide dat aanwezig is in de buitenste laag van het membraan van geactiveerde bloedplaatjes. De negatieve lading van PS zorgt ervoor dat stolfactoren met een negatief geladen domein ( $F V I I, F I X, F X$, (pro)trombine en protein C) via een $\mathrm{Ca}^{{ }^{2+}}$ brug kunnen binden aan het membraanoppervlak. Binding van de stolfactoren aan het negatief geladen fosfolipiden oppervlak leidt tot een versnelling van de enzymatische reacties in de stollingscascade en zorgt er tegelijkertijd voor dat de enzymen en cofactoren geconcentreerd worden op de plaats van de vaatwandbeschadiging.

De remmer van het TF:FVlla complex, tissue factor pathway inhibitor (TFPI) wordt snel actief en verhinderd de verdere vorming van FIXa en FXa via deze route. De remming van TF:FVIla door TFPI gebeurt in twee stappen. Eerst bindt TFP\| aan FXa, waarbij de activiteit van FXa wordt geremd. Vervolgens bindt thet FXa:TFPI complex aan TF:FVIla. In het TF:FVlla:FXa:TFPI complex is de activiteit van FVlla volledig geremd. TFPI bestaat uit 276 aminozuren en heeft een zuur $N$-terminaal uiteinde, gevolgd door drie zogenoemde Kunitz domeinen en eindigt met een basische C-terminale staart. Het eerste Kunitz domein bindt FV/la en het tweede Kunitz domein bindt $\mathbb{F X a}$. De functie van het derde Kunitz domein is tot op heden onbekend. Van het positiel geladen C-terminale uiteinde wordt gedacht dat het een rol speelt bij het binden van TFPI en FXa:TFPI aan PS.

Het doel van de studies beschreven in dit proefschrift was het onderzoeken van de bijdrage van PS aan de remmende activiteit van TFPI ten opzichte van TF:FVlla gekatalyseerde $F X$ activering. Onze hypothese is dat het $C$-terminale uiteinde van TFPI hierbij een belangrijke rol speelt. Om dit te onderzoeken hebben we gebruik gemaakt van neutrale en negatief geladen fosfolipiden oppervlakken 
bestaande uit respectievelijk fosfatidylcholine (PC) en $75 \mathrm{~mol} \%$ fosfatidylcholine/ 25 mol\% fosfatidylserine (PSPC) met daarin eventueel TF aanwezig. Tevens werd gebruik gemaakt van twee vormen van TFPI, het intacte TFPI (TFP |FL) en TFP\| dat het derde Kunitz domein inclusief de positief geladen staart mist (TFPI $\left.\right|_{-161}$ ).

Omdat alleen kwalitatieve data beschikbaar waren over de binding van $\mathrm{FXa}$, TFPI en FXa:TFPI aan PSPC membranen, zijn we gestart met het kwantitatief beschrijven van de binding van deze eiwitten en eiwitcomplexen aan PSPC oppervlakken. Hierbij werd gebruik gemaakt van ellipsometrie, een techniek waarmee de hoeveelheid geadsorbeerd eiwit op een oppervlak kan worden bepaald. Uit hoofdstuk 2 blijkt dat FXa:TFPIFL complexen met een hoge affiniteit $(\mathrm{Kd}=5.5 \mathrm{nM})$ binden aan PSPC oppervlakken. FXa:TFP| $\left.\right|_{1-16 t}$ complexen daarentegen binden met een veel lagere affiniteit, die in feite niet veel verschilt van de affiniteit van $\mathrm{FXa}$ alleen ( $\mathrm{Kd}=42 \mathrm{nM}$ ). De hogere affiniteit van FXa:TFPIFL is dus afhankelijk van de aanwezigheid van het derde Kunitz domein en de positief geladen $\mathrm{C}$-terminale staart. Opmerkelijk is dat TFPI $\mathrm{FL}_{\mathrm{L}}$ zonder $\mathrm{FXa}$ bijna niet bindt aan PSPC $(\mathrm{Kd}=5 \mu \mathrm{M})$ maar in complex met FXa de binding van FXa aan PSPC blijkt te stimuleren. Onze metingen suggereren dat in het FXa:TFPlFL complex zowel FXa (via zijn negatief geladen domein d.m.v. een $\mathrm{Ca}^{2+}$ brug) als TFPl FL (via de positief geladen C-terminale staart) een interactie aangaan met het fosfolipidenoppervlak. Deze suggestie wordt ondersteund door de observatie dat wanneer $\mathrm{FXa}$ in overmaat aanwezig is ten opzichte van TFP $\mathrm{FL}_{\mathrm{L}}$, de FXa:TFPl FL complexen langzaam desorberen van het PSPC oppervlak. Het bleek dat TFPl FL werd geknipt door FXa tussen de aminozuren $\mathrm{Arg}^{199}$ en $\mathrm{Ala}^{200}$. Door deze knip veranderd waarschijnlijk de oriëntatie van de C-terminale staart (die overigens wel vast blijft zitten aan de rest van TFPI door de zwavelbrugverbindingen in het derde Kunitz domein) waardoor het FXa:TFPIFL, complex zijn hoge affiniteit voor PSPC verliest.

In hoofdstuk 3 wordt het knippen van TFPI $F$ door $F X a$ en het effect daarvan op de remmende werking van TFPl FL beschreven. Het knippen van de $\mathrm{Arg}^{199}{ }^{19}-\mathrm{Ala}^{200}$ binding resulteerde in een dramatisch gereduceerde anti-stollende werking van TFPI in plasma. In een gezuiverd systeem, echter, leek het knippen van $\operatorname{Arg}^{199}$ $\mathrm{Ala}^{200}$ geen effect te hebben op de remmende werking van TFPI ten aanzien van TF:FVIla gekatalyseerde FXa vorming. Tevens werd een tweede knipplaats in TFPI geïdentificeerd, namelijk tussen de aminozuren $\mathrm{Lys}^{86}$ en $\mathrm{Th}^{87}$. Deze knip resulteerde zowel in plasma als in een gezuiverd systeem in een totaal verlies van de remmende werking van TFPI. Dit is niet zo verwonderlijk omdat deze knip zorgt voor de dissociatie van het eerste (FVIla bindende) en tweede (FXa bindende) Kunitz domein, die beide nodig zijn voor de werking van TFPI. Of deze knippen in TFPI doar FXa ook in vivo plaatsvinden is nog onbekend. Dat binding aan fosfolipiden belangrijk zou kunnen zijn voor de remmende werking van FXa:TFPI 
wordt besproken hoofdstuk 4 . De remming van de activering van $\mathrm{FX}$ werd gemeten op neutrale en negatiel geladen fosfolipidenoppervlakken die TF bevatten (respectievelijk aangeduid met TF:PC en TF:PSPC). Om de in vivo situatie zoveel mogelijk na te bootsen werden de reactanten aan het oppervlak aangeboden onder stromende condities. OP TF:PC oppervlakken was er voor de remming van TF:FVlla gekatalyseerde $F X$ activering geen verschil te zien tussen $F X a: T F P I_{F L}$ en FXa:TFPl ${ }_{1-181}\left(2^{\mathrm{e}}\right.$ orde remmingconstanten waren respectievelijk $0.07 \times 10^{8} \mathrm{M}^{-1} \mathrm{~s}^{-1}$ en $0.1 \times 10^{8} \mathrm{M}^{-1} \mathrm{~s}^{-1}$ ). Op TF:PSPC waren de verschillen tussen beide remmers veel groter, de remmingconstanten voor FXa:TFPIFL en FXa:TFP| $\left.\right|_{1.161}$ waren respectievelijk $0.20 \times 10^{8} \mathrm{M}^{-1} \mathrm{~s}^{-1}$ en $0.94 \times 10^{8} \mathrm{M}^{-1} \mathrm{~s}^{-1}$. De aanwezigheid van PS stimuleerde dus de werking van beide FXa:TFPI complexen maar FXa:TFPI ${ }_{1-161}$ wordt meer gestimuleerd dan FXa:TFPI FL. Dit is opmerkelijk omdat FXa:TFP| $\left.\right|_{F L}$ een grotere affiniteit heeft voor PSPC oppervlakken (hoofdstuk 2). Dit leidde tot de hypothese dat juist door deze hoge affiniteit, FXa:TFPlFL massaal bindt aan de PSPC membraan waardoor er minder FXa:TFPI $F \mathrm{~L}$ in de oplossing aanwezig is met als gevolg, een schijnbare verminderde remming van de TF:FVlla aktiviteit. Echter, FXa:TFPIFL gebonden aan PSPC bleek niet verloren te zijn voor zijn remmende werking. Dit volgde uit de waarneming dat wanneer TF:PSPC werd gepreïncubeerd met FXa:TFPl FL en het ongebonden FXa:TFPlFL werd weggewassen, een sterk geremde FXa vorming werd gemeten na het toevoegen van FVIla en FX (vooral de initiele snelheid van $F X a$ vorming werd geremd). Dit effect werd niet waargenomen wanneer TF:PSPC werd gepreïncubeerd met FXa:TFP| $\left.\right|_{1-161}$. Dat het in deze experimenten daadwerkelijk om PSPC gebonden FXa:TFPI $F$ ging en niet om FXa:TFPl $F L$ gebonden aan TF, bewezen de proeven met TF:PC oppervlakken. Daarin werd geen enkel remmend effect op de FX activering gemeten nadat TF:PC was geincubeerd met $F X a: T F P I_{F L}$.

Dat FXa:TFPl $F_{\text {Ll }}$ niet alleen aan negatief geladen kunstmatige fosfolipidenoppervlakken (PSPC) bindt, maar ook aan PS bevattende fibroblastplasmamembranen werd aangetoond in hoofdstuk 5. Ook het fibroblast gebonden FXa:TFPI $I_{F L}$ bleek nog steeds actief als remmer van de TF:FVlla katalytische

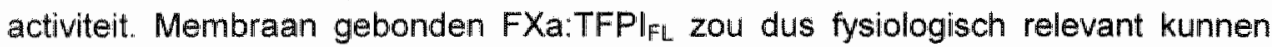
zijn in het reguleren van de TF:FVlla route door het remmen van, aan het celoppervlak, nieuw gevormd TF. Cellen die TF tot expressie brengen en een geprogrammeerde celdood (apoptosis) ondergaan hebben een toegenomen hoeveelheid PS in hun buitenmembraan en vertonen een verhoogde TF:FVlla activiteit. Ook in dat geval zou celgebonden FXa:TFPI $\left.\right|_{F L}$ een effectieve regulator kunnen zij van de TF:FVlla activiteit.

Uit het voorgaande blijkt dat PS een dubbelrol speelt in de TF:FVlla afhankelijke activering van FX omdat zowel de pro-coagulante activiteit van TF:VIla kan worden gestimuleerd als wel de anti-stollende werking van FXa:TFPI. 
Componenten met een hoge affiniteit voor PS kunnen dus door competitie met de stollingseiwitten voor dezelfde membraan bindingsplaatsen zowell de pro als antistollende reacties beïnvloeden. Een pathologische conditie waarbij dit scenario zich zou kunnen voltrekken is het anti-fosfolipidensyndroom of het syndroom van Hughes. Patiënten met dit syndroom hebben antilichamen tegen fosfolipidenbindende eiwitten en de gevormde antilichaam-antigeen complexen hebben een hoge affiniteit voor binding aan PS. In vitro stoltesten lieten zien dat de plasma's van deze patiënten een verlengde stoltijd hadden. Dit is echter niet in overeenstemming met de trombotische complicaties (zoals herhaalde spontane abortussen, arteriële en veneuze trombose, trombocytopenie) die deze patiënten ondervinden. Daarom suggereerden wij dat anti-fosfolipiden antilichamen interfereren met de remmende activiteit van FXa:TFPI. Dit zou dan kunnen resulteren in een toegenomen $\mathrm{FXa}$ en trombine generatie. Aanwijzingen hiervoor zijn inderdaad gevonden zoals wordt beschreven in hoofdstuk 6. De TF:FVlla gekatalyseerde $\mathrm{FXa}$ vorming in plasma van patiënten met het syndroom van Hughes bleek te zijn verhoogd ten opzichte van controle plasma. Deze toegenomen FXa vorming was afhankelijk van de aanwezigheid van TFPI en het negatief geladen fosfolipide PS. Het toevoegen van totaal-lgG, geissoleerd uit patièntenplasma, aan controle plasma resulteerde eveneens in een verhoogde $F X_{a}$ generatie. Zoals aangetoond was anti $\beta_{2}$-glycoprotein I IgG in complex met $\beta_{2}-\mathrm{GPI}$ verantwoordelijk voor deze verhoogde $F X a$ vorming. De toename in FXa generatie na het toevoegen van anti $\beta_{2}-G P I$ aan normaal plasma lleidde niet tot een verhoogde trombine generatie. Wanneer exogeen TFPI $(5 \mathrm{nM})$ werd toegevoegd aan normaal plasma dan resulteerde dat in een sterke remming (20-voudig) van de FXa en trombine generatie, die echter kon worden gereduceerd tot een slechts 4voudige remming wanneer ook anti- $\beta_{2}$-GPI werd toegevoegd. De remmende werking van TFPI ( $5 \mathrm{nM}$ ) kon niet volledig worden opgeheven door het toevoegen van anti $\beta_{2}$-GPI. Ondanks dat $5 \mathrm{nM}$ TFPI meer is dan de normaal in plasma aanwezige hoeveelheid $(0.2 \mathrm{nM})$, moet niet uit het oog verloren worden dat er een enorm reservoir bestaat van TFPI op het endotheel in de vaatwand. Dit kan betekenen dat er lokaal hoge concentraties TFPI beschikbaar kunnen zijn op de plaats waar bloedstolling plaats vind. Het mogelijke effect van anti-fosfolipiden antilichamen op de remmende werking van TFPI kan duiden op een heel nieuw mechanisme dat zou kunnen verklaren waarom mensen met het syndroom van Hughes leiden aan trombotische complicaties. 


\section{Dankwoord}

Van Haren naar Maastricht doe ik er rum vier uur over met de trein. Tijd genoeg om het dankwoord te schrijven zou je denken. Helaas gooide een wisselstoring roet in het eten. Ik moest een andere route nemen, daardoor vaker overstappen en het gevolg was dat er vam die eerste poging helemaal niets terechtgekomen is. Het is bijna te vergelijken met promoveren. Bijna, want in tegenstelling tot eerder genoemde reis, is die promotie niet op een dood spoor geëindigd en zonder vertraging verlopen. Maar net zo goed als niet alleen de machinist verantwoordelijk is voor een goed verloop van de dienstregelling, is ook het voltooien vam het promotieonderzoek niet alleen mijn verdienste geweest. De afgelopen vier jaar hebben perronchefs, seinwachters, medepassagiers, conducteurs en misschien een enkele zwartrijder ertoe bijgedragen dat deze rit tot een goed einde werd gebracht. En die personen wil ik daavoor op deze plaats bedanken.

In de eerste plaats mijn begeleiders Theo Lindhout en George Willems. Theo, ik heb altijd met heel veel plezier met je samengewerkt, ook al lag je wel eens dwars in het waterbad (of daarbuiten). Jouw enthousiasme en gedrevenheid, je praktische kijk op zaken, kennis van de kinetiek en je brede belangstelling maakten onze discussies altijd erg levendig. Ikk heb heel veel van je gelleerd, ook dat ik eers! moet nadenken over wat ik nu eigenlijk bedoel voor ik lets zeg of opschrijf. Je hebt me altijd veel vrijheid gegeven en je stelde het volste vertrouwen in me, dat waardeer ik enorm. Dat je ook oog had voor zaken buiten de wetenschap, en tijd vrij maakte om te zeilen, voor 'n lab-uitje, te BBQen en voor een persoonlijk gesprek, heeft veel waardevolle momenten opgeleverd. George, jouw bijdrage is minstens van even groot belang geweest voor het onderzoek en de totstandkoming van dit proefschrift. Veel van wat we tegenwoordig niet meer op school leren heb jij me met veel geduld uitgelegd. Jouw kritische beoordelingen van de manuscripten hebben mij niet alleen vaak veel werk gekost maar ook heel veel geleerd over helder formulteren. Met veel plezier denk ik terug aan onze werkdiscussies die, soms na veel ge-welles / -nietes, altijd wel in een idee of voorstel eindigden.

Professor Hemker, u wil ik bedanken voor het mij in die gelegenheid stellen in uw groep te werken en voor de belangstelling waar ik altijd op kon rekenen.

Als promovendus kun je niet alles en ook niet alles alleen en daarom wil ik ook de volgende personen bedanken. Jo en Simone bedankt voor jullie technische en morele ondersteuning. Jo, radio Maastricht is echt vreselijk, maar jouw bisschopswijn is onovertroffen, je ziet er zelfs de zon van opkomen! Didier, merci pour mintroducer dans le monde du "fflow". Ron, ik had je dit liever persoonlijk gezegd, maar het is allemaal heel anders gelopen. Je was een toffe collega en ik zal die eeuwige grijns 
van je altijd blijven herinneren, net als de koffie, de trombine generatie metingen en Marillion op de achtergrond. Het is knap waardeloos dat je er niet meer bent, life is a bitch.

De buren! Wat had ik gemoeten zonder jullie? Stella, Joyce, Lico, Gerry, Guido, Kristin. Tilman, Rob, Jose en Jan. Bij jullie kon ik echt voor alles terecht: gel-bakjes, CD-tjes, lunch, advies, slap geouwehoer, bier, melkpoeder, darten, goede raad (ook ongevraagd) en een luisterend oor, om maar eens wat te noemen.

Van wie kun je beter leren fibroblasten kweken dan van iemand die bier brouwt en cellen kweekt zonder gistinfecties? Rein, bedankt (ook voor de krant en de afleiding). Chris, Cecile, Petra, Waander, Heidi, Nico, Harold en Hanneke bedankt dat ik zo ongestoord mijn gang kon gaan op het lab en in de flowkast, ook al was het wel eens spitsuur. I zal die gezellige chaos missen.

Trees bedankt voor al je moederlijke adviezen over..............ach je weet wel!

Verder wil ik alle andere collega's en oud-collega's van de vakgroep Biochemie bedanken voor de fijne tijd op de afdeling en daarbuiten. Of het nu bij de koffie, het dagje uit, de werkbesprekingen, in Washington, tijdens 'n AIO cursus, in de Kadlans, Houthalen of achter een Choufke was, ik kijk er met veel plezier op terug!

Inmiddels heb ik Biochemie verruild voor "The King's society" in Haren en ook mijn nieuwe collega's wil ik bij deze bedanken voor hun belangstelling "begrip en morele steun tijdens het afronden van dit proefschrift. Met name de MDR groep: Wil, Robbert, Marloes, Rik, Monique, Marjon bedankt, arie-ngatoo Kanta , dzie, kuje, bardzo Piotr and Sylwia, muchas gracias Avalardo.

Ine en Joyce, mijn paranimfen, jullie (samen met Michel en Spike) wil ik bedanken voor alle steun en de bijzondere vriendschap. Nog twee powervrouwen die ik wil bedanken Rineke en Carlien. Ik ga geen anekdotes aanhalen, anders wordt het een dankwoord voor 16 jaar en ouder, maar ik ben heel blij dat jullie er altijd voor me waren en zijn. Lisbeth, jij bent een verhaal apart, kitschkoningin en macha, je bent mijn grote voorbeeld. Fran (en Ruud) en Ingrid (en Theo) bedankt dat ik nog steeds mee mag doen, volgend jaar zorg ik dat mijn conditie op peil is.

Pap en Mam, bedankt voor jullie onvoorwaardelijke steun en het vertrouwen dat het allemaal wel goed komt. Ik ga niet altijd voor de makkelijkste of meest begrijpelijke weg maar jullie hebben mijn keuzes altijd gerespecteerd en daar ben ik jullie heel dankbaar voor. Yvon, je vind het allemaal heel wat dat studeren en promoveren, maar ik ben er trots op dat jij mijn zusje bent.

Lieve Jacco, ik zou je tekort doen als ik je hier zou bedanken voor je steun en hulp de afgelopen maanden. Jij betekent immers zoveel meer voor mij, dat laat zich niet in een dankjewel vatten. Poppea's hartenkreet "Tu sei pur L'idol mio. Si, mio ben, $\mathrm{Si}$, mio cor, mia vita, si" komt iets dichter in de buurt. 


\section{List of Publications}

1. E-Crystallin is more thermostable than mammalian argininosuccinate lyase.

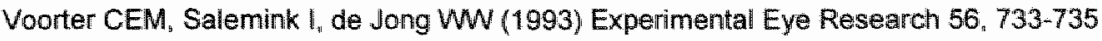

2. Induction of non-bilayer structures in diacylphosphatidylcholine model membranes by transmembrane $\alpha$-helical peptides: importance of hydrophobic mismatch and proposed role of tryptophans.

Killian JA, Sallemink I, de Planque MRR, Lindblom G, Koeppe RE, Greathouse DV (1996) Biochemistry 35, 1037-1045

3. Tissue factor pathway inhibitor regulation of its inhibitory activity by phospholipid surfaces. Lindhout T, Salemink I, Valentin S, Willems GM (1996) Haemostasis 26 (Suppl 4), 89-97

4. Prothrombinase is protected from inactivation by tissue factor pathway inhibitor: competition between prothrombin and inhibitor.

Franssen J, Salemink I, Willems GM, Wun TC, Hemker HC, Lindhout T (1997) Blochemical Journal $323,33-37$

5. Transient high affinity binding of tissue factor pathway inhibitor-factor Xa complexes to negatively charged phospholipid membranes.

Willems GM, Janssen MP, Salemink I, Wun TC, Lindhout T (1998) Biochemistry 37, 3321-3328

6. Factor Xa cleavage of tissue factor pathway inhibitor is associated with loss of anticoagulant activity.

Salemink I, Franssen J, Willems GM, Hemker HC, Li A, Wun TC, Lindhout T (1998) Thrombosis and Haemostasis $80,273-280$

7. Inhibition of tissue factor factor Villa-catalyzed factor $X$ activation by factor Xa:tissue factor pathway inhibitor.

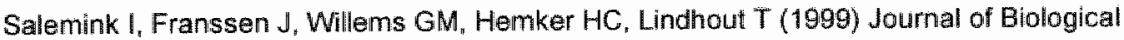

Chemistry $274,28225-28232$

8. Tissue factorfactor Vlla catalyzed factor $X$ activation and its inhibition by factor Xa:tissue factor pathway inhibitor at human embryonic lung fibroblasts adhered to a rotating disc.

Salemink I. Willems GM. Briedé Jل, Hemker HC, Lindhout T (1999) submitted

9. Antibodies to $\beta_{2}$-glycoprotein I from patients with antiphospholipid syndrome suppress the inhibitory activity of tissue factor pathway inhibitor.

Salemink I, Blezer R, Willerns GM, Galli M, Bevers E, Lindhout T (1999) submitted 


\section{Curriculum Vitae}

De auteur van dit proefschrift werd geboren op 27 juni 1970 te Rotterdam. Op tweejarige leeftijd werd deze metropool verruild voor een gehucht, gelegen ergens op het Limburgse platteland, genaamd Ell. Het is hier dat de basis voor de zachte $\mathrm{g}$ werd gelegd. In 1988 behaalde Irene het HAVO diploma aan de Philipis van Horne scholengemeenschap te Weert. In datzelfde jaar begon ze aan de Hogeschool Heerlen, afdeling hoger laboratorium onderwijs, toen nog gevestigd te Sittard "met de opleiding tot biochemisch analist. Deze studie werd afgerond met een stage aan de Katholieke Universiteit Nijmegen bij de vakgroep Biochemie/Centrum voor oog onderzoek. In de groep van Prof. Dr. W.W. de Jong werd onder de enthousiaste leiding van $\operatorname{Dr}$ C.E.M. Voorter onderzoek verricht naar de stabiliteit van de ooglenseiwitten $\varepsilon, \tau$ en $\delta$ crystalline. Irene vervolgde in 1992, na het behalen van het HLO diploma haar opleiding met de verkortte studie Scheikunde aan de Universiteit Utrecht. Het hoofdvak werd doorlopen bij het Centrum voor Biomembranen en Lipide Enzymologie (CBLE), vakgroep Biochemie onder leiding van Prof. Dr. B de Kruijff. Onder de bezielende leiding van Dr. J.A. Killian werd van januari tot en met december 1994 onderzoek gedaan naar het effect van hydrofobic mismatch. Aansluitend daarop werd aan de Arhus Universitet (Denemarken), voor een periode van 6 maanden, onderzoek verricht naar Initiatie Factor-2 uit Corynebacterium glutamicum, onder supervisie van Dr. H.U. Sperling Petersen en K. Kusk Mortensen (Faculteit der Natuurwetenschappen, vakgroep Biochemie, afdeling Biostructurele Scheikunde o.I.v. Prof. Dr. B.F.C. Clark). Met het doctoraal diploma Scheikunde op zak werd 1 september 1995 begonnen als onderzoeker in opleiding bij het Cardiovasculair Research Instituut Maastricht (CARIM), vakgroep Biochemie o.l.v. Prof. Dr. H.C. Hemker. De copromotoren Dr. T. Lindhout en Dr. G.M. Willems zagen erop toe dat het onderzoek naar de regulatie van factor $\mathrm{Xa}$ generatie op weefselfactor bevattende oppervlakken resulteerde in het proefschrift dat nu voor $u$ ligt. Sinds 1 september 1999 is Irene werkzaam als postdoc in de vakgroep Moleculaire Microbiologie, onderdeel van the Groningen Biomolecular Sciences and Biotechnology Institute (GBB), Rijksuniversiteit Groningen. Ze houdt zich bezig met de rol van multidrug resistance related protein 1 in multidrug resistentie. 